Andrews University

Digital Commons @ Andrews University

\title{
Ethical Analysis Of Abuses Of Power In Christian Leadership - A Case Study Of "Kingly Power" In The Seventh-day Adventist Church
}

Zorislav Plantak

Andrews University, zplantak@andrews.edu

Follow this and additional works at: https://digitalcommons.andrews.edu/dissertations

Part of the Religious Thought, Theology and Philosophy of Religion Commons

\section{Recommended Citation}

Plantak, Zorislav, "Ethical Analysis Of Abuses Of Power In Christian Leadership - A Case Study Of "Kingly Power" In The Seventh-day Adventist Church" (2017). Dissertations. 1646.

https://digitalcommons.andrews.edu/dissertations/1646

https://dx.doi.org/10.32597/dissertations/1646

This Dissertation is brought to you for free and open access by the Graduate Research at Digital Commons @ Andrews University. It has been accepted for inclusion in Dissertations by an authorized administrator of Digital Commons@ Andrews University. For more information, please contact repository@andrews.edu. 


\section{ABSTRACT}

\section{ETHICAL ANALYSIS OF ABUSES OF POWER IN CHRISTIAN LEADERSHIP - A CASE STUDY OF "KINGLY POWER" IN THE SEVENTH-DAY ADVENTIST CHURCH}

\section{by}

Zorislav Plantak

Adviser: Denis Fortin, Ph.D. 


\title{
ABSTRACT OF GRADUATE STUDENT RESEARCH
}

\author{
Dissertation
}

Andrews University

Seventh-day Adventist Theological Seminary

\section{Title: ETHICAL ANALYSIS OF ABUSES OF POWER IN CHRISTIAN LEADERSHIP-A CASE STUDY OF “KINGLY POWER" IN THE SEVENTH-DAY ADVENTIST CHURCH}

Name of Researcher: Zorislav Plantak

Name and Degree of Faculty Advisor: Denis Fortin, Ph.D.

Date Completed: December 2017

\section{Problem and Purpose}

Power is an integral aspect of all types of leadership. The term "abuse of power" describes an inappropriate and corrupt application of power. The exercise of power becomes an abuse of power when a person in a position of power acts in a manner that cannot be justified in terms of truth or morality (goodness, kindness, justice, or obedience). While abuses of power have always been a part of Christian leadership, including the Seventh-day Adventist Church leadership, no scholarly study on the moral dimensions of abuses of power in the Adventist Church has been done. Although such abuses are well known, without an ethical analysis of these experiences important lessons of how Christian leaders might deal with the corruptive nature of power cannot be 
learned. An analysis of the misuse of power is a necessary first step to learn how to avoid the traps of power abuse and to find possible solutions for enhancing Christian leadership.

\section{Methodology}

The ethical analysis in this study concentrated on only one aspect of leadershipthe misuse of power. Since the abuse of power is a deviation from true Christian leadership and morally inappropriate, the ethical analysis did not include typical moral dilemmas such as discerning between good and bad, or right and wrong. Instead, the analysis in this study searched for the causes of the abuses of power.

As a case study, this study investigates the "kingly power" incident in the Seventh-day Adventist Church, which took place in the late $19^{\text {th }}$ and early $20^{\text {th }}$ centuries and analyses the leadership of two prominent leaders involved in the controversy, John Harvey Kellogg, leader of the medical branch of the Seventh-day Adventist Church and Arthur Grosvenor Daniells, leader of the ministerial branch and president of the General Conference of the Seventh-day Adventists.

Based on its causes, this research categorizes the abuse of power in the following seven groups: abuses related to misuse of authority, to mistreatment of subordinates, to preservation of power, to misconduct of a leader, to corrupted character traits, to ignoring Christian principles, and to misplaced responsibility, authenticity and presence.

\section{Conclusions}

The analysis of the abuses of power is followed by some proposed measures for their prevention. Preclusion starts with the awareness that spiritual leaders are servants of God who are in service to His people. It requires transparency and well defined and 
limited mandate of the leader. Additionally, subordinates and leaders are supposed to act as checks and balances for each other. Leaders must be reminded that they are not irreplaceable. Practical solutions for the problem would include limiting a leader's time in office, mandating changes or rotations in the leadership position, clearly defining the boundaries and limits of a particular position, and educating leaders regarding the extent and limitations of their position. Consequently, sharing responsibility, empowering the whole body of the church, and making decisions through committees have the purpose of shifting power from the hands of the individual to the whole church. The purpose of the election process is to elect a leader with the clear principles, one which practice them, and one that has the least amount of vices, since no one is perfect.

While the Seventh-day Adventist Church attempted to deal with the abuses in its leadership by implementing changes in organizational structure, the discrepancy between Christocentric theory and abusive practice proves that abuses of power depend on the personal conduct of the leader and on how much his subordinates allow that leader to exercise such inordinate power. The steps suggested in this study are a simple attempt to propose some potential solutions, with the goal of starting a constructive discussion of practical steps to prevent power abuse. 
Andrews University

Seventh-day Adventist Theological Seminary

\title{
ETHICAL ANALYSIS OF ABUSES OF POWER IN CHRISTIAN LEADERSHIP - A CASE STUDY OF "KINGLY POWER" IN THE SEVENTH-DAY ADVENTIST CHURCH
}

\author{
A Dissertation \\ Presented in Partial Fulfillment \\ of the Requirements for the Degree \\ Doctor of Philosophy
}

by

Zorislav Plantak

December 2017 
(C) Copyright by Zorislav Plantak 2017

All Rights Reserved 


\title{
ETHICAL ANALYSIS OF ABUSES OF POWER IN CHRISTIAN LEADERSHIP - A CASE STUDY OF "KINGLY POWER" IN THE SEVENTH-DAY ADVENTIST CHURCH
}

\author{
A dissertation \\ presented in partial fulfillment \\ of the requirements for the degree \\ Doctor of Philosophy
}

by

Zorislav Plantak

\section{APPROVAL BY THE COMMITTEE:}

Faculty Adviser,

Denis Fortin

Professor of Historical Theology

Darius Jankiewicz

Professor of Historical Theology

Jo Ann Davidson

Professor of Theology

Stanley Patterson

Professor of Christian Ministry

William Knott, $\mathrm{PhD}$

Editor \& Executive Publisher of Adventist Review \& Adventist World

Adjunct Professor, Andrews University
Director of $\mathrm{Ph} . \mathrm{D} / \mathrm{Th} . \mathrm{D}$ Religion Programs

Thomas Shepherd

Dean, SDA Theological Seminary

Jiř́ Moskala
Date approved 


\section{TABLE OF CONTENTS}

LIST OF ABBREVIATIONS ................................................................... vi

ACKNOWLEDGMENTS _............................................................................... vii

Chapter

1. INTRODUCTION ...............................................................................

Concept of Power ……………………………………………....... 2

Power and Authority ......................................................................... 7

The Problem of Power Abuse ................................................................. 9

The Case for Study ............................................................................. 16

Statement of the Problem .................................................................... 19

Purpose and Justification................................................................... 20

Scope and Delimitations................................................................. 21

Methodology and Outline.................................................................... 21

2. THEORETICAL FRAMEWORK FOR AN ETHICAL ANALYSIS OF THE ABUSE OF POWER IN CHRISTIAN LEADERSHIP ................. 24

Biblical Background for the Ethics of Power........................................ 26

Power of God ........................................................................ 30

Power of Human Beings - Power Received from God................... 36

Jesus as Example - Powerless Power ............................................. 43

Summary ..................................................................... 50

Ethics of Using Power ..................................................................... 51

Ethical Theories of Leadership ................................................... 52

Theories About the Conduct of a Leader ................................. 52

Theories About the Character of a Leader ............................... 55

Principle-centered Leadership .............................................. 58

Components of Ethical Leadership ............................................... 60

Responsibility ………................................................... 60

Authenticity................................................................... 61

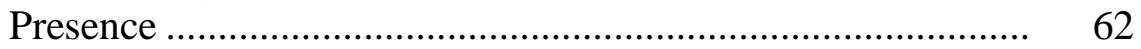

Perspectives on Ethical Leadership................................................ 63

Servant Leadership ............................................................. 65

Summary …….................................................................. 69

The Christian Model of Leadership ....................................................... 71

Unique Standards of Christian Ethics ............................................ 72

The Christian Servant Leadership Model ........................................ 73 


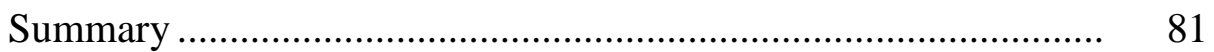

The Pattern for Analysis of Abuses of Power ...................................... $\quad 82$

Two Paradigms of the Use of Power............................................. 82

The Basis of the Pattern ................................................................. 88

The Pattern ............................................................................ 90

3. THE ISSUE OF KINGLY POWER IN THE ADVENTIST CHURCH....... 93

The Kingly Power Controversy............................................................... 93

Historical Context ...................................................................... 93

Emergence of the Issue of Kingly Power......................................... 97

Excessive Power of the Leaders of the Church ...................... 101

Centralization of Power and Activities in One Location ......... 103

Short Biography of Two Leaders ................................................. 106

John Harvey Kellogg .......................................................... 106

Arthur Grosvenor Daniells....................................................... 109

The Relationship between Kellogg and Daniells..................... 111

The Socio-political Context of the Issue of Kingly Power ............ 119

The Larger Context of an Interaction of Christian

Leadership with the Society and Politics .......................... 119

The Times of Kellogg and Daniells ........................................ 122

Theodore Roosevelt - "the elected king" ................................ 126

Summary …............................................................................... 133

The Seventh-day Adventist Doctrine of the Church ............................. 134

Theological Foundation of the Doctrine of the Church ................. 135

The Organization of the Church...................................................... 139

Historical Context of the Development of the Church

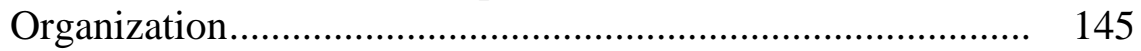

Summary ……..................................................................... 153

Response of the Church to the Issue of Kingly Power:

Reorganization of the Church During the 1901 and 1903

Sessions of the GC .................................................................. 154

The Main Issue at the 1901 Session of the GC .............................. 157

Measures Taken During the 1901 Session .................................... 159

The Period between the Two Sessions............................................. 162

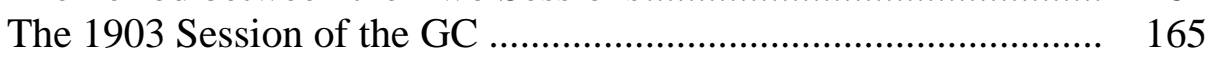

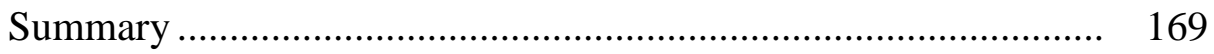

Conclusion.......................................................................... 170

4. ETHICAL ANALYSIS OF ABUSES OF POWER ………………............... 173

Seven Types of Abuses of Power......................................................... 175

Abuses Related to Misuse of Authority ....................................... 176

Basic Premise ................................................................. 176

Pattern for Analysis........................................................... 176

Analysis.......................................................................... 176

Lessons Learned.............................................................. 186 
Abuses Related to Mistreatment of Subordinates ........................ 188

Basic Premise ..................................................................... 189

Pattern for Analysis.......................................................... 189

Analysis........................................................................ 189

Lessons Learned.............................................................. 197

Abuses Related to Preservation of Power ................................. 198

Basic Premise ................................................................... 198

Pattern for Analysis......................................................... 199

Analysis......................................................................... 199

Lessons Learned................................................................ 209

Abuses Related to the Misconduct of a Leader............................ 211

Basic Premise ................................................................... 211

Pattern for Analysis.......................................................... 211

Analysis........................................................................ 212

Lessons Learned............................................................. 217

Abuses Related to Corrupted Character Traits............................ 218

Basic Premise ................................................................... 218

Pattern for Analysis........................................................ 219

Analysis........................................................................ 219

Lessons Learned............................................................. 225

Abuses Related to Ignoring Christian Principles ......................... 225

Basic Premise ................................................................. 225

Pattern for Analysis....................................................... 226

Analysis........................................................................ 226

Lessons Learned............................................................. 228

Abuses Related to Misplaced Responsibility, Authenticity and

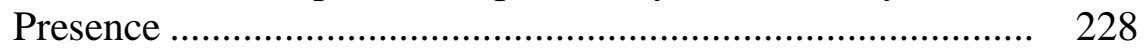

Basic Premise ............................................................. 228

Pattern for Analysis....................................................... 229

Analysis................................................................. 229

Lessons Learned................................................................ 234

Abuses of Power in Light of the Principles of Christian Servant

Leadership ..................................................................... 235

5. SUMMARY AND CONCLUSIONS ............................................... 241

The Challenge of Being a Christian Servant Leader......................... 241

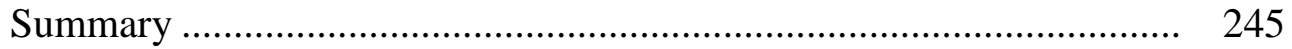

Some Final Suggestions ........................................................ 257

BIBLIOGRAPHY ........................................................................... 264

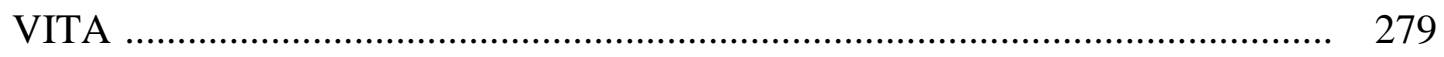




\section{LIST OF ABBREVIATIONS}

$\begin{array}{ll}\text { GC } & \text { General Conference } \\ \text { KJV } & \text { King James Version } \\ \text { NIV } & \text { New International Version } \\ \text { NKJ } & \text { New King James } \\ \text { NT } & \text { New Testament }\end{array}$




\section{ACKNOWLEDGMENTS}

The biggest human achievements are usually the result of the contributions of many. This study is not an exception. While people will associate this study with the name of the author, I do not want to forget the significant involvement of others.

I am very thankful to Dr. Miroslav Kiš who encouraged me to start this journey and under whose guidance the ideas for this study were developed. His support and encouragement were interrupted prematurely by his untimely death. Thus, this study was not a sprint but rather a marathon. My deepest gratitude goes to my second advisor Dr. Denis Fortin for his willingness to help me to continue this "race" at the most critical moments and supported me all the way to the end. I am thankful for his patience, prompt and helpful feedback. His insightful comments significantly improved the quality of this dissertation.

I would like to express my thankfulness also to the other members of my committee, Dr. Jo Ann Davidson, and Dr. Darius Jankiewicz, who also played important roles in the completion of this document. I am thankful to Dr. Thomas Shephard and all other directors of Ph.D. in Religion and Th.D. Programs for their prayers, moral support, solving the problems but also financial support.

While the James White Library, including the Center for Adventist Research, was a source of information, I am thankful to the library and my supervisor Josip Horonic for a work opportunity during the years of my study. I cannot skip mentioning the important 
help of Culture System Inc. which provided me also with employment with the flexibility to arrange my working schedule and enable me to study and work at the same time.

My gratitude also goes to the members of the Elk Grove Village Seventh-day Adventist Church, where I have been serving as their pastor for the last nine years. They were praying for me and have shown a lot of patience for their pastor/student.

I cannot express how much I am thankful to my lovely wife Andreja and my children Mateja and Michael for their support, patience, faith in me, prayers and willingness to suffer with me during this prolonged journey.

Final thanks go to the God, the source of all power and goodness. While all help, contributions and support were very important, without His gifts this study would not have been possible. 


\section{CHAPTER 1}

\section{INTRODUCTION}

Power is an integral aspect of all types of leadership. Leaders exist in the moral space of leadership according to how appropriately they use power. Christian leaders are no exception. Every pastor, priest, elder, deacon, teacher, or any other person in a position of influence in the church must find ways of directing personal leadership conduct in accordance with the ideals of the Christian faith. This is not an easy task. We all have witnessed, to some extent, an inappropriate use of power in our leaders or even in ourselves.

While exercising scholarly influence ${ }^{1}$ and engaging in discourse on Christian leadership power, this study investigates the phenomenon of leadership and its moral dimension, particularly the misuse or abuse of power. This introduction delineates essential concepts related to the problem of power abuse such as power, authority, abuse of power and introduces the case used in the study.

${ }^{1}$ Catherine Keller eloquently explained, "Any reflection about power is at the same time an act of power-an exercise of influence within the matrix of relations, itself demanding accountability." (Catherine Keller, "Power Lines," in Power, Powerlessness, and the Divine: New Inquiries in Bible and Theology, ed. Cynthia L. Rigby (Atlanta, GA: Scholars Press, 1997), 58.) Thereby, this study itself is an exercise of influence and encounters the challenge of the use of power. 


\section{Concept of Power}

A brief review of scholarship on the issue of power starts with the statement of well-known sociologist Max Weber that power "is the probability that one actor within a social relationship will be in a position to carry out his own will despite resistance, regardless of the basis on which this probability rests." ${ }^{2}$ That power is either coercive or authoritative. What differentiates these two categories is that coercion is an exercise of power through force, whereas authoritative power is a legitimate power because the subject of the power accepts the person's authority and consents to the exercise of that power. Weber's authoritative power is expressed as charismatic authority, traditional authority, and rational-legal authority.

Sociologist Steven Lukes used the zero-sum approach (gains for some entailing equivalent losses for others) ${ }^{3}$ to address the issue of power in his 1974 book Power: $A$ Radical View, proposing a "three-dimensional" approach to power. ${ }^{4}$ Lukes' three dimensions of power are described as one-dimensional power - the power of those who get their way in the decision-making process, two-dimensional power - the power of those who successfully manage an agenda and control what is discussed, and threedimensional power - the power of those who are able to shape the wishes and desires of others without their knowledge. Three-dimensional power is the most elusive and subtle

${ }^{2}$ Max Weber, Economy and Society: An Outline of Interpretive Sociology (Berkley. CA: University of California Press, 1978), 53.

${ }^{3}$ James H. Read, "Is Power Zero-Sum or Variable-Sum? Old Arguments and New Beginnings," Political Science Faculty Publications 3-2012, no. 4 (2012), http://digitalcommons.csbsju.edu/polsci_pubs/4. 2005).

${ }^{4}$ Steven Lukes, Power: A Radical View, 2nd ed. (New York: Palgrave - Macmillan, 
type of power. ${ }^{5}$ Regardless of the enormous influence of his work, Lukes added two new chapters in the second edition of his book, admitting that his initial approach was partial and one-sided on two levels: it focused only on the exercise of power and only addressed asymmetric power - power over others. While in the third chapter of second edition of the book he explains and defends the concept of three-dimensional power, in the second chapter he seeks to broaden the discussion on power and addresses the critique of his original work. In that chapter, he discusses the work of another influential theorist of power of the late twentieth century Michel Foucault. ${ }^{6}$

Considering Foucault's influence, it is not surprising that Lukes dedicated almost twenty pages to discuss Foucault's ideas on power and discourse they ignited. ${ }^{7}$ James H. Read categorically places Foucault in the zero-sum approach group. Despite this fact, Foucault's definitions and description of power share elements with Talcott Parsons' view on power, which is the variable-sum approach (both mutual gains and mutual losses of power are possible). ${ }^{8}$ Foucault sees power as a necessity to achieve goals and produce results, but not something that only certain individuals or leaders possess: "Power is

${ }^{5}$ Clarissa Rile Hayward in her essay On Power and Responsibility summarizes the essence of Lukes' views: "that exercising power can be a matter of, not only prevailing in conflict (what Lukes calls 'the one-dimensional view') and forcibly suppressing conflict (the 'twodimensional view'), but also gently suppressing conflict by shaping people's wants and desires, their beliefs and perceptions. It is 'the supreme exercise of power,' Lukes argues persuasively, 'to get another or others to have the desires you want them to have': to engender the willing participation by the powerless in their own domination (p. 27)." (Clarissa Rile Hayward, "On Power and Responsibility," Political Studies Review 4 (2006).)

${ }^{6}$ Steven Lukes, Power: A Radical View, 60.

${ }^{7}$ Ibid., 88-107.

${ }^{8}$ James H. Read, "Is Power Zero-Sum or Variable-Sum? Old Arguments and New Beginnings." 
everywhere; not because it embraces everything, but because it comes from everywhere.... power is not an institution, and not a structure; neither is it a certain strength we are endowed with; it is the name that one attributes to a complex strategical situation in a particular society." ${ }^{, 9}$ For Foucault, power is not merely a coercive and negative force: "We must cease once and for all to describe the effects of power in negative terms: it 'excludes', it 'represses', it 'censors', it 'abstracts', it 'masks', it 'conceals.' In fact, power produces; it produces reality..."10 Thereby, power is "something which circulates", ${ }^{11}$ it is the interaction of influences present in any group or society. ${ }^{12}$

Additionally, Foucault's frequent use of power/knowledge reflects Bacon's claim that "knowledge is power." Discourse is a method employed by using knowledge to influence subjects of power. But discourse can also be used for resisting power. According to Foucault, "Discourse transmits and produces power; it reinforces it, but also undermines and exposes it, renders it fragile and makes it possible to thwart."13

${ }^{9}$ Michel Foucault, The History of Sexuality, trans. Robert Hurley (New York: Pantheon Books, 1978), 93.

${ }^{10}$ Michel Foucault, Discipline and Punish: The Birth of Prison, trans. Alan Sheridan (New York: Vintage Books, 1979), 194.

${ }^{11}$ Michel Foucault and Colin Gordon, Power/Knowledge: Selected Interviews and Other Writings, 1972-1977, 1st American ed. (New York: Pantheon Books, 1980), 98.

${ }^{12}$ In his essay, Jonathan Gaventa explains that Foucault's power is "diffused rather than concentrated, embodied and enacted rather than possessed, discursive rather than purely coercive, and constitutes agents rather than being deployed by them." (Jonathan Gaventa, "Power after Lukes: An Overview of Theories of Power Since Lukes and Their Application to Development," (2003), accessed October 7, 2015, www.powercube.net/wpcontent/uploads/2009/11/power_after_lukes.pdf.)

${ }^{13}$ Michel Foucault, The History of Sexuality, 101. 
That relational nature of power is also strongly emphasized in the work of Talcott Parsons who, according to James H. Read, “appears principally responsible for introducing the terms 'zero-sum,' 'variable-sum,' 'power-to,' and 'power-over' into the power literature. Numerous authors on power have subsequently adapted such usages, including Parsons' critics." 14

Following this discourse on power, there are many attempts to define power. For example, William Schweiker asserted, "Power itself is the ability or capacity to influence, respond to, and shape reality. In this way, ideas, as well as persons and institutions, have power insofar as they constitute some reality." 15 According to Harvey G. Cox, "Power is the capacity to effect intended results." ${ }^{\text {" }}$ Stephen Covey stated, "Power is the capacity to act, the strength and courage to accomplish something. It is the vital energy to make choices and decisions. It also represents the capacity to overcome deeply embedded habits and to cultivate higher, more effective habits." ${ }^{17}$ John French and Bertram Raven strove to "define power in terms of influence" 18 of one person over another in order to achieve change. All those definitions have one thing in common. They present power as

\footnotetext{
${ }^{14}$ James H. Read, "Is Power Zero-Sum or Variable-Sum? Old Arguments and New Beginnings."

${ }^{15}$ William Schweiker, Power, Value, and Conviction: Theological Ethics in the Postmodern Age (Cleveland, OH: Pilgrim Press, 1998), 148.

${ }^{16}$ Harvey G. Cox, "Power," in A New Dictionary of Christian Ethics, ed. James F. Childress; John Macquarrie (London: SCM Press Ltd, 1990), 489.

${ }^{17}$ Stephen R. Covey, Principle-Centered Leadership, 1st ed. (New York: Simon \& Schuster, 1992), 23.

${ }^{18}$ John R. P. French, Jr. and Bertram Raven, "The Bases of Social Power," in Studies in Social Power, ed. Dorwin Cartwright (Ann Arbor, MI: Research Center for Group Dynamics Institute for Social Research University of Michigan, 1959), 15.
} 
influence capable of producing actions or changes. Power as influence is a crucial component of leadership. John C. Maxwell stated, "The true measure of leadership is influence — nothing more, nothing less. If you do not have influence, you will never be able to lead others." ${ }^{19}$ Additionally, power is a means to order life, specify goals, and distribute goods.

Because of the powerful effects and results of the use of power, there are some attempts to limit the definition of power to coercive power only. Following Weber's definition of power, Antonio Campolo Jr. in The Power Delusion proposes this definition of power: "I am defining power as 'the prerogative to determine what happens and the coercive force to make others yield to your wishes—even against their own will." ${ }^{20}$ Campolo labels the coercive use of power "power," and the use of the power of a legitimate leader without coercion "authority." The simple conclusion based on that definition is that the use of coercive power in Christian settings is wrong. Although Campolo's study encompasses the issue of power abuse in all spheres of Christian life, his simplistic division of power according to coercive power and power with authority is problematic. Leaning on Nietzsche's ideas, while simultaneously rejecting his atheistic beliefs on which those ideas are built, does not completely reflect the application of power in Christian settings.

Discourse on power suggests that power is a much more complex phenomenon. Appropriating diverse uses of power must be evaluated with many more variables than simply examining whether the use of power is coercive or not. Numerous methods of the

${ }^{19}$ John C. Maxwell, The 21 Irrefutable Laws of Leadership (Nashville: Thomas Nelson, 1998), 11, 20.

${ }^{20}$ Anthony Campolo Jr., The Power Delusion (Wheaton, IL: Victor Books, 1983), 11. 
use of power can be correctly and rightfully employed (including coercive power) if the correct amount and type of authority are used. Although rare, situations arise when the coercive use of power in a Christian setting is justified, such as Jesus' use of power in cleansing the temple. However, His use of coercive power included the authority and legitimate right He possessed in Himself. Despite the weakness of his definition of power, Campolo correctly attached the legitimate and appropriate use of power to an appropriate use of authority. Some scholars depict power and authority in equivalent terms. This study investigates power and authority as two diverse terms whose distinctions must be elucidated.

\section{Power and Authority}

Authority is a crucial concept for understanding power. Although power and authority are closely linked, they are not synonyms. Jacques Maritain clearly distinguished between authority and power: "Authority and Power are two different things: Power is the force by means of which you can oblige others to obey you. Authority is the right to direct and command, to be listened to or obeyed by others. Authority requests Power. Power without authority is tyranny." ${ }^{21}$ Authority without power is not effective, and authority that uses more power than it has the right to exercise is an abuse of power.

Christian views on authority differ from secular views on authority. That difference has been reflected in a shift of scholarly discussions on authorities from using 126.

${ }^{21}$ Jacques Maritain, Man and the State (Chicago: University of Chicago Press, 1962), 
the term "higher authority" to the term "moral authority." 22 This is most likely the result of a scholarly community attempting to avoid conflict over the question of who is that higher authority. Consequently, from the secular point of view, moral authority is determined by social consensus, respect for the position, or by the knowledge or expertise of that authority. For Christians, God is the highest and supreme authority, the ultimate authority from whom all authorities derive. ${ }^{23}$

Bernard Ramm described several distinctive types of authority. ${ }^{24}$ Two of them are significant for this study. "Imperial authority means the right to rule and prescribe because of the superior position of the ruling person or the group." 25 "Delegated authority is the authority to act, to compel to have access to, in virtue of the right granted by imperial authority." 26 Their differences are based on the source of their power. First, imperial authority (monarchic, absolute authority which holds supreme power) is based on power derived from the pedigree or position of the person in possession of that authority. Christians believe the ultimate source of power-imperial authority-is God

\footnotetext{
${ }^{22}$ Harold Waterman describes the occurrence of this shift: "Originally, the concept of servant leadership included a clear idea about the term "higher authority," and early literature closely tied the concept to religious theology (Robinson 2009). Greenleaf alludes to a "calling" but does not identify any specific entity or higher presence. However, this is an uncomfortable idea in today's predominantly less religious society, so the modern meaning of the phrase can be considered more to concern "goodness" and the primacy of moral authority." (Harold Waterman, "Principles of 'Servant Leadership' and How They Can Enhance Practice," Nursing Menagement 17, no. 9 (2011): 26.)

${ }^{23}$ See: Rom. 13:1.

${ }^{24}$ These authorities are: imperial authority, delegated authority, stipulative authority, veracious authority, functional authority, and authority of custom. (Bernard L. Ramm, The Pattern of Religious Authority (Grand Rapids, MI: Eerdmans, 1965), 10-12.)

${ }^{25}$ Ibid., 10.

${ }^{26}$ Ibid., 11.
} 
Himself. ${ }^{27}$ Second, delegated authority uses power derived from the delegation of authority from an imperial authority or from a vote of confidence expressed by those who are led.

The appropriateness of power use and methods employed by that power are proportional to the legitimacy of the authority utilized in the application of power. Abuses of power are closely related to overstepping or undermining authority.

\section{The Problem of Power Abuse}

Scholars concur in describing power as the capability to produce change and influence the subjects of that power. ${ }^{28}$ Power does not exist in a vacuum and is present in all spheres of life. ${ }^{29}$ The discourse on power that describes the relational nature of power is particularly crucial for the use of power in Christian settings because the essence of Christianity is a loving relationship with God that extends to a loving relationship with

${ }^{27}$ See: Col. 2:9-10; Eph. 1:19-21, Eph. 6:10; Jude 1:25.

${ }^{28}$ The discourse on the power abuse in Christian leadership produced some excellent studies on the issue such as: Anthony Jr. Campolo, The Power Delusion; David Johnson and Jeffrey VanVonderen, The Subtle Power of Spiritual Abuse (Minneapolis, MN: Bethany House Publishers, 1991); Richard J. Foster, Money, Sex \& Power: The Challenge of the Disciplined Life (San Francisco, CA: Harper \& Row, 1985); James N. Poling, The Abuse of Power: A Theological Problem (Nashville, TN: Abingdon Press, 1991); Paul Beasley-Murray, Power for God's Sake: Power and Abuse in the Local Church (Carlisle, PA: Paternoster, 1998). and very recent Andrew Hardy, Richard Whitehouse, and Dan Yarnell, Power and the Powers: The Use and Abuse of Power in its Missional Context (Eugene, OR: Cascade Books, 2015). This section is enriched with the ideas from the authors of mentioned books.

${ }^{29}$ Rodney Werline described the relational nature of power: "Although cultures develop ideas about power, power becomes real in a human's ability to act on another human or to influence the actions of another human. This statement locates power finally as something between humans - power is relational. Therefore, an understanding of power becomes as complex as the analysis of all the possible ways in which humans relate to one another." (Rodney A. Werline, "Prayer, Politics, and Power in the Hebrew Bible," Interpretation: A Journal of Bible and Theology 68, no. 1 (January 2014), accessed October 7, 2015, Academic Search Complete, EBSCOhost.) 
one's fellow man (as Jesus explained in Luke 10:27: "So he answered and said, 'You shall love the LORD your God with all your heart, with all your soul, with all your strength, and with all your mind,' and 'your neighbor as yourself'"'). Christian leaders are to use power in a relationship network or matrix in which power flows not just in one direction.

Martha Stortz in her book about the use of power in pastoral service Pastorpower, proposed the existence of three types of power: "“power over,' "power within' or charismatic power, and 'power with,' friendship or coactive power."30 Building on Foucault's claim that we must cease perceiving power only in negative terms, power is neither intrinsically good nor bad. Plato, in his tale of the Ring of Gyges,${ }^{31}$ recognized that the greatest challenge of power is not how to obtain it, but rather how to control it and eliminate uncontrolled and unlimited power. Thereby a different method of power use can be correctly and rightfully employed. All power: "power over," "power within," and "power with" can be properly used or misused.

Campolo warns: “... the coercive nature of power gives expression to its potential for evil. Coercion is the crux of why power is irreconcilable with Christianity." 32 Campolo's statement follows the Protestant tradition. In a diversity of Christian traditions, the Protestant tradition, contrary to the Roman Catholic and Orthodox traditions, at least in theory, is known for its radical and supposedly biblically supported rejection of any human authority with power over the church, including that of preachers,

${ }^{30}$ Martha Ellen Stortz, PastorPower (Nashville: Abingdon Press, 1993), 41-42.

${ }^{31}$ Plato, The Republic, trans. G. R. F. Ferrari and Tom Griffith, Cambridge texts in the history of political thought (Cambridge, NY: Cambridge University Press, 2000).

${ }^{32}$ Anthony Campolo Jr., The Power Delusion, 11. 
priests, bishops, patriarchs, or popes. Regardless of the tradition that Christian leadership follows, abuses of power are related to overstepping the authority the leader possesses.

The term "abuse of power" describes an inappropriate and corrupt application of power. The exercise of power becomes an abuse of power when a person in a position of power acts in a manner that cannot be justified in terms of truth or morality (goodness, kindness, justice, or obedience). The justification for the exercise of power comes through authority. As previously mentioned, applying power without a legitimate authority is an abuse of power. Nevertheless, not applying power when the authority requires it, is an abuse of power as well.

Abuse of power entails how we apply power and how we treat those we lead. Beasley-Murray noticed that "at the heart of all abuse is misuse of power. It is about relating in ways which in some way diminishes the other, rendering them to some degree impotent and powerless. It is about manipulation and control." 33

Certain abuses in Christian leadership are unique to spiritual leadership. David Johnson and Jeff VanVonderen emphasized that uniqueness by referring to those abuses as spiritual abuses. ${ }^{34}$ They compiled an extensive list of these abuses and defined them as "the mistreatment of a person who is in need of help, support, or greater spiritual empowerment with the result of weakening, undermining, or decreasing that person's spiritual empowerment." 35 The use of "God's will," or implying the use of God's authority in support of personal decisions to manipulate the subject of power is an

\footnotetext{
${ }^{33}$ Paul Beasley-Murray, Power for God's Sake: Power and Abuse in the Local Church, 8.

${ }^{34}$ David Johnson and Jeffrey VanVonderen, The Subtle Power of Spiritual Abuse.

${ }^{35}$ Ibid., 20.
} 
example of such power abuse. Cult leaders use this type of power abuse, which can unfortunately be used by any religious leader. Richard Foster warned about a danger of people identifying their opinion with the will of God. ${ }^{36}$ In Christian circles, power abuses might also be hidden behind higher goals and divine purposes. Most of these purposes contain pious and "spiritual" justifications and are often presented as something "for God's sake, even though the real underlying issue may have had nothing to do with God himself." ${ }^{37}$ Although certain power abuses can be easily determined, such as sexual abuse, the substitution of one's opinion with God's will is an abuse that is difficult to detect and to characterize as such. Beasley-Murray highlighted an example of such abuse by pointing to the requirement of the "Harvestime" Restoration group of churches in Bradford "to put submission to the leaders of the church on the same level as submission to God." 38

The abuse of power often starts with believing oneself to be better than others. Although it might be true that a leader is indeed more qualified and talented than others are, a feeling of superiority creates a wrong attitude toward others. As stated by Martyn Percy, "a sense of detachment and superiority is a failure of power, and corruption of

${ }^{36}$ Richard J. Foster, Money, Sex \& Power: The Challenge of the Disciplined Life.

${ }^{37}$ Paul Beasley-Murray, Power for God's Sake: Power and Abuse in the Local Church, 5.

${ }^{38}$ The whole text is as follows: "An early membership handbook emanating from the 'Harvestime' Restoration groups of churches based in Bradford put submission to the leaders of the church on the same level as submission to God. In this handbook the injunction to 'obey your leaders and submit to them' (Heb. 13:17) was paralleled with James 4:7 which calls Christians to 'submit [themselves] to God'-implying that there is little difference between 'submission' to the elders and 'submission' to God. One obvious difference, of course, is that human leaders are fallible, whereas God is infallible" (ibid.). 
authority." ${ }^{39}$ An over-estimation of my own value, together with a belief that I am the rightful owner of power, can easily lead to the abuse of power. Forbes pointed out, "It was the desire to be powerful — to be like God — that caused Adam and Eve to disobey the Lord. Satan understood from firsthand experience how great was the call of power: He fell from heaven because he longed to be greater than he was." 40 Such feelings of superiority are frequently caused or boosted by the behavior of subordinates who, either for personal gain, fear of consequences, or because of a feeling of inferiority, glorify their bosses and do not express disagreement with their position. Such an attitude toward a leader can initiate a feeling of irreplaceability. An unwanted consequence is that a leader might forget that every leader is merely another human with limited knowledge and capabilities, and that every group can achieve the biggest accomplishments when the efforts and talents of every member of the group are united in a common goal.

Power abuse includes a certain level of disrespect for others. "Pastoral leadership must always respect the conscience of another." 41 Therefore, ignoring or disrespecting the conscience of others is an abuse of power. "Respect is the missing ingredient where the abuse of power is operating — respect for the worth of another and their right to their opinion." ${ }^{42}$ Lack of respect for others caused by feelings of superiority, obsession with power, selfish wishes to take advantage of being in charge, attempts to boost one's own

${ }^{39}$ In the Foreword of Power for God's Sake (ibid., xiv.)

${ }^{40}$ Cheryl Forbes, The Religion of Power (Grand Rapids, MI: Zondervan Publishing House, 1983), 109.

${ }^{41}$ Paul Paul Beasley-Murray, Power for God's Sake: Power and Abuse in the Local Church, 81.

${ }^{42}$ Ibid. 
self-esteem, efforts to create one's own legacy, or ignoring the ideas and solutions of others always end up in some kind of abuse of power.

That a serious leader has a feeling of responsibility and, consequently, a duty to make decisions and to lead is important to emphasize. However, when a leader's position is suddenly threatened or challenged, the leader might overreact and apply an inappropriate amount of power out of fear that he/she is losing control. The leader might feel that something must be done to regain control. Poling asserted, "Abuse of power for the individual is motivated by fear and by the resulting desire to control the power of life." ${ }^{43}$ Therefore, abuse of power in such a case is the result of the leader's insecurity. Abuses of power and the conflicts created by them have a destructive effect on churches and people led by abusive leaders. Even though all abuses of power are damaging, "covert forms of abuse are particularly destructive and damaging, undermining people's integrity and self-worth, causing them to doubt their own reality and perceptions, causing them to deny the validity of their own feelings and insights."44

Abuse of power may cover a broad spectrum of deviations, such as authoritarianism, ${ }^{45}$ use of power for personal advantage, double standards, intimidation of those under a powerful leader, self-sufficiency, and blindness to the needs of others. As previously indicated, abuses may be fueled by such motives as selfishness, pride, fear,

${ }^{43}$ James N. Poling, The Abuse of Power: A Theological Problem, 27.

${ }^{44}$ Paul Paul Beasley-Murray, Power for God's Sake: Power and Abuse in the Local Church, 10.

45" Authoritarianism appears when the submission that is demanded cannot be justified in terms of truth or morality" (J. I. Packer, Freedom, Authority \& Scripture, 1st British ed. (Leicester, England: Inter-Varsity Press, 1982), 16.) 
ignorance, or evil. The list of abuses of power in Christian leadership can be extensive. ${ }^{46}$ Consequently, from the Christian perspective abuses of power are a deviation of Christian leadership.

Schweiker stated, "We live in an age of increasing human power, and this fact moves responsibility to the center of ethics. The moral question is how, if at all, the use of power can be directed and evaluated." ${ }^{47}$ Therefore, the greatest challenge Christian leaders face is how and in which situations they can properly apply their power, namely "power over" or "power within." Resembling that challenge, leaders in the Seventh-day Adventist Church are not immune to the corruptibility of power. Although a unique organizational structure of the church might suppress or diminish the possibility of certain types of power misuse, in the end, the use of power is determined by the leader's conduct, decisions, visions, and influence. During the more than 170 years of the movement's history, abuses of power have been present. Consequently, facing the problem of power abuse is necessary and cases in the history of the church can be used for studying the problem.

\footnotetext{
${ }^{46}$ For example Campolo's list of abuses in The Power Delusion includes: sexual manipulation for gaining power, using a position of power for sexual pleasure, the leader solely performing all jobs, preventing others to use their gifts, sharing power and power positions only with those whom the leader can control, not telling the truth for fear of losing the position of power and making members angry, requiring complete compliance with the leader's own views, using charisma to control the church instead of leading people, using power without implementing any control system, corruption in behavior based on a personal sense of power, being above the rules and laws, doing favors for people to gain their allegiance, exercising power or fighting to gain power to compensate for a sense of powerlessness in other aspects of life, blackmailing others with the threat of resignation and leaving, engaging in political power. (Anthony Jr. Campolo, The Power Delusion.)

${ }^{47}$ William William Schweiker, Power, Value, and Conviction: Theological Ethics in the Postmodern Age, 143.
} 


\section{The Case for Study}

As a case study for an ethical analysis of the abuse of power, this study investigates a case in the Seventh-day Adventist Church called "kingly power." ${ }^{\text {" The }}$ term is found in the writings of one of the founders of the Seventh-day Adventist church, Ellen White. Using that term, she addressed the issue of power abuse that seriously affected the Seventh-day Adventist church at the end of nineteenth century and beginning of the twentieth. Although that there has been no period without some misuse of power, at that time the future of the church was threatened with a possibility of schism and disintegration. White saw the reasons for that threat in the centralization of power in two supposedly concurring branches of the church, ministerial and medical, and their fight for authority, power and resources. That power struggle was intensified with the personal conflict among strong, authoritarian leaders who often behaved more as rulers than Christian leaders. ${ }^{49}$ In her reaction to the problem she wrote: "God has not set any kingly power in the Seventh-day Adventist Church to control the whole body, or to control any

${ }^{48}$ See Colin D. Standish and Russell R. Standish, Embattled Church (Rapidan, VA: Hartland Publications, 1995), 131; George R. Knight, From 1888 to Apostasy: The Case of A.T. Jones (Washington, DC: Review and Herald Pub. Association, 1987), 186; Arden W. Clarke, "And the people said, 'We will serve the Lord"': an analysis of church government (Brushton, NY: TEACH Services, 2001), 5; Barry David Oliver, SDA Organizational Structure: Past, Present, and Future, vol. XV, Doctoral Dissertation Series (Berrien Springs, MI: Andrews University Press, 1989); George R. Knight, If I Were the Devil: Seeing Through the Enemy's Smokescreen: Contemporary Challenges Facing Adventism (Hagerstown, MD: Review and Herald Pub., 2007), 87; George R. Knight, Organizing to Beat the Devil: The Development of Adventist Church Structure (Hagerstown, MD: Review and Herald Pub. Association, 2001); Richard Schwarz and Floyd Greenleaf, Light Bearers: A History of the Seventh-day Adventist Church (Nampa, ID: Pacific Press, 2000).

${ }^{49}$ Chapter 3 gives a more extensive historical context of "kingly power" issue. 
branch of the work. He has not provided that the burden of leadership shall rest upon a

few men. Responsibilities are distributed among a large number of competent men."50

Ellen White used the term "kingly power" in several ways. By using the term "kingly power," she pointed to Christ's power as Ruler of the universe,${ }^{51}$ His power when He sat with His Father, the power He had when He was preaching or performing miracles, and the power He will exercise when He comes the second time. ${ }^{52}$ Kingly power is what Jesus possesses, although He chose to lay aside his power and authority in order to save the human race. ${ }^{53}$ She also used the same phrase to describe our ability to reason or the power of our will. ${ }^{54}$ She described the authority and power of earthly rulers

${ }^{50}$ Ellen White, Testimonies for the Church, vol. 8 (Nampa, ID: Pacific Press, 2002), 236.

${ }^{51}$ Ellen White, The Desire of Ages (Nampa, ID: Pacific Press, 2005), 799.

${ }^{52}$ She pointed out the expectations of the disciples that Jesus would assert "His kingly power" (Ellen White, Christ Triumphant: Devotional Meditations on the Great Controversy Story (Hagerstown, MD: Review and Herald 1999), 253.) The disciples expected Him to be exalted to the position of rightful power (Ellen White, Conflict \& Courage (Hagerstown, MD: Review and Herald, 2005), 314; Ellen White, The Desire of Ages, 800.) It is also reflected in the expectations of the Jews regarding the manner of the Messiah's coming (Ellen White, Redemption, or, The teachings of Christ, the Anointed One, Life of Christ (Battle Creek, MI: Steam Press of the Seventh-day Adventist Publishing Association, 1877), 4.) "Kingly power" is also the power of the Savior coming to gather the saved during His second coming (Ellen White, Early Writings of Ellen G. White (Hagerstown, MD: Review and Herald, 2000), 251; Ellen White, Spiritual Gifts, vol. 1 (Battle Creek, MI: Steam Press of the Seventh-day Adventist Publishing Association, 1858), 157; Ellen White, "Tempted in All Points Like as We are," Bible Echo and Signs of the Times vol. 7, no. 21 (November 1st 1892): 322; Ellen White, "Draw from the Source of Strength," The Signs of the Times (October 10th 1892).) This is the power of Jesus, which even those who crucified Him will see. "But then they will be obliged to see Him in all His glory and kingly power" (Ellen White, Early Writings of Ellen G. White, 179.)

53،"He might have come to this world in the glory of his kingly power. But he chose to come to this world in the garb of humanity, and to live a life of self-denial and sacrifice" (Ellen White, "A Visit to the South," The Review and Herald, no. 2 (August 18 1904).)

54،"The kingly power of reason" is a common phrase she uses to depict the power to make our own choices, the power of the will. "It is God's purpose that the kingly power of sanctified reason, controlled by divine grace, shall bear sway in the lives of human beings. He who rules his spirit is in possession of this power" (Ellen White, The Ministry of Healing (Mountain View, 
using the same term. ${ }^{55}$ However, she used the same phrase when referring to leadership authority in the church. ${ }^{56}$ In all these scenarios, except for the last, the meaning of "kingly power" is positive, but when she discussed the problem of using power in the church, she strongly opposed the use of a power that she called "kingly" describe an inordinate use of power (abuse of power) among Seventh-day Adventist leaders. ${ }^{58}$

The reason for concentrating on the specific issues of kingly power in the Seventh-day Adventist Church is that all abuses of power in Christian leadership are based on similar patterns and include similar principles. Limiting an investigation to only one case will enable a possible and plausible case analysis, providing results that can be applied to Christian leadership at large.

Abuses of power covered by the "kingly power" issue include, but are not limited to, use of excessive power, authoritarianism, an inappropriate centralization of power in

CA: Pacific Press 1905), 130; Ellen White, Conflict \& Courage, 249; Ellen White, My Life Today: The Morning Watch Texts with Appropriate Selections from the Writings of Ellen G. White (Washington, DC: Review and Herald, 1952), 318.) See also Ellen White, Counsels On Diet And Foods (Washington: Review and Herald Pub. Association, 1976), 73; Ellen White, Christian Temperance (Battle Creek, MI: Good Health Publishing Company, 1890), 147-148.

${ }^{55}$ Ellen White, Patriarchs and Prophets (Oakland, CA: Pacific Press, 1890), 698.

${ }^{56}$ Ellen White, Testimonies for the Church, vol. 5 (Nampa, ID: Pacific Press, 2002), 236.

57“Human, kingly power among God's people in any branch of his cause, as represented by the documents prepared for men to sign, is not ordained of God." (Ellen White, Manuscript Releases: From the Files of the Letters and Manuscripts, vol. 4 (Washington, D.C.: E. G. White Estate, 1990), 72.)

58“'In the work of God no kingly authority is to be exercised by any human being, or by two or three" (Testimonies for the Church.) 
the church, and a struggle over primacy and control among the church leaders. ${ }^{59}$ In order to conduct an ethical analysis of power abuse, this study will limit its focus to analyzing the leadership of the two most prominent leaders involved in the controversy and labeled by Ellen White as leaders who exercised "kingly power": the leader of the medical branch of the Seventh-day Adventist Church at the time of the "kingly power" struggle, John Harvey Kellogg, and the leader of the ministerial branch and president of the General Conference (GC) of the Seventh-day Adventist Church, Arthur Grosvenor Daniells, who held the office longer than any other leader in church history. ${ }^{60}$

\section{Statement of the Problem}

This dissertation is concerned with the abuses of power in the church, which have existed in Christian leadership for centuries, and in the Seventh-day Adventist church as well. Nevertheless, no scholarly study on the moral dimensions of abuses of power in the Adventist church has been done. Although, those abuses are well known, without an ethical analysis of these experiences, important lessons of how Christian leaders might deal with the corruptive nature of power are not learned.

\footnotetext{
${ }^{59}$ See George R. Knight, Organizing to Beat the Devil: The Development of Adventist Church Structure; Richard Schwarz and Floyd Greenleaf, Light Bearers: A History of the Seventh-day Adventist Church; Ellen White, Letter 49, 1903, to A.G. Daniells and his fellow workers (Ellen G. White Estate Branch Office Document File, 1903).

60" God would have you a thoroughly converted man. The work of conversion is to begin in your heart and to work outward in your life. You are no to exercise a kingly power, as you certainly have done in the past." (Letter 52, 1903, p. 1 (To J. H. Kellogg, April 5, 1903.) Ellen White, Manuscript Releases: From the Files of the Letters and Manuscripts, vol. 4 (Washington, D.C.: E. G. White Estate, 1990), 292.) "Let us be careful how we press our opinions upon those whom God has instructed. 'If any of you lack wisdom, let him ask of God.' Brother Daniells, God would not have you suppose that you can exercise a kingly power over your brethren." (Letter 49, 1903, p. 3. (To Elder Daniells and his fellow workers.) Ellen White, Manuscript Releases: From the Files of the Letters and Manuscripts, vol. 4 (Washington, D.C.: E. G. White Estate, 1990), 293.)
} 


\section{Purpose and Justification}

Christian leaders of all denominations are not more immune to failure or sin than are those whom they are supposed to lead. They, as all other leaders, can and sometimes do abuse their power. In his essay on the priesthood of all believers, Alister E. McGrath points out that the Reformation was a protest of God's people against the abuses of their totalitarian Christian leaders. He states, "But with the Reformation came a slogan-a slogan that needs to be splashed onto new banners again today: ecclesia semper reformanda - the church must always be reforming itself. In other words, reformation is

not a once-and-for-all event, but a continuing process." ${ }^{\prime 1}$ To paraphrase the slogan of the Reformation, the Christian leader must incessantly undergo reformation. Thereby, Christian leadership is an activity in progress. Continual evaluation and improvement of leadership practice are necessary.

We can hide our head in the sand like the ostrich and ignore the prevalent problem of power abuse, or we can face the problem. The purpose of this study is to identify and to critically analyze the causes for the abuses of power among Christian leaders, to evaluate the moral consequences of the abuses of power, and to look for possible ways or methods of avoiding them. The goal is not to criticize or to point out the weakness of previous Christian leaders, but rather to learn how to improve Christian leadership practices from their mistakes. Using the proposed methodology below, this study will examine the well-documented controversy from Seventh-day Adventist history

\footnotetext{
${ }^{61}$ Alister E. McGrath, "A Better Way: The Priesthood of All Believers," in Power Religion: The Selling Out of the Evangelical Church?, ed. Michael Scott Horton (Chicago: Moody Press, 1992), 311.
} 
and attempt to determine how the lessons from history can inform contemporary

Christian leadership.

An analysis of power misuse is a necessary first step to avoid the traps of power abuse, and to find possible solutions for enhancing Christian leadership. This study finds its justification in the fact that no study and ethical analysis have been conducted on the problem of the abuses of power in Seventh-day Adventist leadership.

\section{Scope and Delimitations}

As a case study, this research considers historical data from the last decade of nineteenth century and the first decade of the twentieth century connected with "kingly power" in the Seventh-day Adventist Church. Data from other periods are considered as references, clarifications, and explanations, relying on the work of historians and not engaging in the discussion of historical events per se. Instead, this study searches for the moral values necessary for understanding the ethics of power involved in those events.

\section{Methodology and Outline}

As a case study, this dissertation proceeds from description to analysis, followed by evaluation.

The description section delineates Christian ethics, with its biblical basis relative to the use of power in order to establish a positive model and to propose a framework for analyzing power abuses as evidenced in the case of "kingly power." It compares Christian servant leadership to utilitarianism, pragmatism, and Machiavellianism as the pursuit of personal welfare. 
The continuation of the description section of the study depicts the events during the "kingly power" controversy related to the issue of Christian leadership. It elucidates the actions and consequences related to power abuse, and attempts to address them.

The examination and observation section focuses first on the persons in power, their styles of leadership, relationships, manner of acting, attitude, worldview, and the leadership structure that evolved in the process. It investigates their actions, sermons and addresses, correspondence, and documented discussions of the leaders with the intention to describe their abuses of power. This study analyzes power abuses in the conduct of two leaders of the Seventh-day Adventist Church during the kingly power controversy with the framework defined in the description section. The analysis seeks to identify abuses of power in moral terms by asking the questions proposed in the framework.

The aim of the evaluation is to find moral lessons based on a presence of abuses of power and their consequences. It also seeks to learn why abuses of power occur and how they can be prevented and addressed. The moral lessons drawn during the analysis and evaluation will lead to the suggestions for ethically adequate Christian leadership today.

This dissertation is organized as follows:

The first chapter is an introduction to the study. The second chapter includes the theological basis for the Christian perspective on the ethical use of power. Ethical issues connected with the influence of power on leaders are introduced. ${ }^{62}$ This includes important ethical issues and definitions as the criteria on which an ethical analysis of the

\footnotetext{
${ }^{62}$ Northouse suggests in Leadership: Theory and Practice the three most important perspectives on ethical leadership: Heifetz's, Burns,' and Greenleaf's. We discuss them in the second chapter. (Peter G. Northouse, Leadership: Theory and Practice, 4th. ed. (Thousand Oaks, CA: Sage Publications, 2007), 346-350.)
} 
phenomenon of "kingly power" is based. This chapter will end with a description of the paradigm that will be used for the analysis and evaluation of the case study.

The third chapter is a description of the "kingly power" controversy based on pertinent literature and documents necessary for an ethical analysis of the "kingly power" phenomenon.

The fourth chapter analyzes the leadership style and abuses of power of the two most important leaders involved in the controversy using the framework presented in the second chapter. Abuses of power are detected and the consequences of the misuse of power are cited.

The fifth chapter is an evaluation of the analysis from previous chapters, distilling moral lessons based on the issue of "kingly power," finally endeavoring to find ways or methods of overcoming the corruptive nature of power. Some current issues will be included. 


\section{CHAPTER 2}

\section{THEORETICAL FRAMEWORK FOR AN ETHICAL ANALYSIS OF THE ABUSE OF POWER IN CHRISTIAN LEADERSHIP}

The use of power in Christian leadership differs from politics or business. ${ }^{1}$

Sometimes religious circles devalue the importance of power, primarily out of fear that by using the term power one equalizes Christian leadership with political or business leadership. ${ }^{2}$ The scholarly emphasis in sociology on the coercive use of power has contributed to the negative image of power in Christendom. Nevertheless, all Christian leaders have and use power. Unfortunately, the inappropriate use of power among Christian leaders is present as well. The fact that neither the church nor the leaders are perfect produces many challenges for an application of power in the church. Paul

${ }^{1}$ Several years ago I attended an ordination ceremony of a few young pastors. As part of the ceremony, the newly ordained ministers were given the opportunity to address the audience. One of the newly ordained pastors stood behind the pulpit and started his address: "I finally received power!" The word "power" in the language he used conveys authority and executive power. I do not remember the rest of the speech, but I do remember that this sentence raised serious questions: While receiving executive power and authority in business or politics would be acceptable, was it appropriate for a pastor to brag about his authority? Is Christian leadership about power? What is the right place of power in Christian leadership?

${ }^{2}$ As the New Dictionary of Christian Ethics \& Pastoral Theology describes, "The concept of power, and cognate terms such as ability, authority, cause, domination and control, is contested and controversial. The ways in which it is used in theology, in physics, in the social sciences and in everyday life frequently have little to do with one another" ("Power," in New Dictionary of Christian Ethics \& Pastoral Theology, ed. David John Atkinson, David Field, Arthur Frank Holmes, and Oliver O'Donovan (Downers Grove, IL: InterVarsity Press, 1995), 489.) 
Beasley-Murray indicated, "struggles for power and influence are the bread-and-butter diet of many a church, even though such struggles carry pious labels.”3 Joel Gregory described the church as

an institution divine in its original foundation but tethered to this celestial ball by every frailty to which humans are subject. Covetousness, littleness, jealousy, lust for power, ego, sacrilege, and a hundred other demons all lurk within the hallways. . The church on earth at its best is a crippled institution that God may elect to use for his purpose. ${ }^{4}$

The use of power in the church is affected by the weaknesses of the people and the institution. Abuses of power are the results of these weaknesses.

Christian leadership requires a particular framework for an analysis of abuses of power. The final goal of this chapter is to propose the theoretical framework for the ethical analysis of the abuse of power in the "kingly power" case. Christian ethics is defined by a Christian perspective which is formed by the interpretation of the Scripture as the most important source. ${ }^{5}$ Therefore, composing and establishing the theoretical framework begins by introducing its biblical basis followed by the ethics of using power and finishes with proposing the pattern for analysis of abuses of power. In the first section of this chapter, the biblical study is limited to the particular topic of power insofar as it is related to Christian leadership.

${ }^{3}$ Paul Beasley-Murray, Power for God's Sake: Power and Abuse in the Local Church, 3.

${ }^{4}$ Joel C. Gregory, Too Great a Temptation: The Seductive Power of America's Super Church (Fort Worth, TX: Summit Group, 1994), 324.

${ }^{5}$ As Waldo Beach and H. Richard Niebuhr pointed out, "The Bible has always been and will doubtless remain the chief source book for the study of Christian ethics." (Waldo Beach and H. Richard Neibuhr, Christian Ethics: Sources of the Living Tradition (New York: The Ronald Press Company, 1973), 10.) 


\section{Biblical Background for the Ethics of Power}

The issue of power in Scripture is very complex. The word power in the Bible has diverse meanings and various applications. ${ }^{6}$ A diversity of biblical ethical issues additionally increases that complexity and poses the question of the relation of the Scripture and ethics.

${ }^{6}$ Numerous words from the original Bible text are translated as power. According to Keri Kent, the Old Testament of the King James Version uses the word "power" for nearly twenty different Hebrew words. (Keri Wyatt Kent, Deeper Into the Word: Old Testament: Reflections on 100 Words from the Old Testament, Kindle ed. (Baker Book Group, 2011), 171, accessed 1/6/2013.) Those words are translated as "power" but also as "might," "strength." The most frequently used Hebrew word for power is koach פל the ability to do something." (ibid., 172.) Two other common words translated as power are

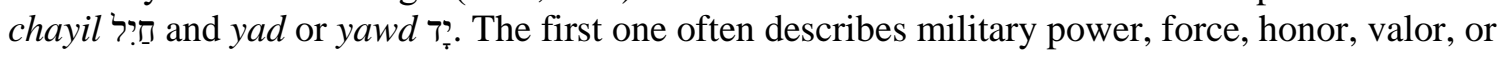
noble character, and the second one is literally translated as a "hand." It is frequently used to describe a person's rule, dominion, or reign.

Four main words and their variations are translated as "power" in the New Testament

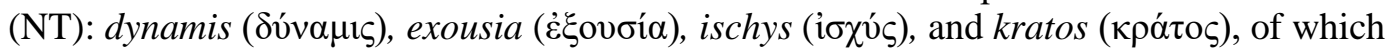
dynamis and exousia are most commonly used. In one instance, the word megaleiotes ( $\mu \varepsilon \gamma \alpha \lambda \varepsilon$ ió $\left.\eta_{\zeta}\right)$ is translated in the KJV as "power."

Grundmann explains the meanings of the word dynamis as "'ability,' then 'possibility,' then 'power' both physical and intellectual or spiritual." (W. Grundmann, "dynamis [ability, power]," in Theological Dictionary of the New Testament, ed. Gerhard Kittel, Gerhard Friedrich, and Geoffrey William Bromiley (Grand Rapids, MI: W.B. Eerdmans, 1985), 187.) Dynamis is used to describe the power of God as an intrinsic characteristic. When power is attached to God, it describes his ability to do things, as well as his majesty (Rom 16:25). The word exouisa, accoding to Foerster, is used for right, authority, and permission. (W. Foerster, "exousia [power to act, authority]," in Theological Dictionary of the New Testament, ed. Gerhard Kittel, Gerhard Friedrich, and Geoffrey William Bromiley (Grand Rapids, MI: W.B. Eerdmans, 1985), 239.) In Eph 6:10, Paul uses ischys to describe God's power and strength. In Rev 5:12, God is worthy to possess strength, ischys, and in verse 7:12, strength, ischys, belongs to God. Wilhelm Michaelis indicates that kratos, "denoting the presence of strength, means a. 'natural strength,' b. the 'power' that one has, or with which one is invested (e.g., divine power, political power, especially in the legal sense), c. 'control,' and d. 'supremacy,' 'superiority,' 'victory."'(W. Michaelis, "kratos [power, strength]," in Theological Dictionary of the New Testament, ed. Gerhard Kittel, Gerhard Friedrich, and Geoffrey William Bromiley, xxxvi, 1356. (Grand Rapids, MI: W.B.

Eerdmans, 1985), 466.) In the NT, it is never used to describe human power, but always refers to God's supreme power, with the exception of Heb 2:14, which states that the devil has the power of death. However, even there, Paul emphasizes that through his own death, God destroys the

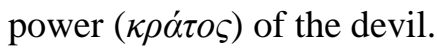


The Westminster Dictionary of Christian Ethics points out that "comprehensive Christian ethical writings use four distinguishable sources: (1) the Bible and the Christian tradition, (2) philosophical principles and methods, (3) science and other sources of knowledge about the world, and (4) human experience broadly conceived." ${ }^{17}$ D. Stephen Long emphasizes the importance of the Scripture as the primary source: "Christian ethics finds its sources in diverse means, but it primarily emerges from the biblical narrative." This study agrees with the majority of scholarly work which accepts the middle ground between to extremes-equalizing Bible ethics with Christian ethics and considering the Bible mostly irrelevant for Christian ethics. ${ }^{9}$ Although biblical ethics is not the same as Christian ethics, Christian ethics is rooted in the biblical teachings, accepts God's

${ }^{7}$ J. M. Gustafson, E. L. Jr. Long, and H. R. Niebuhr, "Christian Ethics," in The Westminster Dictionary of Christian Ethics, ed. James F. Childress and John Macquarrie (Philadelphia: The Westminster Press, 1986), 88.

${ }^{8}$ D. Stephen Long, Christian Ethics: A Very Short Introduction (New York: Oxford University Press, 2010), 23.

9John Brunt and Gerald Winslow in their article "The Bible's Role in Christian Ethics" (John Brunt and Gerald Winslow, "The Bible's Role in Christian Ethics," Andrews University Seminary Studies Vol. 20, no. 1 (Spring 1982).) discussed different approaches for relating the Scripture to ethics. They suggested that five main primary models were being advocated by the scholarship. Those approaches/models are: biblical ethics equals Christian ethics, biblical ethics is generally irrelevant for Christian ethics, God is free to command, the Bible forms traits of character, and the Bible is a resource of normative reflection.

The first two models are extremes. The first one ignores biblical diversity, the complexity of contemporary issues in ethics and changes in culture and society with the passing of time, by equalizing Bible ethics with Christian ethics. The second one considers the Bible mostly irrelevant for Christian ethics. It recognizes biblical diversity but claims that eschatology makes biblical ethics useless and impractical for contemporary application. According to that model, the criterion for determining what is right is ambiguous. If we remove the Scripture as the ground for Christian ethics, what will be the ground of ethical thinking?

The other three models try to cover the space between those two extremes. They are aware of biblical diversity, they do not ignore lapse of time or difference between biblical and contemporary cultures, and they are mindful of the complexity of today's ethical issues. Nevertheless, the basis of their moral thinking has roots in the biblical text. (ibid.) 
authority, seeks ethical principles in the Scripture, and looks for their application in contemporary issues.

Many instances of power abuses are the result of misuse or misinterpretation of the biblical ideas. It is vital to understand those biblical concepts correctly to place authority and power of human beings in an appropriate context. The depiction of the power in the Bible in its ideal form serves as the means of balancing power and authority and avoiding their misuse.

Thus, an ethical analysis of abuse of power in a Christian setting starts with outlining the basic biblical views on power. A suggested leadership model will be determined and delineated by those views. They will also help in producing the framework used for detection of power abuses.

Consequently, biblical background for the ethics of power has to be deducted from the richness and diversity of biblical ideas on power. The richness of the ideas can be seen in the Hans-Ruedi Weber's comprehensive study "Power: Focus for a Biblical Theology." ${ }^{10}$ In this study, he analyzes the biblical narrative on power by comparing six trajectories of biblical faith based on their focus on the theme of power. ${ }^{11}$ Weber follows

\footnotetext{
${ }^{10}$ Hans-Ruedi Weber, Power: Focus for a Biblical Theology (Geneva, Switzerland: WCC Publications, 1989).

${ }^{11}$ Those trajectories are the exodus (Mosaic), the royal (Davidic), the wisdom, the cultic, the anawim (poor of Yahweh), and the apocalyptic traditions. Weber defines those traditions as God's liberating act, God's royal rule, God's enlightening wisdom, God's holy presence, God's vindication of the poor, and God's renewing judgment. He follows them from their sources through the intertestamental time to their NT re-interpretation. In addition to the biblical narrative, for the purpose of historical continuity, his study considers and quotes the intertestamental literature, leaving to the reader to decide its theological significance.
} 
the biblical narrative and challenges common ideas unsupported in the Bible. ${ }^{12}$ His investigation results in an extensive study of a wide spectrum of themes related to power in Scripture based on the biblical narrative. ${ }^{13}$ While Weber presented the richness of the themes related to power, all of them can be grouped into two: the power of God and the power of humans.

The biblical section of the present study, unlike Weber's, is not a comprehensive study of power but rather addresses only the most important biblical concepts related to the issue of power in Christian leadership. Following John Calvin's proposal that the sum of true wisdom is mutually connecting the knowledge of God and the knowledge of ourselves, ${ }^{14}$ and his assumption that one cannot achieve a true knowledge of self without

\footnotetext{
${ }^{12}$ Such an example is the notion that the place of God's authority and power was significantly changed when the political system of the Jews switched from a theocracy to a monarchy. Weber explains: "The royal power entrusted to Davidic kings and to all human rulers like Cyrus, is delegated power under God. Simply to juxtapose theocracy and monarchy in order to see the difference between the exodus and the royal tradition of faith does not do justice to the biblical evidence. According to both traditions, ultimate power and authority belong to God. The distinction lies in the fact that Mosaic faith sees divine power being manifested through direct intervention of God's mighty hand in the realm of creation and human history, while Davidic faith believes that God rules mainly through his anointed representatives. According to the exodus tradition, God's Spirit suddenly empowers charismatic leaders, while according to the royal tradition, God's Spirit remains with the anointed king. As soon as earthly rulers become autocrats and despots they come under severe prophetic criticism, whether they be Davidic kings or not. The stewards of God's royal power must use it responsibly and wisely, for justice and peace. They are held responsible for the way they rule." (Hans-Ruedi Weber, Power: Focus for a Biblical Theology, 58.)

${ }^{13}$ These themes are: the power of God's mighty hand, the power of Yahweh's holy wars, the power of steadfast covenant love, the power of God's elusive presence, the power of God's Anointed King, earthly rulers as servants of God, Jesus: a King and Son of David, the paradox of the crucified King, a realistic assessment of human powers, the renewing power of sacrifice and forgiveness, God's power through powerless, the power of radical hope, and the power of God's kingdom. (ibid.)

${ }^{14}$ See the chapter: Of the Knowledge of God pages 23-27. (John Calvin, Institutes of the Christian Religion: 1541 French Edition, trans. Elsie Anne McKee (Grand Rapids, MI: William B. Eerdmans Publishing Company, 2009).)
} 
first achieving a knowledge of God, it concentrates only on two most important biblical topics related to power: the power of God and the power of human beings. The uniqueness of Jesus as simultaneously being God and human and his unique use (or rejection) of power he (as God) intrinsically possessed, warrants a separate discussion of the exemplary power of Jesus. An appropriate understanding of the relationship between those powers provides a necessary foundation for the framework for the analysis of power abuse among Christian leaders.

\section{Power of God}

In the biblical context, "power is a defining attribute of God." ${ }^{15}$ Despite different traditions and views, universal agreement asserts that one of the most important biblical constructs on God's power based on Ps 62:11 is that "Biblically, all power comes from God and belongs to God." 16 The most obvious expression of God's power is in the creation of the earth and the universe (Jer 10:12; Isa 40:26). Thereby, God possesses intrinsic authority derived from the fact that everything he creates ultimately belongs to him. God can do everything and anything "for with God nothing will be impossible" (Luke 1:37).

That superior power of God gives him the right and ability to distribute, delegate that power and give authority (Luke 10:19). Because human power is received from him and it is not an intrinsic value of mankind, human power is inferior to God's power and depends on his power (1 Cor 2:5). A good example is the delegated power Jesus gave to

\footnotetext{
${ }^{15}$ Keri Wyatt Kent, Deeper Into the Word: Old Testament: Reflections on 100 Words from the Old Testament, 172.

${ }^{16}$ Cox, 489,"Power," in New Dictionary of Christian Ethics.
} 
his disciples: "Then he called his twelve disciples together, and gave them power and authority over all devils, and to cure diseases (Luke 9:1). Therefore, God is the source of all powers (2 Cor 4:7) and power comes from God (2 Tim 1:7).

God is the primal subject in Walter Brueggemann's investigation of the Old Testament theology. He notices that Hebrew theology is concerned with God's action rather than his character. ${ }^{17}$ Therefore, Yahweh is the God who creates, make promises, delivers, commands, and leads. Those verbs have one mutual characteristic-they are an expression of power. Brueggemann also proposes that Israel's testimony follows a pattern of moving from the particular to the general, and from the verb to the adjective, and then to the noun. ${ }^{18}$ Those nouns are a part of the narrative filled with metaphors. The most important metaphors for this study are the metaphors of governance. ${ }^{19}$ They all use images that imply the use of power and God's supreme authority: Yahweh as judge, king, warrior, and father. Those metaphors are used to describe Yahweh's mercy and love, and His awesome power. However, the metaphors of sustenance-Yahweh as artist, healer, gardener-vinedresser, mother, and shepherd-also describe God's power as sustainer and protector. Brueggemann describes that power as "Yahweh's extraordinary power, about which Israel is in no doubt, is a certain kind of power. It is power used toward Yahweh's subject-partner, power used in the work of redress and rehabilitation of those who lack

\footnotetext{
${ }^{17}$ Brueggemann points out that: “... Israel is characteristically concerned with the action of God - the concrete, specific action of God — and not God's character, nature, being, or attributes, except as those are evidenced in concrete actions." (Walter Brueggemann, Theology of the Old Testament: Testimony, Dispute, Advocacy (Minneapolis, MN: Fortress Press, 1997), 145.)

${ }^{18}$ See ibid., 230.

${ }^{19}$ Those metaphors are: Yahweh as judge, Yahweh as king, Yahweh as warrior, and Yahweh as father (ibid., 233-250.)
} 
the requirements of life." ${ }^{20}$ In addition, the Old Testament narrative points out that God's power is based on his sovereignty, faithfulness, fidelity, righteousness, loyalty, presence, holiness, and steadfast love.

Daniel Migliore points out that the NT tradition on God's power is not an entirely different tradition, "The God of the Old Testament and the God of the NT are one and the same God. Jesus does not proclaim a new God, but the very same God who liberated Israel from bondage, gave the law to Moses, and spoke through the prophets." ${ }^{21}$ In the NT, God's mighty power is manifested through his rule, his kingdom. (1 Corinthians 4:19-20). Dynamis (power) is one of the characteristics of God's kingdom (Mark 9:1). In God's kingdom, all powers and authorities are and will be submitted to him (1 Cor 15:24 King James Version [KJV]). God is capable of raising us up from death (1 Cor 6:14). God is a source of authority and has all the power (Jude 1:25). What is different in the NT is the specific revelation of God and his power through the incarnate God, Jesus Christ, the "power of God," Messiah, Son of God, the expression of God, and one with God. Jesus was the one to whom authority and power belongs (Matt 28:18). As Foerster said, "The historical Jesus claims exousia within the limits of his commission, e.g., to forgive sins (Mark 2:10), to expel demons (Mark 3:15), and to teach (Matt 7:29; Mark 11:28; Matt 9:8; Luke 4:36)." ${ }^{22}$ His power was visible in his capability to heal or to raise

${ }^{20}$ Ibid., 275.

${ }^{21}$ Daniel L. Migliore, The Power of God and the gods of Power (Louisville, KY: Westminster John Knox Press, 2008), 48.

${ }^{22}$ W. Foerster, "exousia [power to act, authority]," in Theological Dictionary of the New Testament, 239. 
people from death (Luke 5:17). Jesus uses his works in performing miracles and forgiving sins as proof of his divine-origin, Messianic mission and divine authority.

God's power described in the Bible is kingly power, but liberating, redeeming, and prophetic, as well (Matt 6:13; 22:29). ${ }^{23}$ That power extends to the eternal future (Ps 90:2; Isa 26:4; Jer 10:10; Rev 11:15). Through God's power there is the promise of eternal life (Heb 7:16 KJV). God's power is expressed in the cleansing of our sins (Heb 1:3). By that power, accepted by faith, human beings are protected for salvation (1 Pet 1:5). That power is available for us to endure sufferings (2 Tim 1:8). True goodliness, not something formal, comes through the power of God (2 Tim 3:5). Even though that power is unlimited and is intrinsically a characteristic of God, as previously mentioned, God willingly limited and bounded that power. He created creatures with free will capable to question his existence and authority.

One of the unfortunate consequences of God's decision to give freedom to his creation was the conflict between the power and authority of God and the power and authority of the forces which Jesus labels as "the power of darkness" (Luke 22:53). That conflict is very present in the Scripture (Luke 12:5; Eph 2:2). While theodicy is not a topic of this study, in the conflict the Bible describes, the creation challenged the power

${ }^{23}$ Grundmann states: "Like all NT [New Testament] concepts, the NT concept of power receives its decisive impress from the fact of Christ. This fact is obviously linked with the OT [Old Testament] view of the Messiah, who is consistently related to the strength of God (cf. Is. 9:5; to be able dynamai 11:2; Ps. 110:2; Mic. 5:5). This strength is primarily kingly, but prophetic power is also involved (cf. Mic. 3:8; Acts 7:22 [Moses]; Lk. 1:17 [the Baptist]). The prophetic aspect achieves greater prominence in the NT (cf. Lk. 24:19). Yet Christ is more than a prophet endowed with power, his whole being is a unique one that is peculiarly determined by the power of God. This comes to expression in the parallelism of the Holy Spirit and the power of the Most High in the story of the virgin conception." 23 (W. Grundmann, "dynamis [ability, power]," in Theological Dictionary of the New Testament, 188-189.) 
of the creator and apparently accused God of abusing, or at least misusing his power and authority. The Scriptures describes God as not only all-powerful, but also perfect, good, and just. Hume did not challenge God's power, but rather, God's coexistence with evil: "A perfectly good and omnipotent God would not wish to create suffering and he would be able to prevent any suffering. But there is suffering, and an immense amount of it, in this world. Therefore, there is no good and omnipotent creator." ${ }^{24}$ The big question is why, despite God's power and his goodness, sin exists and is so prevalent on this earth and in the universe. It was already suggested that not using and applying power and authority when situations request it also present an abuse of power. While Tillich suggested that God's exists as Being-Itself (for us an incomprehensible realm) and prevents us from attaching attributes, such as omnipotence, to the power of Being, ${ }^{25}$ if the supreme God is omnipotent, ${ }^{26}$ then a solution is needed for the problem of the coexistence of evil with an all-powerful and all-loving God.

One possible defense of God's justice and goodness in the face of the existence of evil is proposed by two similar (although from different theological traditions) viewsthe warfare view and the great controversy view. ${ }^{27}$ Both assert that God's power was

\footnotetext{
${ }^{24}$ Hume; quoted in Atle Ottesen Søvik, The Problem of Evil and the Power of God (Boston: Brill, 2011), 39.

${ }^{25}$ Paul Tillich, Systematic Theology: Existence and The Christ, vol. 2, 3 vols. (Chicago, IL: University of Chicago, 1975).

${ }^{26}$ Similar to numerous other thinkers, Schweiker equalizes ultimate power and omnipotence with God: "Ultimate power, when it evokes gratitude and reverence, is identified as 'God' insofar as it respects and enhances finite reality." (William Schweiker, Power, Value, and Conviction: Theological Ethics in the Postmodern Age, 153.)

${ }^{27}$ The great controversy view is specific for Seventh-day Adventist theology (See: Seventh-day Adventists Believe... A Biblical Expositions of 27 Fundamental Doctrines (Silver
} 
challenged by the power of his creatures. ${ }^{28}$ Facing that challenge he did not abuse his power but rather chose not to use it in order to execute the complete and final solution for the problem of evil and in the process, to save the largest possible number of his fallen creatures. ${ }^{29}$ At the end of the book of Revelation, the author makes clear the emphasis on the finality and superiority of the power of God which will win the final victory in conflict with the powers of evil (Rev 19:1). God will ultimately use his omnipotent power to recreate the entire universe in its original state of harmony and happiness. Thereby, God's limitation is not a lack of power or strength, but rather his choice not to use the whole capacity of his strength and power because of his love and desire to help his creatures.

A discourse on God's power also reveals an interesting correlation between the practice of Christian leaders and theology. The leadership practices of Christian leaders are directly related to their theology. When theologians emphasize God's power more, their leadership practice is more autocratic, and a shift in theology is reflected in the

Springs, MD: Ministerial Association General Conference of Seventh-day Adventists, 1988), 98105; Richard Rice, Reign of God: An Introduction to Christian Theology from a Seventh-day Adventist Perspective, 2nd ed. (Berrien Springs, MI: Andrews University Press, 1997), 148-150.), while the spiritual warfare view is introduced in the theological work of Gregory A. Boyd (See: Gregory A. Boyd, God at War: The Bible \& Spiritual Conflict (Downers Grove, IL: InterVarsity Press, 1997).).

${ }^{28}$ Paul's claim of the existence of a power opposed to God: "The coming of the lawless one is according to the working of Satan, with all power, signs, and lying wonders (2 Thess 2:9). In Revelation the author uses word $\delta v$ vauı (dynamis) to describe both the power of God and also the power of the dragon - the devil. He, therefore, acknowledges that the devil posed and distributed power, too (Rev 13:2). Nevertheless, that power is inferior to the power of God.

${ }^{29}$ This idea is well presented in Jesus' parable of the weeds (Matt 13:24-30). In the parable, a man sows good seed in his field, but an enemy comes and sows tares. When the result becomes evident, the servants of the man ask his permission to go to take care of the weeds. He answers "No; lest while you are gathering up the tares, you may root up the wheat with them. Allow both to grow together until the harvest. (Matt 13:29-30)" 
leadership practice. One can conclude that our perception of God and his power will shape our leadership practice. However, whether the practice of church leaders reflects theological thinking on power, or their theology, and consequently, their practice is molded by the socio-political environment in which they live, or both factors are equally important, is less clear. The purpose of the following section is to understand the power of humans in the right relation to the power of God.

\section{Power of Human Beings - Power Received from God}

The discourse on the power of human beings in Christian theology is related to the doctrine of man, specifically to the nature of human beings. Richard Rice points out, referring to Reinhold Niebuhr, that human beings are their own biggest enigma. Human existence is so complex that despite all scientific advances, it is difficult to describe humans. Rice's description of basic human qualities begins with human limitations: "It is obvious, for example, that human beings are finite, that we have enormous limitations. At the same time, we are aware of these limitations, and in this awareness we go beyond them in some extent. ${ }^{30}$ In addition, he presents humans as individuals who find meaning as social beings living in communities, free and self-determined, who have responsibility and a feeling of responsibility, and are both good and evil.

The Bible acknowledges the power of human beings ( $2 \mathrm{Chr} 22: 9)$, or personal or physical strength of individuals (Gen 31:6). Power of humans is described as military power or power of the group (Joshua 17:17; Ezra 4:23; $1 \mathrm{Chr} 20: 1$ ). It is also political power or power of one human being over another (2 Kings 19:26; Esther 1:3; Ps 22:20).

\footnotetext{
${ }^{30}$ Richard Rice, Reign of God: An Introduction to Christian Theology from a Seventh-day Adventist Perspective, 116.
} 
Even though humans have power and can feel very powerful, God is the source of power and power is derived from him (Deut 8:17, 18). ${ }^{31}$ A certain level of dominion and power human beings possess are delegated by God. As created beings, humans are inferior not only to God but also to the other heavenly beings (Ps 8:4-6). Thereby, the power of human beings needs a right perspective-trusting in our own power is in vain.

While discussing these aspects of God's power form the wisdom tradition of faith, Hans-Ruedi Weber actually gives three suggestions on an appropriate use of the power of human beings: humans must be realistic regarding their power, human beings are the steward of power, and humans must acknowledge other powers and live in harmony with them. ${ }^{32}$ Similarly to Weber, Rice asserts that the power of human beings created in the image of God includes certain natural powers, dominion over creation but equality with other humans, and stewardship. Although humans are created in the image of God, Aquinas argues, that image does not imply equality with him, but rather some similarity to him. As God's creatures, humans are inferior to God. Calvin considers people as God's workmanship and as such, they must submit to his authority. Everything that they are and

\footnotetext{
${ }^{31}$ Christopher Wright emphasizes the authority of God, on which his power is based, derived from his identity and character. "So the reality of YHWH's character implies the authority for an ethic of imitation and reflection of that character in human behavior. We ought to behave in certain ways because that is what YHWH is like, and that reality is sufficient authority." (Christopher J. H. Wright, Old Testament Ethics for the People of God (Downers Grove, IL: InterVarsity Press, 2004), 460.) Humans are to follow that reality and use their power as imitators of God.

32 "...first, the sober and realistic attitude towards all human power; secondly, the human vocation to be responsible, mature stewards of power; and thirdly, the acknowledgment of the powers, the order and beauty with which God has endowed the whole of creation and with which human beings must live in harmony, lest they should destroy both themselves and God's creation." (Hans-Ruedi Weber, Power: Focus for a Biblical Theology, 77.)
} 
have they owe to him who is originator and source of all goodness. Therefore, human beings must allow God to exercise power over them.

But when addressing the use of power of one human being over another the Scripture labels the forceful use of power as oppression (Eccl 4:1). Very often oppression has been employed as a legitimate method derived from the authority of a person such as a king in order to control his dominion of power. That type of application of power is very hard do challenge (Eccl 8:4). In spite of legal justification, oppression is the abuse of power. Jürgen Moltmann describes the sad effects of oppression: "Oppression always has two sides... On the one side is the arrogant self-elevation of the exploiter, on the other the suffering of his victim. Oppression destroys humanity on both sides. The oppressor acts inhumanely, the victim is dehumanized." ${ }^{33}$ For Moltmann, the abuse of power negatively affects both the abuser and the abused. In order to be a free human being, both sides need liberation. Because of the "double effect" of power, men need an outward controlling mechanism for the application of power. Putting in place checks and balances is a method humans use to limit the power of leaders, and to prevent the misuse of that power.

Awareness of the fact that the power of men is limited and delegated might be another controlling mechanism for preventing the misuse of power.

Good example of an appropriate application of power of human beings is Paul's use of word Exousia-power to describe relations among humans based on their power and authority: "The wife does not have authority over her own body, but the husband does. And likewise the husband does not have authority over his own body, but the wife

\footnotetext{
${ }^{33}$ Jürgen Moltmann, Experiences in Theology: Ways and Forms of Christian Theology, trans. Margaret Kohl (Minneapolis, MN: Fortress Press, 2000), 185.
} 
does (1 Cor 7:4). Paul equalized the rights, value, authority, and power of husband and wife by giving authority of one to another.

The Bible also places humans in the position of a custodian or steward of God's goods, and not their owner. That stewardship of human beings is based on delegation of God's authority to them (Matt 9:8). That delegation is seen through human superiority over nature. While human beings manage and use this world, they have responsibility to God, Creator of everything.

Despite the inferiority of human power-its "passiveness"-Brueggemann argues that human beings are to exercise their power but within "the bounds of Yahweh's mandate." 34 Just as the power of the president of the United States derives from his position as president and his authority comes from election through which the people give him the right to lead them, the power of spiritual leader comes from a mandate received from God. The power of the spiritual leader (in this case, a minister) involves call, position, expertise, and charisma. ${ }^{35}$ While expertise and charisma (based on education, talents, or personality) are important qualities for all types of leaders, call and position are particular for Christian leadership. Call is the result of God's invitation, and implies service and submission to the rightful owner of power-God. Position points to the rightful application of the service and appropriate representation of God's power. 518.

${ }^{34}$ Walter Brueggemann, Theology of the Old Testament: Testimony, Dispute, Advocacy,

${ }^{35}$ According to the questionnaire results of the members of the Richard Baxter Institute for Ministry stated in a 1996 study by Paul Beasley-Murray. (Paul Beasley-Murray, Power for God's Sake: Power and Abuse in the Local Church, 88, 89.) 
Therefore, the authority and power of spiritual leaders is based on a faithful imitation of the One who gave them a mandate and authorized their position, following his leadership.

Freedom is another important dimension of inferior human power. ${ }^{36}$ It is one of the greatest wants of humankind. Its expressions-free will and freedom of choicedetermine us as humans. Although Brueggemann argues that unfettered, autonomous freedom does not exist, ${ }^{37}$ Kierkegaard asserts that God gives us independence and freedom. These seemingly opposing views stem from Brueggemann's emphasis on God being in charge and giving a mandate, versus Kierkegaard's depiction of God who does not always intervene in human affairs, and gives us independence and freedom, even in our application of power. According to Kierkegaard, "The greatest good, after all, that can be done for a being, greater than anything else that one can do for it, is to make it free. In order to do just that, omnipotence is required." 38 Kierkegaard argues that the ability to make someone free and liberate him/her requires possessing and exercising power. A limited human being cannot simultaneously withdraw itself and give itself away. Finite, limited power cannot impart freedom to another being, ${ }^{39}$ whereas

\footnotetext{
${ }^{36}$ Keith Hyde indicates that "For Kierkegaard, one of the greatest expressions of God's love - and equally expressive of God's supreme otherness and utter incontestability - is human freedom." (J. Keith Hyde, Concepts of Power in Kierkegaard and Nietzsche (Farnham, England: Ashgate, 2010), 86.)

${ }^{37}$ In his depiction of the inferiority of human power Brueggemann says: "The truth of the testimony, 'Yahweh who commands,' is that unfettered, autonomous freedom is in fact not available. Life is fundamentally relational, and the One who investigates and stands as the source of life's relatedness is the God who commands." (Walter Brueggemann, Theology of the Old Testament: Testimony, Dispute, Advocacy, 200.)

${ }^{38}$ Søren Kierkegaard, The Moment and Late Writings, ed. and trans. Howard V. Hong and Edna H. Hong (Princeton, NJ: Princeton University Press, 1998), 390.

${ }^{39}$ Kierkegaard recognizes the problem in a human attempt to make another human free: "This is why one human being cannot make another person wholly free, because the one who has
} 
omnipotent power alone can make another being independent or free by a continual withdrawal of omnipotence.

The coexistence of power and freedom is complex. Humans are created equal. However, when something needs to be done, some are leaders and some are followers. The reasons for such are pragmatic. We have different functions, talents, positions, mandates, and consequently, authority. Some level of order and organization is necessary for any group to be effective. That duality_-being equal in value and having different roles, and consequently, different positions of hierarchy based on the lead/follow relationship — makes power complex and relational. According to Kierkegaard, God's power (his omnipotence) is controlled by his goodness, which he confirmed by laying aside his power to make us free and independent. Humans have never possessed omnipotence, and their goodness has been impaired with the emergence of sin, which has affected the relationship between human power and human freedom. The power of one person might collide with the power of another person, affecting freedom of the persons. Sadly, the freedom to use power creates the greatest abuses of power possible.

Nevertheless, the portrait of the power of humans is incomplete without recognizing the positive purpose of the power received from God. Andy Crouch describes power as a gift: "Power is for flourishing. This means power is a gift worth asking for, seeking and — should we receive it - stewarding." ${ }^{40}$ This gift of power is God's gift, given for the purpose of affecting those who surround us, to enhance their

power is himself captive in having it and therefore continually has a wrong relationship to the one whom he wants to make free." (ibid., 391.)

${ }^{40}$ Andy Crouch, Playing God: Redeeming the Gift of Power (Downers Grove, IL: IVP Books, 2013). 
lives and our life. If properly used, this gift can positively impact the lives of those who are affected by it. It is a necessary and God-given tool to achieve such goals.

Spiritual leaders must be humble because the power they possess is God's gift, not proof of their value. That fact helps them exercise power in accordance with the will of its rightful owner. The application is obvious: the responsibility of spiritual leaders is to reflect the real source of power, which is God. Their decisions, their behavior, and their methods must not only reflect them, but also reflect God and his will. They are not the ultimate authority and power; God is. ${ }^{41}$

Forbes indicates, "The writings of the prophets sustain this theme: It is sinful and foolish to pursue power. . The pursuit of power stems from a desire to be unlike the rest of the earth. ${ }^{, 42}$ Possessing power simply for the sake of power is the result of human selfishness, the human desire to be special and honored. By realizing that their power is not God's power and that they must submit their limited power to him, spiritual leaders can put things in the right perspective. This will help them in appropriately applying and using power and not wasting their time preserving their own power, position of power, or personal benefits of power. Instead of focusing on themselves, they can concentrate on the needs of those they lead.

Doing what God, the real source of power, wants and following his instruction will help the spiritual leader perform what is good and right and protect him from the

\footnotetext{
${ }^{41}$ Stortz eloquently describes: "This person of God informs how one exercises 'power over.' A God who sustains, surprises, reveals is also a God who enables and requires the kind of discernment necessary to distinguish how one exercises 'power within.' A God with us 'Emmanuel,' who befriends, comforts, and challenges, is also a God who shows us how to befriend one another. This person of God informs how one exercises 'power with."' (Martha Ellen Stortz, PastorPower, 42.)

${ }^{42}$ Cheryl Forbes, The Religion of Power, 112-113. (see also Isa 14:10-12).
} 
corruptive nature of power. In that regard, following Jesus' example becomes the primary priority for effective and appropriate use of power among Christian leaders.

\section{Jesus as Example - Powerless Power}

The discrepancy between the power of God and the power of humans calls for a solution harmonizing those two powers. As Migliore indicates, Jesus' unique use (or lack of use) of power is the model of power use for Christian leaders. ${ }^{43}$ However, Jesus is more than just an example; he is also the One who gives power to human beings.

While in the previous sections the biblical discourse on power included all biblical traditions, the discourse on Jesus' power is obviously limited on the NT tradition. The quoted authors are chosen based on the importance of their ideas for this study. Gerd Theissen explains that the Jesus tradition portrays Jesus as the One with authority and power, while simultaneously powerless, a portrayal with an obvious dichotomy. ${ }^{44} \mathrm{He}$ heals, controls nature, speaks with authority, cleanses the temple, and has followers, yet is poor, possesses no earthly property, does not have any official political power, and is falsely accused and ultimately crucified. According to Forbes Jesus seemed indifferent to the issue of power, "Jesus was uninterested in the politics of his day. He did not want power or its gifts. To use the language of psychology, Jesus knew who he was and what his role was to be. He already had a name: Son of God, Son of Man. He was unconcerned

43،"All of our images of God must be radically revised in the light of Jesus Christ the crucified and risen Lord. He is the central clue, the key that unlocks the right understanding of authentic divine power and fruitful human power." (Daniel L. Migliore, The Power of God and the gods of Power, 72-73.)

${ }^{44}$ Gerd Theissen, "The Ambivalence of Power in Early Christianity," in Power, Powerlessness, and the Divine: New Inquires in the Bible and Theology, ed. Cynthia L. Rigby (Atlanta, GA: Scholars Press, 1997). 
with acquiring his own space or striving for authority." ${ }^{45}$ Nevertheless, he used power whenever someone was in need, asked him for help, or when he was protecting the authority and dignity of God's institutions and God's authority. He used his power for the powerless as well. That unique application of power was a combination of (limitless) power and powerlessness, which culminated on the cross. Weber depicts that uniqueness of Jesus' power use as "the paradox of the crucified king."

The Pauline tradition does not differ from the Jesus tradition on the issue of power, except that the Jesus tradition views Jesus as a man among other men, whereas the kerygmatic Jesus, presented by the Pauline tradition, is a God who pre-existed, whose earthly existence is a temporary phase followed with an exaltation of the original state of power. As an introduction for his discussion of the biblical tradition on the question of how Jesus used power, Theissen discusses two conflicting theoretical models of understanding history: conflict and integration. The theory of conflict considers history as a struggle over the distribution of three goods: power control (rulership), property, and education (wisdom). The theory of integration looks at history as a continuous attempt to create cooperation among people within a framework of social order. Using the conflicting theory paradigm Theissen proposes, "Paul is questioning the distribution of these goods [power control, property, and education] by unfolding his kerygmatic image of Christ." ${ }^{\prime 47}$ Jesus did not merely question, but challenged the political system of power

\footnotetext{
${ }^{45}$ Cheryl Forbes, The Religion of Power, 114.

${ }^{46}$ Hans-Ruedi Weber, Power: Focus for a Biblical Theology, 64.

${ }^{47}$ Gerd Theissen, "The Ambivalence of Power in Early Christianity," in Power, Powerlessness, and the Divine: New Inquires in the Bible and Theology, 29.
} 
with his example of redistribution of power ${ }^{48} \mathrm{He}$ helped the powerless, the poor, and the uneducated, spent time with them, and empowered them with his message of the Kingdom that belonged to them. The path he took exceeded the comprehension of those who witnessed the life of the incarnate God. Jesus did not merely preach; he put himself in the same powerless position.

Joseph Hellerman discusses the kerygmatic Jesus Paul depicts in Phil 2:5-8, with emphasis on Jesus' use of power and his attitude toward socio-political powers. Jesus' practice was a challenge to societal expectations regarding the use of power, as was his call to humbleness and rejection of power. "In 2:7 Paul refers to Jesus as a 'slave' (doulos), in a context that can hardly refer to anything but the abject social status of a Greco-Roman slave."49 Paul's use of doulos was a challenge for the social-pecking order, a use that emphasizes the depth of Jesus' humiliation.

To explain how deeply Jesus humiliated himself, Hellerman uses the biblical narrative to indicate that Paul presented the humiliation of Jesus in three status levels: first, equality with God, second, incarnation — taking the form of a slave and the likeness of a man, and third, crucifixion - humbling obedience to the point of death, even on the cross. These three stages correspond to the three levels of social status of Paul's contemporaries, which make the scandal of the crucified God understandable for them. The powerlessness of Jesus is reflected in the total humiliation of the crucified slave, but

\footnotetext{
${ }^{48}$ Theißen asserts, "God himself takes on powerlessness, poverty and foolishness in Christ - and thus de-legitimizes the distribution of power, property, and education in society." (ibid., 30).

${ }^{49}$ Joseph H. Hellerman, Embracing Shared Ministry: Power and Status in the Early Church and Why It Matters Today (Grand Rapids, MI: Kregel Academic, 2013), 126.
} 
underlined by the fact that he reached that point from the position of an all-powerful Creator and Ruler of the universe.

The most intriguing part of Jesus' powerlessness is that, even in his worst humiliation, he was not without power. The text in Philippians is part of a discourse on kenosis, which discusses one of the key words Paul uses in Phil 2:7 to describe Jesus' path from the throne of God to the cross - the verb кєvó $\omega$ (kenoo), which means "to empty." That verb includes the meaning of self-emptying according to his own will. Therefore, Paul indicates that Jesus was powerless, not because he did not have power, but because he chose not to use ("emptied" himself of) the power he had. Campolo explains, "In Jesus, God expressed Himself in a way that is shocking. He expressed Himself as a God of love and in the process set aside power." ${ }^{50}$

Paul does not say that the humiliated and crucified Jesus will permanently retain his powerless position. He is One who receives authority and power from his father. As Hellerman points out:

In a shocking act of status reversal, however, God suddenly and irretrievably subverted the social values of the dominant culture when he unequivocally affirmed Jesus' counterintuitive approach to power and privilege by exalting him to the highest place, thereby assuring that Jesus - not Caesar - would be publicly acknowledged as "Lord" by every living creature $(2: 9-11){ }^{51}$

What can be learned from Paul's two aspects of power of the kerygmatic Christthe one in which Jesus accepted total powerlessness, and the other in which he is the ruler of the universe? For Jesus, power was a tool for making positive changes in all of creation. He used his power in the service of others, and his use of power was a challenge

${ }^{50}$ Anthony Campolo Jr., The Power Delusion, 86.

${ }^{51}$ Joseph H. Hellerman, Embracing Shared Ministry: Power and Status in the Early Church and Why It Matters Today, 140. 
to commonly accepted social standards. However, he never hesitated to put power aside when doing so would have a more positive effect. His powerlessness was not the result of weakness, but of a willingness to disuse power, which may actually require more internal strength than simply exercising power and authority.

For Jesus, as for us,$^{52}$ the greatest temptation was to use the power that he possessed for selfish purposes. The devil tempted Jesus to show his power and to use it for himself. Forbes depicts Jesus' temptations as a struggle with power:

Satan tempted him with power. Obviously, the second temptation-offering to give Jesus all the kingdoms of the world, 'all authority and splendor' - is a direct temptation to grasp power. The other two temptations are for Jesus to show his power - to create food and to overcome death. They are an appeal to use the power Satan knew Jesus already possessed. Jesus rejected all three. ${ }^{53}$

Jesus overcame those temptations. Martyn Percy stated, "Jesus is both a testament to the power of God and also to the willingness of God to give up power." ${ }^{54}$ Controlling power is one of the greatest challenges to the use of power, and Jesus' answer to that challenge was giving up his power.

The Johannine tradition presents Jesus who became victorious through the crucifixion, winning by losing his life, and the resurrection gives him the right and authority over all power, including the "ruler of this world" who is the devil. Despite the common perception, Christian leaders do not always need to exercise their power to positively affect their followers. Putting power aside can be the most effective method in

\footnotetext{
${ }^{52}$ What is different is that because man possesses unmeasurably less power, the temptations of humans are proportionally smaller.

${ }^{53}$ Cheryl Forbes, The Religion of Power, 119.

${ }^{54}$ Paul Beasley-Murray, Power for God's Sake: Power and Abuse in the Local Church, xiii.
} 
certain situations, portrayed in the example of Jesus. This application of power is counter-cultural. "Contrary to the advice of those who know how to acquire and use power, Jesus demands unself-serving behavior. There is no room in the gospel for climbing the rungs of the ladder of power." ${ }^{55}$ His use of power was free of selfishness. He rejected the use of power for himself when he was tempted in the wilderness, when people wanted to make him a king, ${ }^{56}$ or when he was captured and crucified.

Sociology presents powerlessness in leadership as weakness, and powerlessness in the social setting as weakness of the social structure, injustice based on and caused by inequality, or the failure of society (for lack of opportunity to provide all members of society with the opportunity to pursue happiness). However, in his discussion on the anawim tradition in the Bible, Weber presents the intriguing dimension of powerlessness as an opportunity for God to empower human beings:

With their empty hands the anawim can offer nothing other than themselves. In the life of the martyrs this becomes literally true. Such total availability characterizes all who have nothing to give except themselves, who have committed their cause to the Lord (Ps 22:8; Jer 20:12). This poverty of empty hands is the channel for God's power. $^{57}$

In the Bible, powerlessness is often described as a strength, an opportunity for God to intervene. Because the powerless ones rely on God, he can act and empower

${ }^{55}$ Cheryl Forbes, The Religion of Power, 115.

${ }^{56}$ Forbes said, "God, then, detests what men value. He condemns those who strive for fame or fortune. Jesus rejects the use of power as we have come to understand it. When, after feeding the five thousand, he realizes that people 'intended to come and make him king by force,' he goes into the hills alone (John 6:15).” (ibid., 116.)

${ }^{57}$ Hans-Ruedi Weber, Power: Focus for a Biblical Theology, 126. 
them. The issue of powerlessness also includes pictures of God as a protector of the poor and humble, and the Messiah as suffering and poor.

The ultimate model incorporating notions of the powerless power of Jesus would be the picture of the shepherd and sheep, combined with the picture of Christ as the Lamb of God. ${ }^{58}$ Just as a good shepherd sacrifices himself for his sheep, Jesus sacrificed himself for humankind. While Jesus presented himself as the shepherd who cares for his sheep, the one who used his power for others, when his interest was in question, he behaved as a lamb. He allowed others to exercise power over him, to make him powerless.

That relationship between God's power and powerlessness can inform the leadership of Christian leaders and counteract the gravitation of spiritual leadership toward the authoritarian and hierarchical approach. Christian leaders, as followers of Jesus, must be powerless (emptied) as he was, relying on the power of their Shepherd in their attempt to influence the world. Jesus did not win over sin by conquering opposing forces by using his power, but by emptying himself of power and allowing others to humiliate and crucify him. Likewise, Christian leaders should use the power they have received for the good and benefit of others, and should ignore, or at least diminish, their own interest in the application of power.

${ }^{58}$ Forbes suggests, "Jesus used sheep as the symbol for His people. What are sheep like? First, they are harmless. They are defenseless. They are powerless... Jesus Christ says that he sends us out into the world as sheep, not as lions or foxes or wolves. That is how powerless we are to be." (Cheryl Forbes, The Religion of Power, 120.) 


\section{Summary}

Power is God's intrinsic quality. All power belongs to him; he is its rightful owner, and he is the ultimate source of power. God willingly limited power with love, and for the benefit of his creatures. His steadfast love balances that power. He is the benevolent ruler of the universe - power and goodness at once.

In contrast to God, humans are limited, and their power is limited as well. They have power insofar as God gives it to them. The power of humans is a gift from God with a positive purpose. Human power, therefore, needs to be properly related to the power of God. Humans have to be realistic, aware of their limits, they have to use power responsibly-as stewards of delegated power, and they have to live in harmony with others.

Thus, Christian leaders have to submit to the power of God, allow God to exercise his power over them and use received authority in accordance with the will of the rightful owner. Under those conditions humans have a right and responsibility of using their power as the custodian of the gift. The use of it is limited by the human freedom received from God. All humans are created equal, and an existence of the leadership positions is the result of a practical need for organization and order. Abuses of power are the results of a disruption of the correct relationships between the powers. Human power (and abuse as well) needs to be controlled by checks and balances and has to be placed in the right perspective.

That perspective can be deducted from Jesus' example. He was at the same time all-powerful and powerless. There was no been a need for him to prove or show how powerful he has been. He never used his power for selfish purposes. He was powerless for himself but all powerful for the powerless. The abuse of power is when an almost 
powerless steward of God's power presents himself as all powerful and use power for selfish purposes. Jesus' powerlessness was not for the lack of power, but by choice. That paradigm of using power, presented in the parable of the good shepherd, is supposed to be followed by humans.

Because of the inadequacy of applying in the church commonly accepted power models and leadership styles from politics, business, or society, this study seeks for a potentially ideal Christian model of leadership based on the biblical views of power. Thus, after discussing ethical issues related to the use of power in the following section, the end of this chapter will propose the model and suggest the pattern to discern a legitimate use of power from the abuses. A detection and analysis of the abuses of power in the fourth chapter will use that pattern.

\section{Ethics of Using Power}

Philosophical ethics, from the age of Socrates, has concentrated on what is good (what constitutes a good person) and what is right. ${ }^{59}$ Answering those questions is important for ethics of power as well. Humans have been concerned with the ethics of their leaders and how they use their power because a leader's ethics has determined what kind of leader he/she is. As Northouse stated, "In regard to leadership, ethics has to do with what leaders do and who leaders are. It is concerned with the nature of leaders' behavior and their virtuousness. In any decision-making situation, ethical issues are either

${ }^{59}$ See Stanley J. Grenz, The Moral Quest: Foundations of Christian Ethics (Downers Grove, IL: InterVarsity Press, 1997), 23-24. 
implicitly or explicitly involved." ${ }^{90}$ The legitimate exercise of power is a crucial and significant part of leadership. As such, it has a substantial moral dimension.

The analysis and evaluation of power are the tasks of leadership ethics. Ethical leadership is part of leadership theory, which is concerned with establishing a scientific foundation for applying ethics in leadership. Although ethics has always been an important part of leadership, and the ethics of leaders has always been a concern of human beings, research on ethical leadership is still in an early stage of development. Northouse observes that the earliest writings that particularly focus on leadership ethics appeared as recently as $1996 .{ }^{61}$

\section{Ethical Theories of Leadership}

Northouse suggests, "ethical theories are about both the actions of leaders and who they are as people." ${ }^{\prime 2}$ Consequently, there are two major domains of ethical leadership: "theories about leaders' conduct and theories about leaders' character." 63

\section{Theories About the Conduct of a Leader}

According to the first domain, the conduct of a leader is determined by either the consequences of his/her actions or decisions or by a moral obligation to do what is right. Therefore, the conduct of the leader is either teleological or deontological in nature.

\footnotetext{
${ }^{60}$ Peter G. Northouse, Leadership: Theory and Practice, 4th. ed. 342.

${ }^{61}$ Ibid., 341.

${ }^{62}$ Ibid., 343.

${ }^{63}$ See ibid., 343, 344.
} 
The teleological approach includes the possibility that the actions of a leader can fall into the realm of ethical egoism, utilitarianism, or altruism. In other words, even though the morality of a leader's conduct is determined by the outcome of his/her actions, the outcome is molded by the motivation for the actions. That motivation is the greatest good for himself/herself (ethical egoism), the greatest good for the greatest number (utilitarianism), or the greatest good for others (ethical altruism).

Utilitarianism is a normative moral theory based on the principle of utility or usefulness of an action. Jeremy Bentham and John Stuart Mill proposed that its goal (telos) is the greatest happiness for the greatest number. According to the utilitarian view, "actions are right or wrong depending upon whether or not they further progress toward an end (telos) or goal that is worth striving for ... The ends, or consequences, justify the means you choose." 64 All teleological approaches are based on the principle of utility, but they are differentiated by who benefits from that utility (myself, others, or the greatest number).

Although Christianity is concerned with the ultimate end - the kingdom of Godfor Christians, that end alone is not a justification for the use of bad means in the process of achieving that goal. Stassen and Gushee expressed the Christian view on ethics:

We believe a Jesus-centered ethic takes divine commands seriously and is indeed vigorously deontological. But it understands the mandates and teachings of Jesus to be gracious and authoritative instructions concerning how to do the will of God (deontological) and how to participate in the coming of the kingdom of God (teleological). ${ }^{65}$

\footnotetext{
${ }^{64}$ Glen Harold Stassen and David P. Gushee, Kingdom Ethics: Following Jesus in Contemporary Context (Downers Grove, IL: InterVarsity Press, 2003), 119.
}

${ }^{65}$ Ibid., 121. 
Reconciling the prevalent pragmatic and utilitarian use of power, which includes many abuses of power in today's political and business world, with the Christian ideals of love and sacrifice is almost impossible. Unfortunately, many politicians, businessmen, and sometimes, even Christian leaders try to apply them together.

The deontological moral theory regards the actions of leaders as morally correct if they fulfill their duty to do what is right despite the consequences. It studies the relationship between duty and morality. Immanuel Kant derives his arguments for deontological ethics from human reason and defines the ultimate good as follows: "There is nothing it is possible to think of anywhere in the world, or indeed anything at all outside it, that can be held to be good without limitation, excepting only a good will." He proposes the existence of an intrinsic goodness regardless of the ultimate end. ${ }^{67}$ Based on deontological ethics, an action is morally good because of the intrinsic goodness of the action itself. Whether the product of an action is good is irrelevant. Motives make an action wrong or right.

Thereby, deontological ethics is primarily concerned with intentions and motives. Kant defines that obligation to follow duties as the categorical imperative: "The categorical imperative is thus only a single one, and specifically this: Act only in

\footnotetext{
${ }^{66}$ Immanuel Kant, Groundwork for the Metaphysics of Morals, ed. Allen W. Wood, Rethinking the Western Tradition. (New Haven: Yale University Press, 2002), 9, http://ezproxy.cc.andrews.edu/login?URL=http://site.ebrary.com/lib/andrews/Doc?id=10170770.

${ }^{67}$ Kant: "The good will is good not through what it effects or accomplishes, not through its efficacy for attaining any intended end, but only through its willing, i.e., good in itself, and considered for itself. .." (ibid., 10.)
} 
accordance with that maxim through which you can at the same time will that it become a universal law. "68

Consequently, the actions of leaders depend on their understanding of what is right. Therefore, the ultimate goal of a leader is to behave according to principle, regardless of the final result. Such a perspective focuses on the actions of leaders and their obligation to do what is right.

\section{Theories About the Character of a Leader}

The second domain of ethical leadership is concerned with the character of the leader. It is not limited to a leader's behavior in public discourse, but is also concerned with the inherent complexity of attributes that determines a person's moral and ethical actions. Those theories are virtue-based theories and are concerned with who leaders are as persons. Al Gini asserts, "the quality of leadership can be measured only by what a leader intends, values, or stands for-in other words, by character. In Character:

America's Search for Leadership, Gail Sheehy argues, as did Aristotle before her that "character is the most crucial and most elusive element of leadership."

Virtue ethics is a moral theory that emphasizes the role of virtue and character rather than the consequence of the act or duty. It is teleological in nature because it is concerned with the ultimate goal and purpose of life ${ }^{70}$ while differing from

\footnotetext{
${ }^{68}$ Ibid., 37.
}

${ }^{69} \mathrm{Al}$ Gini, My Job, My Self: Work and the Creation of the Modern Individual (New York: Routledge, 2000), 162.

${ }^{70 "}$ "Virtue* (arete), which is defined as excellence* in fulfilling one's proper task or purpose." ("Virtue," in The Westminster Dictionary of Christian Ethics, ed. James F. Childress and John Macquarrie (Philadelphia: Westminster Press, 1986).) 
utilitarianism, which emphasizes the goal as a justification of the means. Virtue ethics instead emphasizes the means to achieve those goals-virtues - and how they shape character, and ultimately who we are. Will Durant describes Aristotle's ethics: "We are what we repeatedly do." ${ }^{71}$ Actions matter and they define us. ${ }^{72}$

According to Aristotle, virtue is the most important means of achieving happiness. Virtues are a pathway to happiness - the "ultimate" good. They are not the

${ }^{71}$ Will Durant, The Story of Philosophy: The Lives and Opinions of the Greater Philosophers of the Western World, 2d ed. (New York: Simon and Schuster, 1961), 61.

${ }^{72}$ The following discourse clarifies the complex ideas of Aristotle's virtue ethics:

Aristotle in his Nicomachean Ethics strives to answer the question: What is the good? The good for him is something that we all desire. An additional question is whether that "good" is actually good or just appears to be good, or whether it is moral or not. Aristotle is also aware that we desire certain things for the sake of other things and we desire certain things for their own sake. "So if what is done has some end that we want for its own sake, and everything else we want is for the sake of this end; and if we do not choose everything for the sake of something else (because this would lead to an infinite progression, making our desire fruitless and vain), then clearly this will be the good, indeed the chief good." (Aristotle, Nicomachean Ethics, ed. and trans. Roger Crisp (NY: Cambridge University Press, 2000), 4.)

Aristotle believes in the good that is the end of desire or some ultimate (chief) good. He rejects identifying that ultimate good with money, honor, or pleasure. Humans believe that by achieving that good they will attain the desired end.

Thomas Morris states: “... Aristotle had the insight that beneath all the surface differences in what we seem to chase, everyone in this life is really after the same thing: happiness." (Thomas V. Morris, If Aristotle ran General Motors: The New Soul of Business, 1 st ed. (New York: Henry Holt and Co., 1997), 10.)

The real question then becomes "what is happiness?" Aristotle uses the word Eudaimonia, which can be translated as blessedness, happiness, prosperity. Eudaimonia "is the state of being well and doing well in being well, of a man's being well-favored himself and in relation to the divine." (Alasdair C. MacIntyre, After Virtue: A Study in Moral Theory, 3rd ed. (South Bend, IN: University of Notre Dame Press, 2007), 148.)

Therefore, happiness is not merely a temporary joy or excitement, but rather a state of blessedness caused by satisfaction that comes from doing what is right. According to Peter Kraft's interpretation ${ }^{72}$ of Aristotle's ethics, happiness must satisfy three criteria: it is dependent on how good you are, it happens by choice (not chance), and it is lasting and not temporary. 
goal, but the means. As Durant comments: "we do not act rightly because we have virtue or excellence, but we rather have these because we have acted rightly."73

The difference among us is what we consider to be good, and what we believe will bring us happiness. As Blaise Pascal asserted:

All men seek happiness. This is without exception. Whatever different means they employ, they all tend to this end. The cause of some going to war, and of others avoiding it, is the same desire in both, attended with different views. The will never takes the least step but to this object. This is the motive of every action of every man, even of those who hang themselves. ${ }^{74}$

Motives are crucial aspects of power use that are typically not obvious. Although leaders typically conceal them behind secondary reasons (or excuses), they determine the direction and type of leadership leaders will apply. An analysis of power abuse attempts to recognize motives to determine when such abuse occurred.

Another important notion of virtue ethics related to the issue of power is the principle of the golden mean between two extremes. "According to Aristotle, virtue is a mean between two extremes, both of which are vices - either excess or deficiency (or defect)." ${ }^{.75}$ That mean is not the mathematical mean between two extremes, but a moral choice that requires wisdom to do what is right. This implies that a virtuous leader will do what is right, apply the right amount and type of power in his/her leadership, and avoid vices, that is, abuses that can be excessive or deficient, including the extreme use of power, or not using power when it is needed.

${ }^{73}$ Will Durant, The Story of Philosophy: The Lives and Opinions of the Greater Philosophers of the Western World, 61.

${ }^{74}$ Thomas V. Morris, If Aristotle ran General Motors: The New Soul of Business, 10.

${ }^{75}$ Jacques P. Thiroux, Ethics: Theory and Practice, 6th ed. (Upper Saddle River, NJ: Prentice Hall, 1998), 69. 
Virtue ethics applied in Christian leadership goes beyond what is visible. We are what we are, not only when making decisions and acting in a manner that is visible to all, when it can benefit us personally, or when it is in the best interest of others, but also when nobody sees us and when there is no visible benefit or reward for our decisions or behavior. The power of a leader is affected by his/her position, decisions, and actions, and also by his/her personality and who he/she is.

Although the leader's character is unimportant in some leadership positions, ${ }^{76}$ in the realm of Christian leadership, it is of essential importance. ${ }^{77}$ A Christian leader cares about traits of his character and cherishes Christian virtues. Ignoring those virtues or being corrupted by vices is an abuse of power.

\section{Principle-centered Leadership}

In addition to theories on the conduct and character of leaders, Stephen Covey introduced "principle-centered leadership." "Principle-centered leadership introduces a new paradigm — that we center our lives and our leadership of organizations and people on certain 'true north' principles." 78 Our leadership is determined by the principles we follow. They shape our priorities, methods, decisions, our conduct, and character.

\footnotetext{
${ }^{76}$ Such examples are observable in business leadership: If a leader makes good decisions for the corporation, if the company is prosperous and everyone benefits from such leadership, most likely no one will question the leader's private life, such as infidelity to a wife or husband.

${ }^{77}$ Gini indicated, "For leadership, Sheehy argued, character is fundamental and prophetic. The 'issues [of leadership] are today and will change in time. Character is what was yesterday and will be tomorrow.' She believes character establishes both our day-to-day demeanor and our destiny. Therefore, it is not only useful but essential to examine the character of those who desire to lead us." (Al Gini, My Job, My Self: Work and the Creation of the Modern Individual, 162.)

${ }^{78}$ Stephen R. Covey, Principle-Centered Leadership, 19.
} 
Therefore, a distinction among leaders can be made based on how well they apply true principles in their leadership. Covey suggested some universal and self-evident principles to follow and apply to leadership. "Our effectiveness is predicated upon certain inviolate principles - natural laws in the human dimension that are just as real, just as unchanging, as laws such as gravity are in the physical dimension." 79 Covey named those principles as fairness, equity, justice, integrity, honesty, and trust. ${ }^{80}$ Even though the existence of those principles is observable, the problem is that their interpretation and definition is highly affected by culture, society, beliefs, and ideology. A lack of universal agreement about "true north" principles is an obvious problem. According to Christianity, the "true north" principle would be following the teaching of Scripture and the example of the incarnate God, Jesus Christ.

Covey proposed that the best approach in the assessment of principle-centered leadership is to examine why people follow leaders. ${ }^{81}$ According to this measurement, he suggests three types of leadership that may be differentiated by the type of power leaders have over followers: coercive power, utility power, and legitimate power. This division has obvious similarities to the previously mentioned types of power: power over, power within, and power with. On the level of coercive power, individuals follow out of fear.

${ }^{79}$ Ibid., 18.

${ }^{80} \mathrm{Ibid}$. Furthermore, he indicated, "principles are not invented by us or by society; they are the laws of the universe that pertain to human relationships and human organizations. They are part of the human condition, consciousness, and conscience." (ibid.) "Principles are selfevident, self-validating natural laws. They don't change or shift. . . Principles apply at all times in all places. They surface in the form of values, ideas, norms, and teachings that uplift, ennoble, fulfill, empower, and inspire people. The lesson of history is that to the degree people and civilizations have operated in harmony with correct principles, they have prospered" (ibid.)

${ }^{81}$ See ibid., 101-108. 
When utility power is exercised, individuals follow because they expect some personal benefit from following the leader. A third type is based on the trust and rightful authority leaders possess. Their followers are committed, trusting, and hold them in the highest respect. From the ethical perspective, leadership that is based on legitimate power is the most desired type of leadership because it is based on positive motivation and stimulation rather than on fear or selfish interest. Legitimate power is related to the character and conduct of the leader.

This dissertation's analysis of power abuse in the case of kingly power is based on assessing both the character and conduct of observed leaders. In that assessment, it will be very important to observe how honestly these leaders followed principles. Therefore, questions of did they use legitimate power and why people followed them are crucial.

\section{Components of Ethical Leadership}

In his discourse on ethical leadership, Robert Starratt suggested that ethical leadership includes three main components: responsibility, authenticity, and presence. ${ }^{82}$

\section{Responsibility}

Every leadership position comes with responsibility, which consists of two main orientations. The first orientation is judging the leader's morality based on the past actions of the leader. The leader is accountable and must answer as to whether and why

\footnotetext{
${ }^{82}$ Robert J. Starratt, Ethical Leadership, Jossey-Bass Leadership Library in Education. (San Francisco: Jossey-Bass, 2004).
} 
he performed an action. This orientation is concerned with the past acts of the leader and the morality of the acts. ${ }^{83}$

The second orientation of responsibility relates to the current conduct of the leader. A leader in is assumed to act in a moral manner with respect to moral principles, as Starratt stated, to “. . . perform as a morally responsible agent." ${ }^{84}$ A leader's actions are morally justified if they reflect leader's role in responsible manner. ${ }^{85}$

\section{Authenticity}

Authenticity is based on the singularity of every human being. Each person and his/her character is unique, hence every leader is unique. Charles Taylor suggested a "certain way of being human that is my way. I am called upon to live my life in this way,

\footnotetext{
${ }^{83}$ Starratt commented that "the first orientation enjoys an ancient heritage going back to the Hebrew Scriptures (Brueggemann, 2001) and to Aristotle, Epicurus, Cicero, Augustine, Erasmus, Luther, as well as the later discussions of Hume, Kant, and Schopenhauer (Birnbacher, 2001). This orientation is what Jonsen (1968) refers to as the responsibility of attribution, the 'holding responsible for the commission of an act' or what Birnbacher calls the ex post responsibility (ex post, from Latin, is usually expressed as ex post facto, which is translated as 'after the fact,' or, more loosely, 'from the perspective of a past event')." (ibid., 45-46.)

${ }^{84}$ Ibid., 47.

${ }^{85}$ Starratt indicated, "This second orientation to responsibility is more recent in origin and development than the first orientation is. The English philosopher John Locke, in his Two Treatises of Government, introduced responsibility as a civic virtue. That notion of civic responsibility assumed an American characteristic in the writings of Alexander Hamilton and James Madison in the Federalist Papers (Lerner, 2001). Max Weber (1958) broadened the term to apply to all aspects of life when he connected the Protestant ethic of responsibility with the 'spirit of capitalism.' He argued that wealth was viewed as a sign of election by God for salvation. Being among the elect, successful burghers must act accordingly. To legitimize their status, they must be seen as exercising responsibility in many areas of public life-for example, by joining volunteer benevolent associations, serving on citizen committees, and supporting various charities (Davis, 2001). Considerable importance has been attached to an ethic of responsibility by scholars such as [H. Richard] Niebuhr (1963) and Jonsen (1968) within Christianity, Brueggemann (2001) and Vogel (2001) within the Jewish community, Cooper (1991, 1998, 2001) in public administration, and Moran (1996) in education. More recently, social science scholars (Auhagen and Bierhoff, 2001a, 2001c) have weighed in with research on the social phenomenon of responsibility as the human race faces complex challenges of the third millennium." (ibid., 48.)
} 
and not in imitation of anyone else's." 86 This authenticity and uniqueness is reflected in a specific leadership style. Leaders should use their power in ways that reflect their own character. In his discourse on authenticity, Starratt pointed out that leaders must be truthful to themselves, express their originality, and follow their convictions, beliefs, and values in their leadership practice using their unique qualities ${ }^{87}$ In other words, leadership must reflect the unique personality and gifts of the leader.

\section{Presence}

According to Starratt, the third characteristic of ethical leadership and the link between responsibility and authenticity is presence. ${ }^{88} \mathrm{~A}$ human being is defined by interaction and involvement with other humans. Leaders exist in a real world in society with people. If the leader is not present, he/she cannot affect others. Presence also brings a relational dimension to responsibility and authenticity, a medium through which responsibility and authenticity find expression.

In his analysis of ethical leadership, Starratt applied his observation primarily to educational leadership, although these principles can be applied to leadership at large. The virtue of taking responsibility, of being authentic, of being fully present, define a morality of the conduct and character of the ethical leader.

\footnotetext{
${ }^{86}$ Charles Taylor, The Ethics of Authenticity (Cambridge, MA: Harvard University Press, 1992), 29.

${ }^{87}$ Robert J. Starratt, Ethical Leadership, 65, 66.

88“"Humans are essentially relational beings (Taylor, 1991). We do not exist in a void, without people and society. We cannot define or express ourselves unless it is in relationship to others. ... Our existence is perpetually dialogical. My presence to you brings you inside of me, and projects me inside of you. I am still me, although the me that I am is involved with you. You are still other than me, although you also reflect me to myself. . . Being present takes place through the medium of language and also through our bodily expressions." (ibid., 85-86.)
} 
A morally appropriate use of power reflects the responsibility, authenticity, and presence of the ethical Christian leader. A Christian leader is not merely someone who makes decisions, organizes, gives orders, and shapes the policies of an institution. The Christian leader should be a model for those whom he/she leads, proof that the realm of beliefs works in the practice of everyday life. "Leaders must serve as models and mentors, not martinets." ${ }^{89}$ In the realm of Christian leadership, the leader is a representative of Christ and a model of how Christians imitate Christ.

Although all three components of ethical leadership are important, this study focuses special attention on responsibility. Abuses of power are often related to leaders fulfilling their responsibility in order to produce a certain result. That perception of "responsibility" results in actions that are not justified by the leader's position or authority. In business or politics, strong leaders with significant power might be very effective and desirable; however, in Christian leadership, leaders have a different responsibility based on their power being delegated by God. The issue of responsibility was mentioned briefly in the introduction in the discussion on abuses of power, and will be used in the analysis of leaders in the case study.

\section{Perspectives on Ethical Leadership}

Leadership theory involves many current perspectives on ethical leadership. That diversity reflects different ethical views, ideologies, and authorities accepted as the standard for principles, values, norms, and concepts defined. In the book Leadership, Northouse proposes three perspectives representing the most common ideas in the realm

\footnotetext{
${ }^{89} \mathrm{Al}$ Gini, My Job, My Self: Work and the Creation of the Modern Individual, 164.
} 
of ethical leadership. ${ }^{90}$ Such perspectives include those of Heifetz, Burns, and Greenleaf. $^{91}$

The Heifetz perspective posits that leaders must include the use of authority to help followers manage opposing values resulting from rapid changes in the work environment and culture. That perspective carries an ethical dimension because it directly affects the values of workers. ${ }^{92}$ A leader helps people to overcome hardships in their organizations and communities and uses authority to create a secure environment for their work. A leader is present for the workers to help them face conflicts and make changes despite the conflicts.

“Burns's theory of transformational leadership places a strong emphasis on followers' needs, values and morals." 93 Therefore, leaders should move followers to a higher level of moral responsibility, to transform their moral being and help them grow morally. "For Burns, it was the responsibility of the leader to help followers assess their own values and needs in order to raise them to a higher level of functioning, to the level that will stress values such as liberty, justice, and equality (Ciulla, 1998)."94

The third perspective, termed the servant leadership perspective, is of such great importance for the ethics of leadership that Northouse, in the latest edition of his book,

\footnotetext{
${ }^{90}$ Peter G. Northouse, Leadership: Theory and Practice, 4th. ed. 346.

${ }^{91}$ See: ibid., 347-349.

${ }^{92}$ Ibid., 347.

${ }^{93}$ Ibid., 348.

${ }^{94}$ Ibid.
} 
added an entire chapter dedicated to that perspective. ${ }^{95}$ Such a perspective also carries importance for this study because of the connection to the biblical concept of leadership and as a bridge between secular ethics and Christian ethics. While there is a trend in the Christian scholarship to equalize the secular model of Servant Leadership with the Christian leadership models, ${ }^{96}$ this study is perceiving them as two different models. Consequently, a depiction of the secular Servant leadership model as a separate model is necessary. The remainder of this chapter focuses on the servant leadership model.

\section{Servant Leadership}

Robert Greenleaf first introduced the servant leadership model in 1970 and since then, this concept has gained wide acceptance by many prominent and well-known writers on leadership. ${ }^{97}$ Greenleaf's main postulate of servant leadership, “The servant-

${ }^{95}$ See Peter G. Northouse, Leadership: Theory and Practice, 6 th. ed. (Thousand Oaks, CA: Sage Publications, 2013), 219-252.

${ }^{96}$ Scholarly work at Regent University is obvious example.

${ }^{97}$ See W. Bennis, "Become a Tomorrow Leader," in Focus on Leadership ServantLeadership for the Twenty-First Century, ed. Larry C. Spears and Michele Lawrence (New York: J. Wiley \& Sons, 2002); K. Blanchard and P. Hodges, The Servant Leader: Transforming Your Hearts, Heads, Hands, and Habits (Nashville, TN: Thomas Nelson, 2003); Stephen R. Covey, Principle-Centered Leadership; Max De Pree, Leading Without Power: Finding Hope in Serving Community (Holland, MI: Shepherd Foundation, 1997); P. M. Senge, "Afterword," in Servant Leadership: A Journey Into the Nature of Legitimate Power, ed. R. K. Greenleaf (New York: Paulist Press, 2002); Larry C. Spears and Michele Lawrence, Practicing Servant-Leadership: Succeeding Through Trust, Bravery, and Forgiveness, 1st ed. (San Francisco, CA: Jossey-Bass, 2004); Larry C. Spears, "Tracing the Past, Present, and Future of Servant-Leadership," in Focus on Leadership Servant-Leadership for the Twenty-First Century, ed. Larry C. Spears and Michele Lawrence (New York: J. Wiley \& Sons, 2002); M. Wheatley, "The Work of Servant Leader," in Focus on Leadership Servant-Leadership for the Twenty-First Century, ed. Larry C. Spears and Michele Lawrence (New York: J. Wiley \& Sons, 2002). 
leader is servant first," 98 is well known and based on the notion that a leader is in service to those he/she leads. Harold Waterman explained the particularity of this model by pointing that the servant leader focuses primarily on the needs and benefits of those he/she leads. By doing that it helps the followers to reach their full potential. ${ }^{99}$ While many attempts to express the essence of the servant leadership model have been made, they all share an emphasis on the moral character of a leader, and the need to put followers in the center of attention. ${ }^{100}$ Consequently, it can easily be concluded that servant leadership is a part of character-based ethics. Greenleaf suggested a test for detecting the servant leader: "The best test, and difficult to administer, is: do those being

\section{${ }^{98}$ Robert K. Greenleaf, Servant Leadership: A Journey Into the Nature of Legitimate Power and Greatness (New York: Paulist Press, 1991), 6.}

99"'Servant leadership differs from other models of leadership in that it focuses on leaders meeting the needs of followers, in that, if followers are treated as ends in themselves, rather than means to an end, they will reach their potential and so perform optimally." (Harold Waterman, "Principles of 'Servant Leadership' and How They Can Enhance Practice," 25.)

${ }^{100}$ For Northouse, "The central focus of the model is the seven behaviors of leaders that foster servant leadership: conceptualizing, emotional healing, putting followers first, helping followers grow and succeed, behaving ethically, empowering, and creating value for the community." (Peter G. Northouse, Leadership: Theory and Practice, 230.)

In Seven pillars of servant leadership James W. Sipe and Don M. Frick defined servant leadership: "A Servant-Leader is a person of character who puts people first. He or she is a skilled communicator, a compassionate collaborator who has foresight, is a systems thinker, and leads with moral authority." (James W. Sipe and Don M. Frick, Seven Pillars of Servant Leadership : Practicing the Wisdom of Leading by Serving (New York: Paulist Press, 2009), 20.)

Waterman pointed out character and foresight as the defining qualities of servant leadership. He suggested, based on Sipe and Frick's article, that character includes integrity and humility, in service of a higher purpose of generating and casting a vision. Although a leader can only appear as a servant leader for a time, sooner or later, his/her character reflected in decisions, behavior, and attitudes will reveal the real nature of the person's leadership. Who the leader is and how much he/she really wants to serve will determine the readiness of individuals to follow in the long term. (Harold Waterman, "Principles of 'Servant Leadership' and How They Can Enhance Practice," 26.) 
served grow as persons; do they become healthier, wiser, freer, more autonomous while being served?"101

Greenleaf admitted that the idea of servant leadership is paradoxical ${ }^{102}$ and counter-cultural. ${ }^{103}$ Servant leadership calls for a leader to be one who serves, or is to influence by serving. This is contrary to a common view that "leaders influence and servants follow." ${ }^{104}$ Servant leadership significantly changes the dynamic of power, as well as the type of authority. Thus, the paradox of servant leadership is - the one who leads others, in order to be a leader, has a position of honor, and makes decisions, has to serve others in the first place.

Although research on the effectiveness of servant leadership is at the early stage, some research shows that servant leadership increases team effectiveness. ${ }^{105}$ The greatest strength of servant leadership is that it moves the focus from power and authority to

${ }^{101}$ Robert K. Greenleaf, The Servant-Leader Within: A Transformative Path, ed. Hamilton Beazley, Julie Beggs, and Larry C. Spears (New York: Paulist Press, 2003), 42.

102، There may be a real contradiction in the servant as leader." (Robert K. Greenleaf, Servant Leadership: A Journey Into the Nature of Legitimate Power and Greatness, 5.)

${ }^{103}$ Joe Anderson depicted the counter-cultural nature of servant leadership: "The prevailing institutional culture says, 'watch out for number one,' whereas the servant-leader says, 'put others first.' The prevailing institutional culture says, 'it's survival of the fittest,' whereas the servant-leader says, 'we are all in this together.' The prevailing institutional culture says, 'never trust anyone,' whereas the servant-leader says, 'trust everyone unless, and until, they prove themselves untrustworthy." (Joe Anderson, "The Writings of Robert K. Greenleaf: An Interpretive Analysis and the Future of Servant Leadership" (paper presented at the Servant Leadership Research Roundtable, May 2008), 2.)

${ }^{104}$ Peter G. Northouse, Leadership: Theory and Practice, 219.

${ }^{105}$ See J. Hu and R.C. Linden, "Antecedents of Team potency and Team Effectiveness: An Examination of Goal and Process Clarity and Servant Leadership," Journal of Applied Psychology 96, no. 4 (2011). 
cooperation and mutual respect. Consequently, leadership is less prone to abuses, and those who are led have few problems with the authority of the leader.

One of the challenges of servant leadership is how to balance the coercive nature of leadership with the servant one, which seems to be submissive. For Greenleaf, the solution lies in the fact that "the great leader is seen as servant first, and that simple fact is the key to his greatness. . Leadership was bestowed upon a person who was by nature a servant." 106 Greenleaf additionally suggests that the corruptive nature of power in leadership can be controlled by changing the mindset of the leader from being a leader who has and exercises his power to a leader who is primarily in service to those whom he leads. What he did not explain thoroughly is how to change the mindset of leaders, and is the person who is not servant by nature excluded from leadership.

To fulfill the basic premise of servant leadership to put others first, servant leaders should have a "servant heart," care for the needs of others, and mentor and build up others, even at their own expense. Waterman tried to overcome the dichotomy of servant leadership by explaining that "Having a 'servant's heart' does not mean offering service at all times in all situations. It means bearing the idea of being a servant in mind, when decisions are made and action is taken." ${ }^{107}$ An unfortunate interpretation of his words could be that servanthood is something applied only when benefits the leader.

This is not the only weak aspect of servant leadership. In their article on servant leadership Paul Wong and Dean Davey listed six criticisms-weaknesses of the model:

\footnotetext{
${ }^{106}$ Robert K. Greenleaf, Servant Leadership: A Journey Into the Nature of Legitimate Power and Greatness, 2.

${ }^{107}$ Harold Waterman, "Principles of 'Servant Leadership' and How They Can Enhance Practice," 25.
} 
1. Servant Leadership (SL) is too idealistic and naive. In an individualistic consumer culture, many people will take advantage of the servant leaders' kindness as weakness (Johnson, 2001)

2. It is too unrealistic and impractical. It would not work in many situations such as military operations or prison systems (Bowie, 2000)

3. It is too restrictive, because we need all sorts of leadership qualities, such as intuition, risk taking and courage

4. It is too closely tied to Christian spirituality, because it is impossible for people to model after Christ's humility without being redeemed and transformed by the Holy Spirit

5. It is too hypocritical - too many claim to be servant leaders but behave more like dictators

6. It is too foreign to my leadership style - I simply can't function as a leader if I adopt the SL model ${ }^{108}$

Those criticisms relate to the paradoxical nature of servant leadership. The fourth one is related to the misunderstanding and mixing of servant leadership with Christian ideas on leadership. Greenleaf introduced his leadership model based on the ideas from the novel by Herman Hesse, Journey to the East. His model was a secular model coincidental with biblical ideas and values but being ignorant of the Scripture. Many Christian sociologists present the Greenleaf's servant leadership as a Christian model and ignore differences between that model and biblical servant motif and ideas. ${ }^{109}$ In spite of their differences, the shared idea of servanthood is an excellent starting point for the development of the Christian model.

\section{Summary}

Ethical leadership is a relatively recent part of leadership theory primarily concerned with applying ethics in leadership. There are three group of theories of leadership presented in this study: theories about the conduct of a leader, theories about

\footnotetext{
${ }^{108}$ Paul T. P. Wong and Dean Davey, "Best Practices in Servant Leadership" (paper presented at the Servant Leadership Research Roundtable, July 2007), 4.

${ }^{109}$ This will be further discussed in the section about the Christian servant leadership
} 
the character of a leader, and principle-based theories. According to the first theories, the conduct of the leader is evaluated by either the consequence of an action or by the moral obligation to the leader to do what is right. Therefore, the conduct of a leader is either teleological or deontological in nature. The second theories are concerned with the character of the leader, and they are the virtue-based theories. Although virtue ethics is concerned with the ultimate goal-happiness, and it seems teleological in nature, its emphasis is not on the goals, but on the means of achieving that goal-virtues. Accepted virtues will shape the character while they will lead to the goal of blessedness. The biggest contribution of these theories is its emphasis on the importance of character for leadership. The character of leader is of particular significance for spiritual leadership too. The third theories emphasize the importance of leadership being based on following the principles. Regardless of the lack of clearly defined universal principles, Covey suggested fairness, equity, justice, integrity, honesty and trust as the "true north" principles. For Christians "true north" principle would be following the teaching of Scripture and example of Jesus. While those theories are deontological in nature, they are based on principles-virtues. What differentiates the principle-centered theories from the character-centered theories is their emphasis. One is primarily concerned with the character while the other one emphasizes the principles.

The most desired leadership from the perspective of the principle-centered leadership would be leadership based on legitimate power. Abuses of power can be detected by assessing the conduct and character of a leader, and by determining if the leader used legitimate power and was faithful to the principles he proclaimed. 
By additionally asking the questions about the components of ethical leadershipresponsibility, authenticity, and presence-abuses of power can be analyzed better. Of all those components, the issues related to responsibility are the most significant for the study of power abuses. Many cases of abuse are the result of the incorrect understanding of responsibility.

From the three reviewed perspectives on ethical leadership, the most important for this study is Greenleaf's servant leadership perspective. The idea that "the servant leader is a servant first" relates well to the biblical ideas of servanthood. The greatest strength of that perspective is its focus on cooperation and mutual respect, what makes abuses of power less likely. This perspective shares many ideas with the ideal model of Christian leadership this study proposes in the next section. The pattern for analysis of abuses of power relates to a detection of characteristics opposite to the positive models of (Christian) servant leadership.

\section{The Christian Model of Leadership}

Christian ethics assumes the application of ethics from the Christian perspective. It begins with Bonhoeffer's fundamental question: "Who is Jesus Christ for us today?" and continues with the practical application of Christian principles to everyday life, to human behavior and actions. In his analysis of Bonhoeffer's ethics, Schweiker describes

Bonhoeffer's unique ethics:

Christian ethics, he insists, must take up and transform the knowledge of good and evil with respect to Jesus Christ. It must reconsider the meaning of our being human in terms of the true origin of good and evil that is the being and choice of God, the 
divine election manifest in Christ. . . Ethics is about how Christ takes form in human life. ${ }^{110}$

Placing Jesus in the center of Christian life suggests a need for standards of morality which will shape and determine the practice of all Christians, including their leaders. Before proposing the Christian model of leadership, this study will define standards on which this model will be built.

\section{Unique Standards of Christian Ethics}

The standards of Christian ethics endorse the authority of Christ and such values as love, goodness, humbleness, self-sacrifice, justice, and truthfulness. As Grenz emphasizes, for the biblical writers and Christian ethicists alike, the fundamental question is "What does God require from us?" and a concise answer to it: "He has told you, O man, what is good; and what the Lord requires of you? But to do justice, to love kindness, and to walk humbly with your God." To do what is required is to be just, kind (love mercy), ${ }^{112}$ and humble, following God's will.

In his exegetical analysis of words used in Micah 6:8, Christopher Wright emphasizes the ethical value and dimension of using justice and kindness (love) in the

\footnotetext{
${ }^{110}$ William Schweiker, Power, Value, and Conviction: Theological Ethics in the Postmodern Age, 148.

${ }^{111}$ Stanley J. Grenz, The Moral Quest: Foundations of Christian Ethics, 246.

112،"The Hebrew word hesed which is behind the NIV translation 'mercy,' is a most important word for explaining the nature of covenant and its spiritual obligations. The English Bible uses many different terms to translate this one Hebrew word, which is so full of meaning. These include favor, goodness, kindness, loving-kindness, merciful kindness, mercy, and kindly." (Jon Dybdahl, Hosea-Micah: A Call to Radical Reform, The Abundant Life Bible Amplifier (Boise, ID: Pacific Press 1996), 215-216.)
} 
verse mentioned. He explains that while the verses in Deut 10:12-13 summarize all of God's requirements as five requests: fear, walk, love, serve and obey, of which love is central, "Micah reduces it still further to three: to do justice, love mercy and walk humbly with God (Mic 6:8)." ${ }^{113}$ In addition to those three, a fourth can be derived from the same verse. The first statement proclaims that it is good to fulfill God's requirements. The virtues of goodness and obedience (to act in accordance with the requirements) can also be regarded as a part of Christian ethics. Hence, to do good, follow God's requirements, do justice, love mercy/kindness, and walk humbly can be regarded as the basis for an ethics of Christian leadership on which the suggested model is constructed.

\section{The Christian Servant Leadership Model}

The concept of servant leadership is a relatively new concept in leadership theory. It is accepted by leadership theory because it offers many advantages to corporate leadership that other coercive leadership models lack. Because of the specific nature of Christian leadership, the Christian servant leadership model this study proposes differs from the servant leadership model as described in the secular leadership theory.

Comparing and even equalizing the biblical servant motif with the servant leadership concept seems logical because the servant leadership perspective articulated by Greenleaf has obvious biblical similarities. It is no surprise that Corne Bekker in his comprehensive review of theoretical models of leadership suggested a great variety of scholarly work on the Christian leadership. Recognizing the lack of attempt at systematizing them in a coherent whole, he grouped them in, (a) studies of leadership approaches of biblical characters; (b) historical, sociological, and contextual descriptions;

${ }^{113}$ Christopher J. H. Wright, Old Testament Ethics for the People of God, 305. 
(c) studies of historical Christian figures; (d) ethical explorations; (e) cross-faith comparative analysis; (f) formational process descriptions; (g) comparisons with leadership and management theories; (h) exegetical studies; and (i) attempts at a prototheory. ${ }^{114}$ Then he pointed out that the current theories and approaches concur about four characteristics of Christian leadership: 1. mimetic; 2. concerned with a correct understanding of power; 3. follower-centered, and 4. Christological. ${ }^{115}$ The second and third characteristics correspond to the ideas of servant leadership, with the Christian view having a distinct understanding of power based on the biblical teachings. The first and fourth characteristics are particular to the Christian servant leadership model. This model, while being "servant", is also Christocentric and mimetic. Based on the teaching and person of Jesus (Christological) and following his example (mimetic), Christian servant

\footnotetext{
114“"The recent interests in Christian leadership, popular and scholarly, have been varied in scope and research methodology and have been characterized by (a) studies of leadership approaches of biblical characters (Manz, 1998; Piovanelli, 2005; Whittington et al., 2005; Wildavsky, 1984); (b) historical, sociological, and contextual descriptions (Barnes, 1978; Bekker, 2006; Goetting, 2006; Guenther \& Heidebrecht, 1999; Liftin, 1982; Nikkel, 1991; Papademetriou, 2003; Polomo, 1997; Sterk, 1998); (c) studies of historical Christian figures (Bekker, 2008b; Clarke, 1998; Karecki, 2008; Patrick, 2008; St. John, 1998); (d) ethical explorations (Karff, 1994; Kretzschmar, 2007; Wheeler, 1993; Willimon, 2002); (e) cross-faith comparative analysis (Freedman \& McClymond, 2001); (f) formational process descriptions (Engstrom, 1976; Faulhaber, 2008; Kretzschmar, 2002; Miller, 2005; Robinson, 2005; Thiessen, 2005); (g) comparisons with leadership and management theories (Gary, 2007; Heuser \& Klaus, 1998; Lamkin, 2005; Longbotham \& Gutierrez, 2007; Middleton, 2006; Prosser, 2007); (h) exegetical studies (Clarke, 1992; Faulhaber, 2007; Hierberts, 1976; Poon, 2006; Rogers, 2006; Still, 2004); and finally (i) attempts at a proto-theory (Ayers, 2006; Bekker, 2006; Koening, 1993; Niewold, 2007; Sanders, 1967; Stott, 2002)." (Corne J. Bekker, "Towards a Theoretical Model of Christian Leadership," Journal of Biblical Perspectives in Leadership 2, no. 2 (Summer 2009): 143.)

115 “. . the current theories and approaches agree that Christian leadership is (a) mimetic (Ayers, 2006; Bekker, 2006; Clark, 1992; Niewold, 2007; Whittington et al., 2005), (b) concerned with a correct understanding of power (Ayers; Bekker; Clark; Engstrom, 1976, Kretzschmar, 2002; Whittington et al.), (c) follower-centered (Ayers; Bekker; Clark; Kretzschmar; Whittington et al.), and ultimately (d) Christological (Ayers; Bekker; Clark, 1992; Engstrom; Kretzschmar; Niewold; Whittington et al.)." (ibid., 148.)
} 
leadership requires the authority to be expressed and practiced through service. Jesus' use of powerless power is the ideal Christian leaders have to imitate. He, who had power and authority, submitted his intrinsic authority and humbled himself by taking upon himself human nature. He who possessed the right, power, and authority to give orders, served instead and even sacrificed himself. He submitted his will to his Father despite his equality with his Father.

The servanthood of these two models, Christian and secular, is different. According to the secular model, a leader is a servant of the people because he leads them through service. However, the Christian leader should primarily be the servant of the Lord, submitting to his authority and following his guidance. Thereby, serving others is merely an extension of service to God. While the secular model proposes servanthood in heart, Christian model requires servanthood as the essence of leadership. ${ }^{116}$ The spiritual leader should fulfill various needs of those he leads by being a servant of the Lord and servant of people.

The servant motif in the Scripture includes many different ideas and pictures. In the Old Testament narrative, according to Klyne Snodgrass, ${ }^{117}$ it includes notions of being slaves in Egypt or of honoring the leadership of leaders such as Moses and David, servants of the Lord. Israel as a nation is also a servant of the Lord. When the title "servant" was explicitly given to the person, it was not a sign of weakness, but rather a

\footnotetext{
${ }^{116}$ John Eric Adair notices, "The most distinctive aspect of Jesus' teaching on leadership is his emphasis that a leader is essentially a servant." (John Eric Adair, The Leadership of Jesus and Its Legacy Today (Cleveland, OH: Pilgrim Press, 2002), 138.)

${ }^{117}$ Klyne R. Snodgrass, "You Slaves on Account of Jesus: Servant Leadership in the New Testament," in Servant Leadership: Authority and governance in the Evangelical Free Church, ed. James R. Hawkinson and Robert K. Johnston (Chicago, IL: Covenant Publications, 1993), 8.
} 
label for aggressively facing injustice. The narrative describes the functions of "the servant" as either the whole nation or individuals, with the tasks of obedience, bringing justice, witnessing, and suffering.

Based on the teachings and example of Jesus, the NT model is the fulfillment of the Old Testament model in practice. Old Testament suffering language is applied to Jesus' service in the NT. The NT servant motif is further enhanced by Jesus' narrative on leadership.

Jesus used two Greek words to describe his concept of servanthood: doulos (servant or slave) and diakonos (servant at the table). Adair describes a difference between those two words. ${ }^{118} \mathrm{He}$ indicates that "doulos" is used to emphasize the task, accountability, submission to authority, or obedience, whereas "diakonos" is used more frequently when emphasizing love, humility, and service to others. According to Strong, diakonos is one who serves a master, attendant, minister, ruler or church by executing the orders, caring for the poor and distributing money and goods, and serving food and drink. ${ }^{119}$ These two words doulos and diakonos cover various tasks related to service and leadership. They are used not only for the leaders of the church but also for all believers. ${ }^{120}$

Without making a distinction between secular and Christian servant leadership, Kathleen Patterson in her article on a theoretical model of servant leadership proposed a

${ }^{118}$ John Eric Adair, The Leadership of Jesus and Its Legacy Today, 138.

${ }^{119}$ Strong's data for "servant" <1249> in Bibleworks 9 Software for Biblical Exegesis \& Research (Norfolk, VA: Bibleworks, 2011).

${ }^{120}$ See details about the use and meanings of NT words related to servanthood: (Klyne R. Snodgrass, "You Slaves on Account of Jesus: Servant Leadership in the New Testament," in Servant Leadership: Authority and governance in the Evangelical Free Church, 10.) 
pattern of seven virtues on which servant leadership is based: agapao love, humility, altruism, vision, trust, empowerment, and service. The first virtuous construct she proposed is specific for the Christian servant leadership model. Christian model, shaped by the biblical perspective, is based on love. Martin Luther King Jr. understood this concept when he said: "Power without love is reckless and abusive, and love without power is sentimental and anemic. Power at its best is love implementing the demands of justice."121 Therefore, the Christian values of justice, goodness, mercy, obedience, and humility must be observed through the prism of selfless love. The Christian leader must control and override the initial impulse to rule over and control others by serving those he leads with genuine love.

Jack Niewold, in his essay "Beyond Servant Leadership", challenged the noncritical and pragmatic approach and acceptance of the model of servant leadership by contemporary Christianity. ${ }^{122} \mathrm{He}$ indicated that servant leadership in its secular form lacked certain crucial elements of biblical Christology. An emphasis on Jesus’ servanthood overlooks his divine origin and intrinsic power. As H. Richard Niebuhr noticed, Jesus “... showed a confidence that had no trace of self-abnegation. Whatever may be true of his Messianic self-consciousness, he spoke with authority and acted with confidence of power."123

${ }^{121}$ As quoted from Daniel L. Migliore, The Power of God and the gods of Power, 72-73.

${ }^{122}$ See Jack Niewold, "Beyond Servant Leadership," Journal of Biblical Perspectives in Leadership 1, no. 2 (2007): 119-134.

${ }^{123}$ H. Richard Niebuhr, Christ and Culture (New York: Harper Torchbooks, 1975), 26. 
The complexity of Jesus' existence on this earth is a challenge for a simplified servant-leadership view. Jesus was not merely a servant first. Niewold noticed that Jesus fits into both kenotic and pleromatic views. ${ }^{124} \mathrm{He}$ was both a servant and a leader. He was simultaneously human and divine, submissive and coercive.

Niewold based his critique on the fact that servant leadership challenges many concepts of Christianity. He explains that in popular evangelicalism "servant leadership is characterized by inward-directedness and Pelagianism." ${ }^{125} \mathrm{He}$ explains that inwarddirectedness emphasizes the internal spiritual and mental processes as the means of eternal change, whereas Pelagianism is the result of excluding the transforming power of Jesus as the means of change.

While accepting a servant motif as the biblical model for leadership Niewold considered it insufficient to present the biblical concept of leadership adequately. Therefore, he proposed the concept of martyria as a necessary addition to the biblical model of leadership. ${ }^{126} \mathrm{He}$ explained that "the term 'martyria' and its cognate martys denote the act of Christian public proclamation and witness." ${ }^{127}$ Based on the example of Jesus, testimonies of the biblical writers, and practice of the early church Niewold

\footnotetext{
${ }^{124}$ See Jack Niewold, "Beyond Servant Leadership," 121. Kenosis - the "self-emptying" of one's own will and becoming entirely receptive to God's divine will; Pleroma-a concept of representing the fullness of the Divine Being.

${ }^{125}$ Ibid., 126.

126“I suggest that we adopt and build upon the biblical concept of martyria, which can be rendered, loosely, as 'witness' or 'testimony."” (ibid.)

${ }^{127}$ Ibid., 127.
} 
observed the wittness as the very heart of leadership. ${ }^{128}$ The concept of martyria, in addition to witnessing by proclamation, includes a mimetic element of witnessing by living the gospel and following Jesus' example.

That concept is not in the conflict with the servant element of Christian leadership. For him, “martyriological leadership will doubtless encompass much servitude and will not exist apart from it, but it will not be defined by it." ${ }^{\prime 29}$ Thus, Christian leadership might include a servant component, but goes beyond the servant element because, by limiting Christian leadership to the servantship only, we reduce the gospel to ethical considerations. Servanthood has a rightful biblical place, and that place is in the context of Christian proclamation. Niewold stated, "it is my intent to restore servanthood to the position as adjunct to the calling of witness, without servanthood usurping the place of witness, or substituting for it, as seems to have happened since the 1970s. ${ }^{.130}$

Niewold has raised some important and valid points. The servant motif is essential for the biblical concept of leadership, but Christian servant leadership is not limited to servanthood alone. According to Jesus, a Christian leader who strives to be great must begin leadership as one who serves people while is a servant in the service of God. But at the same time, such leader might use (or give up if necessary) the appropriate kind of power to advance God's kingdom and to be the witness of an all-powerful God.

\footnotetext{
${ }^{128}$ Ibid., 128.

${ }^{129}$ Ibid., 133.

${ }^{130}$ Ibid.
} 
Jesus denounced dominant and coercive power among his followers: "But you, do not be called 'Rabbi;' for One is your Teacher, the Christ, and you are all brethren. Do not call anyone on earth your father; for One is your Father, He who is in heaven. And do not be called teachers; for One is your Teacher, the Christ. But he who is greatest among you shall be your servant. And whoever exalts himself will be humbled, and he who humbles himself will be exalted" (Matt 23:8-12) Consequently, Christians are brothers and sisters without a ruler among them. They are all servants of the Lord and priests in his service. Such an approach is based on equality between members, and the notion of the priesthood of all believers. ${ }^{131}$ No distinction exists between priests and laity, leaders and followers. Thus, humility is necessary for the appropriate expression of power in the context of Christian leadership. Humility is not possible without surrendering one's ego. Christ proved his humility by accepting human nature and by his willingness to die for humans; Christians should imitate his example. All three applications of Jesus' view of leadership — equality, humility, and rejection of ego—do not seem necessary for successful secular leadership. However, for Christian servant leaders, they are the requirements.

The Christian servant leadership model is counter-cultural. Standard views on leadership, which call for dominance, coercion, titles, and public recognition are challenged with Jesus' call for unselfishness, humility, equality, and self-denial. At first glance, the leadership including qualities Jesus required, would look passive, weak, and

${ }^{131}$ This notion is derived from the apostle Peter's writings in which he names all believers as a holy and royal priesthood, de facto placing responsibility of the priesthood on every member (1 Pet 2:5, 9). This concept is part of the Protestant heritage based on the teaching of Martin Luther expressed in To the Christian Nobility of the German Nation and On the Babylonian Captivity of the Church. 
lacking in authority. Nonetheless, that is not the case. Norma Cook Everist and Craig L. Nessan stated, "Leaders themselves seem to err either by abusing power or by abdicating authority... Servant-leaders understand power and are not afraid to lead in making things happen, empowering others also to do the work of the Spirit." ${ }^{\prime 32}$ In spite of its servanthood, the Christian servant leadership is supposed to be decisive and efficient.

\section{Summary}

Christian servant leadership shares many significant elements with the servant leadership perspective. Nevertheless, its uniqueness is in a double servanthood, Christocentricity, and mimeticity. It founds its expression in love which endorses Christian virtues of justice, goodness, mercy, and obedience. As such it is effective witness and testimony of God's kingdom.

While the two nouns servant and leader describe two seemingly opposed functions, their combination in the unique phrase requires some resolution. For Christian servant leaders, a solution for being a servant and leader at the same time lies in biblical perspective on the power of God and power of humans. The ultimate leader for Christians is Jesus Christ, God himself. The Christian leader is a servant under God's leadership. Jesus has addressed the corruptive nature of power by indicating that Christian greatness is not in a position, but rather, in service. Thus, the authority of Christian leaders lies in their service to God. This position of authority is also affected by the leader's character, which should reflect the leader, Jesus Christ, and not a leader's position of power.

\footnotetext{
${ }^{132}$ Norma Cook Everist and Craig L. Nessan, Transforming Leadership: New Vision for a Church in Mission (Minneapolis: Fortress Press, 2008), 65. 69.
} 
The Christian servant leadership model allows the use of all types of power, "power over", "power within" and "power with," as long as they are submitted to the authority of the Lord. Jesus used power when necessary but never for a selfish reason, or for personal advantage and benefit. The Christian servant leadership model also supports the equality of all members based on the concept of the priesthood of all believers, encourages teamwork, diminishes a need for personal gratitude for achievements, takes care of relationships, avoids the use of coercive power and the corruptive nature of power and status, and endorses leading by example. In the following section, we are proposing the pattern for the analysis of abuses of power based on the rejection of the Christian servant leadership model.

\section{The Pattern for Analysis of Abuses of Power}

Applying the Christian servant leadership model in practice could prevent abuses of power. The noticeable existence of abuses of power shows that some leaders do not implement that model. To detect and analyze those abuses there is a need for clarifying two approaches/paradigms of the use of power. First one focuses on the successful use of power, and the second one centers on the good and right use of power. Those paradigms together with the proposed model will serve as the basis of the pattern for exposing and examining abuses of power.

\section{Two Paradigms of the Use of Power}

The morality of power is determined by our actions - how we use power. Theology and ethics alike recognize that power can be used for good or bad. Instead of discussing power in terms of good and bad, the use of power can be evaluated as the ethical use of power versus the use of power for success. Those two paradigms of the use 
of power are discerned by their ultimate purpose of the actions: either to do what is good and right or to be successful.

The first paradigm of the use of power, labeled as the ethical use, in its Christian version is related to the biblical concept of power and based on principles of love, justice, goodness, and rightness. Consequently, this use of power abides by laws and rules. It is based on given or deserved authority, though it is intrinsically benevolent. This power is founded on virtue and it is not supposed to be deceptive. Regardless of its greatness and power, the limitation and restriction of this power are inherent in the principles it follows.

Paradoxically, while that paradigm of power is bound by laws, endorses the concept of love and sacrifice, and appears to be limited, ultimately provides freedom. The boundaries of that paradigm balance relationships and support compassion and cooperation. Although such a paradigm of power is based on virtue, it has a teleological dimension in an attempt to do what is good and prosperous. Excellent examples of the application of that concept of power are the creation of the world, or re-creation achieved through God's plan of salvation. The prophet Jeremiah described God's act of creation: "He has made the earth by His power, He has established the world by His wisdom, and has stretched out the heavens at His discretion" (Jer 10:12). The use of power according to that concept is meaningful. It does not attempt to sustain itself, but to produce a creative, positive result. According to Jesus, the purpose of that power is to be used for the good of others - to serve them: "And He said to them, 'The kings of the Gentiles exercise lordship over them, and those who exercise authority over them are called 'benefactors.' But not so among you; on the contrary, he who is greatest among you, let him be as the younger, and he who governs as he who serves. For who is greater, he who 
sits at the table, or he who serves? Is it not he who sits at the table? Yet I am among you as the One who serves." (Luke 22:25-27).

The second paradigm of the use of power cares about success, not a virtue. This power uses any method available and rejects any restriction preventing success. It is selfserving and pragmatic. The biblical example of this concept is the application of power by the forces of evil. Abuses of power can be traced to this paradigm. This is the reason why an understanding of that paradigm is essential for studying of power abuses.

Niccolo Machiavelli (1469-1527) first defined the second paradigm of power in his well-known work, The Prince, expressing his view on political power and the methods needed for power to be sustained. For him, "the prince" was a synonym for the successful leader, and from his study of history and political practice he tried to derive principles that the leader must observe in order to be successful.

His views include several axioms such as:

It is far safer to be feared than loved. ${ }^{133}$

Hence it comes that all armed Prophets have been victorious, and all unarmed Prophets have been destroyed. ${ }^{134}$

It is necessary, therefore, for a prince who desires to maintain his position, to use or not to use his goodness as occasion may require. ${ }^{135}$

Therefore, a prudent ruler ought not to keep faith when by so doing it would be against his interest, and when the reasons which made him bind himself no longer exist. If men were all good, this precept would not be a good one; but as they are bad, and would not observe their faith with you, so you are not bound to keep faith with them. ${ }^{136}$

${ }^{133}$ Niccolò Machiavelli, The Prince, trans. Harvey C. Mansfield, Jr. (Chicago, IL: University of Chicago Press, 1985), 111.

${ }^{134}$ Ibid., 33, 34.

${ }^{135}$ Ibid., 102.

${ }^{136}$ Niccolo Machiavelli, The Prince and Other Writings, trans. Luigi Ricci and J. Scott Berley (Digireads.com Publishing, 2012), 34. 
According to Machiavelli, a leader must be concerned about morality only if it is in his own interest. Otherwise, he must do what is in his best interest. This is because he finds that all people are bad, and that by keeping his integrity and promises the leader puts himself at a disadvantage. Therefore, morality is secondary to the leader's interest; it is relative and depends on how useful it is to achieve the first goal, which is to sustain power.

A more drastic example of the immorality of Machiavelli's views is his appeal to leaders to learn how not to be good.

Therefore, it is necessary for a prince, who wishes to maintain himself, to learn how not to be good, and to use it and not use it according to the necessity of the case. Leaving on one side then those things which concern only an imaginary prince, and speaking of those that are real, I state that all men, when spoken of, and especially princes, who are placed at a greater height, are noted for some of those qualities which bring them either praise or blame. ${ }^{137}$

Machiavelli suggested that, a leader who is concerned about morality and is simultaneously successful does not exist because armed prophets succeed and unarmed prophets fail. He asserts that Jesus failed, and would agree with another proponent of this paradigm, Friedrich Nietzsche ${ }^{138}$ that by killing his brother, Cain was a winner fighting for his position. Machiavelli finds justification for his views in his observance of reality, which shows that in order for a leader to be successful he must be pragmatic and use any

${ }^{137}$ Ibid., 30.

${ }^{138}$ According to Nietzsche "will to power" is the main force and motivation behind everything - an explanation of all behavior. There is no universal morality as such and thus "will to power" cannot be judged being good or bad. (Friedrich Nietzsche, Thus Spoke Zarathustra: A Book for All and None, trans. Walter Kaufmann (New York: Penguin Books, 1980); Friedrich Nietzsche, Beyond Good and Evil: Prelude to a Philosophy of the Future, trans. R. J. Hollingdale (New York: Penguin Books, 1990).) 
method that works, instead of imaginary ideals. That ideal, according to Machiavelli, does not produce desired results and does not work in practice.

Machiavelli also endorsed the visionary capabilities of a leader, but in this case, a good leader is one who is better at predicting possible dangers coming from his enemies and preventing them while he has time. Visionary elements again point to the goal of retaining power rather than causing improvements and better results. He was likely the one to first describe preemptive strikes against foes. ${ }^{139}$

Although Machiavelli did not intend to discuss the morality of leaders in his work, his amoral approach has raised many moral questions. Even more fascinating is the fact that most politicians worldwide follow the ideas expressed by Machiavelli. They may not pay attention to the morality of their actions (except if it is to their own advantage), but rather, they take a pragmatic stand and make decisions that will produce the greatest advantage for them or their supporters. The desire for reelection often dictates the notion of pleasing voters or appearing to them as the best choice, rather than maintaining integrity and standing for what one believes is right and best. That is why the public perceives most politicians as people who will do whatever it takes to retain their

139،"For the Romans did in this case what all wise princes should do, who look not only at present dangers but also at future ones and diligently guard against them; for being foreseen they can easily be remedied, but if one waits till they are at hand, the medicine is no longer in time as the malady has become incurable; it happens with this as with those hectic fevers spoken of by doctors, which at their beginning are easy to cure but difficult to recognize, but in the course of time when they have not at first been recognized and treated, become easy to recognize and difficult to cure. Thus it happens in matters of state; for knowing afar off (which it is only given to a prudent man to do) the evils that are brewing, they are easily cured. But when, for want of such knowledge, they are allowed to grow so that everyone can recognize them, there is no longer any remedy to be found. However, the Romans, observing these disorders while yet remote, were always able to find a remedy, and never allowed them to proceed in order to avoid a war; for they knew that war was not to be avoided, and could be deferred only to the advantage of the other side." (Niccolo Machiavelli, The Prince and Other Writings, Digireads.com Publishing, 10.) 
position of political power. In his book The 48 Laws of Power,${ }^{140}$ Robert Greene followed Machiavellian views and suggested forty-eight practical suggestions for how to gain and sustain power. His emphasis was not on morality, but on the practicality of those methods. He was not trying to teach people how to be moral, but how to succeed in their quest for power. Green proposed some of the following laws: conceal your intention; court attention at all cost; get others to do the work for you, but always take the credit; learn to keep people dependent on you; use selective honesty and generosity to disarm your victim; when asking for help, appeal to people's self-interest; pose as a friend, work as a spy; do not commit to anyone; re-create yourself; control opinions; get others to play with cards you deal; think as you like, but behave like others. Surprisingly, many of those ideas are applied by Christian leaders, despite the fact that the morality of those ideas is strongly opposed to the principles of biblical morality.

The greatest problem with this paradigm of power is that it is self-centered, often corrupted, and ultimately, self-destructive. Although it appears to be attractive, free of restrictive rules and laws, nearly limitless, and can employ any method to accomplish one's goals, in the end, it does not create morally good results. The goals of that power are not to do what is good or what is right, but rather to be in charge, to have power, to fulfill one's wishes, and to sustain a position of power.

Those two depicted paradigms and their variations are in conflict, and every leader chooses, although often subconsciously, which one to apply in practice. The first paradigm with the discourse on ethical leadership is a foundation for the idealistic model 1998).

${ }^{140}$ Robert Greene and Joost Elffers, The 48 Laws of Power (New York: Viking Adult, 
of Christian leadership proposed in this chapter. However, abuses of power will be detected and analyzed in the fourth chapter on the basis of the second paradigm and in the contrast to the proposed model. The ethical analysis of the abuses of power of the two leaders involved in the case of kingly power will use the pattern of questions described in the next section.

\section{The Basis of the Pattern}

This study is concerned only with one aspect of Christian leadership - abuses of power. In the process of creating the theoretical framework for the analysis of abuses, it discussed the biblical background for the ethics of power and scholarly studies on the ethics of leadership. Then, it proposed the exemplary idealistic model of Christian leadership with its positive paradigm of power and is concerned with what is right for a leader to do. However, that model is descriptive, and so far, it has not suggested an ethical code of behavior.

Cook and Nessan in Transforming Leadership pointed out that many respective types of leadership prescribed ethical codes of behavior, but so far there is no unified ethical code proposed for Christian leadership. ${ }^{141}$ One possible reason could be a diversity of Christian beliefs and practices. In her attempt to bridge that gap, Karen Lebacqz articulated nine prima facie duties as guidance for ethical practice based on the work of W. D. Ross. She divided those duties into subgroups: (A) duties based on prior acts of my own - (1) making reparation for wrongs done, and (2) keeping promises; (B) duties based on the prior act of another - (3) duties of gratitude; (C) general duties - (4)

\footnotetext{
${ }^{141}$ Norma Cook Everist and Craig L. Nessan, Transforming Leadership: New Vision for a Church in Mission, 134.
} 
Doing good and (5) avoiding evil, (6) the duty of justice or equitable distribution of goods and evils, (7) a duty of self-improvement (in virtue and intelligence), (8) respect for the liberty and self-determination of the other (sometimes called the duty of autonomy, sometimes the principle of respect for persons), and (9) truth telling (honesty). ${ }^{142}$ Accordingly, an act can be considered morally right as long as it fulfills those duties.

In another attempt, Richard M. Gula proposed a code of ethics for pastoral ministry which can be applied to all Christian leadership. This code includes the following categories: (A) ideal characteristics of pastoral ministers (holiness, love, trustworthiness, altruism, and prudence), (B) professional obligations (theological competence, service of people's need for salvation, commitment to the other's best interest, care of ourselves, and use of power), (C) an appropriate sexual conduct, and (D) confidentiality. ${ }^{143}$ Consequently, Christian leaders have to implement and nurture that code in their leadership practice.

From the biblical and ethical principles elaborated in this study the proposed code of ethics for Christian leaders would be: 1. Christian leaders are servants of God; submissive to God's authority; 2. Christian leaders lead by serving people using their delegated power appropriately; 3. Christian leaders follow Christ's leadership and imitate his example; 4. Christian leaders act out of love; 5. Conduct and character of Christian leaders reflect their Christian values; 6. Christian leaders follow Christian principles of 1985), 25.

${ }^{142}$ Karen Lebacqz, Professional Ethics: Power and Paradox (Nashville: Abingdon Press,

${ }^{143}$ Richard M. Gula, Ethics in Pastoral Ministry (New York: Paulist Press, 1996), 142152. 
justice, goodness, mercy, obedience, and humility; 7. Christian leaders are responsible, authentic, and present. These seven codes of ethics practically and appropriately apply the principles of Christian servant leadership.

Abuses of power are based on breaking these suggested duties and codes, and they are the result of a negative paradigm which is concerned with the success, position and preservation of power and authority rather than with the morality of leadership. The theoretical framework is incomplete without a pattern to discern legitimate use of power from its abuses. Thereby, this chapter finishes with a set of questions-the pattern for detecting abuses of power and their analysis.

\section{The Pattern}

Based on what we have seen so far, an ethical analysis of power will try to locate the following abuses of power based on biblical background, the ethics of using power, the proposed model and negative paradigm of power: abuses related to misuse of authority, abuses related to mistreatment of subordinates, abuses related to preservation of power rather than to lead, abuses related to misconduct of the leader, abuses related to corrupted character traits, abuses related to ignoring the principles, and abuses related to misplaced responsibility, authenticity and presence.

The pattern for analysis includes a set of questions that this study will use to identify particular abuses:

1. Abuses related to misuse of authority: Did the leaders overstep or undermine their authority? Did they put themselves above the rules or laws or considered themselves the ultimate judge of what is right or wrong? Were they autocratic instead of being the servant of the Lord and serving people? 
2. Abuses related to mistreatment of subordinates: Did the leaders disrespect their subordinates and treat them improperly? Did they use coercive methods such as brutal force, inappropriate persuasion, or threatening others?

3. Abuses related to preservation of power rather than to lead: Did the leaders share power and position only with those whom they could control? Did they try to control others and the situations with rumors, gossiping, and dishonesty?

4. Abuses related to misconduct of the leader: Was the leaders' conduct inappropriate? Did the leaders apply selective honesty and generosity?

5. Abuses related to corrupted character traits: Did the leaders have traits of character which negatively affected their leadership? Did they take personal advantages of their position? Did they present themselves as better than others, and try to diminish the achievements of others?

6. Abuses related to ignoring Christian principles: Were they disrespectful to the principles? Did they disregard procedures? Did they ignore decisions and counsels of the boards?

7. Abuses related to misplaced responsibility, authenticity and presence: Were the leaders irresponsible? Did they show a lack of integrity? How did their responsibility affect their leadership?

These seven types of power abuses will be analyzed and evaluated according to the proposed model of Christian servant leadership. Some of these abuses are subtle and hard to detect. Even when one assumes their presence, there is often no way of proving them. Nevertheless, there are documents describing the conduct, character, and implied principles of the two leaders, which reveal some abuses of power in their leadership. 
These two leaders were chosen based on the fact that both of them were accused of overstepping their authority and behaving like kings. The fourth chapter will seek to answer questions from the proposed pattern (grid) to analyze their abuses of power. 


\section{CHAPTER 3}

\section{THE ISSUE OF KINGLY POWER IN THE}

\section{ADVENTIST CHURCH}

This chapter provides the historical and theological context of the kingly power struggle in the early Adventist church. It is divided into three sections. The first section provides an essential historical background and context. The second one discusses the Seventh-day Adventist doctrine of the church determining the theological context of the struggle. The third one presents the practical measures taken by the church to address or prevent abuses of power.

\section{The Kingly Power Controversy}

\section{Historical Context}

The issue called kingly power was the result of the many processes affecting the Advent movement during the early history of the church. One of the most visible was a rapid growth in membership. In 1847, there were about one hundred Sabbatarian Adventists. This small group grew and in 1863, when the Seventh-day Adventist Church was organized, there were 3,500 members. Church membership multiplied by more than twenty times between 1863 and 1901, and in 1901 it surpassed 78,000. George Knight pointed out that "between 1888 and 1900 the membership increased by 290 percent, and 
the church entered some 38 new nations." ${ }^{1}$ From the initial six local conferences the church organization grew to fifty-seven conferences and organized forty-one missions all over the world. ${ }^{2}$ There were seven auxiliary organizations established to care for various areas of the church's programs. ${ }^{3}$ This rapid growth affected all of the church's organizations and institutions.

The growth of the church during the 1890s had, according to Barry Oliver, at least four dimensions:

(1) It was numerical — new members were attracted to the church, particularly in the mission fields. (2) It was geographical - the church commenced working in at least one new overseas country each year, and in most years, three or four new countries. (3) It was organizational - three new auxiliary organizations were established, and those that had existed at the beginning of the period were themselves spawning auxiliary organizations and becoming more complex. (4) It was institutional-no period in the history of the Seventh-day Adventist Church has ever seen a more spectacular rate of institutional expansion than the 1890s. ${ }^{4}$

At this time, the church faced other external and internal pressures. Movements for the enforcement of Sunday laws and attacks on religious liberty came from the outside. In the aftermath of the Civil War, the National Reform Association pressed for the legalization of Sunday observance. During the last quarter of the nineteenth-century

${ }^{1}$ George Knight, Organizing to Beat the Devil: The Development of Adventist Church Structure (Hagerstown, MD: Review and Herald Pub. Association, 2001), 103.

${ }^{2}$ See: Richard Schwarz and Floyd Greenleaf, Light Bearers: A History of the Seventh-day Adventist Church, 241.

${ }^{3}$ George Knight, Organizing to Beat the Devil: The Development of Adventist Church Structure, 76. Knight lists "The General Tract and Missionary Society (1874), the Seventh-day Adventist Educational Society (1874), the General Sabbath School Association (1878), the Health and Temperance Association (1879, known as the Medical Missionary and Benevolent Association after 1893), the General Conference Association (1887), the National Religious Liberty Association (1889), and the Foreign Mission Board (1889).”

${ }^{4}$ Barry David Oliver, SDA Organizational Structure: Past, Present and Future, vol. XV, Doctoral Dissertation Series (Berrien Springs, MI: Andrews University Press, 1989), 129. 
as the result of that movement, many Seventh-day Adventists experienced persecution. According to Schwarz and Greenleaf, Adventists paid more than \$2200 in fines and they served over 1400 days in confinement and more than 450 in chain gangs. ${ }^{5}$ In 1889 the church organized the National Religious Liberty Association with A. T. Jones serving on the association executive and editorial committees. This organization supported separation of church and state in America and fought for religious freedom. Schwartz and Greenleaf speculate that because of the influence of J. H. Kellogg and the effort of the Religious Liberty Association (with the very significant work of A. T. Jones), both the arrests of Adventists and the Sunday-law campaign basically stopped by the beginning of the twentieth century. ${ }^{6}$

Internally, the church was struggling with the development of Adventist theology. The church was affected, together with many other denominations, by the Holiness movement. ${ }^{7}$ The emphasis of the movement was on both the perfect holiness and the work of Holy Spirit in the life of the believers. The most visible proponents of the Adventist holiness movement were A. T. Jones and A. F. Ballenger. While A. F. Ballenger, on behalf of the GC, worked on the spiritual revival in camp meetings and churches, as the editor of the Review and Herald, A. T. Jones was sharing the ideas of the movement among Adventists. In his editorial of November 22, 1898, he called for the

${ }^{5}$ Richard Schwarz and Floyd Greenleaf, Light Bearers: A History of the Seventh-day Adventist Church, 243.

${ }^{6}$ Ibid., 245.

${ }^{7}$ See: George R. Knight, A. T. Jones: Point Man on Adventism's Charismatic Frontier (Hagerstown, MD: Review and Herald Publishing Association, 2011), 192-196. 
"perfect holiness" of God's people. ${ }^{8}$ But he rejected Holy Flesh movement based on its stand on the sinfulness of Christ's human nature.

The extreme ideas of the Adventist Holiness movement resulted in Indiana in Adventist Pentecostalism (the Holy Flesh movement). Some of those ideas later gave rise to the issues of pantheism in the church. That epoch of the church's history witnessed many other extreme ideas among Seventh-day Adventists labeled as "new light." Such ideas were: the teachings that sacredness of life forbids the killing of insects, rodents or snakes; the teachings that God requires the perfection from the members and that people with gray hair and any physical deformation cannot receive the seal of God; that one cannot be completely healed if he/she is not a part of 144000; or the teachings that prayer for the sick requires stopping the use of medicine as proof of the acceptance of God' gift of healing. ${ }^{9}$ All of these factors created tensions among church leaders with their different opinions on these topics.

The church organization also faced serious financial issues. According to Schwarz and Greenleaf, church finances were affected by the depression of 1893, by the manner in which the church monies were used, and by dissatisfaction of members with use of money. ${ }^{10}$ The indebtedness was increased by expansion of the church institutions in

\footnotetext{
${ }^{8}$ Alonzo T. Jones, "Saving Health," The Review and Herald vol. 75, no. 47 (November 22, 1898): 752.

${ }^{9}$ See: George R. Knight, A. T. Jones: Point Man on Adventism's Charismatic Frontier; Richard Schwarz and Floyd Greenleaf, Light Bearers: A History of the Seventh-day Adventist Church.

${ }^{10}$ While the country was in a depression, the GC payroll tripled between 1892 and 1895. Church was borrowing many from members who were trusting church more than banks in which they lost money. Depreciation in the value of the property and lost it caused made very hard to return borrowed money. At the same time, money was unequally distributed. Same conferences
} 
Battle Creek. The lack of resources ignited a struggle for and over resources involving independent institutions and their leadership. It seems that leaders did not abuse power (or get involved in the conflicts) because of their personal interest but rather to help and advance the institutions in which they were in charge. ${ }^{11}$

The inevitable result of all these issues was both a struggle over control of the church as well as tension among the church leadership regarding the best solutions and methods for solving problems. The church faced the questions of philosophy of leadership and organization of the church. The resulting conflict between two branches of church missionary work - the ministerial and medical - is therefore the issue of the highest importance to this study. For it was in this environment that the issue of kingly power emerged. ${ }^{12}$

\section{Emergence of the Issue of Kingly Power}

The expansion of the church resulted in ambiguity about the most suitable type of leadership for the organization. Leaders often took extreme stances. The GC in 1873

had a surplus, and some were severely struggling. There was no official way of distributing surpluses to needy areas until 1905. Sabbath school offering declined. Experiment with additional offerings (the first day offering and the Christmas offering) didn't bring wanted results. There was no budgeting at that time. By 1896 the treasury of the GC was empty, and the church suffered high indebtedness. In 1901 church was almost $\$ 20000$ behind in salary payments. See: (Richard Schwarz and Floyd Greenleaf, Light Bearers: A History of the Seventh-day Adventist Church, 246-248.)

${ }^{11}$ See; John J. Robertson, A. G. Daniells: The Making of a General Conference President, 1901 (Mountain View, CA: Pacific Press, 1977); Richard W. Schwarz, "John Harvey Kellogg: American Health Reformer" (Ph. D Dissertation, University of Michigan, 1964).

${ }^{12}$ See: Barry David Oliver, SDA Organizational Structure: Past, Present, and Future; Richard Schwarz and Floyd Greenleaf, Light Bearers: A History of the Seventh-day Adventist Church; Richard W. Schwarz, "John Harvey Kellogg: American Health Reformer." 
accepted George Butler's address on one-man leadership as the best leadership model. ${ }^{13}$

His proposed model was deducted from the idea that whenever God raised a movement,

God also chose and empowered the leader for that movement. Based on this philosophy,

James White was elected president of the GC at the next session. Butler considered White to be the leader God had chosen for the Seventh-day Adventist church.

But 1877 brought a shift. Delegates of that year's session concluded that one-man leadership was not the right way forward. Because their statement has so often been used to emphasize the authority of the GC, it deserves to be quoted in its entirety:

Resolved, That we rescind all that portion of the Address on Leadership passed in 1873 , which teaches that the leadership of the body is confined to any one man. Resolved, That the highest authority under God among Seventh-day Adventists is found in the will of the body of that people, as expressed in the dicisions [sic] of the General Conference when acting within its proper jurisdiction; and that such decisions should be submitted to by all without exception, unless they can be shown to conflict with the word of God and the rights of individual conscience. ${ }^{14}$

The emphasis of this statement is not on how much authority the GC has but rather on the dispersion of power from one person to the body of believers. It also includes two important checks and balances: the authority of the GC has to be tested by the word of God, and it must always respect the rights of individual conscience. This statement does not make the GC the ultimate authority, a place which belongs only to God and Scripture. It rather acknowledges the authority of the corporate body over personal ideas and opinions as long as that authority is submitted to the authority of God and the Bible.

\footnotetext{
${ }^{13}$ For more information, see Kevin M. Burton, "Centralized for Protection: George I. Butler and His Philosophy of One-Person Leadership" (MA Thesis, Andrews University, 2015), http://www.academia.edu/19481029/Centralized_for_Protection_George_I._Butler_and_His_Phil osophy_of_One-Person_Leadership, Accessed on February 25, 2016.

${ }^{14}$ A. B. Oyen, "Sixteenth Annual Session of the General Confernce of S. D. Adventists.," The Review and Herald vol. 50, no. 14 (October 4, 1877): 106.
} 
A discrepancy between the theoretical acceptance of the corporate model of leadership and the practice of having power concentrated around strong leaders resulted in not only a power struggle but also in some extreme views on leadership. During the 1890s, responding to the philosophy of one-man leadership, Alonzo T. Jones emphasized the fact that Christ, through His Holy Spirit, must be the only leader in the church. ${ }^{15}$ Based on that idea, he and some of his colleagues formally opposed any kind of human leadership. Applying their ideas literally would threaten the church with disorganization. ${ }^{16}$

Out of the struggle to define and apply an appropriate leadership model of the church organization emerged the issue of kingly power as a defining phrase connected with that struggle. Ellen White used this term to label administrative centralization and the abuse of power by church leaders. ${ }^{17}$ "The pope claims authority over the practice of many who do not recognize Christ as our only Authority," she said in 1903. "He places himself in the position of God, and the weak and uninformed are kept from the knowledge that would reveal to them their privilege as children of God. We are to have

\footnotetext{
${ }^{15}$ Knight explains, “The heart of Jones's doctrine of the church in 1889 (and subsequently) was that 'the church is the body of Christ' and Christ is the head of the Church. 'Christ is head,' he proclaimed, 'not only of the body, but [of] every member of the body, every man. No man is the head of any other man, but Christ is head of every one and all."' Knight, Organizing, 87; "Jones and his colleagues were not alone during the 1890s in their theology that the Holy Spirit would guide each church member independent of structured organization." Ibid., 95.

${ }^{16}$ Ibid., 129. Knight claims that Ellen White saw the end result of the Jones/Waggoner orientation would be disorganization.

${ }^{17}$ As already documented in the first chapter pages 16-20.
} 
no kings, no rulers, no popes among us." ${ }^{18}$ She agreed with Jones that Christ is the supreme authority in His church. While White opposed any leader or group of leaders taking God's place of authority, she supported the church organization with its corporate authority. She called for a reorganization of the church to reflect Christ's headship and decentralization of the authority from one leader to the corporate body of believers-equal and without rulers among them. ${ }^{19}$

The end of nineteenth and beginning of the twentieth centuries found a rapidly growing church with an organization unequipped for this unprecedented growth. Although centralized in Battle Creek, the organization included many independent auxiliary organizations loosely interconnected. Church leaders struggled to satisfy efficiently the needs of the mission spreading all over the world, lacking sufficient resources for their work. Most of the leaders had domineering leadership styles as well. At that time, church leaders who used excessive power, together with a centralization of power in one place and around these autocratic leaders, greatly affected the church.

\footnotetext{
${ }^{18}$ Ellen White, No Kingly Power, Letter 212, 1903. (September 23, 1903, written To the Teachers in Emmanuel Missionary College.) Similar ideas are expressed in the following statement: "It has been a necessity to organize union conferences, that the General Conference shall not exercise dictation over all the separate conferences. The power vested in the (General) conference is not to be centered in one man, or two men, or six men; there is to be a council of men over the separate divisions.... In the work of God, no kingly authority is to be exercised by any human being, or by two or three." (Ellen White, Testimonies for the Church.)

${ }^{19}$ See Ellen White, Testimonies for the Church, vol. 3 (Nampa, ID: Pacific Press, 2002), 493; The General Conference Bulletin: Thirty-Fourth Session, vol. 4, The General Conference of Seventh-day Adventist Church (Battle Creek, MI: The Seventh-day Adventist General Conference, 1901), 26; Ellen White, "Kingly Power: Verbatim Report of Remarks by Mrs. E. G. White, at a Meeting Held in Battle Creek College Library, April 1, at the General Conference of 1901," Spalding and Magan Collection (1985): 162-174, https://m.egwwritings.org/en/book/516.1077\#1078, Accessed on March 8, 2016.
} 


\section{Excessive Power of the Leaders of the Church}

The growth of the church was not followed by delegating power and the inclusion of more people in leadership roles. Church organizations in Battle Creek exercised too much power. The success and growth of institutions put more power in the hands of organizational leaders and the struggle in the church was mainly the conflict between strong personalities in charge of church institutions. Some of them include: A. R. Henry of the Review and Herald; Harmon Lindsay, the GC treasurer; and J. H. Kellogg, the leader of the medical work. These strong leaders influenced church members to pour money in their institutions. ${ }^{20}$ The GC and the local conferences were led by domineering leaders too. ${ }^{21}$ A. Leroy Moore points out that Ellen White during her lifetime reproved every president of the GC for wrong use of authority except John Byington. ${ }^{22}$

In the first 25 years of the church organization two leaders, James White and George Butler, were presidents for 21 years. James White as one of the founders of the church, and supported by Butler's theological ideas, was an authoritarian leader. Butler's

\footnotetext{
${ }^{20}$ For example, R. Henry was able to pull the Review and Herald out of indebtedness by developing a banking system in his institution, and according to Schwarz and Greenleaf he used denominational funds for his personal ventures with justification that profit was used for advance of God's work. (Richard Schwarz and Floyd Greenleaf, Light Bearers: A History of the Seventhday Adventist Church, 249.) Under his leadership the emphasis of the publishing house was on business rather than promoting the Adventist message. In 1897 an investigation chaired by A. T Jones disclosed several abuses in that institution (inappropriate payment and treatment of the workers, inadequate training of young workers, lack of care to provide appropriate sanitary work conditions, and failure to work for the spiritual benefit of non-Adventist). (ibid.) After his removal from the leadership position at the Review and Herald, A. R. Henry initiated a legal battle among the church leadership by suing his former institution in a civil court. Controversy finished by arbitration and attempt of reconciliation.

${ }^{21}$ Ibid., 250.

${ }^{22}$ A. Leroy Morre, "Kingly Power," in The Ellen G. White Encyclopedia, ed. Denis Fortin and Jerry Moon (Hagerstown, MD: Review nad Herald Publishing Association, 2013), 920.
} 
leadership was defined by his own ideas of a strong presidency. ${ }^{23}$ His leadership was additionally defined by the current state of the church organization. All church organizations were operated as quasi-independent institutions, related to but not subject to the GC. ${ }^{24}$ The GC had a five-member executive committee to advise the president, but the leaders did not even live in the same place, which made consultation almost impossible. ${ }^{25}$ This put Butler largely in charge of making decisions by himself, and at the same time in little control over the institutions, over which he was not in charge.

In 1889, during O. A. Olsen's presidency, the GC delegates unsuccessfully tried to resolve the problem. ${ }^{26}$ When G. A. Irwin became president in 1897 he perceived the situation in the church as troubling - the church was in disorder, and everybody was doing as they wished. ${ }^{27}$ Schwarz and Greenleaf point out that "[the] unbridled growth [of the church] prompted those who resided at headquarters to think of themselves as the hub around which the whole denomination turned." 28

\footnotetext{
${ }^{23}$ Richard Schwarz and Floyd Greenleaf, Light Bearers: A History of the Seventh-day Adventist Church, 251.

${ }^{24}$ Butler was the leader of the GC, the Seventh-day Adventist Publishing Association, and the Seventh-day Adventist Educational Society. Stephen N. Haskell headed the Tract and Missionary Association and the Pacific Seventh-day Adventist Publishing Association, W. C. White led the Sabbath School Association, and J. H. Kellogg presided over the Health Reform Institute and American Health and Temperance Society.

${ }^{25}$ Richard Schwarz and Floyd Greenleaf, Light Bearers: A History of the Seventh-day Adventist Church, 251.

${ }^{26}$ They discussed and rejected the idea of incorporating various associations and societies into the conference by naming a secretary at the conference level to oversee those organizations. Nevertheless, in 1901 that model was accepted as the essential structural design of the church. (ibid., 253.)

${ }^{27}$ Ibid., 254.

${ }^{28}$ Ibid., 248.
} 
J. H. Kellogg is another excellent example of the excessive use of power. His strong personality and energetic spirit tended to take charge of and control more than his position required. For example, while his Medical Missionary and Benevolent Association was one of seven other auxiliary organizations, in 1901, "his medical organization controlled nearly 25 percent of the votes (of the Executive Committee of the GC) and had a great deal of sympathy among other committee members." ${ }^{29}$ At the same time, the Sanitarium's charter, written in 1897, claimed nondenominational and nonsectarian status, and de facto proclaimed institutional independence from the church. In an attempt to counterbalance Kellogg's medical branch and his excessive influence, A. G. Daniells, the GC president since 1901, employed similar authoritative methods in his leadership role in the ministerial branch of the church. ${ }^{30}$

\section{Centralization of Power and Activities in One Location}

The centralization of church activities, membership, and institutions at Battle Creek meant that there were fewer resources for other activities and fields. Oliver asserted that the tendency toward centralization of the church in Battle Creek could be observed in the concentration of too much responsibility on individuals or small groups of leaders. He also noted that many church members and institutions were located in the Battle Creek area, and that the GC dominated over state conferences, and that most of the

\footnotetext{
${ }^{29}$ George Knight, Organizing to Beat the Devil: The Development of Adventist Church Structure, 112.

${ }^{30}$ See: Richard Schwarz and Floyd Greenleaf, Light Bearers: A History of the Seventhday Adventist Church, 265-272; Richard W. Schwarz, "John Harvey Kellogg: American Health Reformer," 347-360; John J. Robertson, A. G. Daniells: The Making of a General Conference President, 1901.
} 
leaders had an authoritarian attitude. ${ }^{31}$ Ellen White warned about and wrote against that centralization which, according to Oliver, had two main elements: centralized control and centralized location. $^{32}$

Centralized control was embraced especially by Butler's administration. During his presidency, the centralization of authority was apparent in the tendency of the administration to make the decisions instead of the constituency. In 1883 "Ellen White pointed out that 'every one of our leading men' considered that 'he was the very one who must bear all the responsibilities' and 'failed to educate others to think' and 'to act." "33 At the same time, she encouraged conference leaders to make their own decision. ${ }^{34}$

In the last quarter of the nineteenth century, Battle Creek became the centralized location where were settled the GC and the church institutions. While many church members moved to Battle Creek, the missionary aspirations of the church were negatively affected. As early as 1868 Ellen White made her first appeal for Seventh-day Adventists to move out of Battle Creek to advance the missionary work of the church. ${ }^{35}$ In 1884 the GC session made a similar call. Schwarz and Greenleaf pointed out that "Ellen White counseled that Adventists should establish other centers to equalize the

${ }^{31}$ Barry David Oliver, SDA Organizational Structure: Past, Present, and Future, 125.

${ }^{32}$ Ibid., 57-66.

${ }^{33}$ Ibid., 59.

${ }^{34}$ Ibid., 60.

${ }^{35}$ Ellen White, Testimonies for the Church, vol. 2 (Boise, ID: Pacific Press, 1948), 113115. 
work, ${ }^{\prime 36}$ but even many years later, during Olsen's presidency, her request was fruitless.

She wrote from Australia in 1894,

The work is not to be centered in any one place, not even in Battle Creek. . Mistakes have been made in this line. Individuality and personal responsibility are thus repressed and weakened. The work is the Lord's and the strength and efficiency are not all to be concentrated in any one place. . . I have little faith in the large or small confederacy that is being formed. It looks dark and forbidding to me. ${ }^{37}$

It seems that as long as the institutions were centralized in Battle Creek, most of the church members were not willing to relocate. In spite of all the pressure and counsels, no action of the relocation of the institutions was taken until 1903 in the aftermath of the fires of the sanitarium and the printing house. ${ }^{38}$

While the church and the independent (auxiliary) church organizations were concentrated at the same location, they were sharing all available resources. The struggle over those (usually insufficient) resources and poor communication between auxiliary institutions brought the church to the brink of a schism caused by the already mentioned conflict between the ministerial and medical branches. It became apparent that the church's current organizational structure needed a change. Oliver asserted that the church organization was inadequate because organizational structure from 1863 could neither accommodate the rapidly growing church, nor prevent centralization, nor promote delegation of responsibility. ${ }^{39}$ The question of adequate organizational structures to

\footnotetext{
${ }^{36}$ Richard Schwarz and Floyd Greenleaf, Light Bearers: A History of the Seventh-day Adventist Church, 248.

${ }^{37}$ Ellen White, Testimonies for the Church.

${ }^{38}$ Barry David Oliver, SDA Organizational Structure: Past, Present, and Future, 61-62.

${ }^{39}$ Ibid., 66.
} 
control resources, finances, and manpower had become the most pressing issue in the church. $^{40}$

There are many important leaders who participated in the described events, and all of them exercised and sometimes abused power: presidents of the GC George A. Irwing and Arthur G. Daniells; A. R. Henry, treasurer of the Review and Herald Publishing Association; elders Alonzo T. Jones, W. W. Prescott, A. F. Ballenger, Ellet J. Waggoner, J. N Loughborough, S. N. Haskell, W. C. White, and Dr. John H. Kellogg with the leaders of the institutions he controlled; influential and rich members of church such as the Wessels family; and Ellen G. White, who was accepted by most members as a prophet, which gave her prophetic authority. Potentially, all of these individuals had the opportunity to abuse their power and could be used as examples for analysis. It was already mentioned that because of the limitations of this research, the continuation of this study will analyze the leadership of only two leaders personally involved in the kingly power controversy-A. G. Daniells and J. H. Kellogg.

\section{Short Biography of Two Leaders}

\section{John Harvey Kellogg}

John Harvey Kellogg was one of the most influential leaders among the second generation of Seventh-day Adventist leaders. He was born in Tyrone Township in Michigan in 1852, after the Great Disappointment of the Advent movement (1844) and before the Seventh-day Adventist church was officially organized (1863). Kellogg contributed much to the mission of the church, especially to its health ministry.

${ }^{40}$ See: Erich Walter Baumgartner, "Church Growth and Church Structure: 1901 Reorganization in the Light of the Expanding Missionary Enterprise of the SDA Church" (Term Paper, Andrews University, 1987), 22. 
Nevertheless, in the last forty years of his life, he lived as an outcast and his activities were entirely separated from the denomination. At the same time, according to the available information, he never disputed any of the Church's basic tenets. Alonzo Baker, who was closely associated with Kellogg from 1939 to 1942, described him in the following way: "Kellogg was a Sabbathkeeper and once a Seventh-day Adventist. Whether in the church or not, Doctor Kellogg kept the faith." ${ }^{\prime 1}$

Kellogg was the first son of John Preston Kellogg and his second wife, Ann. Shortly after he was born his parents accepted the teachings of the Seventh-day Adventist church, so he grew up in an Adventist environment. When he was 4 years old his parents moved to Battle Creek, Michigan, which at the time was the center of the church's activities and also the headquarters of the denomination. Young Kellogg read a lot, but he also had an excellent formal education. He attended Battle Creek public schools and Michigan State Normal School, which became in 1959 Eastern Michigan University. Finally he went to New York University Medical College at Bellevue Hospital where he graduated in 1875 with a medical degree. He worked diligently from an early age. First, he worked in his father's broom factory and later in the Battle Creek publishing house. Kellogg married Ella Ervilla Eaton (1853-1920) in 1879. They were foster parents to 42 children, but they did not have any of their own. They legally adopted eight of their foster children. Kellogg died in 1943. As a health reformer, he left a legacy as a visionary who practiced preventive medicine, applied modern inventions in the medical

\footnotetext{
${ }^{41}$ Alonzo L. Baker, "My Years with John Harvey Kellogg," Spectrum Autumn 1972
} (1972): 45. 
field, used many nonconventional methods, and who invented certain breakfast foods so common in the supermarkets and on our tables today.

In 1876 he became the physician-in-chief of the Health Reform Institute, mostly by the influence of James White who was, together with Ellen White, his sponsor and supporter. During that year he significantly improved the situation at the Institute, which had been on the brink of bankruptcy. He later changed the name of the Institute to the Battle Creek Sanitarium. "The doctor explained that the new name he coined, a variant of 'sanatorium,' would come to mean a 'place where people learn to stay well." ${ }^{\prime 42}$ During the 1880s the Sanitarium came under Kellogg's control. In 1885 he became the first nonclergy chairman of the board of directors. "By then the directors had become so convinced that the sanitarium's growing prosperity depended upon Kellogg's continued presence that they refused to face the prospect of losing him. Instead those who opposed Kellogg had to go." ${ }^{43}$ Kellogg used his influence upon the directors to keep his position of authority and power. When faced with opposition he would just threaten the board with his resignation. Although he accepted the position of physician-in-chief for only one year, he led the institution for 67 years.

The most important part of Kellogg's biography for this study is his leadership position at the Battle Creek Sanitarium and in the Seventh-day Adventist Church at large, and his relationship with the leaders of the denomination, particularly the president/chairman of the church A. G. Daniells. The remainder of this study examines

\footnotetext{
${ }^{42}$ Richard W. Schwarz, John Harvey Kellog, M.D. - Pioneering Health Reformer (Hagerstown, MD: Review and Herald Publishing Association, 2006), 65.

${ }^{43}$ Ibid., 66.
} 
how both the doctor and the man who would become his adversary, Daniells, used or misused their power.

\section{Arthur Grosvenor Daniells}

Arthur G. Daniells is best known as the president of the GC, a position he held longer than any other president - twenty-one years. He was born in West Union, Iowa on September 28, 1858. He lost his father Thomas at the age of five. After the death of his father, who was an Army physician and died during the Civil War, he worked as a farmer on the farm of his stepfather. His mother, Mary Jane, was baptized into the Seventh-day Adventist Church in 1865 and Arthur was converted and baptized at the age of ten in 1868.

A few years later, because of his urge to get an education, he left home. In the beginning, he worked and went to school in Iowa. His first job for the Seventh-day Adventist Church at the age of sixteen was selling a "Health Almanac." At the age of seventeen he entered Battle Creek College with eighty dollars his mother saved from his father's pension. Because of his poor health, he studied there for only one year. In Battle Creek, he met Mary Ellen Hoyt and they were married in November of 1876.

In 1877 he was troubled by a call that had been ringing in his head: "Go work in My vineyard." ${ }^{44}$ He was perplexed because he had a speech impediment. He felt that this handicap excluded him from public work. Nevertheless, under the pressure of this calling, he decided to follow his conviction.

\footnotetext{
${ }^{44}$ According to: John J. Robertson, A. G. Daniells: The Making of a General Conference President, 1901, 15.
} 
The Iowa Conference committee's president, E. W. Farnsworth, rejected him as a ministerial candidate. Instead of quitting, he became determined more than ever to work in God's vineyard ${ }^{45}$ It seems that he was already showing the traits of determination and persistence we will see during his presidency years later. But it can also be noted that his character development was a consequence of the struggles and obstacles the young Daniells had to overcome.

In 1878 Arthur Daniells started his denominational work, first as a tent master under R. K. Kilgore and later as a secretary to James and Ellen White. In 1880 G. I. Butler invited him to preach, and that year he received his ministerial license. He was ordained two years later. That led to his first leadership appointments and involvement in city mission work. In 1886 the GC sent him to New Zealand. At that time, he was only the third Adventist minister sent south of the equator. Continuing the work of S. N. Haskell, by 1891 he developed a conference of approximately 250 members. That year, because of his poor health, he moved to Australia. There he became the president of the conference the following year. After eight years in Australia, he visited South Africa and England in 1900 on his way to the 1901 session of the General Conference.

In 1901 he was elected to be the chairman of the GC Committee, and he was in that leadership position until 1922. For the last thirteen years of his life he was first the secretary of the GC and then the secretary of the ministerial association of the church.

A. G. Daniells spent almost fifty years of his life holding leadership positions in the Church. It is not surprising that he also faced many challenges as he wielded his power in these various positions. Describing his leadership, McArthur points out that

${ }^{45} \mathrm{Ibid}$. 
Daniells' legacy can be defined according to three convictions. First, he believed in and practiced the three angels' message, and he persuaded the church to take it to the world. Second, he affirmed the prophetic ministry of Ellen White. And third, he was convicted that Adventist ministry must be more professional and present the truth of righteousness by faith in a better way." ${ }^{46}$ John J. Robertson writes: "His strengths also involved his weaknesses. It is not always easy to draw the line between rigidity and firmness, policy and principle, kingliness and dignity, definiteness and sharpness, organization and freedom, drive and intemperance, intensity and inconsiderateness, administrative ability and favoritism. ${ }^{.47}$

\section{The Relationship between Kellogg and Daniells}

It was 1900 and A. G. Daniells was on his way from Australia to the United States. While he stopped in Europe, there was a rumor going around in Battle Creek started by Kellogg. Kellogg stated at a meeting of the board of the Benevolent Association that there was a scheme in place in Australia to appoint Daniells as the President of the GC and W. C. White as President or Secretary of the Foreign Mission Board. This information was allegedly based on information from John Wessels, who traveled with Daniells on part of his trip. According to the doctor, that is how W. C. White would be able to indirectly control the GC - by controlling Daniells. Kellogg was not bothered by the presence of Irwin - the current President of the GC - when he

\footnotetext{
${ }^{46}$ Benjamin McArthur, A.G. Daniells: Shaper of Twentieth-Century Adventism (Nampa ID: Pacific Press, 2015), 11.

${ }^{47}$ John J. Robertson, A. G. Daniells: The Making of a General Conference President, $1901,115$.
} 
presented the issue. ${ }^{48}$ E. G. White responded to Irwin's account of the event with the claim that she was not aware of any conspiracy and that it was only a fabrication. ${ }^{49}$

Consequently, it is surprising that in the following year, during the 1901 session of the GC, Kellogg was the one who made the motion to elect Daniells as the Chair of the GC Executive Committee. Was Kellogg's move a personally orchestrated plot, or part of the political game? It is hard to say. We do not know if Kellogg wanted to draw attention to himself by proposing the "obvious" choice, somebody who would be elected anyway or if he wanted to make the new chair feel obligated to return him the favor. We also do not know if this course of action was followed because he believed that Daniells was "manageable" and that Kellogg could easily influence him. But it is evident that politics were involved.

In the aftermath of the 1901 session of the GC, it appeared that the two branches of the church, medical and ministerial, would finally start to work together. And it seemed that the two leaders were willing to cooperate. Kellogg even stated that Daniells is "the man for the place" and that he would help to overcome the breach between the medical and evangelical branches of the church. ${ }^{50}$ But as was already mentioned, their relationship quickly deteriorated.

\footnotetext{
${ }^{48}$ Gilbert M. Valentine, The Prophet and the Presidents (Nampa, ID: Pacific Press, 2011), 182.

${ }^{49}$ Ibid., 186.

${ }^{50}$ Richard W. Schwarz, "John Harvey Kellogg: American Health Reformer," 394. Based on: (Kellogg to E. G. White, September 6, 1901, June 27, 102, E. G. White Papers; Kellogg to Elder J. A. Burden, Ma 1 1901, Burden Papers, Loma Linda, CA: Loma Linda University.)
} 
McArthur points out that the three sources of conflict between Kellogg and the church were: 1) the "no debt" policy of the GC, 2) the ownership of the institutions, and 3) the rebuilding of the Sanitarium in addition to Kellogg's book The Living Temple and its pantheism. ${ }^{51}$ Valentine defines these sources of conflict as a difference in administrative policy, in understanding the mission of the church, and in theology. ${ }^{52}$ Describing the conflict between Kellogg and Daniells, Percy T. Magan asserted: "That was a fight between Daniells and Kellogg; no kingdom can have two kings at one time. ${ }^{153}$

The first big fight between the two leaders was caused by Kellogg's attempt to persuade Daniells to borrow money for the establishment of a health institution in England and to disregard the new "cash policy" of the GC. The intensity of the conflict generated a considerable amount of animosity between the two leaders.

Kellogg's reaction was hostility expressed by challenging Daniells' leadership by claiming that he was not a strict vegetarian. In addition, he stated that he was acting in "a kingly way." Finally, Daniells' statement that Kellogg had "an imperious will" which needed to be broken contributed to the increase in the intensity of the conflict. ${ }^{54}$ In addition to fiscal policy, the conflict between the two leaders was also fueled by the struggle for control over certain independent church organizations. Kellogg was

${ }^{51}$ Benjamin McArthur, A.G. Daniells: Shaper of Twentieth-Century Adventism, 185.

${ }^{52}$ Gilbert M. Valentine, W. W. Prescott: Forgotten Giant of Adventism's Second Generation (Hagerstown, MD: Review and Herald, 2005), 167.

${ }^{53}$ Quoted from: Alonzo L. Baker, "My Years with John Harvey Kellogg," 43.

${ }^{54}$ Richard W. Schwarz, "John Harvey Kellogg: American Health Reformer," 395. Quoted from Dr. Kellogg's letters to Butler and Ellen White. 
very responsive to the desire of certain church leaders for him to take control of the medical work. He did not believe that a preacher had any business in a medical institution, and he wanted to maintain his control of the medical work. ${ }^{55}$ Kellogg considered clergy intellectually inferior to the new professional class in the church medical workers. ${ }^{56}$ Church leaders worried that he wanted to take control over the entire church. $^{57}$

Another issue of disagreement was the decentralization of the church's activities together with the moving of the church institutions to a new place, which led to an exodus from Battle Creek. Kellogg perceived this trend as a threat to his work. By establishing the independent educational institutions - a new Battle Creek College, Kellogg attempted to counterbalance the trend and reverse the process. ${ }^{58}$

The struggle caused by their disagreement over theology includes the following issues: Kellogg favored a very liberal use of the tithe, he considered large portions of Scripture as figurative including those with prophecies important to Adventist theology, he questioned the teachings and inspiration of E. G. White, and he propagated some

${ }^{55}$ Ibid., 378.

${ }^{56}$ Benjamin McArthur, A.G. Daniells: Shaper of Twentieth-Century Adventism, 185.

${ }^{57} \mathrm{McArthur}$ asserts that, "the Battle Creek Sanitarium was closely identified with the Seventh-day Adventist church, but was essentially his [Kellogg's].” (ibid., 184.)

${ }^{58}$ Richard W. Schwarz, "John Harvey Kellogg: American Health Reformer," 383. According to Schwarz, Kellogg was making fun of leaders who were precipitating the exodus by focusing on possible catastrophic events; but he was talking about the protection of church property during end time events to support the independence of his institution at the 1903 session of the GC. See: (Benjamin McArthur, A.G. Daniells: Shaper of Twentieth-Century Adventism, 195-196; "The General Conference Bulletin: Thirty-Fifth Session," The General Conference of Seventh-day Adventist Church, April 6, 1903.) 
possibly pantheistic ideas. ${ }^{59}$ Kellogg also defied the divine inspiration of Ellen White's writings by claiming that he had inspired some of them himself. Daniells considered this claim extremely dangerous. ${ }^{60}$

In his reaction to these issues, and to counterbalance Kellogg's influence, Daniells demanded that the leaders of the church denounce Kellogg and remove all those who did not comply with his request. ${ }^{61}$ The behavior of the church leadership did not help to mitigate the tension. Eight months after the 1901 session, Kellogg described the new administration as "a hard-fisted administration" determined to make his life miserable. ${ }^{62}$ That was followed by a failed attempt to remove Daniells from his leadership position. As the tension grew, everyone was aware of the seriousness of the situation and some leaders tried to reconcile the fighting factions.

Two leaders that Kellogg considered his allies, especially from the time they united to limit James White's influence, were G. I. Butler, former GC president, and S. N Haskell, the church's leading evangelist and author. Even though Kellogg warned them that they might get in trouble with the "Washington ring," they attempted to reconcile the

${ }^{59}$ See: Richard W. Schwarz, "John Harvey Kellogg: American Health Reformer," 385394. For detailed description of theological issues in The Living Temple see: Brian C. Wilson, Dr. John Harvey Kellogg and the Religion of Biologic Living (Bloomington, IN: Indiana University Press, 2014), 82-105. It is also interesting that initially Daniells had not seen any theological issue with Kellogg's book. He wrote to W. A. Spicer: "There is nothing in it I do not fully endorse." This is due to a lack of understanding because it later becomes a political weapon. (Benjamin McArthur, A.G. Daniells: Shaper of Twentieth-Century Adventism, 188-189.)

${ }^{60}$ Richard W. Schwarz, "John Harvey Kellogg: American Health Reformer," 395.

${ }^{61}$ Ibid., 396. (Based on: P. T. Magan, MS diary, March 5, 1904; Magan to W. A. Spicer, August 6, 1928; Magan to Herbert G. Childs, July 31, 1939, Mega Papers; Sadler interview, September 22, 1960.)

${ }^{62}$ Quoted from: ibid., 391. (From: Kellogg to S. N. Haskell, November 26, 1902.) 
two sides. They tried to mediate between the two sides by not identifying with the doctor's cause, but rather asked him to cease his criticism of Ellen White, confess his sins, be meek and patient, and renounce pantheism. At the same time, they appealed to the Adventist leaders not to be so harsh on the doctor and wrote E. G. White letters in favor of the doctor and his work. ${ }^{63}$

There were three major attempts at reconciliation between the fighting factions. The first one occurred after the 1903 General Session of the GC at the legal meeting of the Medical Missionary and Benevolent Association in Battle Creek, MI. The mediator at that meeting was A. T. Jones, who read the testimonies in which E. G. White urged for the unity of the medical and the evangelical work. Then he presented her personal testimony in which she appealed to the doctor to make an effort to reconcile with the church leadership. Kellogg announced that he would accept the testimony as a message from the Lord and the following day he confessed his errors and asked for forgiveness. Prescott and Daniells did the same. Then they went to the Battle Creek Tabernacle where they announced that all their differences had been resolved. Daniells pointed out that neither man surrendered, but they rather decided to "differ peacefully." They settled all differences without discussing them. It was no surprise that this peace only lasted a few weeks. ${ }^{64}$ Ellen White blamed Kellogg, who did not reform his belief or actions, for the renewed enmity.

\footnotetext{
${ }^{63}$ Ibid., 397. (Based on the following correspondences: Haskell to Kellogg, October 14, 1904, September 26, November 12, 1905; Butler and Haskell to Kellogg, May 27, 1904; Butler to Kellogg, January 2, 1905; Butler to E. G. White, May 12, 1904.)

${ }^{64}$ Ibid., 398-399. "The peace which has come is a permanent peace. All our difficulties have been settled without being discussed." (From Medical Missionary Conference Bulletin (Battle Creek, MI, 1903) as quoted in ibid., 398.)
} 
The second effort at reconciliation happened at a conference of Adventist leaders in Washington D. C. in October 1903. It was led by P. T. Magan, who had a report from his recent visit with E. G. White. During Magan's interview with the Doctor, Kellogg indicated his willingness to dedicate himself to preaching and healing of the sick while he would let the brothers manage the institutions. He denounced his criticism of E. G. White and promised the leaders that he was ready to give up his plan to control all Adventist medical work and that he would remove all heretical theological references from The Living Temple. ${ }^{65}$ This was one of the rare occasions where the doctor really humbled himself. After his meeting with Prescott and Daniells it once again seemed that unity had been achieved. Nevertheless, a few months later the hostility arose again. Kellogg felt that in spite of his efforts to fulfill his promises, the other side pushed him too far. ${ }^{66}$ The very last attempt at reconciliation occurred during a regional meeting of Adventist leaders in Berrien Springs, MI in May of 1904. Before the meeting, the doctor indicated his willingness to resign from his position of leadership in the Medical Missionary and Benevolent Association. Schwarz assumes that Butler's and Haskell's advice not to do so, helped him to change his mind. Although Kellogg had not planned to attend the meeting, he later arrived with a group of his supporters. ${ }^{67}$

The attempt at reconciliation at this meeting was led by E. G. White. Her attempt came after Prescott's hostile attacks against Kellogg's pantheism and the counterattack of

${ }^{65}$ Ibid., 399.

${ }^{66}$ Ibid., 400. (Kellogg to Butler, January 12, 1904, MSU Kellogg Papers; Kellogg to W. W. Prescott, January 16, 1904, E. G. White Papers.)

${ }^{67}$ Ibid. 
A. T. Jones on Prescott's previous pantheistic teachings ${ }^{68}$ Ellen White very vigorously and personally appealed for unity ${ }^{69}$ While Adventist leaders responded to her call with repentance and confession, this time the doctor declined to do the same. When Ellen White reproved him for gloating and refusing to repent, Kellogg left the meeting with the excuse that he had to catch a train. This unsuccessful attempt at reconciliation was soon followed by his voluntary bankruptcy of the Medical Missionary and Benevolent Association to cut off the finances of the GC administration. In response his institution was separated from the Adventist church. In 1907 the Battle Creek Seventh-day Adventist Church disfellowshiped him from the church's membership. Kellogg never reconciled with Daniells. ${ }^{70}$

The struggle between these two leaders reveals several crucial issues in the area of leadership. The most important question in these matters is not who is right or which ethical system should be used. The most important question is what is right. The correct answer to that question will determine which ethical method to use and which course of action to take. Whenever we substitute what with who, we are heading toward personal conflict, self-validation, and abuses of power.

\footnotetext{
${ }^{68}$ Jerry Moon, W. C. White and Ellen G. White: The Relationship Between the Prophet and Her Son, vol. 19 (Berrien Springs, MI: Andrews University Press, 1993), 304-305.

${ }^{69}$ In her sermon she described the unity she appealed for: "What kind of unity is spoken of in these words? Unity in diversity. Our minds do not all run in the same channel, and we have not all been given the same work. God has given to every man his work according to his several ability. There are different kinds of work to be done, and workers of varied capabilities are needed. If our hearts are humble, if we have learned in the school of Christ to be meek and lowly, we may all press together in the narrow path marked out for us." (Ellen White, Sermon: A Plea for Unity, May 22, 1904, MS 52, Letters and Manuscripts, Berrien Springs, MI.) 113.

${ }^{70}$ Brian C. Wilson, Dr. John Harvey Kellogg and the Religion of Biologic Living, 109-
} 
The Socio-political Context of the Issue of Kingly Power

In his article "The Nearly Adventist President," Bill Knott discusses the relationship of Adventists to the United States president Harding. That relationship was based on family relationships of the United States president with the members of the Seventh-day Adventist church, connections that relationships created and the excitement of Adventists of that era with that connection. ${ }^{71}$ Similarly, we can learn more about the leadership of Daniells and Kellogg by considering the interrelation of their Christian leadership with the leadership of their secular political contemporaries. Thus, this study explores the larger context of an interaction of Christian leadership with society and politics, then briefly observes the social and political context of the era in which the kingly power issue emerged, and finally searches for the possible relations of the leadership style of the church leaders this study analyzes the leadership style of their contemporaries, particularly the president of United States Theodore Roosevelt.

\section{The Larger Context of an Interaction of Christian Leadership with Society and Politics}

Leadership is an influence. It has a relational dimension that causes leaders to be influenced by those around them. While in the position of influencing their followers, all leaders, and spiritual leaders are no exception, are influenced by other leaders, society, environment, and circumstances. Subordinates, especially in spiritual leadership, are supposed to exercise their influence on their leaders as well.

\footnotetext{
${ }^{71}$ List of his Adventist relatives includes: the president's mother, Phoebe, and his aunt, Sarah Priscilla Flack, younger sister Carolyn, his brother-in-law Heber H. Votaw, an Adventist minister, his brother, George, Jr., presidential nephews George III and Charles, and according some account his sisters Abigail, Mary, and Charity. (Bill Knott, "The Nearly Adventist President," Adventist Review, January 26, 2006.)
} 
The tendency of Christian leaders to reflect the social climate that affects leaders outside the church can be noticed. The church and the church's leadership practices might reflect their culture and society. The depiction of some examples might be sufficient to indicate the extent of that interaction of influences.

A good biblical example is the election of the first Jewish king. At that time Samuel was priest and judge, and Israel had no king. Israelites considered God their supreme leader, and their social and political affairs were managed by judges and prophets. The freedom and prosperity of the whole nation often depended on the quality of those leaders and their adherence to moral principles. But eventually, Israel wanted a king. Alden Thompson emphasizes their reason: "they wanted to be like the nations around them..72 They wanted to have a leader who would lead them in a way similar to the leaders of other nations. The influence of the surrounding culture dictated their choices. Being different is hard. Saul did not become king because of his desire, nor because this was the real need of the people of Israel. He became the king because of the influence of the neighbors of Israel. And these influences affected his leadership.

Martin Luther can also be observed as a historical example. While he was one of the most celebrated figures of the Reformation, he was not without his faults-flaws that were influenced by his historical context. For example, during the Peasant War, Luther labeled the peasants as "mad dogs." From the perspective of contemporary philosophy, ethics, and understanding of contemporary theology he was wrong. While his attitude seems strange, it is a good example of how this brilliant leader was not able to avoid all

\footnotetext{
${ }^{72}$ Alden Thompson, Samson, The Abundant Life Bible Amplifier, (Boise, ID: Pacific Press Publishing Association, 1995), 80.
} 
the influences of his time. Lloyd Volmark explains in his book Luther's Response to Violence, "The logical place to begin is with Luther's world for he can be understood only within the framework of that age which produced him ..."73 "The world that produced Luther involved not only ecclesiastical situation, but also social structures, economic condition, and political institutions. All these factors were closely intertwined. ${ }^{74}$ While modern Christian ethics condemn Luther's statements about peasants, the majority of his contemporaries would have seen no problem. His positions were influenced by his society and reflected his culture, and theology and philosophy of his time.

Zdravko Plantak points out in his book The Silent Church another sad example of the influence of abusive politics on spiritual leadership. Under the pressure of the Nazi regime, 99.9 percent of voters in the mostly Adventist town of Friedensau in Germany voted for the Nazi parliamentary state. Wilhelm Mueller, the President of the Seventhday Adventist East German Conference, stated that the refusal to salute the Swastika flag and to use the Hitler greeting was bad for the image of the church "that under no circumstances did any Adventist have the right to resist the government, even if the government prevented him from exercising his faith. The resistance would be unfortunate because it would mark Adventists as opponents of the new state, a situation that should be prevented." 75 While the motivations and reasons for such extreme positions can be 26.

${ }^{73}$ Lloyd B. Volmark, Luther's Response to Violence (New York: Vantage Press, 1974),

${ }^{74}$ Ibid., 33.

${ }^{75}$ Zdravko Plantak, The Silent Church (London: MacMillan Press LTD, 1998), 18. 
questioned, it is striking how far that Christian leader strayed from the biblical ideal because of the political influence, strong propaganda, and political pressure.

In all mentioned examples, we can see how the influences surrounding the church affected the leaders and communities of believers. These examples are sufficient to assume that spiritual leaders are exposed to the surrounding influences, and often their leadership styles and patterns reflect those influences. Additionally, sometimes the spiritual community expects their leaders to follow known leadership styles and patterns of their culture and society. Both the exemplary influence of society and expectation of subordinates contribute to a tendency of the spiritual leaders to imitate the leadership style of the political leaders of their time.

\section{The Times of Kellogg and Daniells}

The world of Kellogg and Daniells was complex. George Mowry expresses the challenge of depicting that world. "Confronted with the turbulent world of 1900, fairly seething with economic and technological change, with strange new scientific and religious ideas, with the growth of giant industry and organized labor, and with the rapid and uproarious rise of 'the alien city,' thinking Americans divided politically into ideological groups which in their bewildering diversity almost defy analysis."76

Both Kellogg and Daniells were children during the American Civil War (18611865), and grew up in a time of unrest, struggle, and fear. Daniells's father was an army physician and surgeon who died in the war. While we can safely assume the war affected

\footnotetext{
${ }^{76}$ George E. Mowry, The Era of Theodore Roosevelt, 1900-1912 (New York: Harper \& Brothers, 1958), 38.
} 
their notions of leadership, the specifics of their upbringing are beyond the scope of this work.

The post-war Victorian era is most frequently associated with architecture, but the context of that influence is much wider. William Allen White, points out that Theodore Roosevelt was the president of a country that since the 1850s was transitioning from rural and individual toward highly socialized and industrial. ${ }^{77}$ Mowry explains, "American society in 1900 was thus rent by two major forces propelling it in acutely different directions. Material changes and institutions were creating a highly differentiated society.

Simultaneously the new intellectual and moral creed were demanding a return to a more equalitarian life. The conflict between the two forces was inevitable..."78

The Victorian Era upheld honor, duty, moral seriousness, and sexual morality as high values. The world was divided between colonial powers fighting for domination and resources. That was also a world of unprecedented technological progress and industrial revolutions. At the same time, it was a time of the brutal factory conditions (6 days of 12 hours of labor), low wages, and crowded cities. With the migration from the country to the cities, the middle class emerged. It was a time of industrial progress, but also of poverty, with many suffering from dangerous working conditions and overpopulationinduced diseases.

On the religious scene, this was the age of the rise of secularism and religious skepticism affected by Darwinism and the Theory of Evolution. David Burton depicted the shift in thinking,

${ }^{77}$ William Allen White, "Theodore Roosevelt," in Theodore Roosevelt: A Profile, ed. Morton Keller (New York: Hill and Wang, 1967), 18.

${ }^{78}$ George E. Mowry, The Era of Theodore Roosevelt, 1900-1912, 37. 
The decades from 1858 to 1919, years marking [Theodore Roosevelt's] lifetime, were times of intellectual transition in America... The mid-nineteenth-century American mind had possessed a strongly traditional quality... At the center of this faith [religion held by most Americans] was supernaturalism, buttressed by a system of philosophical absolutism... its impact [publishing The Origin of Species] on American thought in Roosevelt's formative years was far-reaching. Darwin's book, with its principles popularized and applied to social conditions, derived a grave blow to the supernaturalism that was central to American Protestant Christianity. ${ }^{79}$

Reflecting on the influence of Darwinism on society, Sarah Watts asserted that "...the social Darwinism of Roosevelt's era made it easier to entwine racial, masculine, and national trajectories with that of civilization itself." ${ }^{\prime 80}$ It was a man dominated society with prescribed gender roles, men as breadwinner and women the care-taker. David Burton suggested three main ideas that the society of the time derived from Darwin's theory. "Three ideas critical to American thought as it developed out of Darwinism fascinated Rosevelt's generation: changeability, progress, and a material order." ${ }^{81}$ Such positions obviously affected the leadership and leadership styles of any leaders.

Watts, in her description of the Victorian mindset, explained the effects of such mindset on leadership. "If indeed retribution elicits pleasure, it is possible that the more concerned the Victorian bourgeoisie grew with protecting its own moral interest against degenerate behavior, and the more desperate it became in its search for social order, the

${ }^{79}$ David H. Burton, The Learned Presidency: Theodore Roosevelt, William Howard Taft, Woodrow Wilson (Rutherford: Fairleigh Dickinson University Press, 1988), 41.

${ }^{80}$ Sarah Watts, Rough Rider in the White House: Theodore Roosevelt and the Politics of Desire (Chicago: The University of Chicago Press, 2003), 21.

${ }^{81}$ David H. Burton, The Learned Presidency: Theodore Roosevelt, William Howard Taft, Woodrow Wilson, 42. 
more it accepted social violence as morally justified. ${ }^{~} 82$ The more concerned leaders became with preserving moral older, more persistent they had to be to keep that order. This created a demand for strong leaders.

Julian Marias pointed out in his book History of Philosophy that two dominant trends in Anglo-Saxon thought at the end of the nineteenth century and continuing into the twentieth century are pragmatism and personalism. It is not surprising that some of those trends can be observed in the leadership of Kellogg and Daniells. ${ }^{83}$

Affected by all those elements is the emergence of the progressive movement at the beginning of the twentieth century. George Mowry depicted that movement as a combination of

A belief in open universe in which man was neither chained to the past nor riding on an automatic escalator into the future was central to the creed. Also at its heart was a belief in the doctrine of possible progress based upon the twin assumption that man was more good than he was evil and that he had power through his intellect and moral sense to change his environment. Devotion to Christian ethics, if not to Christian mysticism, and an ardent desire to apply such ethics to the daily life of the commonwealth, also motivated progressive thinking. ${ }^{84}$

An analysis of the leadership of Daniells and Kellogg will reveal some elements of the progressive movement in the leadership of Kellogg and Daniells. A logical conclusion of such observations, but one which cannot be conclusive without future study, is that their leadership was affected by their society. Nevertheless, there are some striking similarities in the leadership traits and style of one of the most famous

${ }^{82}$ Sarah Watts, Rough Rider in the White House: Theodore Roosevelt and the Politics of Desire, 17-18. 402.

${ }^{83}$ Julian Marias, History of Philosophy (New York: Dover Publications Inc., 1967), $393-$

${ }^{84}$ George E. Mowry, The Era of Theodore Roosevelt, 1900-1912, 58. 
progressive of that time, the president of the United States, Theodore Roosevelt. While this study does not allow for a careful comparison of Roosevelt with the leaders analyzed in this study, the conclusion of this section will suggest a potential influence of the United States president on the leadership style and patterns of Daniells and Kellogg. It can also be used as the introductory point for future studies of those influences.

\section{Theodore Roosevelt - "the elected king"}

Theodore Roosevelt was born in 1858 and died in 1919. He served as president from 1901 until 1909, contemporaneously with the period of the kingly power controversy between Kellogg and Daniells. All three leaders were shaped by Civil War stories of suffering, dying, but also about great visionary and heroic war leaders. Such leaders had to overcome obstacles, had a vision and determination and had to change the world around themselves. It should not be a surprise to observe post-war leaders reflect such traits in their leadership.

While there is no direct link between our church leaders and Roosevelt, Schwarz pointed in his study that in 1910 Kellogg shared the platform with former president Theodore Roosevelt at Austin, Texas. ${ }^{85}$ Nevertheless, more important for this study than an incidental speech appointment is the fact that some historians use similar terminology used in the kingly power issue to describe Roosevelt's presidency. In his book on

${ }^{85}$ Richard W. Schwarz, "John Harvey Kellogg: American Health Reformer” (Ph. D Dissertation, University of Michigan, 1964), 206. - Based on Battle Creek Daily Journal from October 21, 1910. 
American presidents Stephen Graubard titles the chapter about President Theodore

Roosevelt "To Be a King” comparing his presidency to kingship. ${ }^{86}$ He writes:

Here was a king without courtiers, a man [Theodore Roosevelt] who insisted to his friend, Trevelyan, that "if it were not for the certainty of fools misunderstanding the terminology, and failing to see that a short-term elective King has nothing whatever in common with a hereditarily King, I could best express to a foreign the President's power by putting it in that form." The president, Roosevelt suggested, never reigned as hereditary monarch did but governed "most actively for four years" as an "elective King." 87

While Daniells and Kellogg rejected the notion that they used kingly power but rather accused each other of kingship, Roosevelt readily admitted his autocratic leadership style.

One reason may be that a political or business leadership does not reject the autocratic leadership style in a way spiritual leadership does. Roosevelt always supported

presidential authority when emphasizing his Commander-in-Chief position. ${ }^{88}$

He wrote the British historian George Otto Trevelyan: "While President, I have been President, emphatically; I have used every ounce of power there was in the office and I have not cared a rap for the criticisms of those who spoke of my 'usurpation of power.' ... The efficiency of this Government depends upon possessing a strong central executive, and wherever I could establish a precedent for strength in the executive, I did." ${ }^{89}$

It is no surprise that historians concur in the description of Roosevelt's strong leadership. Lewis Gould in The Presidency of Theodore Roosevelt said: "Theodore Roosevelt wanted to be a great president." He advocated for a strong presidency, and his

\footnotetext{
${ }^{86}$ Stephen Graubard, Command of Office: How War, Secrecy, and Deception Transformed the Presidency from Theodore Roosevelt to George W. Bush (New York: Basic Books, 2004), 69.

${ }^{87}$ Ibid., 101.

${ }^{88}$ William E. Leuchtenburg, The American President: From Teddy Roosevelt to Bill Clinton (Oxford University Press, 2015), 55.

${ }^{89}$ Ibid., 39.
} 
practice followed his ideology. ${ }^{90}$ Graubard pointed out Roosevelt's high regard for Alexander Hamilton who advocated a strong central government. ${ }^{91}$ William E. Leuchtenburg pointed out Roosevelt's "Hegelian conception of the primacy of the state," and compared his leadership to the German autocrat Bismarck, ${ }^{92}$ and also noticed that Roosevelt was called "America's only Nietzschean president."93 Stuart Sherman compares Roosevelt's leadership to that of Roosevelt's hero, Oliver Cromwell. ${ }^{94}$ In his depiction of Roosevelt's presidency, John Bassett said that he "was aggressive by Nature, a reformer who had forced his acceptance by party leaders because of his blunt way of winning the confidence of people." 95 Roosevelt's presidency was often described by the

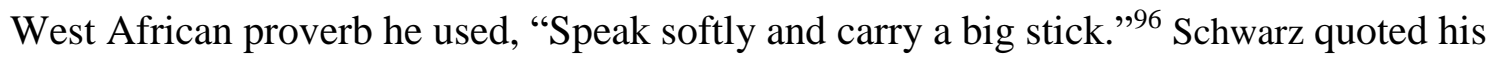
words, "I would not shoot conscientious objectors, but I would lead them to a place

\footnotetext{
${ }^{90}$ Lewis L. Gould, The Presidency of Theodore Roosevelt (Lawrence, KS: University Press of Kansas, 1991), 300.

${ }^{91}$ Stephen Graubard, Command of Office: How War, Secrecy, and Deception Transformed the Presidency from Theodore Roosevelt to George W. Bush, 101.

${ }^{92}$ William E. Leuchtenburg, The American President: From Teddy Roosevelt to Bill
} Clinton, 37.

${ }^{93}$ Ibid., 39.

94،, ...His strength, his intensity of conviction, his delight in exercising powers for what he conceived to be good ends; his dislike for speculative reforms and his inability to appreciate the necessity of theories to a practical man who wishes to do good work. . . all these tendencies worked together to unfit him for the task of helping a liberty-loving people on the road to freedom." (Stuart P. Sherman, "Roosevelt and the National Psychology," in Theodore Roosevelt: A Profile, ed. Morton Keller (New York: Hill and Wang, 1967), 51.)

${ }^{95}$ John Spencer Bassett, A Short History of the United States, 1492-1920 (New York: The Macmillan Company, 1925), 829.

${ }^{96}$ Quoted in: William E. Leuchtenburg, The American President: From Teddy Roosevelt to Bill Clinton, 40. 
where they would be shot at!"97 His involvement in the Spanish-American war gave him the notoriety that helped make him the president of the United States. ${ }^{98}$ In spite of his militant and aggressive rhetoric he became the first American to win the Nobel Peace Prize for his successful mediation in the Russo-Japanese War. ${ }^{99}$

While strong leadership in the politic arena is not necessarily the sign of power abuse, there are some examples of Roosevelt overstepping, or at least overextending, his authority. Leuchtenburg depicted how in 1906 Roosevelt arbitrarily punished without due process the soldiers of color after the Brownsville, Texas incident. When his actions were challenged in the Senate, he hired private detectives to fabricate the evidence to make his decision look correct. When his action was challenged by a senator, he angrily claimed that he would use his power of veto to prevent any action of the US Senate. ${ }^{100}$ Gould depicted the President,

His authority "was limited only by specific restrictions and prohibitions appearing in the Constitution or imposed by the Congress under its constitutional powers." There was no need to wait for "some specific authorization" to take a needed action in the public interest. Instead, the chief executive should act, "unless such action was forbidden by the Constitution or by the laws." As Roosevelt phrased it in his autobiography, "I did not usurp power, but I did greatly broaden the use of executive power." 101

${ }^{97}$ Richard Schwarz and Floyd Greenleaf, Light Bearers: A History of the Seventh-day Adventist Church (Nampa, ID: Pacific Press, 2000), 369.

${ }^{98}$ Stephen Graubard, Command of Office: How War, Secrecy, and Deception Transformed the Presidency from Theodore Roosevelt to George W. Bush, 79.

${ }^{99}$ William E. Leuchtenburg, The American President: From Teddy Roosevelt to Bill Clinton, 54-55.

${ }^{100}$ See: ibid., 51.

${ }^{101}$ Lewis L. Gould, The Presidency of Theodore Roosevelt, 197. 
He acted independently of other branches of government and against their decisions when he disagreed with them. He claimed that although the Constitution did not give provision for such unilateral action, it did not forbid it and that his actions were not contrary to the intentions of the founding fathers. ${ }^{102}$

Roosevelt understood the importance of creating an image. ${ }^{103}$ His election depended on that. He became the president following the assassination of president William McKinley in 1901. Knowing that no other presidents in his position were elected for a second term, he immediately started his effort on securing another term in office. "That became his prime objective, indeed his obsession," 104 Graubard pointed out. "He knew that only the electorate could renew his mandate, and his principal concern was to choose words and adopt policies calculated to win their favor... The president, represented as the champion of the little fellow against big business, became known as a

${ }^{102}$ William E. Leuchtenburg, The American President: From Teddy Roosevelt to Bill Clinton, 53. "Still, as H. W. Brands has written, 'Whatever readers made of the portents of Roosevelt's message, there was no mistaking the tone. This wasn't McKinley speaking; this was someone new, someone self-confidently assertive, someone with a far grander sense of the public purpose than anyone who had every held the presidency.'

Roosevelt, indeed, conveyed the impression that he intended to reign over a new political order. Like a chanticleer proclaiming the dawn, he asserted: 'When the Constitution was adopted, at the end of the eighteenth century, no human wisdom could foretell the sweeping changes ... which were to take place by the beginning of the twentieth century. At that time it was accepted as a matter of course that the several States were the proper authorities to regulate ... the comparatively insignificant and strictly localized corporate bodies of the day. The conditions are now wholly different and wholly different action is called for." (ibid., 31.)

103،"The president, with his oversized ego, seized upon every opportunity for selfpromotion. (In writing one of his books, Roosevelt, it was said, used "I" so many times that the publisher had to send a rush order to a foundry for more of that letter.) He made sure that he was front-page news by manipulating reporters through ploys such as releasing trial balloons and offthe-record revelations, and while his barber was lathering his face and sharpening his razor, he chatted garrulously with a half-dozen favored correspondents." (ibid., 30.)

${ }^{104}$ Stephen Graubard, Command of Office: How War, Secrecy, and Deception Transformed the Presidency from Theodore Roosevelt to George W. Bush, 84. 
trustbuster." ${ }^{\prime 05}$ He took care of impressing others, and he appreciated and practiced showmanship. ${ }^{106}$ The keynote of his character was his ambition. ${ }^{107}$ Hamilton Basso described him as "the first exponent of twentieth-century Barnumism in American politics."108 In addition to strong leadership and showmanship, if it was necessary to achieve his goals, Roosevelt used manipulation and political maneuvering. ${ }^{109}$ William Allen White stated, "His Machiavellian strain was grafted upon his sense of humor."110 Sometime his treatment of others was the result of disrespect and ignorance for opinions different than his. Graubard quotes from Biddle's book Mr. Justice Holmes, "'The truth was that [Theodore Roosevelt] could never forgive anyone who stood in his way." ${ }^{111}$ He divided the press in two groups: insiders and outsiders-those who supported

${ }^{105}$ Ibid., 85.

${ }^{106}$ Hamilton Basso, "Theodore Roosevelt: The American Progressive," in Theodore Roosevelt: A Profile, ed. Morton Keller (New York: Hill and Wang, 1967), 118-119.

${ }^{107}$ William Allen White, "Theodore Roosevelt," in Theodore Roosevelt: A Profile, 20.

${ }^{108}$ Hamilton Basso, "Theodore Roosevelt: The American Progressive," in Theodore Roosevelt: A Profile, 119.

109،'In 1903, overcoming fierce conservative opposition, he established a Department of Commerce and Labor that housed a Bureau of Corporations charged with investigating and exposing business malfeasance. His proposal for this bureau aroused such strident objections from stand-pat senators in his own party that it was doubtful that the measure would ever reach the floor. But at a time when it appeared to be doomed, Roosevelt announced to the press that John D. Rockefeller was masterminding the resistance. To substantiate his charge, he read out the language of what he said were Rockefeller's messages. He was fabricating. He had never seen any document, and he invented the words. But a Standard Oil official had turned out something like it, and Roosevelt created such a public outcry that Congress had no choice but to enact the law." (William E. Leuchtenburg, The American President: From Teddy Roosevelt to Bill Clinton, 36.)

${ }^{110}$ William Allen White, "Theodore Roosevelt," in Theodore Roosevelt: A Profile, 30.

${ }^{111}$ Stephen Graubard, Command of Office: How War, Secrecy, and Deception Transformed the Presidency from Theodore Roosevelt to George W. Bush, 85. 
him, and those who betrayed him. And he treated them accordingly. He fired a government employee for criticizing him, and he insisted that postal employees who promoted William Randolph Hearst be dismissed. He ordered shadowing and taping the phones of US senators without congressional permission, and asked newspaper publishers to reassign the journalists deemed critical of him. These reporters he branded the Ananias Club, invoking a biblical example of a liar. ${ }^{112}$ Obviously, he pushed for loyalty and considered opposition as animosity. ${ }^{113}$

At the same time, his strict adherence to moral values was probably the result of Puritan and Victorian ideals. White pointed out that "He was forever imaging himself as a man of the highest ideals... demonstrating to the youth of his country what such man can do in politics ... for the betterment of American life and the progress of the world." 114

While this depiction of president Roosevelt's leadership can suggest that his leadership practice can fit in the pattern for the analysis of the abuses of power this study proposed, because of the different nature of his leadership such an application would be inappropriate. Nevertheless, this leadership style is important because similarities and even similar terminology might suggest the influence of Roosevelt's leadership on the Adventist leaders. While future studies need to better investigate those influences, and some similarities could be accidental, nonetheless it can be observed that these influences

\section{Clinton, 50.}

${ }^{112}$ William E. Leuchtenburg, The American President: From Teddy Roosevelt to Bill

${ }^{113}$ Stephen Graubard, Command of Office: How War, Secrecy, and Deception Transformed the Presidency from Theodore Roosevelt to George W. Bush, 82.

${ }^{114}$ William Allen White, "Theodore Roosevelt," in Theodore Roosevelt: A Profile, 20. 
and similarities are more than coincidental and Kellogg and Daniells' leadership style resemble elements of Roosevelt's leadership. The analysis of the leadership of Daniells and Kellogg in the continuation of this study will present many similar character and behavioral traits to Roosevelt's. At the same time, it is hard to determine if the similarities are the result of commonly accepted ideas on leadership of that era, the influence of the president of the United States on Adventist leaders, or similarities in personalities. Nevertheless, those similarities can suggest a certain level of influence that American society and its political leaders had on Adventist church leaders.

\section{Summary}

By the turn of the twentieth century, the church had a serious problem with the excessive power used by very able, but authoritarian, leaders. This study analyses the abuses of two of them - J. H. Kellogg and A. G. Daniells.

The development of the church and its organization at the end of the nineteenth and beginning of the twentieth century had created a situation for developing abuses of power. The socio-political situation might contribute to this situation as well. At that time, the church recognized the mission of spreading the gospel as the primary reason for its existence. In order to fulfill that mission, the church needed to address abuses of power emerging from both the centralization of power and segmentation of the church in the independent auxiliary organizations. Consequently, the 1901 and 1903 sessions of the GC of Seventh-day Adventists attempted to face these challenges. Before discussing these attempts, this study will introduce the theological context useful for a better understanding of the events and detecting abuses of power. 


\section{The Seventh-day Adventist Doctrine of the Church}

An appropriate understanding of church organization and the doctrine of the church is beneficial for delineating abuses of power. That understanding discerns abuses of power related to the misuse of authority, misconduct of leadership, and ignoring the biblical principles of leadership, but it is useful for analyzing the other sorts of abuses of power as well.

Churches are differentiated by their unique set of beliefs - their doctrines. ${ }^{115}$ Like every other religious institution or denomination, Seventh-day Adventists have their particular doctrines. They regard a doctrine as "a common NT term that may denote the act of teaching ( $1 \mathrm{Ti} 4: 13 ; 5: 17)$ but more generally designates the content, or substance, of the information or idea transmitted." 116 Although Adventists officially reject ${ }^{117}$ any dogmatic approach to the questions of doctrine, the term doctrine for them describes the official teaching of the global Adventist church voted on by the GC of Seventh-day Adventists. ${ }^{118}$

${ }^{115}$ While in some denominations they are well defined, in others they are determined very loosely. According to the Encyclopedia Britannica, "Doctrine in theology (Latin doctrina; Greek didaskalia, didachē) is a generic term for the theoretical component of religious experience. It signifies the process of conceptualizing the primal-often experiential or intuitive - insights of the faith of a religious community in support of rationally understood belief. Doctrines seek to provide religion with intellectual systems for guidance in the processes of instruction, discipline, propaganda, and controversy." Encyclopedia Britannica, s.v. "Doctrine and Dogma, Religion," accessed Dec 01, 2016, https://www.britannica.com/topic/doctrine.

${ }^{116}$ Siegfried H. Horn, "Doctrine." in Seventh-day Adventist Bible Dictionary, ed. Don F. Neufeld (Washington, D.C.: Review and Herald, 1979), 291.

${ }^{117}$ Statement from introduction of Seventh-day Adventists believe: "We have not written this book to serve as a creed-a statement of beliefs set in theological concrete. Adventists have but one creed: 'The Bible and the Bible alone."' (Seventh-day Adventists Believe... A Biblical Expositions of 27 Fundamental Doctrines, vii.)

${ }^{118}$ See: ibid., iv. 
The current Adventist teaching or doctrine of the church is reflected in the 28 fundamental beliefs which are de facto the Adventist "confession of faith" - a collection of unifying beliefs voted by the delegates in GC sessions. Those beliefs are published with extended commentaries in the book Seventh-day Adventists Believe...: A Biblical Exposition of Fundamental Doctrines. ${ }^{119}$ The theological foundation of the doctrine of the church, both from that book and from other important Adventist sources, are presented in the following section.

\section{Theological Foundation of the Doctrine of the Church ${ }^{120}$}

Today Adventists view the church as the body of Christ, ${ }^{121}$ the worldwide and global community of believers united by God in community with those who answered the

\footnotetext{
${ }^{119}$ Ministerial Association General Conference of Seventh-day Adventists, Seventh-day Adventists Believe... A Biblical Exposition of Fundamental Doctrines (Silver Spring, MD: Ministerial Association, General Conference of Seventh-day Adventists, 2005). This book is published by the GC of the Seventh-day Adventist Church and is based on the statement of the 28 fundamental beliefs voted on during the sessions of the GC (1980 and 1995 with $28^{\text {th }}$ belief added in 2005) by representatives of the church from all over the world.

${ }^{120}$ The Seventh-day Adventist theologian Richard Rice explains the essential meaning of the church: "In the New Testament, the word 'church'... can refer to a group of people called together for a particular purpose; a community of Christian believers in a specific area; or to all of God's people, whenever and wherever they lived. It is never used in the Bible to refer to a building, and it never refers to one branch of Christianity opposed to another." (Richard Rice, Reign of God: An Introduction to Christian Theology from a Seventh-day Adventist Perspective, 210.)

${ }^{121}$ See: Reinder Bruinsma, The Body of Christ: A Biblical Understanding of the Church (Hagerstown, MD: Review and Herald 2009); Raoul Dederen, "The Church," in Handbook of Seventh-day Adventist Theology, ed. Raoul Dederen, Commentary Reference Series, vol. 12, (Hagerstown, MD: Review and Herald, 2000); Ministerial Association General Conference of Seventh-day Adventists, Seventh-day Adventists Believe... A Biblical Exposition of Fundamental Doctrines. "The body of Christ" was also used by Adventist pioneers. In her writings, Ellen White used the expression more than a hundred times.
} 
call to glorify God and fulfill God's intention of sharing the good news of salvation to all people. $^{122}$

The Old Testament “church” was created by God's call to a particular nation.

People became part of God's community of believers — the church — simply by being born into the chosen nation. Reinder Bruinsma points out that the Old Testament ideas of church include: election of individuals and families and ultimately nation (not for particular elevated statuses, but for tasks - missions of fulfilling God's plan), the covenant between God and "God's Holy People", and the concept of a remnant. ${ }^{123}$

In contrast, NT church members were called from all over the world, regardless of national, religious, or cultural background. Seventh-day Adventists Believe points to that difference: "Instead of a national church, it became a missionary church, existing to accomplish God's original plan, which was restated in the divine mandate of its founder, Jesus Christ: 'Make disciples of all nations' (Matt 28:19)."124 Bruinsma emphasizes that

\footnotetext{
${ }^{122}$ In the book Seventh-day Adventists Believe, the biblical view of the church is described as follows: "In the Scriptures the word church is a translation of the Greek ekklesia, which means 'a calling out.' This expression was commonly used of any assembly summoned by the practice of calling people to meet. The Septuagint, the Greek version of the Hebrew Old Testament popular in Jesus' time, used ekklesia to translate the Hebrew qahal, which stood for 'gathering,' 'assembly,' or 'congregation' (Deut. 9:10; 18:16; 1 Sam. 17:47; 1 Kings 8:14; 1 Chron. 13:2). This usage was broadened in the NT. Note how it uses the term church: (1) believers assembled for worship in a specific place (1 Cor. 11:18; 14:19, 28); (2) believers living in a certain locality (1 Cor. 16:1; Gal. 1:2; 1 Thess. 2:14); (3) a group of believers in the home of an individual (1 Cor. 16:19; Col. 4:15; Philemon 2); (4) a group of congregations in a given geographic area (Acts 9:31); (5) the whole body of believers throughout the world (Matt. 16:18; 1 Cor. 10:32; 12:28; cf. Eph. 4:11-16); (6) the whole faithful creation in heaven and on earth (Eph. 1:20-22; cf. Phil. 2:911)." (Ministerial Association General Conference of Seventh-day Adventists, Seventh-day Adventists Believe... A Biblical Exposition of Fundamental Doctrines, 165.) 30.

${ }^{123}$ Reinder Bruinsma, The Body of Christ: A Biblical Understanding of the Church, 22-

${ }^{124}$ Ministerial Association General Conference of Seventh-day Adventists, Seventh-day Adventists Believe... A Biblical Exposition of Fundamental Doctrines, 167.
} 
the church exists not because of human initiative but as the response to the divine call made by Jesus. $^{125}$

There are many metaphors used in the Bible to explain and describe the church and its role. Today Adventists use the following pictures as the most prominent metaphors: the church as a body, a temple, a bride, a family, "Jerusalem above," the pillar and foundation of truth, and an army - militant and triumphant. ${ }^{126}$ All of these images emphasize some important role and function of the church. They also express God's relationship with and intentions for the church. We have a more complete picture when we integrate each dimension of the church's identity.

Raoul Dederen enlarged the list of metaphors of the church by adding the pictures of the church as a vineyard, a fortress, a commonwealth, and a pillar of the truth. Then he concludes that in all the pictures the church exists as a theocratic reality which originates in and has its destiny in God. ${ }^{127}$ Additionally, the church is a Christocentric and charismatic community, it is God's chosen instrument of action, and has the responsibility of sharing the Gospel worldwide. All of that is reflected in the mission of the church to make disciples of all nations, instruct the believers, care for needy and suffering, to proclaim the gospel, the word to the world, following the guidance of and powered by the Holy Spirit. ${ }^{128}$

${ }^{125}$ Reinder Bruinsma, The Body of Christ: A Biblical Understanding of the Church, 39.

${ }^{126}$ Ministerial Association General Conference of Seventh-day Adventists, Seventh-day Adventists Believe... A Biblical Exposition of Fundamental Doctrines, 167-170. 549.

${ }^{127}$ Raoul Dederen, "The Church," in Handbook of Seventh-day Adventist Theology, 548-

${ }^{128}$ Ibid., 549-552. 
Membership in God's church is a privilege and an obligation at the same time. Today Adventists believe that membership in the church is founded on four principles:

1. In order to become a member of God's visible church, one has to reach and maintain the minimum standard for being part of the community of believers. "People who wish to become members of His church must accept Jesus Christ as Lord and Saviour, repent of their sins, and be baptized (Acts 2:36-41; cf. 4:10-12). They should have experienced the new birth and accepted Christ's commission to teach others to observe all things He commanded them (see Matt 28:20)." ${ }^{129}$ These standards are considered mandatory and create a distinction between believers and nonbelievers.

2. All members of the church are equal and relate to one another with respect and Christian love, regardless of cultural, racial, national, or any other difference. Equality is based on "Christ's declaration that 'you are all brethren' and 'he who is the greatest among you shall be your servant' (Matt 23:8, 11)." ${ }^{130}$ Equality also includes the responsibility of all members of the church to serve others according to the personal gifts and capabilities they have received from God.

3. Adventists believe in the priesthood of all believers. According to the words of the apostle Peter, "You also, like living stones, are being built into a spiritual house to be a holy priesthood, offering spiritual sacrifices acceptable to God through Jesus Christ" (1 Pet 2:9). That belief removes most differences between laity and clergy. "This priesthood makes no qualitative distinction between clergy and laity, although it leaves room for a

\footnotetext{
${ }^{129}$ Ministerial Association General Conference of Seventh-day Adventists, Seventh-day Adventists Believe... A Biblical Exposition of Fundamental Doctrines, 172.

${ }^{130}$ Ibid.
} 
difference in function between these roles." ${ }^{131}$ The varied roles indicate that the difference is on the level of dedicated time for the mission, the type of education received, and the source of one's wages.

4. Members of the church cherish two kinds of loyalty. They are loyal to the state and respect their government while at the same time remaining faithful to God. However, allegiance to God is considered greater than loyalty to the state. If those two loyalties are in conflict, obedience to God is primary for Christians because "we ought to obey God rather than men" (Acts 5:29).

Individual members of the church are united in the fulfillment of God's plan for sharing the knowledge of God and God's love and glory. This creates a unique relationship network which requires unity in diversity. ${ }^{132}$ Consequently, as with any other human institution, the church needs organization.

The Organization of the Church

The organized church has the following functions: worship and exhortation, Christian fellowship, instruction in the Scriptures, administering the divine ordinances, and worldwide proclamation of the gospel. ${ }^{133}$ According to the Adventist view of church

${ }^{131}$ Ibid., 173.

${ }^{132}$ Ellen White describes this particular relationship: "In our work we must consider the relation that each worker sustains to the other workers connected with the cause of God. We must remember that others as well as ourselves have a work to do in connection with this cause. We must not bar the mind against counsel. In our plans for the carrying forward of the work, our mind must blend with other minds." (Ellen White, Testimonies to Ministers And Gospel Workers: Selected From Special Testimonies to Ministers And Workers (Mountain View, CA: Pacific Press, 1962), 500.)

${ }^{133}$ Ministerial Association General Conference of Seventh-day Adventists, Seventh-day Adventists Believe... A Biblical Exposition of Fundamental Doctrines, 173-174. 
organization, every member of the church has a substantial role and significant position in the body of Christ. ${ }^{134}$ Thus, the biblical teaching of the priesthood of all believers has a deeper meaning and calls every member to active service to the church and community.

According to Adventist ecclesiology, the Bible recognizes two kinds of offices in the early Christian church: the elders and the deacons. ${ }^{135}$ The first office was meant to be mainly in charge of the spiritual needs of the church, and the second was primarily in charge of the material and temporal needs. This separation was not overly strict because it is evident that some elders of the church were involved in taking care of the members' temporal needs and some deacons participated in evangelistic work and preaching. The current church organization is much more complex. It includes many other duties and responsibilities based on spiritual gifts.

The Seventh-day Adventist Church Manual describes the current church organization, mainly defined in the 1901 and 1903 sessions of the GC, ${ }^{136}$ as an organization with four constituent levels - from the individual believer to the worldwide organization: 1. The local church is constituted from individual believers; 2 . The local conference or local field/mission is formed from churches in a state, province, or territory; 3 . The union conference or union mission is formed from conferences,

\footnotetext{
${ }^{134}$ See: ibid., 167; Raoul Dederen, "The Church," in Handbook of Seventh-day Adventist Theology, 547.

${ }^{135}$ See: Ministerial Association General Conference of Seventh-day Adventists, Seventhday Adventists Believe... A Biblical Exposition of Fundamental Doctrines, 176.

${ }^{136}$ Divisions were created later. In 1913 the GC approved the creation of a division conference in Europe. In 1918 the name division conference was changed to just division, the divisions were made an administrative division of the $\mathrm{GC}$, and the unions were made the constituent bodies of the church. At the 1922 GC this was included in the church's constitution and bylaws.
} 
missions, or fields; and 4. The GC is the largest unit of organization, includes all unions in all parts of the world, which are united in divisions with the administrative responsibility to designated geographical areas. ${ }^{137}$

These constituent levels of organization do not create the power structure of the church. The units are organized to disperse responsibility and make work more efficient and better adapted to the needs of each particular field. This structure was not designed to be a pyramid of authority but rather as a way of designating responsibility. Dederen explains that basic principles of the church' government are: "Christ is the head of the church," "His will, as revealed in the written Word, is the ultimate standard," and Christ did not transfer his authority to the leaders but rather they received delegated, that is, derived authority (through God's call and chosen by the congregation). ${ }^{138}$ Based on that Dederen rejects the biblical basis for any authoritative organizational structure and suggests that the appropriate form of church organization is a representative model based on the priesthood of all believers and gifts received from the Spirit. ${ }^{139}$

Consequently, Adventists recognize the following principles of church government: Christ is the head of the church, Christ is the source of all church authority, the Scriptures carry Christ's authority, and Christ exercises His authority through the church and its especially appointed servants. ${ }^{140}$ The officers of the Adventist Church are

${ }^{137}$ General Conference of Seventh-day Adventists, Seventh-day Adventist Church Manual (Silver Springs, MD: General Conference of the Seventh-day Adventist Church, 2003), 26.

${ }^{138}$ Raoul Dederen, "The Church," in Handbook of Seventh-day Adventist Theology, 554.

${ }^{139}$ Ibid.

${ }^{140}$ Ministerial Association General Conference of Seventh-day Adventists, Seventh-day Adventists Believe... A Biblical Exposition of Fundamental Doctrines, 175-176. 
elected by their congregations, and even though they represent their churches, their authority comes from God, who established the church and led to its organization.

The headship position of Christ was recently affirmed by a statement of the faculty of the Andrews University Seventh-day Adventist Theological Seminary:

Christ is the only Head of the Church (Eph 1:22; 5:23; Col 1:18). Therefore, while there exists legitimate leadership in the Church, no other human being may rightfully claim a headship role in the Church. As Head of the Church, Christ provides the ultimate manifestation of God's love (Eph 5:23,25), demonstrating and vindicating God's moral government of love (Rom 3:4, 25-26 5:8), and thus defeating the counterfeit government of the usurping "ruler of this world" (John 12:31; 16:11; cf. DA 758; $2 T 2: 211) .{ }^{141}$

This statement correctly recognizes Christ's rightful leadership position. Nevertheless, the rejection of a classical hierarchical structure in the form of a pyramid, such as one in the Roman Catholic church (or one labeled kingly power), can be interpreted as a rejection of any hierarchy. This would diminish all leadership authority, responsibility, and the legitimate right of Christian leaders to exercise their power inside of the boundaries of their submission to the headship of Christ.

While the Bible endorses the equality of all humans, the creation of any organization produces different functions for the various members of that organization. So that these functions may be productive and bring the adequate results, they are bound to responsibilities. Different levels of responsibility and authority lead to an organization with a hierarchical structure and some kind of governance. ${ }^{142}$ This hierarchical structure

141 "On the Unique Headship of Christ in the Church," Andrews University Seventh-day Adventist Theological Seminary, accessed 1/06/2016. https://www.andrews.edu/sem/9-19-14updated_web_version-unique_headship_of_christ_final.pdf.

${ }^{142}$ Bruinsma pointed out the fact that Christ is the head are under his authority. Different role of the part of the body implies different importance and responsibility, based on spiritual gifts. (Reinder Bruinsma, The Body of Christ: A Biblical Understanding of the Church, 52-54.) 
does not diminish the importance of the contribution of all the members of that organization.

That can be further explained with the biblical image of the church as a body. The body has different parts, and all parts are important. The suffering of one part affects the whole body. At the same time, these parts are of varying importance for the functionality of the entire body. While Christ is the head of that body, the heart is more important than the toe for the functionality of the body. Paul described the structure of the church: "Now you are the body of Christ, and each one of you is a part of it. And God has placed in the church first of all apostles, second prophets, third teachers, then miracles, then gifts of healing, of helping, of guidance, and of different kinds of tongues. Are all apostles? Are all prophets? Are all teachers? Do all work miracles? Do all have gifts of healing? Do all speak in tongues? Do all interpret?" (1Cor 12:27-30 New International Version [NIV]) Although all parts are essential for the well-being of the body, there is a hierarchy of the importance of a particular function of one part compared to the other. ${ }^{143}$

The church does not have a flat organizational structure. However, the hierarchy in the church setting does not imply rulership or headship. Ruling over brethren belongs

Hierarchy in such organization is an inevitable consequence. Dederen also emphasized different responsibilities of members of the church: "There is one body, with members having different functions, yet all equally honorable and necessary to the efficient working of the body as a whole." (Raoul Dederen, "The Church," in Handbook of Seventh-day Adventist Theology, 547.) Then he used another biblical picture to put Christ above anybody else: "As the head Christ is the source and the locus of authority that the whole body is to obey (Col. 2:10)." (ibid.)

${ }^{143}$ According to Bruinsma, some parts pay more prominent role than others, depending on spiritual gifts, all parts have its own unique function, and hurting any part affects the whole body. Christ is the head of that body, and recognizing his authority prevents from overstating the importance of any other church office. (Reinder Bruinsma, The Body of Christ: A Biblical Understanding of the Church, 53-54.) See also: Richard Rice, Reign of God: An Introduction to Christian Theology from a Seventh-day Adventist Perspective, 214. 
to the realm of the abuse of power. E. G. White clearly emphasizes that "no man has been made a master, to rule the mind and conscience of a fellow-being. Let us be very careful how we deal with God's blood-bought heritage. To no man has been appointed the work of being a ruler over his fellow men."144 The hierarchy in the church is not a pyramid in which those with higher rank are given more power. It is one with all members submitted to the headship of the Christ. That hierarchy is supposed to be a functional hierarchy based on the specific duties and roles in the organization and the authority derived from them. Ideally, it rests on the spiritual gifts received by the Holy Spirit and recognized by the church (see Rom 12:4-8).

Unfortunately, it seems that humans find it very hard to separate functional hierarchy from rulership. Being in a leadership position brings respect, honor, and authority. Titles of a particular leadership position imply authority and power, but also hierarchy: pastor, elder, deacon, president, chair, secretary, teacher, professor, board member. To cope with the problem the church was organized in the structure in which power is given to committees instead of individuals.

Stanley E. Patterson notices the discrepancy between the theoretical model and practice in the contemporary Seventh-day Adventist Church. ${ }^{145}$ Two of the most likely reasons for that deviation are a willingness of the church members to transfer the authority and responsibility to "professionals" and the temptation of leaders to feel $9-10$.

${ }^{144}$ Ellen White, "Individual Responsibility \& Christian Unity", 1907, Manuscript 29, 1907

\footnotetext{
${ }^{145}$ See: Stanley E. Patterson, "The Place of Authority in the Organizational Structure of the Seventh-day Adventist Church," Potomac Conference of Seventh-day Adventist Church, accessed January 16, 2016, 2016. http://www.pcsda.org/wp-content/uploads/2014/10/The-Placeof-Authority-in-the-SDA-Organizational-Structure1.pdf.
} 
responsible for governing rather than being stewards and to lead by example. The second reason is intensified by the voluntary surrender of people's authority and their expectation that the leader in charge takes all responsibility. The pattern can be observed in the way members of the church treat their leader. The "higher" office they hold, the more honor and respect they receive. While some Christian leaders abuse their power and impose headship on their followers, too often and usually unconsciously, the followers affirm and imply the headship of their Christian leaders.

The purpose of the church organization is to help people to fulfill their mission in the most efficient way and to prevent or minimize the occurrence of power abuses. While the reorganization of the church attempted to shift power from the individuals to the entire body of the church, and the autocratic model of church governance and the abuses of power in the church leadership were the reason for the reorganization of the church in 1901 and 1903, according to Patterson, the church in today's practice is potentially moving back toward "an episcopal model of ecclesiastical governance."146

\section{Historical Context of the Development of the Church Organization}

While the ideals of Christian leadership were always the same, leaders did not understand them in the same way. Therefore, a historical dimension must be included in an assessment of the leadership practices of the Church's pioneers. In addition, there is also the need to understand (or at least to attempt to understand) the historical and

\footnotetext{
${ }^{146 "}$ The representative model of ecclesiastical governance and the organizational structure that supports and administers it in the Seventh-day Adventist Church is being challenged by leadership and management practices within the church that are at best diminishing the effectiveness of the representative model and at worst are moving the denomination toward an episcopal model of ecclesiastical governance." (ibid.)
} 
ideological background of the leaders of that era. Thus a review of two important subjects about church organization at the time of the "kingly power" issue - the relationship between authority and leadership and the best model on which to build the Church's organization - would enhance our ability to assess the leadership of the church at that time.

In an early Adventist book on church organization entitled The Church: Its Organization, Ordinances, and Discipline, ${ }^{147}$ published in 1886, J. H. Waggoner proposed that church organization is the result of a need for order in the church. ${ }^{148}$ This resulting organization has authority over the membership - it has the power and duty of discipline. ${ }^{149}$ All quotations from the Scripture in Waggoner's book were from the King James Version and consequently the leaders in the church are "officers" and "rulers." 150 It seems that, for Waggoner (and the pioneers as well), "to lead" and "to rule" were synonyms. He noted that the leaders' (rulers) authority was confirmed by ordination. Furthermore, he emphasized several matters, specifically respect for church organization

${ }^{147}$ J. H. Waggoner, The Church: Its Organization, Ordinances, and Discipline (Oakland, CA: Pacific Press, 1886).

${ }^{148}$ The idea of the need for order can be traced to the call for the "gospel order" found in the writings of James and Ellen White, as early as 1850s. Denis Kaiser in his article Setting Apart for the Ministry: Theory and Practice in Seventh-day Adventism (1850-1920) quoted more than twenty document from early 1850 s with call to adhere to the "gospel order" - "principle illustrated in the order in heaven, among Christ's disciples, and in the early NT church." (Denis Kaiser, "Setting Apart for the Ministry: Theory and Practice in Seventh-day Adventism (18501920)," Andrews University Seminary Studies Vol. 51, no. 2 (2013): 178, http://digitalcommons.andrews.edu/auss/vol51/iss2/2.)

${ }^{149}$ J. H. Waggoner, The Church: Its Organization, Ordinances, and Discipline, 6-7.

${ }^{150}$ The word $\dot{\eta} \gamma \varepsilon \dot{c} \mathrm{\mu} \alpha \mathrm{l}$ - hegeomai in Hebrews 13 is translated as "rule/rulers" in the King James translation, while other translations use "lead/leaders" instead, the $\pi \rho 0 \hat{\sigma} \sigma \tau \eta \mu \mathrm{t}$ proistemi in 1. Timothy 5:17 and Roman 12:8 is translated with "rule" in the same translation while other use "manage." 
and the church's respective offices, need of a unified faith, and agreement on principles. Still, the document did not ignore individual freedom and placed the authority of the body above the authority of leaders. ${ }^{151}$ Apparently, a strong emphasis on the need for order and the authority of the organization and its offices was the result of an intense fight over church organization, fanaticism of some believers, and animosity toward any form of organization. Strong organization was perceived as necessary to prevent individual abuses and deviations from biblical truth.

Twenty years later in another work about church organization titled The Church: Its Organization, Order and Discipline, ${ }^{152} \mathrm{~J} . \mathrm{N}$. Loughborough proposed very similar ideas on leadership. He incorporated an even stronger emphasis on rulership of leaders, but also added that the rulers have to rule in an appropriate Christian way: according to Jesus' example of selfless love. Leading, governing and ruling are used again as synonyms. ${ }^{153}$ Additionally, he made a very strong case for following Moses' style of leadership - his generalship. ${ }^{154}$ Based on his understanding of Scripture and the Spirit of Prophecy, Loughborough proposed a very authoritarian leadership with the "love of the truth the safeguard" "155 to prevent abuses of rulership. His book became the basis for future church manuals. It is interesting that Loughborough modified his statement on the

${ }^{151}$ J. H. Waggoner, The Church: Its Organization, Ordinances, and Discipline.

${ }^{152}$ J. N. Loughborough, The Church: Its Organization, Order and Discipline (Washington D. C.: Review and Herald, 1907).

${ }^{153}$ Ibid., 40-43.

${ }^{154}$ Ibid., 63.

${ }^{155}$ Ibid., 75. 
rejection of creed, which he made in 1861, and altered it to allow such an authoritarian church structure. ${ }^{156}$ It appears that Loughborough's work reflected two struggles, namely the struggle among leaders themselves and the struggle over leadership in the church at the beginning of the twentieth century. During this time the church lost prominent leaders. Loughborough's work can also be seen as a reaction to the group of leaders that proposed a different type of organizational structure and leadership. For example, A. T. Jones in his sermon Church Organization ${ }^{157}$ from the General Session of 1901, proposed a leadership based on the equality of all members, in which God is the authority rather than position. For Jones Jesus had authority but no place or position. He states, "God has never given any man in his church authority to exercise authority... The princes of God [God's people] having true authority, never exercise authority; being the authority of the

156“"We call the churches Babylon, not because they covenant together to obey God. . . . The first step in apostasy is to get up a creed, telling us what we shall believe. The second is to make that creed a test of fellowship. The third is to try members by that creed. The fourth to denounce as heretics those who do not believe that creed. And, fifth, to commence persecution against such." (James White, "Doings of the Battle Creek Conference, Acts 5:16, 1861," The Review and Herald vol. 18, no. 19 (8 October 1861).) "The Five Steps of Apostasy. . . 1. Forming a creed, expressing their faith in man-made phrases instead of adhering to the word of the Lord. 2. Making that man-made creed a test of fellowship, and denouncing all as heretics who would not assent to the exact wording of their creeds. 3. Making the creed a rule by which all heretics must be tried. Many were thus declared sinners whose faith was more in harmony with the direct statements of the Bible than that of those who decreed against them. 4. Constituting themselves a tribunal for the trial of heretics, and excluding from their fellowship all who would not assent to their creeds. Not content to debar such from church privileges in this world, they declared them subjects for the lake of fire. 5. Having thus kindled a hatred in their own hearts against all who did not conform to their creeds, they next invoked and obtained the aid of the civil power to torture, and kill with sword, with hunger, with flame, and with beasts of the earth, those whom they had declared unfit to remain in the world." (J. N. Loughborough, The Church: Its Organization, Order and Discipline, 76-77.)

${ }^{157}$ A. T. Jones, Church Organization, Words of Truth (Battle Creek, MI: Review and Herald, 1901). 
truth of God, it exercises itself." ${ }^{158}$ Consequently, there is no dominion among God's people. ${ }^{159}$ Authority is in the truth and in the church's head, which is Christ. ${ }^{160}$

It appears that the majority of church leaders in the first 50 years of church organization accepted an authoritarian leadership style in administration and ecclesiology, but their views and practices were challenged by those who proposed that other biblical principles must be included in church organization. Although contemporary theology does not employ entirely different arguments, the emphasis has shifted toward a much less authoritarian view of church organization. Nevertheless, that shift was already in motion during the time of the pioneers.

Based on two different views on the authority of the church, an argument ensued over the ideal leadership model for the church. The most common leadership model proposed by A.G. Daniells and his supporters was the Mosaic model of organization. ${ }^{161}$ In $1892 \mathrm{~S}$. H. Haskell used the Mosaic scheme to illustrate the ideal church structure that should be followed in its organization. While later Loughborough used it in the same way, for Daniells and Spicer the Mosaic model gave theological justification for church organization. Almost every apologetic for church organization after 1901 started with the Mosaic plan, especially between the years 1905 and 1909. In 1907 Daniells suggested

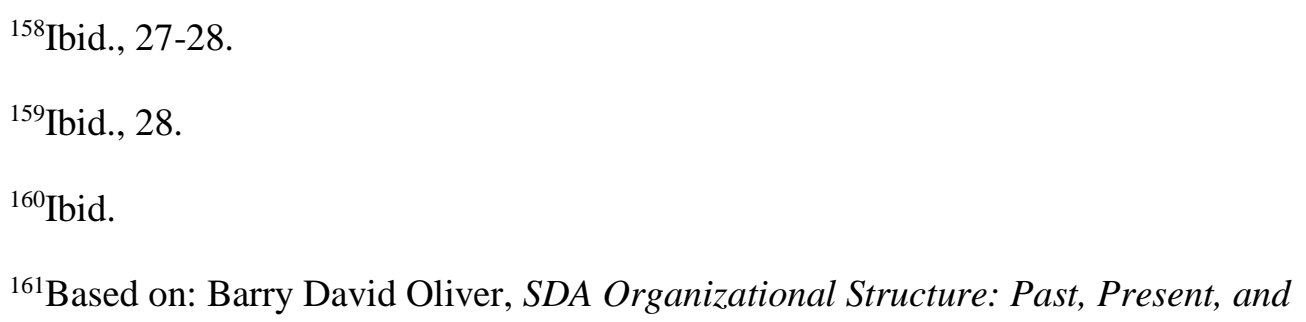
Future. 
that the Mosaic organizational structure is "the most perfect organization applicable to human society." 162

Although contemporary Seventh-day Adventist theologians do not employ the same argument, ${ }^{163}$ the Mosaic argument (probably based on the legacy of Loughborough's work) is used in the current Seventh-day Adventist Church Manual. ${ }^{164}$ This manual, under the subsection Biblical Basis for Organization, suggestes that God provided "an impressive system of organization" based on God as the center of authority and Moses as his visible representative. This document quotes E. G. White, who depicted Moses as a divinely appointed leader to administer laws in God's name. Under Moses were the seventy elected leaders, and then priests, followed by chiefs, who ruled over the tribes. Indirectly, this model proposes that the best church organization is a pyramid of hierarchy that stretches from God to his people.

It is not surprising that some of the pioneers objected to this model. Jones asserted that this model was applicable for the Old Testament times and not for the Christian church. ${ }^{165}$ He presented the strongest opposition to the idea in his appeal to the GC in 1909, when he suggested that, "the denomination is openly and positively committed

${ }^{162}$ Quoted from: ibid., 261.

${ }^{163}$ Raoul Dederen, "The Church," in Handbook of Seventh-day Adventist Theology; Ministerial Association General Conference of Seventh-day Adventists, Seventh-day Adventists Believe... A Biblical Exposition of Fundamental Doctrines; Richard Rice, Reign of God: An Introduction to Christian Theology from a Seventh-day Adventist Perspective.

${ }^{164}$ Seventh-day Adventist Church Manual, 21.

${ }^{165}$ Barry David Oliver, SDA Organizational Structure: Past, Present, and Future, 262. 
professedly to the Mosaic order but in fact to the first steps of the papal order." ${ }^{166}$ It appears that Daniells could not understand this argument because of his firm belief, expresed in his letter to L. R. Conradi, that "every board must have a chairman or president, that will be the recognized head." ${ }^{167}$ Oliver emphasized that in the same letter, Daniells claimed that "the church had no visible head other than Christ." 168 While Jones failed to recognize that the church is not only a theological entity, but also has a sociological dimension with a need for organizational structure, the practical and pragmatic concerns of Daniells were the reasons why it seems that he did not pay more attention to the spiritual dimension of the church. ${ }^{169}$

When the Mosaic model is used as the theological reasoning behind church organization, there is an inherent danger of creating a hierarchy that is contrary to Jesus' teaching. This in turn gives "kingly power" to the leaders and committees of the church. A comparison of the leadership structure of the Israelites in the book of Exodus with the leadership structure of the modern church can lead to two opposing emphases. On the one hand, it can emphasize the need for sharing the responsibility of leadership among God's people. On the other hand, it can stress the authority of the leaders and leadership structure, incorporating a pyramidic church organization in which each ascending level accumulates more power. The second emphasis is dangerous because today's church organization differs from the one in the time of Moses in one particular point: Moses was

${ }^{166}$ Alonzo T. Jones, An Appeal for Evangelical Christianity (Battle Creek, MI: 1909), 49.

${ }^{167}$ Quoted from: Barry David Oliver, SDA Organizational Structure: Past, Present, and Future, 264.

${ }^{168}$ Ibid.

${ }^{169}$ Ibid., 263. 
directly chosen by God (and even against his own preferences and wishes). In contrast, today's leaders are elected by people and boards. While in theory church organization deals with ecclesiastical and administrative authority and not political authority, the election process is not immune from human manipulation and politics. Even with its spiritual dimension, with prayers to invite God's guidance, it is not comparable to God's direct election.

Using the Mosaic model of leadership as an example of an ideal leadership model is additionally challenged by the nature of Moses' leadership. He not only had authority as a leader, but he also had authority as a prophet of God. He was the personal messenger of the Lord. God reacted very firmly when Moses' prophetic authority (and consequently God's kingly authority) was challenged. Even Moses did not enter the Promised Land when he inappropriately mixed his prophetic authority with his leadership authority. In the Seventh-day Adventist church, prophetic authority was separated from leadership authority from the beginning. The church leaders held only leadership authority. Therefore, using the Mosaic model in the church in any other way except as an example of dispersion of power and responsibility might introduce all kinds of abuses of power. Although one's particular view on appropriate Christian leadership determines how one perceives the leadership of the pioneers, an abuse of power is determined by the biblical principles, not by personal view and perception. Many injustices are legal, but that does not make them right. And even if they are the result of a misunderstanding or lack of knowledge, they are still not right. A lack of proper understanding might be considered a mitigating factor but it does not justify the occurrence of an abuse of power. 
Consequently, some abuses of power are the result of a misunderstanding of the leadership position and its responsibilities. If a leader and his subordinates assume that leadership in the church also means rulership, the authoritarian method will be employed and used. In this case, a neutral observer could see many activities as abuses of power, while the leader in charge and his followers might consider his actions and behavior as appropriate; they might not be aware of any abuse of power. We must recognize that many cases of abuse observed during the time of Kellogg and Daniells were not perceived as an abuse of power neither by them nor by their subordinates. Nevertheless, as we already pointed out, Ellen White challenged the leadership of both leaders, reproving them for using "kingly power." Their abuses of power noted in the fourth chapter are not determined based on their knowledge or understanding but on their actions and behavior. While understanding the background of their position can make us more sympathetic and objective, the objective of this study is to learn moral lessons from their example.

\section{Summary}

The two most defining elements of every church denomination are the mission and organization of that church. The first determines where the church is heading, and the second determines how the church will get there. The struggle in the Seventh-day Adventist church at the beginning of the twentieth century created the framework for an enrichment of theology and an improvement of the church organization. It warned about the potential abuse of power among leaders and the importance of the church being dependent on God's authority. 
Thus, the appeal for no kingly power was asking for collective, corporate leadership, in order to counteract human weakness and tendency to rule over others. Ellen White very strongly stated that "no man's judgment should be surrendered to the judgment of any other one man. Never should the mind of one man or the minds of a few men be regarded as sufficient in wisdom and power to control the work and to say what plans shall be followed." ${ }^{170}$ But then she appealed to individuals to respect the corporate authority of the church as the body of Christ.

Ideally, the organizational model of the Seventh-day Adventist Church is based on the authority of the members of the church, which is by representation shared in the authority of the global church. Leaders are not owners but stewards of authority, limited by the scope of their mandate and assignment. Together with their base - the body of the church - they submit to the headship of Christ. The 1901 and 1903 sessions of the GC of the Adventist Church were an attempt to organize the church to reflect those ideals and fulfill its mission.

\section{Response of the Church to the Issue of Kingly Power: Reorganization of the Church During the 1901 and 1903 Sessions of the GC}

In the last decades of the nineteenth century, church leaders and members were aware that the organizational structure from the early 1860 s was no longer successfully fulfilling its purpose. Oliver pointed out that during the 1890s it had become apparent that to continue to grow, the church organization needed adjustments. ${ }^{171}$ At that time the

\footnotetext{
${ }^{170}$ Ellen White, Testimonies for the Church, vol. 9 (Nampa, ID: Pacific Press, 2002), 260.

${ }^{171}$ Barry David Oliver, SDA Organizational Structure: Past, Present, and Future, 218.
} 
question from the 1860s was not about the need for organization, but rather what form of organization the church needed. Oliver asserted that Adventists of that time did not have consensus on a distinctive ecclesiology. ${ }^{172}$ They rather concentrated on other doctrines which gave them reasons for existence as a denomination. As the result, leaders had different views and used different theological arguments to support the reorganization of the church structure. In that situation, two main viewpoints emerged. The first one was represented by A. T. Jones, E J. Waggoner, D. J. Paulson, Percy T. Megan and, for some time, W. W. Prescott. A. T. Jones with his associates emphasized that biblical principles of the headship of Christ, the priesthood of all believers, the church as the body of Christ, salvation by faith and spiritual gifts have to determine the form of the church's organization. ${ }^{173}$ Consequently, their emphasis was on a personal relationship with Christ and the local nature of the church. They opposed any terminology which diminished the headship of Christ, such as the term "president."

The second viewpoint was of A. G. Daniells and his allies W. C. White and W. A. Spicer. They emphasized that the church is not only local but also universal in nature and that universal unity of the church had priority over individuality. They neither rejected nor denied the arguments of the other side, but rather challenged the possibility of organizing the church for its mission based on the theological concepts proposed by the other side. Those two emphases affected the reorganization of the church and the struggle between leaders.

${ }^{172}$ Ibid., 219.

${ }^{173}$ See: George Knight, Organizing to Beat the Devil: The Development of Adventist Church Structure, 87; Barry David Oliver, SDA Organizational Structure: Past, Present, and Future, 220. 
While the leaders of the church attempted to figure out the best organizational model, some practical development preceded the reorganization. In 1888 at the GC session, there was a first attempt at the decentralization of the church by dividing the church in the United States and Canada into the four districts. The following year the church was redistricted into six districts. In the early 1890 s, an experiment of reorganization in South Africa placed auxiliary organizations in South Africa under the executive control of the South African Conference. ${ }^{174}$ Under the pressure of A. T. Jones' arguments, in 1897 the church was divided into three grand divisions - the United States and British North America, Europe, and Australasia. ${ }^{175}$ Each of them became known as a "General Conference" and had their own president. ${ }^{176}$ Oliver pointed out that the president in North America held priority regarding the world church. ${ }^{177}$

In 1894 the Australian Union was organized in what became the first union conference in the Seventh-day Adventist church. While Daniells drew from the Australian experience during the reorganization of the church in 1901, he always credited W. C. White for that development. In 1898, Adventists in Europe initiated the organization of a union conference as a response to the call for decentralization. ${ }^{178}$ 73-81.

${ }^{174}$ See: Barry David Oliver, SDA Organizational Structure: Past, Present, and Future,

${ }^{175}$ See: George R. Knight, Organizing to Beat the Devil: The Development of Adventist Church Structure, 89-90.

${ }^{176}$ Richard Schwarz and Floyd Greenleaf, Light Bearers: A History of the Seventh-day Adventist Church, 252-253.

${ }^{177}$ Barry David Oliver, SDA Organizational Structure: Past, Present, and Future, 144. ${ }^{178}$ Ibid. 
Those processes during the 1890 s were just partial steps; they were not implemented according to the decisions of the GC sessions, and in the periods between sessions, some of them were reverted or changed. Interestingly enough, although attempts were focused on decentralization of the church, the beginning of the twentieth century found the church more centralized than ever. At the same time, these small steps were influences which, in a way, prepared the church for reorganization. Knight points out that "we should view reorganization as the process that climaxed in 1901 and underwent refinement in 1903."179

The Main Issue at the 1901 Session of the GC

The 1901 session started before its official beginning. The day before opening the thirty-fourth session of the GC, the leaders of the church were gathered in the Battle Creek College library to discuss the organizational needs of the church. Ellen White was invited to that meeting, and even though she did not prepare a speech, she was called to address the gathered leaders. In her speech, she expressed three areas of concern:

(1) the "state of things" in the conferences - leaders did not understand the nature of their responsibility to the church and their influence in the church, (2) the numerical growth and the geographical extensions of the missionary endeavor of the church, and (3) the centralization of administrative control in "one mind or two minds or three minds or four minds, or few minds." 180

In response to those concerns, she delivered her suggestions and called for change. These changes included the following: the session sub-committees should be composed of representatives of all church organizations; they should follow the

${ }^{179}$ George Knight, Organizing to Beat the Devil: The Development of Adventist Church Structure, 103.

${ }^{180}$ Barry David Oliver, SDA Organizational Structure: Past, Present and Future, 164. 
leadership of the Holy Spirit; church activities and responsibilities should be spread and shared among all members and leaders; leaders should be people of integrity and principles, who have experience in practical field work; and no leader should have the right to exercise excessive power, nor should any committee have the right to control work in a totalitarian manner, because the work was to be controlled by the Holy Spirit. $^{181}$

In her talk immediately after the opening of the 1901 session, Ellen White pointed out that the church was already late with reorganization: "I feel a special interest in the movements and decisions that shall be made at this Conference regarding the things that should have been done years ago, and especially ten years ago, when we were assembled in Conference, and the Spirit and power of God came into our meeting, testifying that God was ready to work for this people if they would come into working order." ${ }^{182}$ This time, the church did not miss the opportunity, and changes began.

The activities of the GC session which followed were a continuation of the meeting in the library. A. G. Daniells, together with the other leaders, supported Ellen White's views, and the 1901 GC session became focused on decentralization of the church leadership. The idea of reorganization was also supported by Jones' sermon, in which he called "for reorganization that dealt with individual renewal and dedication to Christ while he neglected those parts that touched on the more global factors of an

${ }^{181}$ Ellen White, A Call to Reconsecrate, Reorganize, and Advance, 1993, 1901, Manuscript Releases, vol. 13, Silver Spring, MD.

${ }^{182}$ Ellen White, "Opening Remarks," The General Conference Bulletin, Thirty-fourth Session, April 3, 1901, 23. 
organization." 183 Jones said that "a reorganization of the GC calls for a reorganization of each individual Seventh-day Adventist throughout the world." 184

In SDA Organizational Structure: Past, Present, and Future, Oliver suggested that the theological principles of both theological viewpoints on the reorganization of the church were implemented. For Jones and his allies, "Self-government was their first principle." From that, they deducted the others: "Distributed authority and mutual rule, independence, individuality, and self-support." 185 According to Daniells, the "first principle of reorganization was decentralization.... Other principles of reorganization were representation, broad-based authority, simplicity, and adaptability." ${ }^{186}$ While measures taken exhibit more of Daniells' theological principles, an influence of Jones' arguments in them is apparent. Both sides were satisfied with the measures adopted during the 1901 session.

\section{Measures Taken During the 1901 Session}

The first measure was the organization of a larger committee, the Committee on Counsel, which was to give recommendations for reorganization. This committee was based on Daniells' suggestion, and under his "direction the seventy-five-member committee divided into subcommittees to tackle narrower problems of organization."187

\footnotetext{
Structure, 106.

${ }^{184}$ Alonzo T. Jones, "Evening Sermon," The General Conference Bulletin, Thirty-fourth Session, April 4, 1901, 37-42.

${ }^{185}$ Barry David Oliver, SDA Organizational Structure: Past, Present and Future, 321.

${ }^{186}$ Ibid., 321. 322.

${ }^{187}$ Richard Schwarz and Floyd Greenleaf, Light Bearers: A History of the Seventh-day Adventist Church, 256.
}

${ }^{183}$ George Knight, Organizing to Beat the Devil: The Development of Adventist Church 
The Committee on Counsel proposed the following changes, which were then accepted by the delegates.

The first change was the recommendation that the Union Conferences take the place of the state conferences as the building blocks of the GC, in order to optimize organizational functionality by dividing the GC into smaller organization units. At the same time, this simplified the organization "by making the various branches of work, such as the Sabbath school, educational, publishing, and others, departments of the conference." ${ }^{188}$ Ellen White endorsed these changes. "Conferences must be organized in different localities, and it will be for the health of different conferences to have it thus.... We want to understand that there are no gods in our Conference. There are to be no kings here, and no king in any Conference that is formed." 189

The second change was the creation of an expanded GC Executive Committee of twenty-five members. They were chosen by this formula: six chosen by the Medical and Benevolent Association, and nineteen chosen by the session delegates. Included in these nineteen would be Union Conference presidents, and the presidents of the newly formed unions would join the Executive Committee. ${ }^{190}$

The third change was to place the functions of the auxiliary organizations under the control of the GC by making them departments of the GC. New departments

${ }^{188}$ Gilbert Jorgensen, “An Investigation of the Administrative Reorganization of the General Conference of Seventh-day Adventists as Planned and Carried Out In the General Conferences of 1901 and 1903" (MA Seventh-day Adventist Theological Seminary, Washington D.C., 1949), 31.

${ }^{189}$ Ellen White, "General Conference Proceedings," The General Conference Bulletin, Thirty-fourth Session, April 5, 1901, 68-69.

${ }^{190}$ Richard and Greenleaf Schwarz, Floyd, Light Bearers: A History of the Seventh-Day Adventist Church, Rev. ed. (Nampa, ID: Pacific Press Publishing Association, 2000), 256. 
controlled by the Executive Committee were the Foreign Mission Board, Sabbath School Association, Religious Liberty Association, and the publishing committee, which took control over the Tract and Missionary Society. The educational programs had already been under the jurisdiction of the GC since 1887, but responsibility for certain local educational institutions was transferred to the Union Conferences.

There were two main reasons for these changes: to make the organization of the church more efficient and to counteract the threat of kingly power and centralization of the church and her activities in one place. Gilbert Jorgensen points to the constitution voted by the $1901 \mathrm{GC}$ session as an explanation for how the church tried to manage the problem of excessive kingly power: "In an attempt to do away with one-man control of the GC, the constitution provided for a chairman of the Executive Committee instead of a President of the GC. This, however, created another problem, for it left no official head of the denomination to sign legal documents." 191

Knight explains, "The major changes involved both centralization and decentralization. On the one hand, they dispersed presidential administrative authority.... But on the other hand, the official church had gained more direct power over its various branches." ${ }^{" 192}$ The reorganization of church centralized control over the various branches of the church, while at the same time it decentralized the executive power of its leaders. The church as institution had more control over resources and their distribution, but the leaders were supposed to function as the chairman of the bigger boards instead of as

\footnotetext{
${ }^{191}$ Gilbert Jorgensen, "An Investigation of the Administrative Reorganization of the General Conference of Seventh-day Adventists as Planned and Carried Out In the General Conferences of 1901 and 1903," 48.

${ }^{192}$ George Knight, Organizing to Beat the Devil: The Development of Adventist Church Structure, 109.
} 
executive decision makers. In 1901, the office of the president of the GC was replaced with the chair of the Executive Committee. Yet that complex solution to a multifaceted problem had to pass the test of implementation in everyday practice. That practice was shaped by the official marginalization of the power of the leaders and, at the same time, the struggle of the leaders for power and control of the denomination.

\section{The Period between the Two Sessions}

The period between the 1901 and 1903 sessions was marked by conflict in the leadership structures of the church. Ellen White endorsed the conclusions of the session in 1901, but she was deeply disappointed with the practical results. According to her, nothing was applied in practice. ${ }^{193}$ The conflict was the natural outcome of the discrepancy between the measures taken and their practical application. It was also a continuation of the power struggle which the session in 1901 had attempted to resolve.

Knight pointed out that in 1901, J. H. Kellogg was the one who made the motion to appoint A. G. Daniells to be the chairman of the Executive Committee of the GC, and A. T. Jones seconded it. ${ }^{194}$ One of the goals of the 1901 reorganization was building a better relationship between different branches of the church, especially with the medical and health branches. It appeared that everything was moving in the right direction.

193، The result of the last GC has been the greatest, the most terrible, sorrow of my life. No change was made. The spirit that should have been brought into the whole work as the result of that meeting was not brought in because men did not receive the testimonies of the Spirit of God. As they went to their several fields of labor, they did not walk in the light that the Lord had flashed upon their pathway, but carried into their work the wrong principles that had been prevailing in the work at Battle Creek." (Ellen White, "Letter of Ellen White to J. Arthur, Jan. 14, 1903," in Manuscript Releases, vol. 13 (Silver Springs, MD: E. G. White Estate, 1993), 122.)

${ }^{194}$ George R. Knight, Organizing to Beat the Devil: The Development of Adventist Church Structure, 111. 
But in 1902 conflict between two branches and their leaders escalated. The two men, Kellogg and Jones, “would soon become deadly enemies with the denomination's new leader. Between 1901 and 1903 Jones would align himself with Kellogg in a power struggle against Daniells and W. W. Prescott...that came close to splitting the denomination in two." ${ }^{195}$ Gilbert M. Valentine explained that the significant efforts of Daniells and Prescott to try to meld the two branches did not succeed and faced stiff opposition. ${ }^{196}$ As a result, in 1902, the positive progress was reversed.

At the beginning of 1902, the church was affected by the first of two 1902 disasters: the main buildings of the Battle Creek Sanitarium burned to the ground. The Review and Herald offices experienced the same fate in December. Ellen White connected these disasters with her previous appeal for decentralization and the establishment of centers other than at Battle Creek. ${ }^{197}$ Kellogg disagreed with Ellen White and the church leadership on the issue of rebuilding or relocating the Sanitarium. While Kellogg successfully persuaded others to proceed with rebuilding, there was also a disagreement on the scale of rebuilding. The leadership of the church insisted on the moderate size of new buildings, and the budget limited to the cash on hand. The leaders were firm in their decision not to increase on the already monumental debt. That was contrary to the doctor's dream to put the Battle Creek sanitarium near the center of the

${ }^{195}$ Ibid.

${ }^{196}$ Gilbert M. Valentine, The Prophet and the Presidents, 222.

${ }^{197}$ She wrote, "In one year two of our largest institutions have been destroyed by fire. The news of this recent calamity caused us to mourn deeply, but it was permitted by the Lord to come upon us, and we should make no complaint, but learn from it the lesson that the Lord would teach us." (Ellen White, Ellen White to the Brethren in Battle Creek, 5 January 1903 (Berrien Springs, MI: Center for Adventist Research, Andrews University, 1903).) 
medical map of the United States. ${ }^{198}$ His intention to support the rebuilding of the institution with the controversial book The Living Temple ${ }^{199}$ created additional tensions.

The conflict between Kellogg and Daniells culminated in London on a personal level in mid-1902. Kellogg tried to persuade Daniells to have the GC borrow thirty thousand dollars for the medical institution in Britain. But Daniells firmly rejected the pressure of occurring any new debt before previous ones would be paid. During the fierce arguing, Kellogg even reminded Daniells that he is the chairman of the GC executive committee because of his influence. That unresolved conflict was so intense that it left the relationship between these two leaders ruined for good. ${ }^{200}$

Valentine explained that after returning from the London meeting, Kellogg actively influenced Daniells' friends and colleagues against him. ${ }^{201}$ At the meeting of the executive committee in November of 1902, Kellogg with his supporters made a concerted effort to elect Jones in place of Daniells as chairman of the denomination's Executive Committee. ${ }^{202}$ Even though that attempt failed, "all parties approached the meetings in a spirit of war. The issue at stake involved control of the denomination and its institutions."203

${ }^{198}$ See: Gilbert M. Valentine, The Prophet and the Presidents, 222.

${ }^{199}$ Some ideas in the book propagated a form of pantheism.

${ }^{200}$ Gilbert M. Valentine, The Prophet and the Presidents, 222-224.

${ }^{201}$ Ibid., 233.

${ }^{202}$ George R. Knight, Organizing to Beat the Devil: The Development of Adventist Church Structure, 112.

${ }^{203}$ Ibid., 114. 
The 1903 Session of the GC

The 1903 session of the GC dealt with the issue of organization again and completed the reorganization which had started in the 1901 session. At the same time, the leadership conflict revealed the weaknesses not only of Kellogg, but also of the new president of the GC, A. G. Daniells, whose excessive use of power Ellen White criticized after the 1903 session.

The first measure taken in 1903 was the result of the church's growing need to consolidate its finances and manage the problem of debt. However, that problem was solved more successfully than that of the centralization of the church. Three major steps had been taken in 1901. The Lake Union Conference had been requested to pay a second tithe, all local conferences with surplus in the treasury had been called to donate that money to the GC, and all churches had been asked to spend at least one month instructing their members on the payment of tithe. ${ }^{204}$ Other additional steps were taken in the months following the 1901 session: liabilities were transferred from the GC to the Union Conferences, and the GC was relieved of the administrative and financial burdens which belonged to the Union Conferences. ${ }^{205}$ Following these developments a new financial policy was voted, and the following resolution was accepted: "We recommend that the Treasury and Finance Department of the General Conference be broadened and

\footnotetext{
${ }^{204}$ General Conference of Seventh-day Adventists (Battle Creek, MI), General Conference Committee Minutes for 1901: Liquidation of General Conference Indebtedness, 2 November 1901, accessed August 8, 2014, http://documents.adventistarchives.org/Minutes /GCC/GCC1901.pdf.

${ }^{205}$ Gilbert Jorgensen, "An Investigation of the Administrative Reorganization of the General Conference of Seventh-day Adventists as Planned and Carried Out In the General Conferences of 1901 and 1903," 56.
} 
strengthened by the selection of treasurer of wide experience in the field, and the appointment of a sufficient staff or clerical help to do office work."206

The second important measure was the removal of the GC offices and publishing house from Battle Creek. The resolution stated, "that the General Conference offices or headquarters be moved from Battle Creek, Michigan, to some place favorable for its work on the Atlantic Coast." ${ }^{207}$ On August 10, 1903, the GC headquarters moved to 222 North Capitol Street, Washington, DC, and in 1905, was transferred to Takoma Park, Maryland/Eastern Avenue, Washington DC. The first issue of the Review and Herald to be published from Washington, DC, was in August 1903.

The third measure was the revision of the constitution adopted in 1901. This revision was an attempt to incorporate constitutional principles of reorganization which were not fully incorporated in the previous session. Jorgensen states that the revised constitution sought to put in place the following provisions: (1) To have an official head of the GC Corporation to avoid issues with signing legal documents, (2) To assure that the official head is elected by the people rather than by a small group, (3) To represent the leading departments of the denomination on the Executive Committee, (4) To ensure further departmental organization, and (5) To provide means of dealing with daily executive and administrative problems in the work throughout the world. ${ }^{208}$

206"General Conference Proceedings," The General Conference Bulletin, Thirty-fifth Session, April 7, 1903, 102.

207"General Conference Proceedings," The General Conference Bulletin, Thirty-fifth Session, April 6, 1903, 84.

${ }^{208}$ Gilbert Jorgensen, "An Investigation of the Administrative Reorganization of the General Conference of Seventh-day Adventists as Planned and Carried Out In the General Conferences of 1901 and 1903," 63-64. 
A careful comparison of the two constitutions reveals that the 1901 constitution was almost completely incorporated into the 1903 constitution. There were only four places where the text was changed. Nevertheless, the 1903 constitution is extended with additions "which dealt with the Executive Committee, officers and their duties, department, and financial arrangements." 209

The 1903 constitution reinstated the position of the president of the GC, defined the members of the Executive Committee, set a five-person quorum standard, defined a financial relationship between the particular organizational units, decreased the size of the board of trustees for the institutions in Battle Creek, and opened the door for the organization of future departments and institutions. Reinstatement of the presidential position had pragmatic reasons and caused some controversy. The constitution of the church from 1903 depicts the presidential role in Article V, Section 2: "The duties of the president shall be to act as chairman of the Executive Committee and to labor in the general interests of the Conference, as the Executive Committee may advise." ${ }^{210}$ At least in theory, the role of the president was expressed as a chairmanship, and the president was to be under the advisory of the Executive Committee, not vice versa. This was a continuation of the attempt at decentralization of power in the church.

The fourth measure defined ownership of institutions and their property. The accepted recommendation was "that the institutions were to be owned directly by the people, either the GC, Union Conference, State Conference, or Mission Field, and the

\footnotetext{
${ }^{209}$ Ibid., 56. 57.

${ }^{210}$ The General Conference Bulletin: Thirty-Fifth Session, vol. 5, The General Conference of Seventh-day Adventist Church (Oakland, CA: Pacific Press, 1903), 218.
} 
electors or constituents of each institution were to be the membership of the denominational body owning them." 211 This measure faced the strongest resistance from Kellogg and lead to the complete separation of the Sanitarium from the denomination.

It is also important to notice that the 1903 session did not finish with the same peaceful and optimistic tone as the previous one. A. T. Jones and his allies disagreed with the measures of the session, and they considered them as the reversal of the actions of the last session. They were particularly disturbed with reinstating the position of the president of the GC. Three of them ${ }^{212}$ were the members of the Committee on Plans and Constitution, and they expressed their disagreement in the form of the minority report presented by E. J. Waggoner. In the report, the measures were objected with three arguments: (1) the local church is supposed to be the core unit and standard, (2) the equality of all in the church opposes exaltation of one person over others (choosing the president), and (3) the authority to lead is derived from God's call, not from election, and reflect personal relationship between the individual and God. The minority report was not accepted, and a dissatisfaction of some who shared that viewpoint was expressed in the accusation that the church was moving toward the papal order. ${ }^{213}$

${ }^{211}$ Gilbert Jorgensen, "An Investigation of the Administrative Reorganization of the General Conference of Seventh-day Adventists as Planned and Carried Out In the General Conferences of 1901 and 1903," 72.

${ }^{212}$ E. J Waggoner, D. J. Paulson, and Percy T. Megan

${ }^{213}$ See: Barry David Oliver, SDA Organizational Structure: Past, Present, and Future, 233-239. 


\section{Summary}

The 1901 and 1903 sessions of the GC were the attempts of the Seventh-day Adventist Church to respond to the crisis that emerged from the rapid growth of the church, the centralizations of its institution and resources in one location, and the struggle for domination and control of the church and its institutions by its leaders. The two major theological viewpoints on the organization of the church emerged at the end of the nineteenth century. The first one emphasized the headship of Christ, the priesthood of all believers, the church as the body of the Christ, salvation by faith and that spiritual gifts have to determine the form of the church's organization. The second group's viewpoint assumed that the universal unity of the church has priority over individuality and the church needs organization that will support its mission. Oliver points out that the first group called for a congregational form of organization with an emphasis on diversity as the greatest value, and the second one for a hierarchical form of organization with unity as the highest value. Ellen White adopted a median position, and it called for a church polity which would combine elements of unity and diversity. While such outcome would be desirable, a strong defense of their positions and the prevailing of the second viewpoint resulted in movement toward the least desired outcome: centralization. ${ }^{214}$ During both sessions, supported by the process of theological debate, many practical measures were put into place to resolve these conflicts within the church. The 1901 session did not finish the necessary work of reorganization, but the 1903 session fulfilled that goal. The purpose of these measures was to uphold unity in diversity, eliminate kingly power, decentralize the church, solve financial problems, and empower

${ }^{214}$ Ibid., 270. 
the church for its mission. The most important steps taken during these GC sessions included: (1) creating the union of conferences and a larger Executive Committee, (2) placing the functions of the auxiliary organizations under the control of the GC, (3) developing a new constitution in the 1901 session and enriching it in the 1903 session, (4) generating policies for strengthening church finances, (5) moving the headquarters of the church to a new location, and (6) defining ownership of institutions and their property.

The conclusions of the session in 1901, together with additional developments arising from the session in 1903 , became the foundation of the current church organization. The decisions of the 1901 and 1903 GC sessions were pragmatic, but probably requisite, an answer to the problems of leadership which the church faced at that moment in its history.

\section{Conclusion}

The struggle of the church with the issue of kingly power highlights two facts of church existence: God should lead the church, and at the same time, the church needs a sound organizational structure led by able people. The reorganization of the Seventh-day Adventist church at the 1901 and 1903 sessions of the GC was the answer to that challenge. It was an attempt by the church to surrender authority and leadership to God and, simultaneously, create an organization capable of fulfilling that purpose. The process included the conflict of ideas and struggles over power yet led to practical measures. In spite of the controversy connected with kingly power and the unfortunate decisions of some leaders to leave the church, many of the results of that controversy were positive.

In the process of reorganization, the church created a preeminent model of church

government - the representative form of government. Power was dispersed by creating an 
organization with a functional hierarchy, with checks and balances to prevent the rulership and excessive power of individuals or small groups.

In theory, within this system of checks and balances, the local church is under the supervision of the conference, but at the same time, the churches control and evaluate the very same conference by the process of election. The local church is responsible to the conference she belongs to and the conference is responsible to the churches which are joined in it. The same relationship is established between the conferences and the unions, and it follows all the way to the GC. Unfortunately, in practice these check and balances are very rarely used.

The purpose of this unique organizational structure is to reflect God's authority in a church that is governed by humans. If applied correctly, this system can minimize the abuse of power in the church. Regrettably, the misuse of leadership cannot be prevented simply by creating a good organizational structure. Checks and balances are very important, and a good leadership model is important as well. But no humanly made system is perfect, and it seems that there is no human organization or organizational structure which has not at same point been abused by humans. The practical execution of any leadership model is highly determined by the behavior and decisions of the leaders in charge. Nevertheless, corrupted leaders are not the only ones to blame for abuses of power. Such leaders are also affected by the projected expectations of their subordinates. Though the church's attempt at organizational change was a step in the right direction, it was by itself an insufficient solution for the problem of the misuse of power.

Thus, the analysis of power abuses in the kingly power controversy uses the pattern from the second chapter to analyze two prominent church's leaders, Kellogg and 
Daniells, to see what can be learned from them to prevent the future misuse of power. The ethical analysis will concentrate on them and their abuses of power related to the kingly power issue. 


\section{CHAPTER 4}

\section{ETHICAL ANALYSIS OF ABUSES OF POWER}

The "kingly power" case is well documented in the scholarship on the history of the Adventist church. In this study, this case will be used for an ethical analysis of the abuse of power in the Seventh-day Adventist church. The misuse of power by two "titans" of Adventism, J. H. Kellogg and A. G. Daniells, - is the crux of the analysis. While this analysis relies on historical data, it is not a historical study of Adventist history. It attempts to fill the gaps that have resulted from the lack of an ethical analysis of the abuses of power. Consequently, as a study in ethics, it does not revise the history nor strive to find new historical information. It rather looks for ethical principles in the existent historical literature and goes to the primary historical sources only when clarification is needed. ${ }^{2}$

\footnotetext{
${ }^{1}$ Albert Dittes, Three Adventist Titans: The Significance of Heeding or Rejecting the Counsel of Ellen White (Ringgold, GA: Teach Services, 2013).

${ }^{2}$ In addition to the primary sources, this chapter relies on data from seminal works on the kingly power controversy in Adventist history. The sources used in the chapter include: ibid.; George R. Knight, A. T. Jones: Point Man on Adventism's Charismatic Frontier; Benjamin McArthur, A.G. Daniells: Shaper of Twentieth-Century Adventism; Benjamin McArthur, "A. G. Daniells and Lessons of Leadership," Adventist Today, Spring 2015, 2015; Jerry Moon, W. C. White and Ellen G. White: The Relationship Between the Prophet and Her Son; John J. Robertson, A. G. Daniells: The Making of a General Conference President, 1901; Richard W. Schwarz, "John Harvey Kellogg: American Health Reformer."; Richard W. Schwarz, "The Kellogg Schism - The Hidden Issues," Spectrum (Autumn, 1972); Richard Schwarz and Floyd Greenleaf, Light Bearers: A History of the Seventh-day Adventist Church; Richard W. Schwarz, John Harvey Kellog, M.D. - Pioneering Health Reformer; Woodrow W. Whidden, E. J.
} 
A focus of this study is on the leaders' abuses of power. An unintended consequence is that the leaders are portraited in a very negative light. Therefore, it should be noted from the beginning that the two leaders examined in this study have accomplished many noteworthy achievements. In spite of their human failures and misuse of power, they did important work for the church. The only reason for observing their abuses of power is to learn from their mistakes how to improve contemporary Christian leadership.

\section{Seven Types of Abuses of Power}

Being a leader is a very complex endeavor. According to the popular adage, "with great power comes great responsibility," leaders face the challenge of being responsible for the use of power. This study focuses on the negative aspects of the use of power by A. G. Daniells and J. H Kellogg, rather than discussing their significant achievements.

In this analysis of power abuse the pattern proposed in the second chapter will be applied. While the historical development and biographies of the leaders and their personal conflict provided the context in which specific power abuses happened, the proposed pattern groups particular abuses according to the reasons for their occurrence. It is important to understand that some of the effects and extensions of these abuses overlap. Ultimately, the final goal of this study is not to discern all the abuses accurately (and sometimes it is almost impossible to do so). This study strives to better understand the reasons for the occurrence of power abuse and to find ways to avoid a repetition of past mistakes and to find ideas on how to improve Christian leadership today.

Waggoner: From the Physician of Good News to the Agent of Division (Hagerstown, MD: Review and Herald, 2008); Gilbert M. Valentine, W. W. Prescott: Forgotten Giant of Adventism's Second Generation; Gilbert M. Valentine, The Prophet and the Presidents; Brian C. Wilson, Dr. John Harvey Kellogg and the Religion of Biologic Living. 


\section{Abuses Related to Misuse of Authority}

\section{Basic Premise}

The authority of Christian leaders originates in the authority delegated by God through the personal call and election of the church. Thus, Christian leaders are only the stewards of God's power and authority. Whenever they exercise power as if they were the ultimate authority or treat the church or institution they are in charge of as their own property, they overstep their authority, and thereby exhibit a form of kingly power.

\section{Pattern for Analysis}

An analysis of J. H. Kellogg's and A. G. Daniells' leadership presents how each leader misused their authority, how they put themselves above rules and/or laws or considered themselves the ultimate judges of what is right or wrong, and in which ways their leadership was autocratic.

\section{Analysis}

It is easy to criticize Kellogg for his domineering leadership style or his bad traits of character. However, would he have achieved as much if he had not had such traits? $\mathrm{He}$ had a vision and he pushed himself and his subordinates to achieve that vision. He also persuaded the whole church, including the church leadership, to invest energy, time, money and human resources in his vision. Therefore, it is possible that without him the church would not have accomplished as much. A strong leader like Kellogg is necessary to push an institution forward toward success. Each great achievement and success the church and its institutions accomplished required hard work, sacrifice, and persistence in spite of obstacles. Even A. G. Daniells admitted the greatness of the doctor's leadership, 
his mental acumen and ability, his great vision and goodness of his heart toward the needy and poor. ${ }^{3}$

On the other hand Kellogg's leadership also had negative aspects. In 1876 James White persuaded Kellogg to take over the Health Reform Institute (the predecessor to the Sanitarium). In the process of negotiations White accepted Kellogg's request to give him a free hand in reorganizing the institution on both a rational and scientific basis. ${ }^{4} \mathrm{He}$ requested such authority either because he knew the Institute was in serious trouble or/and because he personally believed in and practiced an autocratic leadership style. White's and Kellogg's mutual goal was to bring discipline and order to the Adventist institution, which was plagued with problems. ${ }^{5}$ Interestingly, Kellogg did not wait long to put in practice the "free hand" policy "approved" by White. Although he effected positive change and pulled the institution from the brink of disaster at times he wielded power without restraint. For example, he renamed the institution without consulting anyone and ignored the board that placed him in his leadership position. ${ }^{6}$ Kellogg's early leadership methods could be justified in the context of the institution's urgent need for change, but after the crisis was over he never altered his leadership style.

${ }^{3}$ Richard W. Schwarz, "John Harvey Kellogg: American Health Reformer," 77. (Based on Daniells statement quoted in P. T. Megan to Dr. Roy A. Falconer, August 4, 1921, Magan Papers.)

${ }^{4}$ Ibid., 175. (Based on Sanitarium Minutes, June 16, 1876; Kellogg, memorandum, November 11, 1922, RFB Kellogg Papers.)

${ }^{5}$ Ibid., 174. (Based on James White, "Eight Weeks at Battle Creek," The Review and Herald vol. 47, no. 22 (June 1, 1876): 172.)

${ }^{6}$ Richard W. Schwarz, "John Harvey Kellogg: American Health Reformer," 176. 
In theory, since James White granted Kellogg's request for complete control of the process of reorganization, Kellogg never overstepped received authority. However, White was probably unaware that Kellogg intended to use his authority so comprehensively. He probably assumed the figurative meaning of the phrase "free hand." The problem of autocratic leadership, which the church faced during the kingly power controversy, could partially be traced to the authority White (one of the founders of the church) rendered to the young Kellogg. According to Schwarz, Kellogg attempted to lead the institution without any assistance throughout his life. ${ }^{7} \mathrm{He}$ held absolute power over the institution. It seems that James White unconsciously overstepped his authority by granting Kellogg's request. Essentially, in the church, no one has the right to have a "free hand." Both leaders were expected to be in service to the Lord and the church, thus their authority was limited. The delegated authority they received from the church authorized them to manage the endeavors and the resources of the church and its members to advance the mission of the church.

Despite Kellogg's notoriety for his medical and humanitarian work in the annals of Seventh-day Adventist history, he never received a mandate to be the owner of the institution or its absolute ruler. His mandate was to organize the medical and later humanitarian work for the church and its members. However, after an attempt by his associates to remove him from his leadership position during his trip to Europe in 1883, he bought the majority of the shares in the sanitarium to maintain his control and prevent a similar event. By 1890 he owned the largest number of shares in the institution - three

${ }^{7}$ Ibid., 70. 
times more then next largest shareholder. At the beginning of the twentieth century, there was the belief that he had absolute control over the institution. ${ }^{8}$ In his public argument with Daniells during the 1903 GC session, he expressed his conviction that ownership meant control and it seems that was what Kellogg tried to obtain. ${ }^{9}$ It appears that maintaining his control over the institution was always his highest priority.

In the early years of his tenure, he accepted contributions from the church, as well as from outside the church, while he was still able to uphold the control. However, in later years he did not want to accept any outside contributions because he was afraid that it would be a threat to his control. His associate Ronald Harris accused Kellogg of deliberately undercutting and ignoring actions proposed by the Sanitarium Board whenever he disagreed with it. It seems that Kellogg was convinced that his way was the only right way. It was extremely hard for him to admit his mistakes, to apologize for them, or to change his mind after taking a particular position. ${ }^{10}$ His abuse of the position (taking ownership and ruling over the institution) was an example of a leader overstepping his mandate and consequently his authority.

In addition to wielding power without restraint over the Sanitarium, Kellogg had the exceptional gift of manipulating situations so that his interests were well served. Valentine describes in detail a specific event that occurred before the 1901 session of the

${ }^{8}$ Ibid., 178.

${ }^{9}$ Ibid., 381.

${ }^{10}$ Ibid., 223-224. 
GC. It was decided that the 1901 session of the GC would be held in Oakland, CA, but Kellogg was able to change that decision by political maneuvering. ${ }^{11}$

He was very strict in his supervision of the institution and insisted that all personnel adhere to the proposed health reform diet. From the beginning he required all physicians to conform to diet reform. He actually sat in the dining room at a "radical table" with only the doctors who complied with his plain radical diet. ${ }^{12}$ Despite this strict code, it still took him 20 years before he could report a total ban on meat, tea, and coffee in the Sanitarium. However, his strictness did not extend to other areas of health reform. For example, when he was criticized for overworking himself to the point of illness, Kellogg stated that he had to preach the health principles but he was not obligated to practice them. It appears that he could not see that his domineering attitude may have contributed to the hostility between him and the church leadership.

\footnotetext{
${ }^{11}$ When E. G. White returned from Australia to the United States, she looked for a new home in California. At her age she felt that warm, dry weather would be beneficial for her health, so she moved to Napa Valley, CA. Irwin, the GC president, wanted her to be present at the session, but she was not ready to travel in the winter. In compliance with the GC president's wish to have Mrs. White attend the conference and to bypass Dr. Kellogg and any other detrimental influences, the event was moved from Battle Creek to Oakland, CA. In protest Dr. Daniel Kress wrote E. G. White that the decision was a mistake and made just because of her. Then Kellogg himself visited her unannounced in her new home in California. He asked her if she would be willing to travel to Battle Creek if the session were held in the spring rather than winter. He even offered her medical treatments at the Sanitarium. As a result of Kellogg's visit, she wrote to President Irwin that she would be willing to attend the meetings if they were held in Battle Creek. Before receiving her letter, Irwin had already heard rumors about a change of location and time, and the meeting of 1901 was held in Battle Creek, MI. (Gilbert M. Valentine, The Prophet and the Presidents, 190-194.)

${ }^{12}$ Richard W. Schwarz, "John Harvey Kellogg: American Health Reformer," 180.
} 
Many years later, at the celebration of his ninetieth birthday, Kellogg said: "I've done what I wanted to do. I'd have been unhappy if I hadn't been allowed to do it." ${ }^{\text {13 }}$ This is how he described his life. At the same time, it is a reflection of his leadership style - an autocratic approach that imposed his will. Doing whatever a leader wants is the opposite of what Christian leadership is supposed to be: serving Christ and his followers, following what he wants us to do, and denying one's own personal goals and wishes if they are opposed to the leadership of Christ.

One of the typical excuses that Kellogg put forth for his autocratic leadership style was that there was no one else to do the job. ${ }^{14}$ Describing Kellogg, McArthur claims that he "was sure that he was always the smartest person in any gathering of Adventist leaders, ${ }^{15}$ and for him a loss of control was unthinkable. ${ }^{16}$ Actually, whenever things did not go his way, Kellogg threatened to quit. He apparently never quit. This tactic created the desired effect: he got more power. The idea of superiority and irreplaceability is another defense mechanism used by autocratic leaders to justify overstepping their authority.

While a leader's attempt to push his/her agenda is not necessarily an example of the abuse of power, it is a method often used by leaders to impose their authority. This method can undermine the authority and power of subordinates. Additionally, when a leader employs manipulation and behind-the-scenes schemes to overcome opposition and

${ }^{13}$ Quoted in: ibid., 44; From: Percy T. Magan, "John Harvey Kellogg, Apostle of Health," Health, July, 1942, 12-13.

${ }^{14}$ Richard W. Schwarz, "John Harvey Kellogg: American Health Reformer," 72.

${ }^{15}$ Benjamin McArthur, "A. G. Daniells and Lessons of Leadership," 9.

${ }^{16}$ Benjamin McArthur, A.G. Daniells: Shaper of Twentieth-Century Adventism, 193. 
an opponent's arguments instead of openly presenting all sides, they are overstepping their authority. Dishonesty and lack of transparency in conjunction with behind the scenes schemes is the modus operandi in the political world, but it is morally inappropriate in the church. Unfortunately, leaders who rule in the church use those methods to maintain control.

Checks and balances are necessary for controlling power, but putting them in practice is not an easy endeavor. Reacting to the misconduct of a leader, challenging his position, and sometimes even attempting to replace him is a very complex task. It requires the exercise of power that can counterbalance the power of the abusive leader. Campolo wrote, "Those who have sought to eliminate abusive political powers by the use of power usually become like the abusive system they challenged." ${ }^{17}$ It seems that that was the trap into which Daniells fell. In his effort to implement church policies and to put Kellogg's mostly independent institution under the Church's control, Daniells exceeded his authority. As can be observed from his disputes with Kellogg over establishing an institution in England, he was right to defend the principle but his method did not bring the right results. It seems that even though this issue was important for the whole church, the two leaders interpreted it as a personal conflict and attempted to answer the question who was right instead of deciding what was right. And it seems that the right thing to do would have been to compromise.

Daniells' impression that, as a leader, he had the responsibility to implement all policies in practice made his leadership very autocratic. McArthur asserted that, "Daniells

\footnotetext{
${ }^{17}$ Anthony Campolo Jr., The Power Delusion, 112.
} 
may have unconsciously seen himself as an Adventist Martin Luther, refusing to compromise a truth for expediency." ${ }^{18}$ E. G. White counseled Daniells: "Brother Daniells, God would not have you suppose that you can exercise a kingly power over your brethren." ${ }^{19}$ His strictness was affected by a strong conviction in the necessity of organization: "And I believe that the Holy Spirit will never work much in the midst of the distraction and confusion that always exists where there is no organization." 20

Ellen White very often counseled him to be more pragmatic and flexible in applying his power. While he regularly followed a deontological and Kantian leadership style, there were occasions when he employed very pragmatic arguments simply because they suited him. ${ }^{21}$ Though the responsibility of a leader is to uphold the principles of the institution he/she is in charge of, a leader leads real human beings with all their greatness and all their flaws. They are just as imperfect as their leaders. The result is a very complex relationship between the leaders and their subordinates. This is the reason why ruling by chain of command and with brute force seems to be the most efficient leadership model, and very often it is difficult to determine the appropriate amount of

${ }^{18}$ Benjamin McArthur, "A. G. Daniells and Lessons of Leadership," 8.

${ }^{19}$ E. G. White to A. G. Daniels, April 12,1903, Ellen G. White Estate; quoted from Albert Dittes, Three Adventist Titans: The Significance of Heeding or Rejecting the Counsel of Ellen White, 59.

${ }^{20}$ A. G. Daniells to Brother Starr, January 10, 1990, Ellen G. White Estate; Quoted from Albert Dittes, Three Adventist Titans: The Significance of Heeding or Rejecting the Counsel of Ellen White, 48.

${ }^{21}$ At the 1903 session of the GC Daniells responded to the minority report, which called for principles of the headship of Christ and the priesthood of all believers to be a basis for church organization, by saying: "Now I believe, brethren, that we must look at conditions. We face conditions, and not theories. We have to deal with what is before us, and not altogether with an ideal condition or ideal, situation." ("The General Conference Bulletin: Thirty-Fifth Session," 159.) 
power and authority to use. Irwin, Daniells' predecessor, touched upon this point when he stated, "I know from past experience that it is very much easier to pass the action than it is to carry it into effect." 22

To be effective, leaders need to use their authority and power. Very often without persistent effort and/or some sort of motivation, a decision and plan of action will not be put into practice. Therefore, leaders need to use the appropriate amount of power and authority to effect change. Daniells "was a chain-of-command person" and "he thought in terms of hierarchy and oversight." ${ }^{23}$ Consequently, he used inordinate pressure to compel others to follow church policy and to do what he thought was right.

Daniells tried to manage everything. John Robertson suggests that his urge to control led him to try to manage his own funeral. When we add to that Daniells' feeling of irreplaceability, stubbornness, determination, and his personality and inner motivation, it is no surprise that his leadership style seems strikingly similar to that of Kellogg. ${ }^{24}$

However, Jesus did not establish such a system in the church. He proposed love over fear, humbleness over greatness, equality - the priesthood of all believers - over rulership. According to the Christian worldview, there is only one head or leader in the church - God. And he, instead of using his unlimited power, simply loves. Sin and the ruler of this world have not been overcome by brute force, but by love and sacrifice.

${ }^{22}$ Quoted in Gilbert M. Valentine, The Prophet and the Presidents, 205.

${ }^{23}$ Benjamin McArthur, "A. G. Daniells and Lessons of Leadership," 8.

${ }^{24}$ John J. Robertson, A. G. Daniells: The Making of a General Conference President, 1901, 56-57. 
Whenever Daniells used his authority to control the church or to rule over his brothers, he was overstepping his authority.

Daniells had a talent for political maneuvering that was equal to that of his adversary, and he created a network of support among his subordinates. Ultimately, his correspondence was intended to diminishing Kellogg's influence. ${ }^{25}$ His overstepping of authority again comes from the wrong interpretation of his mandate to be the protector of the church and church policies. Here Robertson describes Daniells' leadership:

Obviously, this kind of man is not easily swayed. If a man's motivation is a combination of nervous energy and religious purpose, there is a tendency to confuse policy and principle. That is, whatever he does, he does because he acts upon principle. To be persuaded to do something he does not quite see or go contrary to what he does see would be most difficult. Practically every decision becomes a moral one. Hence, such a man may be termed either single-minded or stubborn, depending upon one's point of view. ${ }^{26}$

The tendency to confuse policy and principle was already mentioned in the discussion on the mosaic model in the Seventh-day Adventist Church Manual. A mandate wrongly understood can be used as an excuse by a leader to overstep his/her authority. Robertson points out an additional reason for the possible abuse of power: seeing all decisions through a moral lens. While all decisions Christian leaders make must be morally correct, many of their decisions do not include a moral dimension. What color should the church's walls be painted or which type of paper towel should the church purchase are both morally irrelevant decisions. Even many church policy issues are not moral issues, but leaders treat them as such to emphasize their point of view or to address

${ }^{25}$ Benjamin McArthur, A.G. Daniells: Shaper of Twentieth-Century Adventism, 192.

${ }^{26}$ John J. Robertson, A. G. Daniells: The Making of a General Conference President, 1901, 59. 
some other problem. ${ }^{27}$ Whenever somebody injects moral issues into morally neutral matters, they introduce the possibility of an abuse of power.

\section{Lessons Learned}

The conflict between Kellogg and Daniells was a conflict between two people with different ideologies but similar leadership styles. While Daniells' emphasis on a financial cash-based policy was the result of his inflexible realism, Kellogg's continuous enlargement of his endeavors was the result of his pragmatic (and often visionary) idealism. ${ }^{28}$ It was deontology versus utilitarianism. The dreamer met the realist, and instead of realizing that the church needed a combination of both to go forward, they wasted their combined energy on personal conflicts. So often abuses of power are simply the result of taking the extreme position instead of looking for the possibility of upholding the principles and applying them appropriately.

Both Kellogg and Daniells became leaders at the moment when their particular institutions were in crisis. Such a crisis usually requires leaders to employ leadership styles and methods that are improper outside of a crisis. While their authoritarian

${ }^{27} \mathrm{~A}$ good example is the ongoing debate in the Seventh-day Adventist Church regarding the issue of women's ordination. Ultimately, the issue does not address salvific matters nor any of the Church's fundamental beliefs. However, it is usually presented as a moral issue. If the debate had been presented as a policy issue instead of a moral issue, other important issues such as gender equality, the difference between "laity" and pastors or pastor vs. priest, the question of the biblical basis for our actions, the authority of the church, and the meaning of ordination could have been addressed. Therefore, if this issue (women ordination) had been presented in the appropriate context, it and other related issues might have been resolved many years ago. Unfortunately, the present state of affairs makes finding a satisfactory solution for a very diverse church extremely hard.

${ }^{28}$ Gilbert M. Valentine, The Prophet and the Presidents, 223. 
leadership style could be justified according to the problems they faced, their example also shows how hard it is to change leadership styles after the crisis is over.

While we need leaders who take their responsibility seriously extreme views regarding responsibility can be devastating for the quality of leadership. The main problem is that, in the spiritual setting, humans are never to replace God's leadership or the influence of the Holy Spirit with their personal interpretations. Leaders in the church are not to be inflexible bosses or controlling dictators. Their responsibility is not to change people or control institutions. Most of them are not called to be reformers, although all of them are called to uphold the highest principles in their own life and to share those principles with others. But applying the principle of the priesthood of all believers in practice gives others the same amount of responsibility as those in positions of leadership. It is true that sometimes leaders need to use their authority to achieve particular goals, but they do not need to rule in such a way that they overstep their authority and abuse the power given to them.

There are several important implications of the above study of the abuse of power: to minimize the abuse of power that comes with a leader's attempt to exceed his/her authority leaders must have a clear mandate as well as limits on the parameters of their authority. In addition, this study has shown that whenever leaders have the wrong picture of their term of office and/or their mandate, they are in danger of overextending their authority.

Christian leaders need to understand that Christ is the leader of the church and that some decisions do not concern moral questions. When morality is in question then they need to uphold principles and moral norms, but their job is not to enforce them by 
using coercive methods or by ruling over the people. Additionally, Christian leaders need to understand that they are required to put the interests of the church above their own. Transparency is necessary for Christian leadership; while political games belong to the political world, they do not have a place in the church. Describing the presidents of the Seventh-day Adventist church during the life of Ellen White, Valentine noticed that all of them had a hard time when they were removed from their offices and usually interpreted that as a personal failure. ${ }^{29}$ Thus, to apply their authority appropriately, Christian leaders must understand that they are replaceable, that their mandate is only for a limited amount of time, and that their responsibility and capability are limited within the boundaries of their mandate - to be servants of the Lord and of the people. When their authority or power is threatened their response must not be with power, but rather with principle and Christian love. Christian flexibility does not mean to live without principles either, but rather, it is an awareness of human limitations, the understanding that leadership should work within a limited mandate, and the ability to choose the lesser evil in the absence of a perfect solution.

Abuses Related to Mistreatment of Subordinates

Closely connected to the abuses of power related to the misuse of authority is the abuse of power related to the mistreatment of subordinates. While the mistreatment of subordinates is an example of a leader overstepping his/her authority, it is also a direct consequence of that type of abuse of power.

${ }^{29}$ See: ibid. 


\section{Basic Premise}

The power Christian leaders possess is delegated power for the benefit of the church and the people they lead. Christian leaders are the stewards of power received by God and not its owners. The use of this power is supposed to have two dimensions submission to God and service to his people. To put that power in the right perspective, Christian leaders are supposed to relate to their subordinates as equals, with Jesus being leader over all. Any deviation away from this type of relationship between leaders and subordinates results in abuses of power.

\section{Pattern for Analysis}

This section observes Daniells' and Kellogg's relations with their subordinates. The study will focus on their insufficient respect for their subordinates and the ways they treated them improperly. It discusses their use of coercive methods, such as brute force, inappropriate persuasion, and threats.

\section{Analysis}

The way both Kellogg and Daniells treated their subordinates reflected their very strong feeling of being responsible for their position. While their burden of responsibility will be addressed more thoroughly later, Schwarz points out that that feeling prevented Kellogg from being a team player. ${ }^{30}$ According to Robertson, the very same feeling, enhanced by dissatisfaction with the level of participation of other workers in church

\footnotetext{
${ }^{30}$ Richard W. Schwarz, "John Harvey Kellogg: American Health Reformer."
} 
activities, was the reason why Daniells was autocratic with his subordinates. ${ }^{31}$ As a consequence of his natural determination, combined with the problems he faced, he had a tendency to rule over his subordinates. ${ }^{32}$ While he was the conference president in Australia, Daniells very sharply criticized one of the conference workers who moved from Australia to New Zealand without asking permission for such a move. To his surprise E. G. White rebuked him for being too harsh and for jeopardizing this person's employment in Australia and his opportunities in New Zealand. In his defense, Daniells said that he wrote to his brother with care and kindness. He seemed to have been oblivious to the sharp tone of and the sarcasm in his letters and his behavior. ${ }^{33}$

Robertson argues that determination is necessary for effective leadership, but at the same time that quality can put a leader in moral jeopardy. ${ }^{34}$ Once again it can be seen that a particular quality necessary for effective leadership, namely determination, may be positive in and of itself. On the other hand, such a quality may also have negative aspects, especially when it is not controlled by an appropriate understanding of one's mandate and circumscribed by respect for and appreciation of one's subordinates.

Daniells assumed that an employee must be completely subordinate to the committees and leaders in charge. Thereby, he expected complete submission from his

\footnotetext{
${ }^{31}$ John J. Robertson, A. G. Daniells: The Making of a General Conference President, $1901,56$.

${ }^{32}$ Ibid., 61.

${ }^{33}$ Ibid., 68; Benjamin McArthur, A.G. Daniells: Shaper of Twentieth-Century Adventism, $61-62$.

${ }^{34}$ John J. Robertson, A. G. Daniells: The Making of a General Conference President, $1901,61$.
} 
subordinates. During his Australian years, this view led him to consult with only a few subordinates while basically ignoring others, making them feel completely isolated. ${ }^{35}$ In 1894 E. G White warned him that if he did not change, he would have to be replaced. ${ }^{36}$ He was self-sufficient and believed that only his opinion was right. During his conflict with Kellogg, Daniells forced from denominational employment people who refused to denounce him with the vigor Daniells expected. ${ }^{37}$

Based on Daniells' example, Robertson noticed that in spite of the biblical teaching of the priesthood of all believers, officers of the institution and their subordinates have an employer-employee relationship. ${ }^{38}$ This can create a discrepancy between the ideal teaching of the priesthood of all believers and the practice of the leaders. Probably, the aspect that generates this discrepancy is the fact that the administration of the church uses the hiring process. In addition, it is also viewed as the entity that pays for pastoral work. Such a state of affairs obviously leads to the possibility of a boss-subordinate relationship. (If you do not comply with my position I will fire you.) Simply having a board might be insufficient to prevent abuses based on this business model and based on the relationship it creates. Consequently, abuses of power in such a system arise. While practicality necessitates organizational structure and functional hierarchy, in the church there is no boss. The conference, the president, the treasurer, and any other functionary of the institution are all servants of the head (God)

${ }^{35}$ Ibid., 68.

${ }^{36}$ Ibid., 60.

${ }^{37}$ Richard W. Schwarz, "John Harvey Kellogg: American Health Reformer," 396.

${ }^{38}$ John J. Robertson, A. G. Daniells: The Making of a General Conference President, $1901,67$. 
and in service to each other. Even though they have different responsibilities and consequently different levels of authority, they are not to rule over each other. By considering the institution or any dignitary of that institution the boss, the church is disregarding specific biblical principles and taking power from Christ and putting it in the hands of the institution or the individual representative of that institution. That can set a very dangerous situation in which a particular institution is assuming power that was never given by God.

In practice, probably as a result of a combination of outside influences, ${ }^{39}$ an incorrect understanding of spiritual leadership, and human (therefore sinful) nature, that complex balance between the equality of all believers and functional hierarchy in which every part of the body correctly applies power and influence is rarely reached. In his assessment of Daniells' leadership, Robertson suggested the pragmatic model is only one possible form of leadership, with executive leaders in the position of judges in relation to employees. However, it seems that it is necessary to challenge that relationship with the plain biblical teaching that in the church there is only one ultimate authority: "But you, do not be called 'Rabbi'; for One is your Teacher, the Christ, and you are all brethren." (Matt 23:8 New King James [NKJ]) How to combine two opposing requirements of Christian leadership, functional organization (which is obviously calling for functional hierarchy) and an appropriate "all brethren" relationship, is one of the biggest challenges for church leadership. That has to be the ultimate goal; it needs to be kept in mind and it has to be included in leadership practice. In addition, whenever the church moves toward any of the possible extremes - the absence of organization (because of lack of respect for

\footnotetext{
${ }^{39}$ Such as a non-spiritual leadership models.
} 
rightful authority received from God or rulership) or the presence of the abuse of power (because leaders are taking authority which does not belong to them) - the members of the church need to raise their voices against such misuses of power. The reformation of the church and spiritual leadership always must be a work in progress.

Kellogg is a good example of the fact that abuses of power do not happen in a vacuum. Usually, there is an enabling environment that allows the abuser to stay in power. It requires the support of associates and the acceptance of subordinates. Kellogg probably would not have initially retained his strong position without his patron J. White. He needed support to get in a position of power, but he needed acceptance by and support of his subordinates to stay in that position. W. C. White claimed that his mother believed that during the last attempt to reconcile the two branches of work in Berrien Springs, MI in 1904, Kellogg could have been saved for the Adventist cause if his associates had not supported him but rather stood for the truth. ${ }^{40}$ There is an interesting implication of this comment. It appears that on some occasions the best course of action to help the leader that is abusing the power is to stand for the truth and help him face the reality of his action. At the same time, it seems that might be the hardest thing to do because it can cost the subordinate his/her position or job.

Many of the incidents of Kellogg's mistreatment of subordinates had their roots in his supremacy. His associate Ronald Harris accused Kellogg of deliberately undercutting and ignoring certain actions taken by the Sanitarium Board whenever he disagreed with it. Kellogg's mistreatment of his colleagues was affected by his conviction that they are wrong. While he was probably sometimes (or even often) right, being right all the time is

\footnotetext{
${ }^{40}$ Richard W. Schwarz, "John Harvey Kellogg: American Health Reformer," 402.
} 
a symptom of Kellogg's personality that unfortunately adversely affected others. In the late 1930s, another one of Kellogg's assistants quit his job because he felt that he never delegated authority or work. ${ }^{41}$ Throughout his life, when any of his associates disagreed with him, he became very suspicious of them. ${ }^{42}$ E. G. White also accused him of "a love for supremacy," 43 which led to the diminishing of the potential of his associates and to Kellogg treating them differently from how he would have wanted to be treated if he was in their place. ${ }^{44}$ Dr. W. T. Lindsay and Dr. W. S. Sadler believed that Kellogg's unwillingness to share responsibility was due to his jealousy or fear of potential competitors. $^{45}$

A good example of his idiosyncratic method of dealing with competition is his conspiracy with S. N. Haskell and G. I. Butler to remove James White from the Sanitarium Board and replace him as the chairman of the institution with Haskell in 1880. Schwarz explained that the reason for that plot was Kellogg's fear of working with someone like his mentor J. White, who had a dominating personality. ${ }^{46}$ To develop a more complete picture of this situation, it is important to mention that J. White

${ }^{41}$ Ibid., 70; Letter A. L. Baker to P. T. Magan, November 8, 1939, Magan Papers.

${ }^{42}$ Richard W. Schwarz, "John Harvey Kellogg: American Health Reformer," 71.

${ }^{43}$ Ellen White, Manuscript Releases: From the Files of the Letters and Manuscripts, vol. 2 (Washington, D.C.: E. G. White Estate, 1987), 240.

${ }^{44}$ Letter 7 - E. G. White to J. H. Kellogg, April 26, 1886, Ellen G. White Estate Branch Office Document File.

${ }^{45}$ Richard W. Schwarz, "John Harvey Kellogg: American Health Reformer," 72; Letter Dr. W. T. Lindsay to R. W. Schwarz, May 23, 1961.

${ }^{46}$ Richard W. Schwarz, "John Harvey Kellogg: American Health Reformer," 177. 
encouraged and financed Kellogg's education and persuaded him first to become a medical doctor, and then to take over the Health Reform Institute.

It seems that the Doctor was incapable of sharing responsibility, even with people who possessed different expertise than his own. When, according to W. T. Lindsay, his assistant would start to build his own reputation "it soon became necessary - health wise - for him to move to other parts of the world. ${ }^{47}$ Fear of competition and the need to be in control prevented Kellogg from developing more leaders who would, like him, affect the work positively. It led him to treat them inappropriately. He really behaved like the ultimate boss who is surrounded with people who have only two choices: follow his leadership or leave.

His feeling of superiority and lack of trust were the reasons why Kellogg taught others so rigorously. Kellogg considered the ministers as inferior to the doctors because of their lack of education, lack of financial acumen, shortsightedness regarding the medical work, and their domineering attitude toward medical personnel. He also held the view that all of the presidents of the GC opposed his work. ${ }^{48}$ The pastors further frustrated Kellogg because they did not practice the health reform principles,${ }^{49}$ which he

${ }^{47}$ Quoted in: ibid., 72; From:Letter Dr. W. T. Lindsay to R. W. Schwarz, May 23, 1961.

${ }^{48}$ See: Richard W. Schwarz, "John Harvey Kellogg: American Health Reformer," 351; Letter J. H. Kellogg to S. N. Haskell, June 18, 1905, MSU Kellogg Papers; Brian C. Wilson, Dr. John Harvey Kellogg and the Religion of Biologic Living, 109.

${ }^{49}$ Richard W. Schwarz, "John Harvey Kellogg: American Health Reformer," 348; Letter J. H. Kellogg to W. C. White, April 12, 1875, E. G. White Papers; John Harvey Kellogg, "Serious Thoughts for Serious People," The Review and Herald vol. 63, no. 1 (January 5, 1886): 2.

Kellogg attended many church-organized meetings to educate members and leaders of the church about those principles, but without satisfactory results. 
(Kellogg) viewed as mandatory by the church. ${ }^{50}$ Kellogg admitted that he might have been partially to blame for their attitude because of the pressure he put on the ministers. ${ }^{51}$ In addition, he was also remiss in practicing all of the health reform principles. He said: "I am under no obligation to practice what I preach. My business is to preach and really I haven't time to practice... I am looking after other people's health and my own health has to take the best chance it can." ${ }^{, 52}$ His carelessness with his health almost cost him his life in 1918 when he spent seven months in bed because he overworked himself and did not get enough sleep, which resulted in exhaustion. While such behavior, having double standards, is common in the business world or in politics, it is inappropriate in spiritual leadership. The leaders and followers as well have the same obligation to practice what they preach. Although it is very hard for human beings to uphold every principle, it is absolutely, morally inappropriate for the spiritual leaders to impose on the followers the requirements that they do not apply to themselves. Ideally, they are supposed to lead by example, which is the strongest validation of their preaching.

Kellogg also mistreated his associates by claiming that he cared for people under his leadership when in practice he offered his employees substandard service to save money. E. G. White reproved him for serving the Sanitarium workers low-quality food to save money. ${ }^{53} \mathrm{He}$ also decided to pay his workers as little as possible. When he fought to 203.

${ }^{50}$ See: Richard W. Schwarz, "John Harvey Kellogg: American Health Reformer," 202-

${ }^{51}$ Ibid., 348.

${ }^{52}$ Quoted in: ibid., 54; From:MS account of the events connected with Dr. Kellogg's sixtieth birthday celebration, February 26, 1912, RBF Kellogg Papers.

${ }^{53}$ Richard W. Schwarz, "John Harvey Kellogg: American Health Reformer," 81. 
keep the Sanitarium after the expiration of its charter in 1897, the argument Kellogg used was that the Sanitarium workers were working for meager pay because they considered their work as a service to the Lord. They wouldn't have agreed to work for so little otherwise. ${ }^{54}$

On the other hand, even though it is not possible to determine his income because of the absence of his personal financial records, there is evidence that he was just as meticulous with his personal finances. There is also evidence that his income was used, under his supervision, to pay the expenses of poor patients. Some of his secretaries claimed that he used part of his salary for professional expenses and charity. ${ }^{55}$ According to Kellogg: "I could have accumulated a fortune, but what is money for except to make the world better, to help people to have a better life?" ${ }^{56}$ While his behavior toward his subordinates could be interpreted as abusive, it also reflects his personal worldview.

\section{Lessons Learned}

The causes for the abuses of power related to the mistreatment of subordinates can be found in the following: a misunderstanding of the real nature of Christian leadership, a wrong understanding of the mandate/authority of leaders, the wish to be in control, and the feeling of superiority. Though in theory most Seventh-day Adventists today, as well as the pioneers of the movement, would agree that Christ is the leader of the church, and endorse the biblical teaching of the priesthood of all believers, one can

\footnotetext{
${ }^{54}$ See: John Harvey Kellogg, "Rise and Development of the Sanitarium Work," The Gospel of Health vol. 2, no. 8 (August 1898).

${ }^{55}$ Richard W. Schwarz, "John Harvey Kellogg: American Health Reformer," 82-83.

${ }^{56}$ Quoted in: ibid., 85; From: A. E. Wiggam, "The Most Remarkable Man I Have Ever Known," American Magazine, December, 1925.
} 
observe a discrepancy in church practice. An inadequate understanding of the mandate, authority, and responsibility of leaders, and the influence of leadership practices from non-Christian models, is reflected in the incidence of autocratic leadership. The ultimate result is a diminishing of the authority and power of a leader's subordinates in addition to their mistreatment.

In order to prevent those sorts of abuses leaders, as well as subordinates, need to be constantly reminded of the nature of their leadership and of who is the head of the church. Awareness of the equality of all believers and of the fact that all are servants of the head, as well as that their responsibility is to serve the needs of the church and of each other, needs to control the urge to control and rule. Ideally, all church members are united under the same mission and mandate to be stewards of the Lord. While each person has different duties, there needs to be checks and balances regarding the overall mandate so that the members can stand together against any inappropriate action.

\section{Abuses Related to Preservation of Power}

One of the causes of the mistreatment of subordinates is the desire for the preservation of position of power. Removing or controlling the competition is the resultant method, and the reasons could be insecurity, as well as the feeling that being and staying in power is a question of personal success and honor. It seems that losing authority and power means, for most leaders, powerlessness or personal failure.

\section{Basic Premise}

While in a position of power Christian leaders are supposed to emulate the leadership of Jesus Christ - emptying themselves of power, and using their power and authority to benefit and do good to others. They are supposed to put their own interests 
after, the interests of others. Although, without being in a position of power they would not be able to make beneficial changes, leaders tend to concentrate on power, place their own interests first, and engage in the preservation of personal power, which is contrary to the example of Jesus and are examples of abuses of power in Christian leadership.

\section{Pattern for Analysis}

Similar to all spiritual leaders, Kellogg and Daniells faced the dichotomy of Christian leadership - being in a position of power and submitting their power to God and serving to their subordinates. An assessment of their experience will assist in understanding why the preservation of power leads to abuses of power. The assessment will start with the following questions: 1) Did the two leaders share power and position only with those whom they could control? 2) Did the two leaders try to control others and situations with rumors, gossiping, and dishonesty?

\section{Analysis}

We have already described Kellogg's leadership style, which led to the mistreatment of his subordinates. But those examples also show that if anyone appeared to threaten his leadership, it would have been best if they departed because Kellogg would not allow that person to outshine him. He tried hard to stay in a position of power by not sharing leadership and other responsibilities with others. He even did not hesitate to plot to remove from leadership James White, the one who put him in his position in the first place. The free-hand policy that the board gave him, at his request, not only gave him the opportunity to fix problems in the Institute, but also allowed him to preserve his position of power. He probably believed, and impressed others with this belief, that his leadership was essential for the success of the medical work. He justified all of his 
actions with the idea that things would not get done if he behaved differently or that no one else would do it if he did not. The belief that only one person is the best choice for a particular position of power, gives that person the security of holding on to their position of power. As long as Kellogg was able to remove his competition and continue to make others believe that he was irreplaceable, he did not have any reason to worry about the security of his position.

Campolo stated, "Most people play power games."57 Most leaders, including spiritual leaders, play them too. Although power games are inappropriate for Christian leaders, Kellogg seems to have played them very successfully. It was already pointed out - whenever he wanted to strengthen his leadership position, he threatened the institute administrative board with his resignation. In 1899 E. G. White sent Kellogg the letters in which she criticized his autocratic leadership style, which included gathering too much power to himself and boasting about the manner in which he attained power over others. Included in her list of complaints was also the accusation that he and his associates behaved in a selfish and covetous manner by using all of the profits for themselves and not sharing it with other struggling institutions. ${ }^{58}$ Kellogg responded to E. White's letter with a letter of his own in which he said that his only option is to step down and offered his "resignation of all and every connection of the active work of the Seventh-day

${ }^{57}$ Anthony Campolo Jr., The Power Delusion, 9.

${ }^{58}$ Richard W. Schwarz, "John Harvey Kellogg: American Health Reformer," 369; Letter 3 - E. G. White to J. H. Kellogg, January 5, 1899, Ellen G. White Estate Branch Office Document File; W. Bennis, "Become a Tomorrow Leader," in Focus on Leadership Servant-Leadership for the Twenty-First Century; K. Blanchard and P. Hodges, The Servant Leader: Transforming Your Hearts, Heads, Hands, and Habits. 
Adventist church. ${ }^{{ }^{59}}$ The wording of the second claim is interesting. It mentions his resignation from church-connected jobs and boards, but does not mention the sanitarium or any institution of which he was in charge. It is hard to determine if Kellogg's offer of stepping down was a serious decision at the moment when he faced criticism of his work, or simply another power game in which he tried to strengthen his position with the threat of resignation. This tactic often helped him to preserve his power. This time not only did he keep his position, but he would soon completely separate from the church the institutions of which he was in charge. It is also evident that even in moments when he was ready to sever his connection with the church, he never planned to leave "his" institutions.

Another aspect of the idea of irreplaceability was the image of Kellogg's success in his endeavors. The Battle Creek Sanitarium was very often referred to as the Kellogg Sanitarium in the press and in public. ${ }^{60}$ While this reflects the importance of Kellogg's leadership and his significance for the institution, it is also the result of his possessive attitude and his autocratic leadership style in which he treated the Sanitarium as his own endeavor or property. While he was protecting his leadership position, his actions were on a collision course with the denominational origin and purpose of the Sanitarium. He admitted that the separation of the institution from the church was part of his plan and something that he expected in the future. After the separation from the church had successfully been accomplished, Kellogg stated he would be required to prevent the attempts of certain Adventist ministers to place the Sanitarium under the direct control of

\footnotetext{
${ }^{59}$ Richard W. Schwarz, "John Harvey Kellogg: American Health Reformer," 369; P. M. Senge, "Afterword," in Servant Leadership: A Journey Into the Nature of Legitimate Power.

${ }^{60}$ Richard W. Schwarz, "John Harvey Kellogg: American Health Reformer," 181.
} 
the GC. In 1905 he stated that he had anticipated the separation of his institution from the church as early as the 1890 s. ${ }^{61}$ This appears to have been an attempt to secure his leadership position as well.

His personality will be discussed further in the section about character, but for Kellogg it was very hard to admit to his mistakes or to apologize. That was especially evident during the last attempt at reconciliation when others involved in the conflict admitted their mistakes and asked for forgiveness, and he said that he does not have reason to do the same because he did not do anything wrong. ${ }^{62}$ It seems that he applied Machiavelli's postulate that it is better to be feared than loved because, according to some, he treated his enemies better than his friends. ${ }^{63}$

One of the methods he used to deal with opposition and to preserve power was to use criticism and gossiping. At the time of his separation from the church his actions and behavior were criticized by E. G. White. She tried to help him and to keep his institution in the church. While Kellogg previously endorsed her spiritual gift and strongly supported all the Testimonies related to health, he responded to her criticism by seriously questioning her spiritual gift. George Butler concluded that the reason for Kellogg's new attitude toward the Testimonies was the fact that most people accepted the Testimonies

\footnotetext{
${ }^{61}$ Ibid., 358.

${ }^{62}$ Ibid., 71, 402.

${ }^{63}$ Ibid., 71.
} 
when White's statements favored their position; however, when her statements reproved them most people contested their authority. ${ }^{64}$

It seems also that Kellogg's new attitude toward E. G. White's gift was influenced by his bias against William White, Ellen's son, who was involved in her work and later became his mother's caregiver. Kellogg accused him of influencing his mother and of forging her signature ${ }^{65}$ While Kellogg claimed that he wanted to continue the childhood friendship he had had with William, their relationship was not always cordial. The fact that William was married to a woman that Kellogg had previously wanted to marry may have negatively influenced their relationship. For some time, Kellogg tried to maintain a good relationship with William in an attempt to prevent him from joining the other three Adventist leaders Kellogg believed were plotting against him: A. G. Daniels, W. W. Prescott and I. H. Evans. But when this plan failed, he openly accused W. C. White of being a manipulator who acted like the "general manager of the universe." He also accused him of not standing for his principles and of being intimidated by Daniells. ${ }^{66}$ This was not unusual for Kellogg. Attacking a competitor and intimidating him/her was his way of preserving power.

Daniells' behavior and his use of power were similar to that of Kellogg. Robertson describes his practices by stating that: “A. G. Daniells was a controversial

${ }^{64}$ Ibid., 367; M. Wheatley, "The Work of Servant Leader," in Focus on Leadership Servant-Leadership for the Twenty-First Century.

${ }^{65}$ Richard W. Schwarz, "John Harvey Kellogg: American Health Reformer," 365.

${ }^{66}$ Ibid., 391-392. 
figure, but is it possible for a dynamic leader to be otherwise?"67 He loved the church and dedicated his whole life to it. But like Kellogg, he was aware that in order to influence the church he had to be in a position of power. As was already mentioned, he believed that his responsibility was to protect the church. In his zeal to fulfill his duty he had the tendency to prefer rules to practicality, even in situations where pragmatism was justified. E. G. White reproved him for his treatment of his subordinates and for cutting the wages of S. H. Haskell, who worked in New York to supplement his salary. ${ }^{68}$ Even though Daniells' decision could have been justified as an attempt to equalize the wages of employees, he disregarded the fact that living expenses were different in different places and that Haskell was returning whatever he earned after living expenses to the church. ${ }^{69}$

Evidently, the ability to determine wages places a significant amount of power within the hands of a leader. This employer-employee relationship can be perceived as Daniells' way of controlling others and of preserving his position of power. Ordinarily, there are consequences for not obeying one's boss because he has the power to make decisions that can affect one's life. Therefore, facing the employer's authority in making such decisions, it is less likely that a subordinate will confront his/her superiors concerning ethical matters. In addition, the power to determine wages can easily become a tool of manipulation and control by an unprincipled leader.

\footnotetext{
${ }^{67}$ John J. Robertson, A. G. Daniells: The Making of a General Conference President, 1901, 115.

${ }^{68}$ Ibid., 70.

${ }^{69}$ Ibid.
} 
While personally being an expert in manipulation, Kellogg accused Daniells of manipulative leadership: "The schemes of Daniells and Prescott to become rulers over Israel are in direct opposition to the whole plan of reorganization which the Lord gave us through you at the last General Conference." 70 If one adds to this statement Ellen White's claim that Daniells used kingly power as a leader, one can conclude that Kellogg's accusations might not be without basis. While in Kellogg's case it is much easier to extract the episodes from his life that show him playing political games and using manipulation in order to keep his position, in the case of Daniells the abuses occurred as a result of his insistence on strictly adhering to rules and policies. But when this insistence on strict adherence to policy diminishes the importance of one's fellow human being, it becomes just another abuse of power and another method to preserve one's position of power. On some occasions it seemed that that was Daniells' intention. Concerning the issue of the publishing house and its control, he was able to put Prescott, Evans and himself on the board and to remove Uriah Smith from his editorial position in the Review and Herald. He accomplished this by degrading his position to the associate editor, and after thirteen months Smith was out of his position. Daniells' act of gaining control of the Review and Herald opened the door to the sharing of information and influence in the church. Thus, previous leadership was presented as antagonistic to progress and change. ${ }^{71}$

\footnotetext{
${ }^{70}$ Kellogg wrote many letters to Ellen White in his attempt to overthrow the Daniells administration at the 1903 session of the GC. This is text from one of them. (Gilbert M. Valentine, The Prophet and the Presidents, 244.)

${ }^{71}$ Benjamin McArthur, A.G. Daniells: Shaper of Twentieth-Century Adventism, 152-153.
} 
A tendency toward political maneuvering can be observed in Daniells' way of presenting things. In his description of moving the publishing house from Battle Creek to Washington, DC, McArthur noticed that Daniells' description of events did not reflect what happened entirely. His description omitted the change in his views during times of decision-making, the fact that Ellen White initially urged them to purchase property in New York, and the influence of Pastor J. S. Washburn who lobbied for the move to Washington, DC. Daniells presented the decision as God's providence and insisted that the counsels of Ellen White were diligently applied. While this could be the result of an attempt to simplify a very complicated story, it might have the purpose of emphasizing God's approval of the church leadership's actions, and it might be Machiavellian in nature. It creates an image or appearance of leadership that is in complete accordance with divine leadership. That ultimately puts more authority and power in the hands of leaders. $^{72}$

That Daniells was not immune to the challenges of being in power can be observed by the fact that when, after 21 years as president, when he was removed from his position he resisted the change. This incident in his life reflects the struggle most leaders have when they lose their position of power. ${ }^{73}$

Daniells' attempts to preserve his power can also be detected in his use of his personal experience as a confirmation that God had placed him in the leadership position. Valentine points to at least two personal experiences Daniells used to confirm his

\footnotetext{
${ }^{72}$ Ibid., 163.
}

${ }^{73}$ John J. Robertson, A. G. Daniells: The Making of a General Conference President, 1901. 
leadership authority - 1) seizures followed by a dreamlike premonition and 2) a timely letter sent from someone who prayed for him. According to Daniells, these were signs that God was with him. ${ }^{74}$

Daniells used a similar kind of spiritual confirmation to justify his firmness in his conflict with Kellogg in Europe. In his letter to W. C. White, Daniells described his experience when he was on his way to the European meeting: "Late at night a voice seemed to be speaking to my conscience telling me that I must not surrender to wrong principles, and thus bring serious troubles upon the cause of God." He then stated that he did not understand the message. Before he reached London he understood the message as a call not to give approval to any plan that would lead to more debt. ${ }^{75}$ His description of the experience is a good example of how easy it is to employ a spiritual excuse for the abuse of power. McArthur calls them "a kind of divine private counsel."76 When spiritual experience is employed as an argument in support of a particular position, it is very hard to prove that an abuse of power has occurred. Ronald M. Enroth in Churches That Abuse says: "Unhealthy, authoritarian leadership encourages people to place their pastors on pedestals." ${ }^{77}$ In relation to spiritual leaders, what would place them on a pedestal more than the use of a spiritual experience as the confirmation of his/her authority? Such experiences usually cannot be tested or examined, the accuracy of reports cannot be checked, nor the

${ }^{74}$ Gilbert M. Valentine, The Prophet and the Presidents, 242.

${ }^{75}$ Benjamin McArthur, A.G. Daniells: Shaper of Twentieth-Century Adventism, 187; From: H. Richard Niebuhr, Christ and Culture.

${ }^{76}$ Benjamin McArthur, A.G. Daniells: Shaper of Twentieth-Century Adventism, 187.

${ }^{77}$ Ronald M. Enroth, Churches That Abuse (Grand Rapids, MI: Zondervan Publishing House, 1992), 42. 
honesty of the leader who claims it. That is the reason why abusive leaders often employ similar spiritual arguments: it increases and preserves the position of power of the leader. In addition to personal experience, Daniells was using the prophet of the church to advance his own cause. As McArthur asserts, "Ellen White's prophetic status meant that church leaders sought to influence policy by employing the oracle's words to bolster their position. Daniells was as guilty of this as anyone." 78

According to Robertson Daniells practiced another method of strengthening his leadership position. When he took the ideas of others and put them into practice, if the ideas were successful, he would take the credit for them. ${ }^{79}$ In The 48 Laws of Power one of the laws or methods of preserving power is to use the ideas of others and take credit for them. ${ }^{80}$ This Machiavellian method was used by a Christian leader. Although his motivations cannot be judged objectively, this obviously contributed to his preservation of power and, whether it was a conscious decision or not, it was an abuse of power.

While the struggle between Kellogg and Daniells was a struggle between two different ideologies and points of views, it was also a personal conflict. In 1902 and at the 1903 conference session Kellogg pushed for a change in leadership by accusing Daniells of being an autocratic leader. In response to Kellogg's attacks Daniells made a counterattack, possibly a defense mechanism, and accused Kellogg of exerting kingly power. The fact that both men were reproved for such behavior means that both were right and both were at fault. They used powerful methods to get their way, which was

${ }^{78}$ Benjamin McArthur, A.G. Daniells: Shaper of Twentieth-Century Adventism, 147.

${ }^{79}$ John J. Robertson, A. G. Daniells: The Making of a General Conference President, 1901, 82.

${ }^{80}$ Robert Greene and Joost Elffers, The 48 Laws of Power. 
contrary to their mandate and authority. The main problem was that both, while attacking the other, disregarded their own behavior, which they obviously justified by asserting their responsibility to prevent the abuses of the other. While their behavior was largely the result of their belief that their mission was to protect the church, institution, or work, their actions served to preserve their position of power.

Contrary to some of their claims, it is obvious that neither one was ready to leave his position of power. It is true that, in the end, Daniells stayed with the church and even corrected some of his misbehavior, and Kellogg left the church and took the property of the church as his own, never admitting his errors. Unfortunately, the behavior of neither one of these leaders can be approved if they are assessed through lens of Jesus' example.

\section{Lessons Learned}

Power games are usually the products of selfish motives, but even when they come as the result of good goals or intentions Christian leaders should avoid them. Most likely they are a consequence of a desire to be in control and in charge. According to Campolo, Nietzsche understood the nature of Christian leadership better than many Christian leaders: "Nietzsche clearly saw the hunger for power as anti-Christian. Consequently, he declared that Christianity should be abolished because it asks people to surrender to God, to render themselves as weak vessels to the Lord, and to reject attempts to exercise power over others... He knew that Christ's call to servanthood and humility precludes all power games, and that Christ asks us to live contrary to our true nature." 81 Following Christ's example, spiritual leaders must cease all attempts for power and

\footnotetext{
${ }^{81}$ Anthony Campolo Jr., The Power Delusion, 10-11.
} 
personal gain, which ultimately stem from selfishness. Instead, they have to prioritize their goals and actions to fulfill the mission of their master and serve his institution as well as all humanity.

Abuses related to preservation of power might to be one of the hardest abuses of power to prevent. The prevention of those abuses requires leaders to have a proper understanding of the goal of Christianity, which is not personal glory, but doing good to others and advancing God's Kingdom. While leaders in charge very often consider their removal from the position as an attack on their legacy, they need to know that they are not irreplaceable, that their leadership is only for a limited time, and that their duty is to follow Jesus' example. ${ }^{82}$ The greatest is the servant and greatness is found in service. The world (and the church) is full of people who play political games, either by manipulating people or policies and selectively using principles. Trust in God and the acceptance of human powerlessness are required to resist the temptation to use politics to preserve power. The development and success of the medical work in the Seventh-day Adventist church after Kellogg's departure confirms the fact that no person is essential for the progress of the work. ${ }^{83}$

In his letter to Daniells, W. C. White quoted his mother Ellen: "Prolonged power will tempt any man to consider his wisdom superior." ${ }^{84}$ Practical solutions to this problem such as limiting leaders' time in office, assigning regular mandatory changes in

\footnotetext{
${ }^{82}$ Benjamin McArthur, "A. G. Daniells and Lessons of Leadership," 11.

${ }^{83}$ Ibid., 10.

${ }^{84}$ Quoted in Benjamin McArthur, A.G. Daniells: Shaper of Twentieth-Century Adventism, 322. from Letter W. C. White to A. G. Daniells, June 20, 1910, Ellen G. White Estate Branch
} Office Document File. 
leadership, clearly defining mandates within the limits of power, and educating leaders about the extent of their responsibilities and position of power. Some of these suggestions have a downside. While limiting the time of leaders' tenure would probably make leaving the office much easier and cease some power struggles, insisting on change is not always the best solution. No suggestion or policy can be more effective than one's personal decision to follow Jesus' example and practice his humility.

Abuses Related to the Misconduct of a Leader

The abuses discussed in the previous section dealt with leadership's misguided focus on the preservation of power. Abuses in this section are related to the misconduct of the leader.

\section{Basic Premise}

The conduct of a leader is either teleological or deontological in nature. It is determined by either the consequences of his/her actions or decisions or by a moral obligation to do what is right. Both approaches, deontological and teleological, have the potential for abuse. When leaders attempt to achieve good goals through bad methods, they are abusing their power. And when leaders attempt to uphold principles and do what is right, but arbitrarily apply norms without considering how such actions will affect others they again are abusing their power.

\section{Pattern for Analysis}

In this section the study of Daniells' and Kellogg's leadership behavior will look at possible abuses of power related to their misconduct. Did they use inappropriate conduct to achieve good outcomes? Did they apply norms arbitrarily and carelessly? 


\section{Analysis}

The two leaders can be categorized as follows: Kellogg mostly evinced a utilitarian leadership style; Daniells' leadership style was more deontological. Therefore, while discussing their abuses related to their misconduct, each one will be reviewed by their different ethical emphasis.

Daniells was a man of convictions and principle. He believed that he needed to follow his convictions and do what is right. But, he also believed that he had the authority to persuade his followers to do what he thought was right. As was previously noted, the influence of the burden of responsibility will be further analyzed in the section on abuses related to misplaced responsibility, authenticity, and presence; however, it may be noted here that it was a determining factor in his misconduct. It was the reason behind his strict behavior in his personal and professional life. That strictness can be morally justified by appealing to principle, but a lack of compassion and narrow-mindedness in its application were abuses of power. This is how principle-based leadership becomes kingly power.

Valentine pointed out that Daniells properly understood the responsibility of leadership to manage the right and proper use of resources, to secure "the long-term viability of a church enterprise" and not to waste church money. ${ }^{85}$ But Daniells struggled with being flexible when "regular policies and practices would just not fit." 86 Consequently, he was inflexible and unwilling to change his opinions. ${ }^{87}$ That type of leadership led to an abusive system that was out of balance, where only the leader was

${ }^{85}$ Gilbert M. Valentine, The Prophet and the Presidents, 230.

${ }^{86}$ Ibid.

${ }^{87}$ John J. Robertson, A. G. Daniells: The Making of a General Conference President, 1901, 60. 
right and allowed to do whatever he/she wanted. That system can be easily preoccupied with errors and finding blame, as well as focused only on achievements that try to achieve unreasonable standards. While following and upholding principle is desirable, who applies them and determines what they are is important as well.

A good example of this was Daniells' inability to accept personal criticism regarding him or his work. He received reproof from E. G. White for affirming humility but not practicing it as the president of the conference. ${ }^{88}$ An inordinate emphasis on upholding principle often results in double standards, which are usually covered in secrecy. Daniells wanted to avoid the traps of secrecy. Valentine points out that many of his actions were the result of personal testimonies and private correspondences, and members of the church were not aware of the real reasons for his actions. ${ }^{89}$ Daniells himself wished for more transparency. ${ }^{90}$ He was aware that so many abuses of power happen because of lack of transparency, which opens the door for manipulation. Even when everything is done correctly, there can be suspicions about what is going on behind the scenes. This can cause accusations of power abuse. Nevertheless, protecting the privacy and integrity of persons involved in an issue often requires privately dealing with the problem. That also raises the question of trust in leadership, and is it partial transparency better in certain situations. A simple answer would be: it depends on the situation. But this answer potentially opens a Pandora's Box of excuses for power abuse.

${ }^{88}$ Ibid.

${ }^{89}$ Gilbert M. Valentine, The Prophet and the Presidents, 223.

${ }^{90}$ Daniells wrote in 1903 to W. C. White: "from the time I received that communication until this hour, I have felt that the light given in these communications ought to be given freely to whole denomination." Quoted from: ibid. 
Although Daniells sought to uphold his principles, he was also abusing his power by being controlling. Nevertheless, the strongest leaders, such as Daniells and Kellogg, are usually the most efficient leaders. They do not always employ the best methods, but they produce the most effective results. It is not surprising that Plato, in his Republic, concluded that the worst governing system is a democracy (the rule of people - when everybody rules it finishes in chaos), and the best would be a benevolent autocracy. ${ }^{91}$ In a way, that aligns with the biblical worldview in which all Christians follow God, who is an all-powerful but loving ruler of the universe. But when humans attempt to assume his role and his place they always abuse their power.

While Daniells' strictness was based on his conviction of the necessity to do what is right, Kellogg was obsessed with making an impact on the world. His goal was not only to heal people but also to help them stay well. In addition to medical care, he also showed compassion for the needs of the less fortunate and organized practical help for orphans, the elderly, and the poor. As Schwarz pointed out: "The doctor believed that the true purpose of education was 'to make useful, noble men and women, not simply scholars. $", 92$ It is easy to criticize Kellogg, but behind many cases of his abuses of power were so often his desires to accomplish very noble and good intentions. Unfortunately, some of his weaknesses diminished his great achievements. Those weaknesses related to his personal character traits will be discussed in the following section. Ultimately, he abused his power in his pursuit to make the world a healthier and better place.

\footnotetext{
${ }^{91}$ Plato, The Republic.
}

${ }^{92}$ Richard W. Schwarz, "John Harvey Kellogg: American Health Reformer," 214; John Harvey Kellogg, "True Education," Good Health, January, 1889, 16. 
Kellogg seemed to be aware of his weaknesses; it appears that he tried to overcome them, but he wasn't completely successful. He wrote to G. I. Butler: "I am fully persuaded that this work ought not to center around me." ${ }^{\text {"93 }}$ Unfortunately, knowing somebody's weaknesses and even admitting them might not be enough.

The list of Kellogg's abuses related to his misconduct in his pursuit of health reform includes some already mentioned. He was very judgmental of those who did not practice strict vegetarianism. He even used "out-loud shaming"94 in his institution to impose the health reform on his fellow Seventh-day Adventists. He eagerly attacked and removed his opposition, and he was almost always in conflict with one or another church leader. While some of them obstructed him from achieving his goal, it is hard to imagine that all of them were always wrong and Kellogg was always right. Some of the arguments were caused by real problems. For example, he was unhappy with the way church money was distributed, and he believed that many of the pastors who entered the ministry did so just for the money. While his argument might have some truth to it, he was not in charge of the church's money, and he only used that argument as leverage for his negotiations concerning the financing of his project or to put down other church activities so as to endorse his own. Schwarz explained: "Although available evidence makes it difficult to evaluate all of Kellogg's complaints against Adventist preachers, it seems reasonable to suspect that some were justified, at least in part. Significantly, as he became embittered

\footnotetext{
${ }^{93}$ Richard W. Schwarz, "John Harvey Kellogg: American Health Reformer," 72; Letter J. H. Kellogg to G. I. Butler, December 21, 1902, MSU Kellogg Papers.

${ }^{94}$ Term used by Johnson and VanVonderen to describe abuse of power by shaming somebody to make him/her to comply with the leaders requirements. (David Johnson and Jeffrey VanVonderen, The Subtle Power of Spiritual Abuse, 56.)
} 
against ministry, he disparaged them 'in every way that he could' and adopted toward them an 'autocratic, arrogant and haughty' manner"95

But one of the clearest examples of his misconduct was when he co-opted the church's institution as his own endeavor. The Institute, and later the Sanitarium, orphanage, home for elderly, and his medical and humanitarian mission in Chicago were treated as his property. In the case of the Sanitarium, he became the majority stockholder. Nevertheless, all those institutions started as church-owned and managed institutions that he took from the church. He used manipulation, political maneuvering, and excessive use of power (kingly power) to do so. His pride, which was based on his talent and achievements, cannot be denied, but one striking thing is that he was doing all of it in order to achieve a noble goal.

Kellogg would only cooperate with other church leaders if they accepted his actions and policies to change the world for the better. Kellogg was a perfectionist and he wanted to see results. He saw the pastors as obstacles to health reform and the medical work. They lacked education so he felt superior to them. He did not seem as if he wanted to be separated from the church, but rather it was what he had to do to remove the brakes from the progress he planned. Even the non-denominational status of the Sanitarium, which he introduced, served as an opportunity to receive additional nondenominational resources for his extended endeavors, which the church was not financially capable of supporting. The refusal of Chicago's non-Adventist philanthropists and donors to support

\footnotetext{
${ }^{95}$ Richard W. Schwarz, "The Kellogg Schism - The Hidden Issues," 26.
} 
his mission in Chicago because of his association with the church probably affected his feeling that this would be the right way to go. ${ }^{96}$

It can be observed that his obsession with the final goal lead to his disregard for some loyalties and principles, and his carelessness concerning method. He assumed that the goal justifies the means. All of this leads to the abuse of power. When this is joined with the wish for control and a feeling of pride and superiority, the abuse of power is unavoidable. Like king Solomon, Kellogg's talents, gifts and capabilities became, at the end, food for his abuses.

\section{Lessons Learned}

While it appears that pragmatism in the decision-making process depends on the situation, it also may open the door for double standards and consequently the abuse of power. In addition, indiscriminately applying principles and ignoring the uniqueness of each situation can result in abuses of power too. Extreme strictness in applying power is also the food for power abuse. Upholding principles in a Christian setting is desirable, but flexibility and moderation in their application will lower the chance of power abuse. Leaders need a balanced approach. They have to envision desirable goals, but in the process of achieving their goals they need to reject the use of any inappropriate method. They also need to uphold principles, but in their application they need to show care, understanding and flexibility.

\footnotetext{
${ }^{96}$ See: Albert Dittes, Three Adventist Titans: The Significance of Heeding or Rejecting the Counsel of Ellen White; Richard W. Schwarz, "John Harvey Kellogg: American Health Reformer."; Richard W. Schwarz, "The Kellogg Schism - The Hidden Issues."; Gilbert M. Valentine, The Prophet and the Presidents.
} 
This is probably the reason why leadership should not be concentrated in one human leader or a small body, which would be easy to control. In "a multitude of counselors there is safety" (Proverbs 24:6), and extreme stances and abuses could be prevented if responsibility were shared among leaders instead of concentrated in any one person. Additionally, the balance of deontology and utilitarianism is necessary for the balanced leadership.

\section{Abuses Related to Corrupted Character Traits}

Closely related to the conduct of a leader is the character of the leader, which is supposed to reflect the leader's Christian values. G. I. Butler, in his speech at the 1903 session of the GC, asserted that the election of the president of the GC is not a problem by itself because leadership depends on the heart of the elected person. While that comment demonstrates support for organizational structure, Butler was right that leadership style depends on the character and attitude of a leader more than organizational structure..$^{97}$

\section{Basic Premise}

The character of a Christian leader is very important in Christian leadership. Christian leaders are imitators of Jesus' example and so they are to lead by displaying this example to their followers. That makes it necessary that every Christian leader should practice and exemplify the Christian virtues. Those virtues are supposed to be the basis of all practical Christianity. Leaders who ignore those virtues or are corrupted by vices abuse their power.

\footnotetext{
97"The General Conference Bulletin: Thirty-Fifth Session," 163.
} 


\section{Pattern for Analysis}

This analysis of Daniells' and Kellogg's leadership will look at the traits of character that negatively affected their leadership. We will attempt to determine how those vices negatively affected their leadership.

\section{Analysis}

While both Kellogg and Daniells had many talents and great leadership qualities, this study concentrates on their weaknesses - the traits of character that caused them to abuse their power. Some of those characteristics might be morally neutral but the way they were applied might have resulted in abuse.

Daniells can be described as stubborn and determined, or just persistent.

Stubbornness and persistence are two words that describe the same character trait but that reflect the observer's perception of that quality. According to Robertson, both Daniells' stubbornness and determination were caused by his personality and inner motivation. ${ }^{98}$ By using stubbornness Robertson implies that the President's use of his inner energy/motivation exceeded the necessary power to achieve the goal, and that he was not ready to give up when the situation required it.

In 1877 while he was still young, Daniells was wrestling with the conflict between his speech impediment (limitation) and his conviction of his spiritual call. He promised God that he would follow his conviction completely. Consequently, he became very persistent and stuck with his convictions vigorously. Some of his later reactions might be the result of this experience, which included the conviction that he had

${ }^{98}$ John J. Robertson, A. G. Daniells: The Making of a General Conference President, 1901, 57. 
answered God's call and only did what God wanted him to do. His perception that he received God's guidance and accepted his call probably informed his perception that he was right and that he needed to defend the principles God revealed to his church. On the other hand, his personal weakness, his speech impediment, did not determine his leadership capability but rather helped him to work harder to overcome it and to achieve more. $^{99}$

It was hard to persuade Daniells of anything else once he was firmly settled in his convictions, ${ }^{100}$ and would follow them with his whole heart. Daniells was "either all against or all for a thing." 101 A good example is his dealing with issue of establishing the church educational institution in Australia. In late 1890s Daniells decided as conference president he would hinder the construction of the school at Avondale for two years. In spite of Ellen White's strong support for establishing a school there, he did not see that place as the right choice. But when, after two years, he was morally convicted that this was the right thing to do, he vigorously worked on raising funds and supporting the school. $^{102}$

This "all against or all for" trait was exemplified in his work as an administrator. It was also the central cause for his abuse of power. His mandate was not to make all decisions, his position did not make him always right, and he was not placed in the position of president to think for his brethren. Also, he was not voted president because

${ }^{99}$ Ibid., 15.

${ }^{100}$ Richard W. Schwarz, "John Harvey Kellogg: American Health Reformer," 394.

${ }^{101}$ John J. Robertson, A. G. Daniells: The Making of a General Conference President, 1901,81 .

${ }^{102}$ Ibid., 60. 
he was righter than others. But his firm conviction shaped his leadership. It seems that the only person who was able to affect his opinions significantly was Ellen White, and this was only because of his conviction that she possessed the prophetic gift.

Another trait of his character affected his service even more. He did not when how to stop working, and he overworked himself just like Kellogg. That affected his health, he became overburdened and exploited, and this brought on a deep depression. ${ }^{103}$ While successful leaders have to work hard and put a lot of effort into his/her service, consistently overworking can be detrimental for the leader and offer a negative example. Spiritual leaders often swing from one extreme to the other. Either they put all their time into working for the church and neglect their marriages, families and health, or they neglect their call and work, without any attempt at sacrifice and effort. A balanced approach is the only right solution.

But some other traits of character are completely detrimental for Christian leadership. From many of the examples already mentioned it could be observed that Daniells had a high opinion about his own judgments. While he was willing to admit his mistakes, Daniells did not question himself. The result was that Daniells himself admitted his character flaw - he stated that he had a "tendency to dominate over my brethren;" and this was also known in the church. ${ }^{104}$ This self-confidence created in him a feeling of irreplaceability, so he was driven to do everything. ${ }^{105}$ When Christian leaders do everything by themselves they put themselves in a position of power and authority that

${ }^{103}$ Ibid., 56.

${ }^{104}$ Benjamin McArthur, "A. G. Daniells and Lessons of Leadership," 8.

${ }^{105}$ John J. Robertson, A. G. Daniells: The Making of a General Conference President, 1901, 57. 
challenges God's authority and, at the same time, prevents others from properly utilizing their spiritual gifts and participating in the mission and mandate they received from God. Robertson states that Daniells did not trust the work of others and was dissatisfied with their engagement in the church's endeavors. ${ }^{106}$ It seems that he did not realize that his micromanagement contributed to the situation. Also, his lack of flexibility did not encourage others to participate in ministry. All of this led to Daniells adhering to a double standard and to his strict conformity to the rules.

One of the problems is that it is hard for a leader who abused his power to admit to it or to even realize that abuse occurred. Leaders usually try to justify their own abuses or to interpret them in positive terms. For example, Butler, former president of the GC (1871-1874 \& 1880-1888), in his speech at the 1903 session of the GC, said that he failed to see anything of "kingly power" in his 13 years of presidency as well as in James White's leadership. While technically he was right because the term was not used at the time, both leaders were autocratic and Ellen White reproved Butler's authoritarian leadership. ${ }^{107}$

Daniells needed the outside testimony of persons in authority to make him aware of these matters and to help him control some of his vices. After receiving reproof, Daniells became mindful of the problems and attempted to fix or at list to control many of them.

\section{${ }^{106}$ Ibid., 56.}

107"The General Conference Bulletin: Thirty-Fifth Session," 163. See: (Letter 21 - E. G. White to G. I. Butler, October 14, 1888, Ellen G. White Estate Branch Office Document File; Letter 12 - E. G. White to O. A. Olsen, October 28, 1885, Ellen G. White Estate Branch Office Document File.) 
Kellogg is a good example of another person challenged with similar characteristics. Many great qualities can be used and misused as well. In describing Kellogg one of his associates said that he had a hypnotic influence. His associates obeyed his instructions even when they disagreed with him. ${ }^{108}$ That power of influence is what every leader wants - to be able to influence others for action. Unfortunately, many charismatic leaders abuse their power with their charismatic personality. They have the ability to influence and even manipulate their followers, but they do not use that power appropriately to influence their subordinates to do good; instead they used them and abused their power to fulfill their own agenda.

Kellogg was personally known for wearing a white wardrobe. His explanation was that white clothes are healthier, that they allow the sun's ultra-violet rays to penetrate and kill harmful germs. While care for somebody's appearance by itself is not negative, in his case it seems that it was a part of a pattern of self-presentation. Some thought that his white wardrobe was an example of his showmanship. ${ }^{109}$ Additionally, E. G. White criticized him for perpetually expanding the Sanitarium and for creating an atmosphere similar to that of a "grand hotel." 110 While enlarging the size of the institution might be the result of increased needs, the atmosphere in the institution was a reflection of an attempt to create a name (image) for the institution. Also, if more prominent people visited the Sanitarium and if the Sanitarium grew bigger, Kellogg would ultimately receive the credit. This points to Kellogg's tendency to show off. That was one of his

\footnotetext{
${ }^{108}$ Richard W. Schwarz, "John Harvey Kellogg: American Health Reformer," 80.

${ }^{109}$ Ibid., 61.

${ }^{110}$ See: ibid., 182-183.
} 
character traits. While a positive image is part of effective leadership, Christian leaders are not supposed to publicly parade their accomplishments, but rather to be humble representatives of their leader - Jesus.

Kellogg's father observed that his son also tended to be headstrong and selfwilled and before he died he asked E. G. White to influence his son to control those traits of character. Through the years he asked Kellogg to control his ambition and not to take too much personal credit for the success of the work in which he was engaged. He personally admitted these reproofs were justified. ${ }^{111}$ In addition, Kellogg had a strong desire for recognition, which was probably the result of feeling unappreciated. ${ }^{112} \mathrm{He}$ wrote to James White three years after he took over the Sanitarium that there were so many difficulties in his work, that he felt that he would work himself to death, but "no one will thank me for it."113

On the other hand, it seems that Kellogg was personally aware of his weaknesses. He admitted to his selfish pride and his inclination to be big-headed, hasty, suspicious, stubborn, irritable, hypersensitive, morbidly fretful, narrow-minded, strong willed, pugnacious, controversial and skeptical. ${ }^{114}$ While he tried very hard to overcome his weaknesses, they caused so many problems for him personally and it led to the unfortunate separation of the Battle Creek Sanitarium from the church, Also, his personality affected the medical missionary work of the church. Finally, division

${ }^{111}$ Ibid., 69.

${ }^{112}$ Ibid.

${ }^{113}$ Quoted from: ibid., 73.

${ }^{114}$ Ibid., 75. 
developed among the members regarding Kellogg's behavior. All these consequences were too high a price for the expertise of such a prominent church leader. In the end, he was overcome by his vices. Most likely as a result of his spiritual failure to let God change his heart, and with his divine power, overcome his personal weaknesses (Ezek 11:19 NKJ). Change of character requires the supernatural power of God.

\section{Lessons Learned}

Christian leadership requires the leaders to uphold the highest standards of Christianity and to practice them. Those leaders are supposed to nurture the best traits of character and endorse Christian virtues. Failure to do so, and even letting frailties control their lives represents the failure of leadership and consequently abuse of power.

Awareness of personal weaknesses and bad character traits is the first step of dealing with those abuses. Endorsing and practicing positive traits of character is a good step in the right direction. Nevertheless, dealing with somebody's vices and deficiencies belongs to the spiritual realm and requires the change produced by God's intervention in somebody's life.

Abuses Related to Ignoring Christian Principles

Principle-centered leadership is part of ethical leadership and it is a call for leaders to follow "true north" principles. Christian leaders are to follow and practice the highest standards and principles of Christianity.

\section{Basic Premise}

For Christian leaders, following "true north" principles mean to follow biblical teachings and the example of Jesus Christ. Although further definition of those principles 
would require another study, it can be agreed that Christian leaders have to live according to the principles they preach and endorse. Ignoring these principles, not practicing them, and having double standards is abuse of power.

\section{Pattern for Analysis}

This section attempts to determine whether Kellogg and Daniells followed "true north" principles. The basic question is: Did they practice what they preached?

\section{Analysis}

We already documented some of Kellogg's double standards. For example, he showed concern and care for the less fortunate, but he exploited his employees by capitalizing on their commitment to the church so that he could reduce costs. He also strictly required that pastors follow and accept the church's health reforms while he was not obligated to do so. It seems that for him his "true north principles" were health reform and the progress of his endeavors. However, since he was a member of the Seventh-day Adventist Church, and claimed to accept the corresponding experience of faith, it is also necessary to evaluate Kellogg according to the principles of the church. Therefore, according to this criterion, it is possible to detect in the years preceding his separation from the church a failure to endorse its teachings and beliefs. This is evinced by his introduction of some pantheistic ideas that were antithetical to church doctrine. On the other hand, except for those ideas, his conflict with the pastors and leaders of the church, and questions on the prophetic authority of Ellen White, Kellogg never renounced his Adventist faith. It is true that he applied some of those beliefs (such as how to properly keep the Sabbath) more loosely than other Adventists of that time, and that he insisted on the non-denominational and later non-Adventist status of the health institution, but he did 
not denounce all the teachings of the church nor reject church practice. Yet, Kellogg's claims and professions in support of the church's endeavors were in conflict with his practice. He used any available source for the furtherance of his work without regard for its effect on other parts of the church and its mission. ${ }^{115}$

A. G. Daniells served the church all his life. He endorsed the teachings of the church, as well. However, Kellogg accused Daniells of not keeping all the principles of health reform, namely, he was not a strict vegetarian. Additionally, during his conflict with Kellogg, Daniells was abusive toward his subordinates who did not side with him in this conflict. It has been mentioned that during this time Ellen White warned Daniells about overstepping his authority. But Daniells did not modify his actions because of his conviction that his job was to protect and manage the church. Therefore, in 1907 Mrs. White wrote to Daniells and Evans and stated that, "a great mistake has been made in the exercise of human authority in God's work." 116 This letter suggests that Daniells' actions did not coincide with the principles of Christian leadership. ${ }^{117}$

Preaching the principles but not practicing them may also be viewed as an abuse of power. In 1910 Ellen White refused to meet with Daniells at her home in Elmshaven because he did not put into practice what he was preaching. As the President of the GC he endorsed the missionary work in densely populated cities in the United States verbally, but almost nothing was done in practice. After his Elmshaven visit Daniells made a much

${ }^{115}$ Gilbert M. Valentine, The Prophet and the Presidents, 224.

${ }^{116}$ Ellen White, Manuscript Releases: From the Files of the Letters and Manuscripts, vol. 8 (Washington, D.C.: E. G. White Estate, 1990), 203.

${ }^{117}$ See: Gilbert M. Valentine, The Prophet and the Presidents, 276. 
stronger case for the mission work. In addition, he also worked personally as a missionary on the streets of New York. It seems that Ellen White's reprimand brought positive changes to his behavior and persuaded him to put his preaching into practice. ${ }^{118}$

\section{Lessons Learned}

Preaching principles without practicing them jeopardizes a leader's authority in the church. Also, having double standards is morally wrong and is an abuse of power. No leader is above the law. But extreme strictness in applying principles or using them as a political weapon is an abuse of power too. To prevent those abuses leaders need clear principles, and they need to be required to practice them. Their subordinates and peers need to remind them of those principles.

Abuses Related to Misplaced Responsibility, Authenticity and Presence

While the previous section dealt with the issue of principles in leadership, this one will analyze abuses of power related to wrongly applied elements of ethical leadership.

\section{Basic Premise}

Three components of ethical leadership are responsibility, authenticity, and presence. Christian leaders should reflect all of them in their leadership. While all three are important, this study focuses on responsibility. It was already pointed out that many abuses of power are related to a leader's sense of responsibility. When a leader's perception of responsibility results in actions that are not justified by the leader's position of authority and his mandate, abuse of power may result.

${ }^{118}$ Ibid., 288-291. 


\section{Pattern for Analysis}

This section observes how the elements of ethical leadership - responsibility, authenticity and presence - affected Daniells' and Kellogg's leadership. It will also look at how their feeling of authenticity, presence, and particularly responsibility contributed to abuses of power.

\section{Analysis}

J. H. Kellogg's leadership style was a combination of two impulses, namely to help the sick and less fortunate and to become famous. He simultaneously overworked himself and controlled those around him. He was a progressive medical doctor, a genius, an inventor and an eccentric all in one. Kellogg cared deeply for people, but he also used them and required their unquestioning obedience. His unique personality, which was a mixture of both good and bad characteristics, is a good example of the fact that ethical leadership, as well as all ethical systems, has its strengths and weaknesses. They are simply a human attempt to describe in human words complex ethical issues. In terms of ethical leadership, Christian leaders are supposed to demonstrate the positive, good side of these qualities.

Kellogg's presence in the church was very significant. For almost fifty years he was a member of the Seventh-day Adventist Church, and thirty of those years were spent in a leadership position. He held also a ministerial license from the denomination. ${ }^{119}$ After 1907 when he was disfellowshiped he never publicly rejected the teachings of the church, but he had many disagreements with the church administration. Sometimes he

${ }^{119}$ Richard W. Schwarz, "John Harvey Kellogg: American Health Reformer," 65.] 
questioned the prophetic authority of E G. White and sometimes he endorsed it. It seems that he accepted it when it supported his positions, which was a reflection of his pragmatism. Kellogg generally used his presence to benefit the church, but he also used it to advance his personal agenda. Basically, he used his presence to support his cause and ideas. In that way Kellogg abused his presence as a leader.

At the same time there is the issue of authenticity in his membership in the church and in his attitude toward the church. Was he just a nominal Adventist? The church was the organization that gave him the opportunity to develop his medical and humanitarian work. It is true that Ellen White, after the 1888 GC session, claimed that he was a converted man, at least for the time being. And it would be unfair to claim that he was not an Adventist. But when he stopped believing in certain church beliefs, would it not have been right to say it openly? If he continued to pretend to be an Adventist out of convenience, which is the implication of his statement that he had expected the institution to separate from the church, then that would be an abuse of power related to dishonesty. It could also be an example of inauthenticity. So, it appears that some of Kellogg's actions sometimes lacked integrity.

His lack of integrity is also evident in his brother Will's insightful remark. He said that J. H. Kellogg sometimes remembered things that never happened. That corresponds with some claims that he sometimes, although unconsciously, distorted the truth and used the distortion to support his ideas. While memory by itself can be distorted and no two people can recall an event in the same way, if a leader is twisting the truth to 
achieve his/her goals, regardless of their noble intentions, that presents an abuse of power. ${ }^{120}$

Six months after he became leader of the Institute, there were suggestions of hiring his half-brother Merritt to supervise his work. It was suggested that he would give him administrative support and assistance. But Kellogg's response was that even with the aid of Merritt to take some of the responsibility, he would still feel responsible for the whole work. ${ }^{121}$ That feeling of responsibility prevented him from sharing power with another and made him attempt to remove all competition. He would do whatever was necessary to advance his work. This feeling of responsibility is a sign of good leadership and irresponsibility is contrary to the nature of Christian leadership. However, when leaders feel responsible for the wrong reasons and believe that they have to do everything because nobody can do their job, they start to abuse their power. We already pointed out that Kellogg believed that he was the only one who could do the work correctly, that only his way was right. Yet, he did not put any effort into developing useful helpers and he removed any potential competitors. Even though he was putting a lot into the medical work, he never let anybody to outshine him.

Daniells did not have any questions regarding his Adventist beliefs (except with some health reform issues), and he was present in the life of the church. However, he struggled with the issue of responsibility. Daniells' view on responsibility can be observed in his strict emphasis on organization. He was acting from the position that

\footnotetext{
${ }^{120}$ Ibid.

${ }^{121}$ Ibid., 70.
} 
people in charge had to control others because they have the responsibility to make sure that everybody works efficiently and responsibly. ${ }^{122}$ While in business micromanagement is good and necessary, it might be inappropriate for spiritual leadership.

The feeling of responsibility is a necessary quality of good leadership. In his letter to W. C. White in December 1903, Daniells wrote: "[I am] Filled with a terrible sense of responsibilities resting upon me. I promised the Lord with all my heart that I would be true to this cause, and do all in my power to prevent anything from arising in this denomination to dim the glory of this gift, and of the Lord's servant who had exercised this gift so many year."123 It is obvious from his statement that Daniells considered it his duty to protect the church and the church's prophet. Additionally, he was ready to stand and protect the principles he believed in. Describing his struggle with Kellogg in 1903, he was aware of possible personal consequences (to be removed from his position of leadership), but he decided to follow his convictions. ${ }^{124}$ Do we not expect every good leader to stand for his organization and its principles? Is this not the responsibility of every good leader?

The problem is not in the feeling of being responsible. That feeling is a requirement for leadership. However, improperly applied feelings of responsibility can be detrimental to the quality of leadership. Problems arise when a leader incorrectly understands his/her mandate and consequently uses improper methods, all justified by

\footnotetext{
${ }^{122}$ Albert Dittes, Three Adventist Titans: The Significance of Heeding or Rejecting the Counsel of Ellen White, 49.

${ }^{123}$ Quoted from: Gilbert M. Valentine, The Prophet and the Presidents, 243.

${ }^{124}$ See: ibid., 242.
} 
his/her responsibility. Subsequently, the leader will overstep his/her authority. In a letter to E. R. Palmer and Daniells from January 1903, Ellen White asserted that "to no man has been assigned the work of interfering with the work of one of his fellow laborers." ${ }^{125}$ Valentine explained that according to White, "Daniells had not been 'appointed the work of being overseer of his fellow men. Every man is to bear his own burden.'" ${ }^{126}$ While Daniells' feeling of responsibility is extremely important for a good leader, his misunderstanding of the limits of his responsibility led him to overstep the boundaries of his authority. He tried to control others and impose the principles he believed in. It is not surprising that this tendency resulted in A. T. Jones identifying Daniells as the problem in the ongoing dispute between the two branches of the church in $1903 .{ }^{127}$ Kellogg made similar claims in his already quoted accusation that Daniells was plotting to become "ruler over Israel." 128 While Daniells can be credited for being, theologically and in principle, on the more orthodox side of the dispute, it seems that his leadership methods were no different from those used by Kellogg. Although Kellogg was absolute ruler in his branch of the work, Daniells was an autocratic leader of the whole denomination. The fact that his leadership was partially shaped by his reaction to Kellogg's domineering approach does not justify his approach.

In Daniells' case his feelings of indispensability and responsibility were factors in his attempt to preserve his power. He was always willing to accept another term, even

\footnotetext{
${ }^{125}$ Quoted from: ibid., 237.

${ }^{126}$ Ibid.

${ }^{127}$ Ibid., 261.

${ }^{128}$ Ibid., 244.
} 
though he repeatedly complained of being tired and weary and of wishing to step down. Before the 1922 session of the GC, his wife claimed that he would step down if a qualified candidate could be found. ${ }^{129}$

Whenever a leader's feeling of responsibility is not correctly informed concerning the limits of that responsibility and which methods can and should be employed inside those limits, the result is the abuse of power. Christian leaders need to know that their responsibility is not to do God's job and replace Him in the executive position. It seems that this distorted feeling of responsibility is too often the cause of power abuses. It can also serve as the leader's excuse for abuses of power.

\section{Lessons Learned}

All elements of ethical leadership have their place in Christian leadership. Christian leaders are to be responsible, authentic, and present. Their inappropriate application can contribute to the misuse of power. Out of the three elements of leadership, responsibility is probably the most complex. While it is not right to ignore a leaders' responsibility, taking responsibility for something that is not under the purview of a leader's responsibility is an abuse of power. Christian leaders can feel responsible for the work that is supposed to be done by God or by their fellow believers. Ultimately, their responsibility is limited by their mandate and authority delegated to them by the church.

In order to prevent abuses of power related to misplaced responsibility, authenticity, and presence, Christian leaders must be educated about the importance of each element. They should know that it is important to be authentic and present and to

${ }^{129}$ Benjamin McArthur, "A. G. Daniells and Lessons of Leadership," 10-11. 
have integrity. Also, it is necessary to uphold the highest moral standards and principles. They also have to know clearly the nature and limits of their responsibility. Those limits are expressed in the limits of their authority - they are servants of the Lord and in service to the people around them. They must wholeheartedly fulfill their responsibility, but restrain themselves from taking on the responsibilities of God or their subordinates. Sharing responsibility with others is one of the preventative measures for abuses related to responsibility. It requires trust and a leap of faith, but leaders in charge are not the only ones with responsibility. It is important that their subordinates keep them accountable for their use of power.

\section{Abuses of Power in Light of the Principles of Christian Servant Leadership}

All of the previously mentioned abuses of power we analyzed are the result of leaders failing to follow the principles of Christian servant leadership. ${ }^{130}$ One of the challenges for an analysis of the leaders in this study is that the current concept of servanthood appears to be different from concepts of leadership at the turn of the $20^{\text {th }}$ century. Additionally, in the last third of the $20^{\text {th }}$ century, modern concepts were influenced by scholarly and secular ideas.

Neither the current view of the church and its organization nor the views of Adventists at the turn of the $20^{\text {th }}$ century are perfect. They were only presented as a reference to better understand the behavior of leaders and to offer a contemporary context for church leadership. Those views help us analyze the leaders of the past and to find possible applications for today's leadership. In the second chapter this study proposed a

\footnotetext{
${ }^{130}$ The term is suggested by this study as a proposed ideal leadership model.
} 
supposedly ideal model of leadership that is also imperfect. While it reflects current understanding of ideal Christian leadership, it strives to transcend the time-conditioned nature of contemporary views on leadership. Nevertheless, in its essence, it is only a starting point for further discussion in the discourse on Christian leadership, and it is used as an essential reference for discussing the morality of the leaders in this study.

Although social science did not use the same leadership terminology during the time of the pioneers and their leadership practice suggests a lack of understanding of an appropriate leadership model, it seems that, at least in theory, the leaders we analyzed would agree with the basic ideas of the proposed Christian leadership model.

There are examples that indicate an awareness of a need to practice a form of leadership equivalent to the proposed Christian servant leadership model. In his discussion on the 1903 session of the GC, McArthur asserts that church leadership practice was shaped by a need for more centralized and autocratic governance in the $20^{\text {th }}$ century that was similar to the United States' government's need to have a more centralized and autocratic leadership to unite the country. ${ }^{131}$ In spite of that need, W. C. White presented, in his response to the minority report regarding the title of the president of the GC, an understanding of servanthood not always applied in the church's practice:

I do not think that there is very much in a name. When you say that your president shall act as "chairman," that his duties are to act as chairman, I understand it is simply putting the business where he can use the title usually carried by such a position; and when we specify distinctly that his duty shall be to act as chairman of the committee, and he shall do as the committee advises, we make him the servant of the committee. He is not a king, but a servant; and I pray God that he shall be a faithful servant, who shall not attempt to use kingly power. ${ }^{132}$

\footnotetext{
${ }^{131}$ Benjamin McArthur, A.G. Daniells: Shaper of Twentieth-Century Adventism, 180.

132"The General Conference Bulletin: Thirty-Fifth Session," 158.
} 
W. C. White clearly presented the president of the GC as the servant of the committee and consequently of the church.

Ellen White's statements on leadership roles are also in agreement with the ideas of Christian servant leadership. She wrote that a leader should be an example but must not be oppressive and should not have power over an individual's conscience. ${ }^{133}$ Based on the equality of all believers, she pointed out that no leader has the right to rule, and in the case of such an attempt that leader must be removed. ${ }^{134}$ She further proposed that "ruling over" another is detrimental for Christian leadership and leaders have to share responsibility with their subordinates. ${ }^{135}$

McArthur also noticed that in the time of the pioneers, "Adventist culture assiduously sought to avoid anything resembling competition within its own ranks." ${ }^{136}$

133“'You are to be an example to your brethren, worthy of imitation. Your words, your spirit, your deportment, even the manner in which you treat your brethren are sowing seeds for good or evil... Let no man feel that his position as president either of the General Conference or of a state conference clothes him with a power over the consciences of others that is the least degree oppressive, for God will not sanction anything of this kind. He must respect the rights of all, and all the more because he is in a position where others will pattern after him." (Letter 21 E. G. White to G. I. Butler, October 14, 1888.)

1346"The spirit of domination is extending to the presidents of our conferences. If a man is sanguine of his own powers and seeks to exercise dominion over his brethren, feeling that he is invested with authority to make his will the ruling power, the best and only safe course is to remove him, lest great harm be done, and he lose his own soul, and imperil the souls of others. 'All ye are brethren."' (Letter 55 - E. G. White to O. A. Olsen, September 19, 1895, Ellen G. White Estate Branch Office Document File.)

135"I have been shown that there is one practice which those in responsible places should avoid; for it is detrimental to the work of God. Men in position should not lord it over God's heritage and command everything around them... Our leading brethren have made a great mistake in marking out all the directions that the workers should follow, and this has resulted in deficiency, in a lack of the care-taking spirit in the workers because they have relied upon others to do all their planning, and have themselves taken no responsibility. (Letter 12 - E. G. White to O. A. Olsen, October 28, 1885.)

${ }^{136}$ Benjamin McArthur, A.G. Daniells: Shaper of Twentieth-Century Adventism, 143. 
Applying that culture to leadership is an affirmation of the priesthood of all believers and the equality of all members. That is also an affirmation of the principles of Christian servant leadership, which proclaim that leaders are not rulers but in service to the people and to the Lord.

Although the abuses of power were affected by a leader's understanding (or misunderstanding), they were abuses nonetheless. In the $18^{\text {th }}$ and $19^{\text {th }}$ centuries in the United States, Americans could legally justify slavery by using the law and a need for social order as their justification, but that did not justify the morality of slavery. In a similar way, the phenomenon of the abuse of power, which has been present in all types of leadership and leadership systems, cannot be morally justified by somebody's ignorance or lack of understanding. Regardless of the current or previous interpretation, understanding, and justification of leadership the action of overstepping one's authority or of taking advantage of a position of power for personal gain has always been an abuse of power. While taking into account historical differences in the understanding of leadership, we considered biblical ideas on leadership as an ultimate determining measurement of a leader's behavior.

The issue of kingly power, as well as the discussions and measures of the 1901 and 1903 sessions of the GC, confirmed the existence of power abuses in church leadership in spite of the leaders' views on leadership. Thereby, the analysis of the abuses of power addressed those universal elements of power abuse proposed in the second chapter.

Christian servant leadership shares many elements with modern servant leadership perspectives, but it is unique in that it calls for double servanthood. It is 
Christocentric and mimetic. The ultimate leader is God. Thus, Christian leaders are the servants of the Lord and in service to all people. For them, greatness is not found in a position but in service. Leaders can have various types of power as long as their authority is submitted to God's authority.

While analyzing seven different types of power abuses this study concentrated on two leaders that often failed to be Christian servant leaders. Such abuses were, in their time, described as kingly power. There were many indicators that Kellogg and Daniells were autocratic leaders, in spite of their different ideology. Daniells experienced a common struggle in Christian leadership: an attempt to follow God's leadership and be the leader of people. Contrary to Kellogg's emphasis on practical Christianity, Daniells' first impulse was working for the salvation of others. He also attempted to surrender to God's leadership by emphasizing the importance of spirituality. ${ }^{137}$ While Kellogg did not deny the importance of spirituality and his institutions always had time for spiritual events, through the course of his life it seems that this aspect was secondary to his efforts to attend the physical health of people. Nonetheless, both of them overstepped their authority and forgot that they were in service to the Lord and were servants of the people. They were autocratic leaders, usually very strict with their subordinates, and surrounded by "yes people" because they could not accept censure or opposition. They were oversensitive to criticism, so everything had to be done their way. While they mistrusted subordinates they also created the idea that they were irreplaceable or at least stressed their significant importance to the church. Sometimes they were more concerned with

\footnotetext{
${ }^{137}$ John J. Robertson, A. G. Daniells: The Making of a General Conference President, 1901, 63-65.
} 
their own position or agenda than with serving others. In addition, they did not treat others as equals. Consequently, they fought to keep their positions.

They were supposed to cooperate with others for the advancement of God's work. Instead, Kellogg actively plotted against Daniells after their argument by influencing his colleagues and friends against him and using any possible method to remove him from leadership. ${ }^{138}$ Meanwhile, Daniells was trying to tame the Doctor and put him under the church's control.

Their example shows that when Christian leaders are not Christian servant leaders, they abuse their power. They misuse their authority, mistreat their subordinates or peers, and preserve their position of power rather than lead. Furthermore, they conduct themselves inappropriately, their corrupted character traits affect their leadership, they ignore Christian principles, and misplace their responsibility, authenticity and presence. Being a Christian servant leader means avoiding all those abuses. In the next chapter, after the summary of the analysis, some possible steps for the prevention of power abuses will be presented and suggested.

\footnotetext{
${ }^{138}$ Gilbert M. Valentine, The Prophet and the Presidents, 233.
} 


\section{CHAPTER 5}

\section{SUMMARY AND CONCLUSIONS}

In this final chapter some challenges facing Christian servant leaders will now be presented. Afterwards, the summary followed by a few final suggestions regarding leadership within the church will be offered to conclude the study.

\section{The Challenge of Being a Christian Servant Leader}

The ethical analysis in this study concentrated on only one aspect of leadershipthe misuse of power. Since the abuse of power is a deviation from true Christian leadership and morally inappropriate, the ethical analysis did not include typical moral dilemmas such as discerning between good and bad or right and wrong. Instead, the analysis in this study searched for the causes of the abuses of power. While it is not hard to achieve consensus in making a statement that abuses of power are immoral and that, especially among Christian leaders, such abuses need to be eradicated, detecting them and finding ways to achieve that goal (eliminating the abuses) could be challenging. Although many people have witnessed some form of abuse of power, such events are usually subtle, hard to prove, and often excused with positive outcomes. For effective leaders, power is a necessity, but controlling the corruptive nature of power while implementing the appropriate type and amount of power is imperative for Christian leadership. The careers of Daniells and Kellogg are examples of the complexity of relationships in leadership. Their leadership experience presents the effects of applying 
Machiavellian postulates in leadership practice and the challenges to the proper Christian use of power.

The challenge of Christian leadership is to empower both leaders and followers to achieve their goals but not abuse their power. There is a need of rising questions of inner motivation, the appropriate leadership methods, and the place of values such as honesty, transparency, and responsibility in leadership, which can be used to appropriately address challenges of Christian leadership. The main ethical question in spiritual leadership is: Is the leadership of our leaders morally justifiable?

Sometimes it is not easy to determine if leaders in the church abuse their power. For example, a leader may ask the members of his church to do certain "jobs" with or without him, promising them an amazing experience and God's blessings, but ultimately the leaders are paid from the very same offering that members gave to the church. In addition, the leader takes the credit for good achievements and blames his members for not doing enough in the case of failure. Ultimately, if the church is growing and the members are blessed with the experience of participation, can the leader be blamed for making them work to achieve a common goal? That is the reason why it is very hard to assess where the abuse of power starts. It is so easy to justify wrongdoing in the process when benefits accrue to all involved. The two leaders analyzed in this study $-\mathrm{J}$. H. Kellogg and A. G. Daniells - are good examples. While looking at their achievements, it is easy to overlook their misdeeds.

Nevertheless, ethical analysis requires honesty and this study is an attempt at addressing the important issue of power abuse. Christian leaders must not manipulate their followers. The same applied to Kellogg and Daniells. Of course, many of the issues 
discussed are not black and white; moral issues are very complex. It would be good that leaders never manipulate their followers. Nevertheless, many subordinates would not follow their leaders voluntarily if they would perceive their work as something benefit mostly their leaders. It is much easier to motivate followers who perceive that the benefits they receive from their work is greater than the struggle to achieve the given goals. Christian leaders have to persuade the members of the church to do tasks that are sometimes hard, dangerous, inconvenient or boring in order to achieve a specific goal. Sometimes it is easier to manipulate them than to be completely honest. Even Jesus' followers left him when He spoke to them honestly, the message and its requirements were too hard for them to accept. Consequently, it is often very hard to determine when a leader's requests are legitimate and when they are an abuse of power.

Nonetheless, spiritual leadership requires the highest standards. Christian leaders are supposed to have the wellbeing of their members first and foremost in their minds. Therefore, they should not manipulate them. In that regard, the two leaders analyzed in this study abused their power. How different was Jesus' leadership. He was ready to give and sacrifice, to love and forgive. Following his example, Christian servant leadership is ethically the most comprehensive (holistic) type of leadership. It includes the requirement that the leader should fulfill his obligation to do what is right regardless of the consequences (deontological), to have in mind the ultimate and highest goal for the individual and for the community (teleological), and to fulfill the previous two goals by upholding the highest standards and virtues of character (virtue ethics). Christian leaders determine what they are by what they do and what they do has to satisfy the principles of 
an ethical approach. No other type of leadership has requirements and standards set so high.

This study analyzed abuses of power as behavior or actions that violate principles and ethics of Christian servant leadership. While the Seventh-day Adventist Church attempted to deal with the abuses in its leadership with the change in organizational structure, no organizational structure can prevent all abuses of power. The pioneers were effective in creating an organization that, in theory, could minimize abuses of power. But the discrepancy between Christocentric theory and abusive practice proves that abuses of power depend on the personal conduct of the leader and how much his subordinates allow that leader to exercise such inordinate power. Because of human weaknesses and the corruptibility of power, it is easier to agree on a theoretical model than to put that model into practice. Maybe that is the reason that Jesus did not spend time creating a formal organization while he was on Earth.

While the motivations of others cannot be fully understood and/or judged, it seems that most spiritual leaders abuse their power because of their need to fulfill their responsibility. When they get in a position of power, they forget that their job is not to do God's job, but only to be his servants and to follow his instructions, bringing people to the real master. Ultimately, the personal decision of the leader to practice the principles of Christian servant leadership seems to be the most important element in avoiding abuses of power.

\section{Summary}

This dissertation does not emphasize any particular type of ethics (ethical system) intentionally. No ethical system is a perfect description of reality or completely correct. 
All systems are just human attempts to determine what is good and what is bad. And all of them are determined by the worldview and perception of the individual. Consequently, this study is affected by the Christian worldview and the values, goals, and virtues endorsed in this study are determined by Christian faith and derived from the biblical narrative. These goals are all centered in Christ, his salvific work, and his ultimate power.

Henlee H. Barnette stated, "It should be obvious that Christian ethics is both deontological and teleological in nature." Virtue ethics, in its ultimate goal of achieving the good through virtue, is teleological in nature; in its emphasis on the virtuous character rather than focusing on consequences it is deontological. Thus, according to this description, this study emphasized virtue ethics. That perception is evinced by the fact that the ideal of servant leadership was found in Christian virtues. In addition, the abuse of power was understood as an act of misconduct or as a vice performed as the result of ignorance of Christian values.

Nevertheless, deontology and teleology are present in the proposed model of Christian servant leadership and in the analysis of power abuses as well. While Christian leaders uphold principles (deontological), they also look for good outcomes (utilitarian), and they are doing it by endorsing and practicing Christian values (virtue ethics) as the means of doing good and achieving the ultimate goal, namely an eternal future with God in God in His kingdom. This ethical framework was the basis for this study.

This study consists of five chapters. In the introductory chapter the main points of the study were presented. The second chapter presented a theoretical framework for an 1961), 5 .

${ }^{1}$ Henlee H. Barnette, Introducing Christian Ethics (Nashville, TN: Broadman Press, 
ethical analysis of the abuses of power in Christian leadership. The framework included and proposed the ideal model of Christian leadership. Each part of the framework has its counterpart in seven particular types of abuses of power, which were noted in the proposed pattern for analysis at the end of the chapter. All of the seven types of abuses are in opposition to the proposed Christian servant leadership model, which presents a Christian leader as the servant of God and the people.

The third chapter presented the historical and ecclesiological background of the "kingly power" controversy in the Seventh-day Adventist Church. In the fourth chapter that controversy was used for the ethical analysis of abuses of power by the two most prominent figures, J. H. Kellogg and A. G. Daniells. Furthermore, reasons for the abuse of power were indicated and possible measures to minimize its occurrence were suggested. In addition, abuses of power were categorized as follows: abuses related to misuse of authority, to mistreatment of subordinates, to preservation of power, to misconduct of a leader, to corrupted character traits, to ignoring Christian principles, and to misplaced responsibility, authenticity and presence.

In the section on Abuses related to misuse of authority, the study concentrated on the examples of both leaders, Kellogg and Daniells, who overstepped their authority. Both leaders exhibited an autocratic style of leadership and refused to exercise their power within the limits of their mandate. Kellogg's mandate was to lead the church's health institution and to advance the mission of the church. Instead, he took over the institution and behaved like the owner of the institution, a position he ultimately achieved by becoming the largest stockholder. He fought hard to eliminate any potential or existing competition or opposition. He undermined the power and authority of subordinates while 
emphasizing his own achievements and those of his institutions. One of his most common excuses for his autocratic behavior was that there was no one else to do the job.

Daniells employed a similar argument to excuse his behavior. In addition, his autocratic leadership style was supported by his strong convictions. When he felt that he was right, he would impose his convictions on others with great force and determination. He also removed all those who stood in his way. As a "chain-of-command" person, sometimes ruling over brethren, Daniells overstepped his authority. Like Kellogg, whenever he ruled, Daniells rejected the leadership style of Jesus, who proposed love over fear, humility over greatness, and equality - the priesthood of all believers - over rulership.

In their positions both leaders very successfully used political maneuvering to achieve their goals and keep their positions of power. However, Daniells further abused his power by confusing and equating principles with policies and by giving moral significance to all his decisions.

This section suggested that abuses of power are often the result of taking extreme positions and being inflexible. In addition, the following points were also suggested. First, Christian leaders must follow the leadership of Christ and not become selfsufficient. Ultimately, a leader must be aware of who is the real leader. Next, a leader must be transparent to minimize the possibility of political maneuvering and remember that it is not his/her responsibility to change or control people and institutions. Furthermore, leaders need to implement the theology of the priesthood of all believers to prevent abuses of power. Finally, their mandates have to be limited and well defined. 
In the section on Abuses related to mistreatment of subordinates it was noted that such abuses are the consequence and result of the misuse of authority. Christian leaders are defined by two principles: they are to submit to God and they are to serve the people. Thereby, they should treat their subordinates appropriately and they should accept the headship of Christ.

Daniells' natural determination was negatively reflected in his tendency to rule over his colleagues. He expected obedience from his subordinates and he was harsh to those who did not comply or obey. As a result, he mistreated his subordinates. Kellogg's mistreatment of his subordinates was even more obvious. He insisted that he was always right, he deliberately undercut and ignored committees, he treated his potential competition badly, and he never shared his responsibilities. He never trusted others, so his subordinates were left with only two options: to follow him or to leave. He also provided substandard service for his employees to save money. While he expected others to follow the church's proposed health principles strictly, he did not hold himself to the same standard, except for strict vegetarianism.

In this section the analysis of abuses of power suggested that abuses related to mistreatment of subordinates have their roots in a wrong concept of the nature of Christian leadership and its mandate, as well as the wish to be in control and a feeling of superiority. Prevention of such abuses can include increasing awareness of the main principles of Christian leadership, which are the equality of all believers, the responsibility of all believers to serve the needs of the church and other humans, and the potential danger of the urge to control and rule. Subordinates and leaders are supposed to act as checks and balances for each other. 
The section on Abuses related to preservation of power analyzed the corrupted quality of power that is based on the desire of the person to maintain his or her position of power, with all its potential benefits. Unique to Christian leadership is the dichotomy of being in power while submitting that power to God and in service to others. Regardless of the reasons for the preservation of power, whether personal insecurity, pride, or the prevailing opinion and feeling that being in power means to be successful, such behavior is in opposition to Christ's example of humility and service.

Kellogg tried to sustain his power by refusing to allow anyone to outshine him. In addition, he refused to share his responsibilities. If necessary, he would plot against his competition and try to manipulate the situation by playing power games or criticizing the person who threatened his position. He presented himself as an irreplaceable asset to the church and asserted that the success of his institution depended on him. His true loyalty was to the institution and his position in the institution. According to some, he treated his enemies better than his friends, and he did not easily admit his mistakes. He attacked and intimidated the competition because he was worried about keeping and maintaining his position of power.

While Daniells' methods of self-preservation were more subtle, he vigorously tried to preserve his power. He used his employer - employee relationship with his subordinates to keep his power. On many occasions he used his strict adherence to the rules and policies as a method to help him preserve his power. He was accused by his friends and his adversaries of using kingly power. To preserve that power, he used political methods, always finding good and/or pious reasons to justify his actions. 
There were occasions when he presented an incomplete picture of events to show God's approval of the actions of church administration. He was able to keep his position as president of the GC for twenty-one years. When he was replaced there was controversy in the midst of his desperate attempt to maintain his position. In his defense, he used spiritual arguments that evinced God's guidance in his actions. He never claimed prophetic authority, but his claims almost implied as much. However, when his arguments proved insufficient he would use the words of the church's prophet to support his policies and his position.

Daniells understood the importance of image for the preservation of power. When he would put another person's ideas in practice, he would claim credit for himself. That was usually a very effective method of sustaining his power. Furthermore, Daniells used his conflict with Kellogg as another method to preserve his power. Kellogg also used this method for the same purpose.

The section on abuses related to preservation of power described how both leaders used power tactics that resulted from selfish motives. Such tactics should always be clearly declared as anti-Christian. Christian leaders should place their service to God and people before their personal interests. To prevent such abuses leaders must be reminded that they are not irreplaceable, that their mandate is temporary, and that they have to follow Jesus' example. While some practical solutions for the problem would include limiting a leader's time in office, mandating changes or rotations in the leadership position, clearly defining the boundaries and limits of a particular position, and educating leaders regarding the extent and limitations of their position, such measures need to be 
implemented carefully. However, there is no policy that is as effective as a leader's personal decision to reject the corruptibility of power.

The section on Abuses related to the misconduct of a leader discussed two major ethical systems, deontology and utilitarianism. In utilitarianism, the action is morally justified if it serves the purpose of bringing to fruition a good final outcome. Deontology considers conduct morally appropriate if it upholds moral principles regardless of the consequences. While no one completely adheres to one particular system, it is easy to see that the leadership of Kellogg mostly fits the utilitarian approach and the leadership of Daniells mostly fits the deontological approach. When a leader attempts to achieve a good ultimate goal through bad methods (utilitarianism) and when a leader applies principles and norms arbitrarily and carelessly without considering how they would affect others (deontology), this leads to abuse power.

Daniells' application of principles lacked compassion and exhibited narrowmindedness. He tried to persuade others to follow and comply with his own convictions. He was inflexible in his application of policy and he was unwilling to change his opinion. His conduct became abusive when he lacked the ability to create a balance between upholding principles and applying them in a practical manner. While upholding principles, especially in somebody's own life, is desirable, imposing those principles and attempting to control others is an abuse of power. In so doing one assumes the role of God, who is the one who has the right to enforce principles. However, he instead gives humans free will and the right to choose.

The conduct of both leaders included abuses of power. However, Kellogg was more concerned with the final outcome than the method used in the process. He was 
controlling and autocratic to make the world a better and healthier place. He was judgmental toward those who were less educated and toward those who did not practice the health principles promoted by the church. He attacked and removed his opposition, he also acted defensively, and he was always ready to manipulate situations to achieve his good goals. His abuses and manipulations were the result of his assumption that the goal justifies the means.

From the two leaders it can be learned that extreme strictness and a pragmatic focus on a noble goal that uses morally corrupt methods are both equally detrimental to Christian leadership. A desirable form of leadership would include an appropriate balance between pursuing a good ultimate goal and upholding the highest moral principles. The practical methods of achieving that goal should include: sharing responsibility, empowering the whole body of the church, and making decisions through committees to shift power from the hands of the individual to the whole church.

The section on Abuses related to corrupted character traits emphasizes the importance of a leader's character in Christian leadership. As imitators of Christ Christian leaders are supposed to nurture moral virtue in their life and lead by example. Corrupted character qualities lead to abuse of power.

Unfortunately, the weaknesses of Kellogg and Daniells led to abuses of power. Additionally, some morally neutral qualities also led to abuses of power. Daniells was sometimes so stubborn that he used unnecessary force to achieve a goal and he sometimes refused to give up when it was necessary. He also overworked himself, which caused depression and negatively affected his leadership. He was also domineering, selfconfident, and arrogant. The result of such behavior was the feeling of irreplaceability. 
Consequently, he began to place himself in the position of God, which prevented him from using the gifts of others.

Kellogg is a good example of how great qualities and virtues can be misused. He was very capable of influencing others, but he, unfortunately, used that talent to control them and to fulfill his own agenda. While his motivation was a strong force in his life, his pride, drive to preserve himself and his successes, and his strong desire for recognition were vices that led to many cases of abuse of power. In the end, his strong will failed to overcome his vices, and that negatively affected his leadership.

This section suggested that the first step in dealing with abuses related to corrupted character traits is awareness of one's personal weakness and vices. It is important that peers, coworkers, and subordinates serve as checks and balances in case a leader ignores his/her personal frailties. Essentially, the purpose of the election process is to elect a leader that has the least amount of vices, since no one is perfect. Subordinates and the electorate have the responsibility to act as checks and balances because a leader's vices may prevent them from leaving their leadership position; also they may even sometimes replace them. However, controlling and overcoming such a leader is usually impossible without God's intervention.

The section on Abuses related to ignoring Christian principles suggested that Christian leaders have to follow "true north" principles by following the teachings of the Bible and the example of Jesus. Ignoring those principles leads to double standards and abuses of power. Kellogg's double standards were visible in that he cared for the less fortunate while exploiting his workers. This was also displayed in his strictness in 
requiring pastors to practice all elements of the health reform ${ }^{2}$ while excusing himself from the similar obligation. ${ }^{3}$ In addition, Kellogg followed a double standard by his official endorsement of the Church and its teachings publicly, yet denying them in his practice and beliefs.

Daniells professed agreement with church teaching, but he did not completely practice the health message of the church. While he officially worked toward reconciliation with Kellogg, he abused his subordinates who did not side with him in the conflict with Kellogg. This discrepancy between belief and practice was another example of Daniells' abuse of power.

This section pointed out that ignoring principles and preaching but not practicing them jeopardizes a leader's authority and leads to abuse of power. To prevent these abuses leaders need to have clear principles and they have to practice them. Not practicing the principles of Christianity disqualifies Christian leaders for leadership. Leaders need to be people of principle. Said Ellen White, "The greatest want of the world is the want of men - men who will not be bought or sold, men who in their inmost souls are true and honest, men who do not fear to call sin by its right name, men whose conscience is as true to duty as the needle to the pole, men who will stand for the right though the heavens fall."4

The analysis of Abuses related to misplaced responsibility, authenticity, and presence pointed out the necessity of applying all three components of ethical leadership

${ }^{2} \mathrm{He}$ had continuously reproving them for not being vegetarian.

${ }^{3} \mathrm{He}$ stated that he did not have time to practice some elements of the health reform such as appropriate balance of work and sleep.

${ }^{4}$ Ellen G. White, Education (Nampa, ID: Pacific Press, 2002), 57. 
in Christian leadership. In spite of the importance of all three, the emphasis of this study is on responsibility. The reason is simple. Wrongly understood responsibility is a very common source of power abuse in Christian leadership.

Kellogg's use and misuse of power is a good example of how all elements of ethical leadership have both their strengths and weaknesses. For example, Kellogg sometimes used his presence for the benefit of the church and sometimes for his private agenda. Christian leadership is supposed to reflect the positive side of the elements of ethical leadership. Fulfilling one's responsibility is a necessary element for good leadership, but when leaders start to feel responsible for things that are not their responsibility, they will soon abuse their power.

For his part, Daniells believed his responsibility was to make sure everybody worked efficiently and responsibly. He also felt that his responsibility was to protect the church and the church's prophet. That led him to a wrong understanding of his mandate and a wrong method to fulfill that mandate. His attempt to rule over the church was related to his misconception of his responsibilities.

In order to avoid such abuses, leaders must practice all principles of ethical leadership. The responsibilities of leaders have to be understood correctly. While some spiritual leaders, on rare occasions, have the prophetic responsibility of giving a direct message from God and of upholding his authority, most spiritual leaders only hold leadership responsibilities. They are to be servants of the Lord and in service to the people. And, they need to understand that their responsibility is not to take God's place in solving people's or institutional problems but to fulfill their duty and create an 
atmosphere in which God will work. Sharing responsibility and credit for achievements with others is one simple method to prevent such abuses.

All these discussed abuses of power have one thing in common. They point to a failure to follow the principles of Christian servant leadership. Ideally, Christian leaders are servants of the Lord and in service to people. The most important question is not what their leadership style is or which leadership method they use. The most important question is if they have submitted their power to God's authority and treated their brethren properly. The list of potential abuses can be very extensive. This study can serve as an introduction to further study of those abuses and of possible steps to avoid these abuses. Putting all power in the hands of any human will lead to an abuse of power. In a similar way, expecting one study to propose all solutions for such a complex problem such as the abuse of power is also problematic. Therefore, the steps suggested in this study are a simple attempt to propose some potential solutions, with the goal of starting a constructive discussion on practical steps to prevent power abuse. Ultimately, the expectation is that "a multitude of counselors" will bring more and better ideas to improve Christian leadership.

\section{Some Final Suggestions}

This study dealt with the important issue of abuses of power, analyzing a case from the past. However, there is a striking similarity between contemporary issues and the case study presented. Just as the Seventh-day Adventist Church was facing conflict between the medical and ministerial branches of the church at the beginning of the twentieth-century, the church today is facing conflict between conservative and liberal (progressive) groups within the church. Unfortunately, the respective groups tend to 
present any issue as salvific in nature and fundamental to the beliefs of the church. Thus, they have become embroiled in an interminable struggle over leadership and morality.

That conflict also includes a struggle between two ways of thinking about church organization that also has ethical connotations: one that emphasizes unity in mission and another that emphasizes the principles of the headship of Christ, the priesthood of all believers, and salvation by faith. While both views have biblical support and practical value, they need to be implemented together in an appropriate leadership structure. The outcome of the struggle will affect how the church will address several important issues such as gender equality, the difference between "laity" and pastors or pastor vs. priest, the question of the biblical basis for our actions, and the authority of the church. It seems that in 1903 the church erred by rejecting the minority report. If we repeat that mistake, the church may err in the same manner today.

While this study does not deal with contemporary issues directly, the church of today can learn from the past. The following suggestions cannot give a final solution to all the questions, but they are based on lessons learned from the past and can be used as a starting point toward finding the solutions for current issues.

Spiritual leaders are supposed to be servants of God, his people, and humanity. While their position includes honor, rights, and responsibilities, leaders always need to be reminded of the limitations of their responsibility and their spiritual mandate. The longer they are in a leadership position, the easier it is for them to forget that they are not rulers but servants.

Some leaders, in their search for order in the church, also believe that they are the protectors of the church. While leaders bear the responsibility for the institution they 
lead, wrong understanding of that responsibility might lead to the same mistake Daniells and Kellogg made by equating principles with policies and procedures. Nevertheless, principles, policies, and procedures must not be confused. While principles are the universal and unchangeable ideals to which our moral compass has to turn and the basis for our decisions, policies and procedures are the application of those principles limited by time, culture, and contemporary conditions. If time or conditions change then policies and procedures could be and sometimes must be changed. Insisting that policies and procedures are immutable like principles leads to an abuse of power.

Many problems and abuses are the results of partial solutions and extreme positions. If we would learn from the church's past mistakes, we might not simply accept a partial solution. Maybe the church would not have lost some prominent leaders of the first and second generation of Adventists leaders if it would have included the minority report of the $1903 \mathrm{GC}$ session in their decisions. They included the ideas from the report, at least in theory, later anyway. Inclusiveness and tolerance might be more important for unity than consensus in doctrinal questions. All too often doctrinal fights in the church had a political impetus instead of a spiritual one. That was a probable reason for the pioneers' rejection of creeds, or for E. G. White's silence during many doctrinal debates.

The education of leaders and their subordinates needs to be improved. It seems that too often it is assumed that elected leaders and their electorate know what their job and responsibilities are. Unfortunately, the lack of that type of knowledge is one of the reasons for abuses of power and the discrepancy between theory and practice. The checks and balances cannot be established without knowing what our duty is in the first place. How many current members of the church really understand that a local church and a 
conference of churches are supposed to be checks and balances for each other, that the role of the conference is to distribute resources better between local churches, that the conference is not the ruler over the churches, and that the local church has the right to be informed about the activities of the conference and to question the conference in the case of wrongdoing?

While the current church organization has an efficient structure in theory, in practice there is need for some adjustments. For example, GC sessions, which include a huge electoral body, increases the potential for some power abuses. Specifically, when the global church gets together for a GC session to make administrative decisions, the body of more than 2,500 delegates is too big to allow each delegate to have a voice. Such a big electoral body gives too much power in the hands of the administration in charge of managing the session caused by a lack of time or the impracticality of some motions or procedures.

Necessary adjustments might include measures to help the church better reflect certain proclaimed beliefs such as the headship of Christ, the priesthood of all believers, the church as the body of Christ, salvation by faith, and spiritual gifts in addition to the already implemented idea of unity for mission. Furthermore, the church might need to address some current post-pioneers' practices such as instead of having the pastors take care of the local church in a quasi-priest position, let the local elders and deacons maintain the edifice, which was the model in early Christianity. The church also needs to address the issue of the current understanding of ordination, which puts a pastor at a higher-ranking position than any other church member, making him a de facto priest among the laity. 
While there are pragmatic reasons to maintain a system that sustains an organization of paid pastors, it is important to raise awareness of the problems such system introduces and to search for solutions to them. This type of organization introduces a business model into the church - an employer-employee relationship. It also opens the door for potential conflicts of interest - being paid for spiritual service and fulfilling the responsibility of all Jesus' followers. Thus we need to raise some questions: Do ministers/leaders do what is right, being authentic, and serve the Lord? Or do they work simply to keep their job and to maintain a source of income for them and their family? Do leaders maintain their integrity in service to the Lord and God's church or do they work for personal and/or selfish interests? Do leaders use the pressure of the employer-employee relationship to push their agenda? While there are no easy or simple answers to those questions, the search for solutions starts by asking those questions.

In the church, which is a spiritual entity, there is no human boss, members are equal, and rulership is simply wrong. It is important to understand that the leaders of the church, regardless of their title - pastor, elder, president, secretary, or treasurer - are neither bosses nor rulers. Consequently, all power in the church must be dispersed and shared within the church body. Power is essential to achieving genuine and positive change. In addition, organization is also necessary for constructive change, as well as functional hierarchy. Every organization needs structure and therefore some functional hierarchy. At the same time, a hierarchy in the form of a pyramid (with power going from top to bottom) must be rejected based on the facts that the only kingly power in the church belongs to God and that the church has been organized on the principle of the equality of all believers (the priesthood of all believers). This study confirms once again 
that concentrating too much power in any human individual is very dangerous.

Unfortunately, as the result of many influences, misconceptions of spiritual leadership, and the weaknesses of human nature a complex balance between functional hierarchy (with appropriate application of power and influence) and the equality of all believers is rarely reached. However, the church needs to strive continuously for the right balance between functional hierarchy (respect for and compliance with legitimate authority) and the equality of all members ("all brethren") rather than avoiding the problem.

It is crucial to the prevention of the misuse of power that, while in positions of responsibility, leaders submit their authority to the authority of the bodies they chair. Those bodies have the responsibility of keeping their chairs or leaders accountable. While the first responsibility of all Christian servant leaders is to follow God's leadership, it is the responsibility of all members of the body to resist possible abuses of leadership. It is usually hard for any leader in a position of power to notice his or her weaknesses. The role of their colleagues and those who are led by their authority is to support them, work with them, and help them not to use their power irresponsibly. While this is not an easy task to do, based on the correct understanding of the priesthood of all believers, the subordinates and coworkers are supposed to act as checks and balances for their leaders. As W. C. White said, all leaders, including the president of the GC, are supposed to do as their boards or their brothers and sisters advise them. They are servants of the Lord and his church. ${ }^{5}$

\footnotetext{
5"The General Conference Bulletin: Thirty-Fifth Session," The General Conference of Seventh-day Adventist Church, April 10, 1903, 158.
} 
This type of study is new within the Adventist Church; therefore, this study is only an introduction to the topic. The purpose of the study is to raise awareness of the issue within the Church. Nevertheless, the abuses described in the study are not unique to the Seventh-day Adventist Church. The abuse of power is a universal problem that affects spiritual leadership. The future of any church, as well as the effectiveness of its leaders, will be affected by how well spiritual leaders avoid the traps of power abuse.

This case study of historical events and people discussed the principles related to the moral dilemmas of present-day leadership and sought to offer solutions to avoid corruption. Seven reasons for the existence of power abuses were suggested, but further studies might suggest additional causes. A correct understanding of the reasons and causes of power abuse is an essential step towards prevention. Additionally, such studies need to address the following questions: Why does power have such an appeal? How can churches implement effective checks and balances of leadership? How can a church improve its organizational structure to increase its effectiveness and minimize the occurrence of power abuse? 


\section{BIBLIOGRAPHY}

Adair, John E. The Leadership of Jesus and Its Legacy Today. Cleveland, OH: Pilgrim Press, 2002.

Anderson, Joe. "The Writings of Robert K. Greenleaf: An Interpretive Analysis and the Future of Servant Leadership." Servant Leadership Research Roundtable, May 2008 .

Aristotle. Nicomachean Ethics. Edited and translated by Roger Crisp. New York: Cambridge University Press, 2000.

Baker, Alonzo L. "My Years with John Harvey Kellogg." Spectrum Autumn 1972 (1972): 40-45.

Bassett, John Spencer. A Short History of the United States, 1492-1920. New York: The Macmillan Company, 1925.

Basso, Hamilton. "Theodore Roosevelt: The American Progressive." In Theodore Roosevelt: A Profile, edited by Morton Keller. New York: Hill and Wang, 1967.

Baumgartner, Erich W. "Church Growth and Church Structure: 1901 Reorganization in the Light of the Expanding Missionary Enterprise of the SDA Church." Term Paper, Andrews University, 1987.

Beach, Waldo and H. Richard Neibuhr. Christian Ethics: Sources of the Living Tradition. New York: The Ronald Press Company, 1973.

Beasley-Murray, Paul. Power for God's Sake: Power and Abuse in the Local Church. Carlisle, PA: Paternoster, 1998.

Bekker, Corne J. "Towards a Theoretical Model of Christian Leadership." Journal of Biblical Perspectives in Leadership 2, no. 2 (Summer 2009): 142-152.

Bennis, W. "Become a Tomorrow Leader." In Focus on Leadership Servant-Leadership for the Twenty-First Century, edited by Larry C. Spears and Michele Lawrence, xiv, 396. New York: J. Wiley \& Sons, 2002.

Bibleworks 9 Software for Biblical Exegesis \& Research. Norfolk, VA: Bibleworks, 2011. 
Blanchard, K. and P. Hodges. The Servant Leader: Transforming Your Hearts, Heads, Hands, and Habits. Nashville, TN: Thomas Nelson, 2003.

Boyd, Gregory A. God at War: The Bible \& Spiritual Conflict. Downers Grove, IL: InterVarsity Press, 1997.

Brueggemann, Walter. Theology of the Old Testament: Testimony, Dispute, Advocacy. Minneapolis, MN: Fortress Press, 1997.

Bruinsma, Reinder. The Body of Christ: A Biblical Understanding of the Church. Hagerstown, MD: Review and Herald 2009.

Brunt, John and Gerald Winslow. "The Bible's Role in Christian Ethics." Andrews University Seminary Studies Vol. 20, no. 1 (Spring 1982): 3-21.

Burton, David H. The Learned Presidency: Theodore Roosevelt, William Howard Taft, Woodrow Wilson. Rutherford: Fairleigh Dickinson University Press, 1988.

Burton, Kevin M. "Centralized for Protection: George I. Butler and His Philosophy of One-Person Leadership." MA Thesis, Andrews University, 2015. Accessed on February 25, 2016.

http://www.academia.edu/19481029/Centralized_for_Protection_George_I._Butle r_and_His_Philosophy_of_One-Person_Leadership.

Calvin, John. Institutes of the Christian Religion: 1541 French Edition. Translated by Elsie Anne McKee. Grand Rapids, MI: William B. Eerdmans Publishing Company, 2009.

Campolo, Anthony Jr. The Power Delusion. Wheaton, IL: Victor Books, 1983.

Clarke, Arden W. "And the People Said, 'We Will Serve the Lord"': An Analysis of Church Government. Brushton, NY: TEACH Services, 2001.

Covey, Stephen R. Principle-Centered Leadership. 1st ed. New York: Simon \& Schuster, 1992.

Cox, Harvey G. "Power." In A New Dictionary of Christian Ethics, edited by James F. Childress; John Macquarrie, 486. London: SCM Press Ltd, 1990.

Crouch, Andy. Playing God: Redeeming the Gift of Power. Downers Grove, IL: IVP Books, 2013.

De Pree, Max. Leading Without Power: Finding Hope in Serving Community. Holland, MI: Shepherd Foundation, 1997.

Dederen, Raoul. "The Church." In Handbook of Seventh-day Adventist Theology, edited by Raoul Dederen, Commentary Reference Series, vol. 12,, 538-581. Hagerstown, MD: Review and Herald, 2000. 
Dittes, Albert. Three Adventist Titans: The Significance of Heeding or Rejecting the Counsel of Ellen White. Ringgold, GA: Teach Services, 2013.

Durant, Will. The Story of Philosophy: The Lives and Opinions of the Greater Philosophers of the Western World. 2d ed. New York: Simon and Schuster, 1961.

Dybdahl, Jon. Hosea-Micah: A Call to Radical Reform. The Abundant Life Bible Amplifier. Edited by George R. Knight and B. Russell Holt. Boise, ID: Pacific Press 1996.

Enroth, Ronald M. Churches That Abuse. Grand Rapids, MI: Zondervan Publishing House, 1992.

Everist, Norma C. and Craig L. Nessan. Transforming Leadership: New Vision for a Church in Mission. Minneapolis: Fortress Press, 2008.

Foerster, W. "exousia [power to act, authority]." In Theological Dictionary of the New Testament, edited by Gerhard Kittel, Gerhard Friedrich, and Geoffrey William Bromiley, xxxvi, 1356. Grand Rapids, MI: W.B. Eerdmans, 1985.

Forbes, Cheryl. The Religion of Power. Grand Rapids, MI: Zondervan Publishing House, 1983.

Foster, Richard J. Money, Sex \& Power: The Challenge of the Disciplined Life. San Francisco, CA: Harper \& Row, 1985.

Foucault, Michel. Discipline and Punish: The Birth of Prison. Translated by Alan Sheridan. New York: Vintage Books, 1979.

Foucault, Michel. The History of Sexuality. Translated by Robert Hurley. New York: Pantheon Books, 1978.

Foucault, Michel and Colin Gordon. Power/Knowledge: Selected Interviews and Other Writings, 1972-1977. 1st American ed. New York: Pantheon Books, 1980.

French, John R. P., Jr. and Bertram Raven. "The Bases of Social Power." In Studies in Social Power, edited by Dorwin Cartwright, ix, 225. Ann Arbor, MI: Research Center for Group Dynamics Institute for Social Research University of Michigan, 1959.

Gaventa, Jonathan. "Power after Lukes: An Overview of Theories of Power Since Lukes and Their Application to Development." (2003). Accessed October 7, 2015. www.powercube.net/wp-content/uploads/2009/11/power_after_lukes.pdf.

General Conference of Seventh-day Adventist. Seventh-day Adventist Church Manual. Silver Springs, MD: General Conference of the Seventh-day Adventist Church, 2003. 
General Conference of Seventh-day Adventists, Ministerial Association. Seventh-day Adventists Believe... A Biblical Expositions of 27 Fundamental Doctrines. Silver Springs, MD: Ministerial Association, General Conference of Seventh-day Adventists, 1988.

General Conference of Seventh-day Adventists, Ministerial Association. Seventh-day Adventists Believe... A Biblical Exposition of Fundamental Doctrines. Silver Spring, MD: Ministerial Association, General Conference of Seventh-day Adventists, 2005.

"General Conference Proceedings." The General Conference Bulletin, Thirty-fifth Session, April 6, 1903.

"General Conference Proceedings." The General Conference Bulletin, Thirty-fifth Session, April 7, 1903.

Gini, Al. My Job, My Self: Work and the Creation of the Modern Individual. New York: Routledge, 2000.

Gould, Lewis L. The Presidency of Theodore Roosevelt. Lawrence, KS: University Press of Kansas, 1991.

Graubard, Stephen. Command of Office: How War, Secrecy, and Deception Transformed the Presidency from Theodore Roosevelt to George W. Bush. New York: Basic Books, 2004.

Greene, Robert and Joost Elffers. The 48 Laws of Power. New York: Viking Adult, 1998.

Greenleaf, Robert K. Servant Leadership: A Journey Into the Nature of Legitimate Power and Greatness. New York: Paulist Press, 1991.

Greenleaf, Robert K. The Servant-Leader Within: A Transformative Path. Edited by Hamilton Beazley, Julie Beggs, and Larry C. Spears. New York: Paulist Press, 2003.

Gregory, Joel C. Too Great a Temptation: The Seductive Power of America's Super Church. Fort Worth, TX: Summit Group, 1994.

Grenz, Stanley J. The Moral Quest: Foundations of Christian Ethics. Downers Grove, IL: InterVarsity Press, 1997.

Grundmann, W. "dynamis [ability, power]." In Theological Dictionary of the New Testament, edited by Gerhard Kittel, Gerhard Friedrich, and Geoffrey William Bromiley, xxxvi, 1356. Grand Rapids, MI: W.B. Eerdmans, 1985.

Gula, Richard M. Ethics in Pastoral Ministry. New York: Paulist Press, 1996. 
Gustafson, J. M., E. L. Long Jr., and H. R. Niebuhr. "Christian Ethics." In The Westminster Dictionary of Christian Ethics, edited by James F. Childress and John Macquarrie. Philadelphia: The Westminster Press, 1986.

Hardy, Andrew, Richard Whitehouse, and Dan Yarnell. Power and the Powers: The Use and Abuse of Power in its Missional Context. Eugene, OR: Cascade Books, 2015.

Hayward, Clarissa Rile. "On Power and Responsibility." Political Studies Review 4 (2006): 156-163.

Hellerman, Joseph H. Embracing Shared Ministry: Power and Status in the Early Church and Why It Matters Today. Grand Rapids, MI: Kregel Academic, 2013.

Hu, J. and R.C. Linden. "Antecedents of Team Potency and Team Effectiveness: An Examination of Goal and Process Clarity and Servant Leadership." Journal of Applied Psychology 96, no. 4 (2011): 851-862.

Hyde, J. K. Concepts of Power in Kierkegaard and Nietzsche. Farnham, England: Ashgate, 2010.

Johnson, David and Jeffrey VanVonderen. The Subtle Power of Spiritual Abuse. Minneapolis, MN: Bethany House Publishers, 1991.

Jones, A. T. Church Organization. Words of Truth. Battle Creek, MI: Review and Herald, 1901.

Jones, Alonzo T. "Evening Sermon." The General Conference Bulletin, Thirty-fourth Session, April 4, 1901.

Jones, Alonzo T. "Saving Health." The Review and Herald vol. 75, no. 47 (November 22, 1898).

Jones, Alonzo T. An Appeal for Evangelical Christianity. Battle Creek, MI: 1909. http://www.adventpioneerbooks.com/Text/pioneer/ATJONES/AEC.pdf.

Jorgensen, Gilbert. "An Investigation of the Administrative Reorganization of the General Conference of Seventh-day Adventists as Planned and Carried Out In the General Conferences of 1901 and 1903." MA Seventh-day Adventist Theological Seminary, Washington D.C., 1949.

Kaiser, Denis. "Setting Apart for the Ministry: Theory and Practice in Seventh-day Adventism (1850-1920)." Andrews University Seminary Studies Vol. 51, no. 2 (2013): 177-218. http://digitalcommons.andrews.edu/auss/vol51/iss2/2.

Kant, Immanuel. Groundwork for the Metaphysics of Morals. Edited by Allen W. Wood Rethinking the Western Tradition. New Haven: Yale University Press, 2002. http://ezproxy.cc.andrews.edu/login?URL=http://site.ebrary.com/lib/andrews/Doc ?id=10170770. 
Keller, Catherine. "Power Lines." In Power, Powerlessness, and the Divine: New Inquiries in Bible and Theology, edited by Cynthia L. Rigby, xvii, 305. Atlanta, GA: Scholars Press, 1997.

Kellogg, John H. "Rise and Development of the Sanitarium Work." The Gospel of Health vol. 2, no. 8 (August 1898): 145-151.

Kellogg, John H. "Serious Thoughts for Serious People." The Review and Herald vol. 63, no. 1 (January 5, 1886).

Kellogg, John H. "True Education." Good Health, January, 1889.

Kent, Keri W. Deeper Into the Word: Old Testament: Reflections on 100 Words from the Old Testament. Kindle ed.: Baker Book Group, 2011. Accessed January 6,2013.

Kierkegaard, Søren. The Moment and Late Writings. Edited and translated by Howard V. Hong and Edna H. Hong. Princeton, NJ: Princeton University Press, 1998.

Knight, George. Organizing to Beat the Devil: The Development of Adventist Church Structure. Hagerstown, MD: Review and Herald Pub. Association, 2001.

Knight, George R. A. T. Jones: Point Man on Adventism's Charismatic Frontier. Hagerstown, MD: Review and Herald Publishing Association, 2011.

Knight, George R. From 1888 to Apostasy: The Case of A.T. Jones Washington, DC: Review and Herald Pub. Association, 1987.

Knight, George R. If I Were the Devil: Seeing Through the Enemy's Smokescreen: Contemporary Challenges Facing Adventism. Hagerstown, MD: Review and Herald Pub., 2007.

Knott, Bill. "The Nearly Adventist President." Adventist ReviewJanuary 26, 2006.

Lebacqz, Karen. Professional Ethics: Power and Paradox. Nashville, TN: Abingdon Press, 1985.

Leuchtenburg, William E. . The American President: From Teddy Roosevelt to Bill Clinton. Oxford University Press, 2015.

Long, D. S. Christian Ethics: A Very Short Introduction. New York: Oxford University Press, 2010.

Loughborough, J. N. The Church: Its Organization, Order and Discipline. Washington DC: Review and Herald, 1907.

Lukes, Steven. Power: A Radical View. 2nd ed. New York: Palgrave-Macmillan, 2005.

Machiavelli, Niccolò. The Prince. Translated by Harvey C. Mansfield, Jr. Chicago: University of Chicago Press, 1985. 
Machiavelli, Niccolo. The Prince and Other Writings. Translated by Luigi Ricci and J. Scott Berley. Digireads.com Publishing, 2012.

Machiavelli, Niccolo. The Prince and Other Writings [with Biographical Introduction] Kindle ed. Translated by Luigi Ricci. Lawrence, KS: Neeland Media LLC, 2012.

MacIntyre, Alasdair C. After Virtue: A Study in Moral Theory. 3rd ed. South Bend, IN: University of Notre Dame Press, 2007.

Magan, Percy T. "John Harvey Kellogg, Apostle of Health." Health, July, 1942.

Marias, Julian. History of Philosophy. New York: Dover Publications Inc., 1967.

Maritain, Jacques. Man and the State. Chicago: University of Chicago Press, 1962.

Maxwell, John C. The 21 Irrefutable Laws of Leadership. Nashville, TN: Thomas Nelson, 1998.

McArthur, Benjamin. "A. G. Daniells and Lessons of Leadership." Adventist Today, Spring 2015, 2015.

McArthur, Benjamin. A.G. Daniells: Shaper of Twentieth-Century Adventism. Nampa, ID: Pacific Press, 2015.

McGrath, Alister E. "A Better Way: The Priesthood of All Believers." In Power Religion: The Selling Out of the Evangelical Church?, edited by Michael Scott Horton, 301313. Chicago: Moody Press, 1992.

Michaelis, W. "kratos [power, strength]." In Theological Dictionary of the New Testament, edited by Gerhard Kittel, Gerhard Friedrich, and Geoffrey William Bromiley, xxxvi, 1356. Grand Rapids, MI: W.B. Eerdmans, 1985.

Migliore, Daniel L. The Power of God and the Gods of Power. Louisville, KY: Westminster John Knox Press, 2008.

Moltmann, Jürgen. Experiences in Theology: Ways and Forms of Christian Theology. Translated by Margaret Kohl. Minneapolis, MN: Fortress Press, 2000.

Moon, Jerry. W. C. White and Ellen G. White: The Relationship Between the Prophet and Her Son. Vol. 19, edited by University Andrews and Seminary Seventh-day Adventist Theological. Berrien Springs, MI: Andrews University Press, 1993.

Morre, A. L. "Kingly Power." In The Ellen G. White Encyclopedia, edited by Denis Fortin and Jerry Moon. Hagerstown, MD: Review nad Herald Publishing Association, 2013.

Morris, Thomas V. If Aristotle Ran General Motors: The New Soul of Business. 1st ed. New York: Henry Holt and Co., 1997. 
Mowry, George E. The Era of Theodore Roosevelt, 1900-1912. New York: Harper \& Brothers, 1958.

Neufeld, Don F, ed., Seventh-day Adventist Bible Dictionary. Washington, DC: Review \& Herald, 1979

Niebuhr, H. R. Christ and Culture. New York: Harper Torchbooks, 1975.

Nietzsche, Friedrich. Beyond Good and Evil: Prelude to a Philosophy of the Future. Translated by R. J. Hollingdale. New York: Penguin Books, 1990.

Nietzsche, Friedrich. Thus Spoke Zarathustra: A Book for All and None. Translated by Walter Kaufmann. New York: Penguin Books, 1980.

Niewold, Jack. "Beyond Servant Leadership." Journal of Biblical Perspectives in Leadership 1, no. 2 (2007): 118-134.

Northouse, Peter G. Leadership: Theory and Practice. 4th ed. Thousand Oaks, CA: Sage Publications, 2007.

Northouse, Peter G. Leadership: Theory and Practice. 6th ed. Thousand Oaks, CA: Sage Publications, 2013.

Oliver, Barry D. SDA Organizational Structure: Past, Present, and Future. Vol. XV. Doctoral Dissertation Series. Berrien Springs, MI: Andrews University Press, 1989.

"On the Unique Headship of Christ in the Church." Andrews University Seventh-day Adventist Theological Seminary. Last modified 2014. Accessed January 6, 2016. https://www.andrews.edu/sem/9-19-14-updated_web_versionunique_headship_of_christ_final.pdf.

Outler, Albert Cook, Encyclopedia Britannica: Encyclopedia Britannica Inc., 2016.

Oyen, A. B. "Sixteenth Annual Session of the General Confernce of S. D. Adventists." The Review and Herald vol. 50, no. 14 (October 4, 1877).

Packer, J. I. Freedom, Authority \& Scripture. 1st British ed. Leicester, England: InterVarsity Press, 1982.

Patterson, Stanley E. "The Place of Authority in the Organizational Structure of the Seventh-day Adventist Church." Potomac Conference of Seventh-day Adventist Church. Accessed January 16, 2016. http://www.pcsda.org/wpcontent/uploads/2014/10/The-Place-of-Authority-in-the-SDA-OrganizationalStructure1.pdf. 
Plato. The Republic. Translated by G. R. F. Ferrari and Tom Griffith. Cambridge texts in the history of political thought. Cambridge, NY: Cambridge University Press, 2000 .

Poling, James N. The Abuse of Power: A Theological Problem. Nashville, TN: Abingdon Press, 1991.

"Power." In New Dictionary of Christian Ethics \& Pastoral Theology, edited by David John Atkinson, David Field, Arthur Frank Holmes, and Oliver O'Donovan, xxiii, 918. Downers Grove, IL: InterVarsity Press, 1995.

Ramm, Bernard L. The Pattern of Religious Authority. Grand Rapids, MI: Eerdmans, 1965.

Read, James H. "Is Power Zero-Sum or Variable-Sum? Old Arguments and New Beginnings." Political Science Faculty Publications 3-2012, no. 4 (2012). http://digitalcommons.csbsju.edu/polsci_pubs/4.

Rice, Richard. Reign of God: An Introduction to Christian Theology from a Seventh-day Adventist Perspective. 2nd ed. Berrien Springs, MI: Andrews University Press, 1997.

Robertson, John J. A. G. Daniells: The Making of a General Conference President, 1901. Mountain View, CA: Pacific Press, 1977.

Schwarz, Richard and Floyd Greenleaf. Light Bearers: A History of the Seventh-day Adventist Church. Nampa, ID: Pacific Press, 2000.

Schwarz, Richard and Greenleaf, Floyd. Light Bearers: A History of the Seventh-Day Adventist Church. Rev. ed. Nampa, ID: Pacific Press Publishing Association, 2000.

Schwarz, Richard W. "John Harvey Kellogg: American Health Reformer." Ph. D Dissertation, University of Michigan, 1964.

Schwarz, Richard W. John Harvey Kellog, M.D. - Pioneering Health Reformer. Hagerstown, MD: Review and Herald Publishing Association, 2006.

Schwarz, Richard W. "The Kellogg Schism - The Hidden Issues." Spectrum (Autumn, 1972): 23-39.

Schweiker, William. Power, Value, and Conviction: Theological Ethics in the Postmodern Age. Cleveland, OH: Pilgrim Press, 1998.

Senge, P. M. "Afterword." In Servant Leadership: A Journey Into the Nature of Legitimate Power, edited by R. K. Greenleaf. New York: Paulist Press, 2002. 
Sherman, Stuart P. "Roosevelt and the National Psychology." In Theodore Roosevelt: A Profile, edited by Morton Keller. New York: Hill and Wang, 1967.

Sipe, James W. and Don M. Frick. Seven Pillars of Servant Leadership: Practicing the Wisdom of Leading by Serving. New York: Paulist Press, 2009.

Snodgrass, Klyne R. "You Slaves on Account of Jesus: Servant Leadership in the New Testament." In Servant Leadership: Authority and governance in the Evangelical Free Church, edited by James R. Hawkinson and Robert K. Johnston, vol 1. Chicago: Covenant Publications, 1993.

Søvik, Atle O. The Problem of Evil and the Power of God. Boston: Brill, 2011.

Spears, Larry C. "Tracing the Past, Present, and Future of Servant-Leadership." In Focus on Leadership Servant-Leadership for the Twenty-First Century, edited by Larry C. Spears and Michele Lawrence, xiv, 396. New York: J. Wiley \& Sons, 2002.

Spears, Larry C. and Michele Lawrence. Practicing Servant-Leadership: Succeeding Through Trust, Bravery, and Forgiveness. 1st ed. San Francisco, CA: JosseyBass, 2004.

Standish, Colin D. and Russell R. Standish. Embattled Church. Rapidan, VA: Hartland Publications, 1995.

Starratt, Robert J. Ethical Leadership. Jossey-Bass Leadership Library in Education. San Francisco: Jossey-Bass, 2004.

Stassen, Glen H. and David P. Gushee. Kingdom Ethics: Following Jesus in Contemporary Context. Downers Grove, IL: InterVarsity Press, 2003.

Stortz, Martha E. PastorPower. Nashville, TN: Abingdon Press, 1993.

Taylor, Charles. The Ethics of Authenticity. Cambridge, MA: Harvard University Press, 1992.

"The General Conference Bulletin: Thirty-Fifth Session." The General Conference of Seventh-day Adventist Church, April 6, 1903.

"The General Conference Bulletin: Thirty-Fifth Session." The General Conference of Seventh-day Adventist Church, April 10, 1903.

The General Conference Bulletin: Thirty-Fifth Session. Vol. 5. The General Conference of Seventh-day Adventist Church. Oakland, CA: Pacific Press, 1903.

The General Conference Bulletin: Thirty-Fourth Session. Vol. 4. The General Conference of Seventh-day Adventist Church. Battle Creek, MI: The Seventh-day Adventist General Conference, 1901. 
Theissen, Gerd. "The Ambivalence of Power in Early Christianity." In Power, Powerlessness, and the Divine: New Inquires in the Bible and Theology, edited by Cynthia L. Rigby. Atlanta, GA: Scholars Press, 1997.

Thiroux, Jacques P. Ethics: Theory and Practice. 6th ed. Upper Saddle River, NJ: Prentice Hall, 1998.

Tillich, Paul. Systematic Theology: Existence and The Christ. Vol. 2, 3 vols. Chicago: University of Chicago, 1975.

Twain, Mark. The Adventures of Tom Sawyer. New York: Oxford University Press, 2010.

Valentine, Gilbert M. The Prophet and the Presidents. Nampa, ID: Pacific Press, 2011.

Valentine, Gilbert M. W. W. Prescott: Forgotten Giant of Adventism's Second Generation. Hagerstown, MD: Review and Herald, 2005.

"Virtue." The Westminster Dictionary of Christian Ethics. Edited by James F. Childress and John Macquarrie, xvii, 678 p. Philadelphia: Westminster Press, 1986.

Waggoner, J. H. The Church: Its Organization, Ordinances, and Discipline. Oakland, CA: Pacific Press, 1886.

Waterman, Harold. "Principles of 'Servant Leadership' and How They Can Enhance Practice." Nursing Menagement 17, no. 9 (2011): 24-26.

Watts, Sarah. Rough Rider in the White House: Theodore Roosevelt and the Politics of Desire. Chicago: The University of Chicago Press, 2003.

Weber, Hans-Ruedi. Power: Focus for a Biblical Theology. Geneva, Switzerland: WCC Publications, 1989.

Weber, Max. Economy and Society: An Outline of Interpretive Sociology. Edited by Guenther Roth and Claus Wittich. Berkley, CA: University of California Press, 1978.

Werline, Rodney A. "Prayer, Politics, and Power in the Hebrew Bible." Interpretation: A Journal of Bible and Theology 68, no. 1 (January 2014): 5-12. Accessed October 7, 2015, Academic Search Complete, EBSCOhost.

Wheatley, M. "The Work of Servant Leader." In Focus on Leadership ServantLeadership for the Twenty-First Century, edited by Larry C. Spears and Michele Lawrence, xiv, 396. New York: J. Wiley \& Sons, 2002.

Whidden, Woodrow W. E. J. Waggoner: From the Physician of Good News to the Agent of Division. Hagerstown, MD: Review and Herald, 2008. 
White, Ellen. "A Call to Reconsecrate, Reorganize, and Advance." Manuscript Releases, vol. 13, Silver Spring, MD.

White, Ellen. "A Visit to the South." The Review and Herald, no. 2 (August 18 1904).

White, Ellen. Christ Triumphant: Devotional Meditations on the Great Controversy Story. Hagerstown, MD: Review and Herald 1999.

White, Ellen. Christian Temperance. Battle Creek, MI: Good Health Publishing Company, 1890.

White, Ellen. Conflict \& Courage. Hagerstown, MD: Review and Herald, 2005.

White, Ellen. Counsels On Diet And Foods. Washington, DC: Review and Herald Pub. Association, 1976.

White, Ellen. "Draw from the Source of Strength." The Signs of the Times (October 10th 1892).

White, Ellen. Early Writings of Ellen G. White. Hagerstown, MD: Review and Herald, 2000.

White, Ellen. Ellen White to the Brethren in Battle Creek, 5 January 1903. Berrien Springs, MI: Center for Adventist Research, Andrews University, 1903.

White, Ellen. "General Conference Proceedings." The General Conference Bulletin, Thirty-fourth Session, April 5, 1901.

White, Ellen. "God's Design for His People." The Review and Herald vol. 76, no. 27 (July 4, 1899).

White, Ellen. "Individual Responsibility \& Christian Unity". Manuscript 29, 1907

White, Ellen. "Kingly Power: Verbatim Report of Remarks by Mrs. E. G. White, at a Meeting Held in Battle Creek College Library, April 1, at the General Conference of 1901." Spalding and Magan Collection (1985). Accessed on March 8, 2016. https://m.egwwritings.org/en/book/516.1077\#1078.

White, Ellen. Letter 49, 1903, to A.G. Daniells and his fellow workers. Ellen G. White Estate Branch Office Document File, 1903.

White, Ellen. "Letter of Ellen White to J. Arthur, Jan. 14, 1903." In Manuscript Releases, vol. 13. Silver Springs, MD: E. G. White Estate, 1993.

White, Ellen. Manuscript Releases: From the Files of the Letters and Manuscripts. Vol. 2. Washington, DC: E. G. White Estate, 1987.

White, Ellen. Manuscript Releases: From the Files of the Letters and Manuscripts. Vol. 4. Washington, DC: E. G. White Estate, 1990. 
White, Ellen. Manuscript Releases: From the Files of the Letters and Manuscripts. Vol. 8. Washington, DC: E. G. White Estate, 1990.

White, Ellen. My Life Today: The Morning Watch Texts with Appropriate Selections from the Writings of Ellen G. White. Washington, DC: Review and Herald, 1952.

White, Ellen. No Kingly Power. Letter 212, 1903. (September 23, 1903, written To the Teachers in Emmanuel Missionary College.)

White, Ellen. "Opening Remarks." The General Conference Bulletin, Thirty-fourth Session, April 3, 1901.

White, Ellen. Patriarchs and Prophets. Oakland, CA: Pacific Press, 1890.

White, Ellen. Redemption, or, The Teachings of Christ, the Anointed One. Life of Christ. Battle Creek, MI: Steam Press of the Seventh-day Adventist Publishing Association, 1877.

White, Ellen. Sermon: A Plea for Unity. Letters and Manuscripts, Berrien Springs, MI.

White, Ellen. Spiritual Gifts. Vol. 1. Battle Creek, MI: Steam Press of the Seventh-day Adventist Publishing Association, 1858.

White, Ellen. "Tempted in All Points Like as We Are." Bible Echo and Signs of the Times vol. 7, no. 21 (November 1st 1892): 322.

White, Ellen. Testimonies for the Church. Vol. 2. Boise, ID: Pacific Press, 1948.

White, Ellen. Testimonies for the Church. Vol. 3. Nampa, ID: Pacific Press, 2002.

White, Ellen. Testimonies for the Church. Vol. 5. Nampa, ID: Pacific Press, 2002.

White, Ellen. Testimonies for the Church. Vol. 8. Nampa, ID: Pacific Press, 2002.

White, Ellen. Testimonies for the Church. Vol. 9. Nampa, ID: Pacific Press, 2002.

White, Ellen. Testimonies to Ministers And Gospel Workers: Selected From Special Testimonies to Ministers And Workers. Mountain View, CA: Pacific Press, 1962.

White, Ellen. The Desire of Ages. Nampa, ID: Pacific Press, 2005.

White, Ellen. The Ministry of Healing. Mountain View, CA: Pacific Press 1905.

White, Ellen G. Education. Nampa, ID: Pacific Press, 2002.

White, James. "Doings of the Battle Creek Conference, Acts 5:16, 1861." The Review and Herald vol. 18, no. 19 (8 October 1861): 148-149. 
White, James. "Eight Weeks at Battle Creek." The Review and Herald vol. 47, no. 22 (June 1, 1876).

White, William Allen. "Theodore Roosevelt." In Theodore Roosevelt: A Profile, edited by Morton Keller. New York: Hill and Wang, 1967.

Wiggam, A. E. "The Most Remarkable Man I Have Ever Known." American Magazine, December, 1925.

Wilson, Brian C. Dr. John Harvey Kellogg and the Religion of Biologic Living. Bloomington, IN: Indiana University Press, 2014.

Wong, Paul T. P. and Dean Davey, "Best Practices in Servant Leadership." Servant Leadership Research Roundtable, July 2007.

Wright, Christopher J. H. Old Testament Ethics for the People of God. Downers Grove, IL: InterVarsity Press, 2004.

\section{Unpublished Documents}

Baker, A. L., to P. T. Magan, November 8, 1939. Magan Papers.

Daniells, A. G., to Brother Starr, January 10, 1990. Ellen G. White Estate.

Kellogg, J. H., to W. C. White, April 12, 1875. E. G. White Papers.

Kellogg, J. H., to G. I. Butler, December 21, 1902. MSU Kellogg Papers.

Kellogg, J. H., to S. N. Haskell, June 18, 1905. MSU Kellogg Papers.

Dr. Lindsay, W. T., to R. W. Schwarz, May 23, 1961. As quoted in: Schwarz, Richard W. "John Harvey Kellogg: American Health Reformer." Ph.D Dissertation, University of Michigan, 1964.

MS account of the events connected with Dr. Kellogg's sixtieth birthday celebration, February 26, 1912. RBF Kellogg Papers.

White, Ellen G., to A. G. Daniels, April 12,1903. Ellen G. White Estate.

White, W. C., to A. G. Daniells, June 20, 1910. Ellen G. White Estate Branch Office Document File.

White, Ellen G., to G. I. Butler, October 14, 1888. Ellen G. White Estate Branch Office Document File.

White, Ellen G., to J. H. Kellogg, April 26, 1886. Ellen G. White Estate Branch Office Document File. 
White, Ellen G., to J. H. Kellogg, January 5, 1899. Ellen G. White Estate Branch Office Document File.

White, Ellen G., to O. A. Olsen, September 19, 1895. Ellen G. White Estate Branch Office Document File.

White, Ellen, G., to O. A. Olsen, October 28, 1885. Ellen G. White Estate Branch Office Document File. 
VITA

Zorislav Plantak, 4675 Timberland Dr. Berrien Springs, MI 49103

\section{Education}

$B A$ in Religion, Adriatic Union College, Marusevec, Croatia, 1986.

MA in Religion, Andrews University, 2003.

PhD in Religion, Andrews University, Christian Ethics; Cognate: Adventist History 2018

\section{Professional Experience}

Teacher, Consortium of Adventist Colleges \& Universities, 2014-2015.

Classes: Religion and Ethics in Modern Society, Personal Evangelism, Homiletics, and Introduction to Pastoral Ministry.

Substitute Teacher, Ethics; Andrews University, 2009-2015.

Teacher, Computer Based Text Editing; Adriatic Union College, Croatia, 1993-1995.

Ordained Sevent-day AdventistMinister from 1995

Senior Pastor, Elk Grove Village Seventh-day Adventist Church, August 2009 - Present.

Senior Pastor, Croatian Conference of Seventh-day Adventist, 1995 - 2000.

Associate Pastor, Croatian Conference of Seventh-day Adventist, Church District:

Zagreb 1, 1986-1988.

\section{Presentations}

Zorislav Plantak (May, 2014). Kingly Power" in the 1901 and 1903 Sessions of the General Conference of the Seventh-Day Adventist Church and its Effects on the Development of the Adventist Doctrine of the Church. Paper presented at the symposium of the Adventist Theological Society's at Southern Adventist University.

Zorislav Plantak, (November, 2016) Abuses of Power in the Church of My Dreams: The Moral and Practical Lessons From the "Kingly Power" Issue in the Seventh-day Adventist Church. Paper presented at the annual meeting of the Adventist Society for Religious Studies at San Antonio, TX.

\section{Affiliations}

Adventist Society for Religious Studies (ASRS)

Adventist Theological Society (ATS)

Evangelical Theological Society (ETS)

Society of Biblical Literature (SBL) 


\section{Honors}

De Haan Award for Excellence in Work, Andrews University, 2002 